UNIVERSIDADE DE SÃO PAULO

ESCOLA DE ENFERMAGEM

\title{
O TRABALHO COMO ESTRATÉGIA DE DESINSTITUCIONALIZAÇÃO E EMANCIPAÇÃO NA SAÚDE MENTAL.
}

\author{
Paula Urzúa Taleikis
}

Orientadora: $\operatorname{Prof}^{\mathrm{a}} \mathrm{Dr}^{\mathrm{a}}$ Sônia Barros

SÃO PAULO

2009 
PAULA URZÚA TALEIKIS

\section{O TRABALHO COMO ESTRATÉGIA DE DESINSTITUCIONALIZAÇÃO E EMANCIPAÇÃO NA SAÚDE MENTAL.}

Dissertação apresentada à Escola de Enfermagem da Universidade de São Paulo para obtenção do titulo de Mestre em Enfermagem.

Área de concentração: Enfermagem Psiquiátrica.

Orientadora: $\operatorname{Prof}^{\mathrm{a}} \mathrm{Dr}^{\mathrm{a}}$ Sônia Barros

SÃO PAULO

2009 


\section{AUTORIZO A REPRODUÇÃO TOTAL OU PARCIAL DESTE TRABALHO, POR QUALQUER MEIO CONVENCIONAL OU ELETRÔNICO, PARA FINS DE ESTUDO E PESQUISA, DESDE QUE CITADA A FONTE.}

Assinatura:

Data:

Catalogação na Publicação (CIP)

Biblioteca "Wanda de Aguiar Horta"

Escola de Enfermagem da Universidade de São Paulo

Taleikis, Paula Urzúa.

O trabalho como estratégia de desinstitucionalização e emancipação / Paula Urzúa Taleikis. - São Paulo, 2009. $281 \mathrm{p}$.

Dissertação (Mestrado) - Escola de Enfermagem da Universidade de São Paulo.

Orientadora: $\operatorname{Prof}^{\mathrm{a}}$ Dr $^{\mathrm{a}}$ Sonia Barros.

1. Reabilitação vocacional 2. Desinstitucionalização 3. Saúde mental. I. Título. 
Nome: Paula Urzúa Taleikis

Título: O trabalho como estratégia de desinstitucionalização e emancipação na Saúde Mental.

Dissertação apresentada à Escola de Enfermagem da Universidade de São Paulo para obtenção do titulo de Mestre em Enfermagem.

Aprovado em:

\section{Banca Examinadora}

Prof. Dr. Instituição:

Julgamento Assinatura:

Prof. Dr. Instituição:

Julgamento Assinatura:

Prof. Dr. Instituição:

Julgamento Assinatura: 


\title{
Dedicatória
}

\author{
"A los muertos que alumbran los caminos", \\ Marx, Basaglia, Machel, Guevara, Neruda e Victor Jara, \\ Grandes Mestres que ousaram transgredir a ordem.
}

Ao meu querido Mauro Iasi, companheiro de sonhos e militâncias.

\begin{abstract}
À minha adorável família, Verônica, Casemiro, Mauricio, Carolina, Fernando e Adriana, incansáveis lutadores pelo futuro respirável.
\end{abstract}




\section{Agradecimentos}

Agradeço primeiramente à minha amiga-irmã Paula Pinho, companheira solidária e dedicada de todas as horas da especialização e do mestrado com quem compartilho a paixão pela saúde mental.

Agradeço honrosamente à minha orientadora $\operatorname{Prof}^{\mathrm{a}} \mathrm{Dr}^{\mathrm{a}}$ Sônia Barros, que pacientemente enriqueceu-me com seu conhecimento e sabedoria.

Agradeço especialmente à $\operatorname{Prof}^{\mathrm{a}} \mathrm{Dr}^{\mathrm{a}}$ Márcia Oliveira, pela sua enorme gentileza e solidariedade, que estimulou e cooperou com mais esse estudo.

Agradeço gentilmente às $\operatorname{Prof}^{\mathrm{as}} \operatorname{Dr}^{\text {as }}$ Ana Luisa de Sousa Aranha e Maria Fernanda Nicácio pelas contribuições no exame de qualificação.

Agradeço enormemente à minha psicóloga Zilá Chamon, que me encorajou a empreender e prosseguir em mais este projeto de vida.

Agradeço carinhosamente ao meu amigo Décio de Castro Alves, que possibilitou a realização deste projeto de várias maneiras.

Agradeço especialmente aos amigos Luciana, Débora, Vera, Eraldo, Sebá e Dirce pelos momentos prazerosos de trocas, reflexões e aprendizado.

Agradeço a todos os profissionais e usuários que conheci ao longo desse caminhar, que me ensinaram o prazer do trabalho coletivo e a beleza e complexidade da vida.

Agradeço aos meus queridos amigos do Canto Libre e camaradas do $P C B$, que carinhosamente me apoiaram e compreenderam minhas ausências.

Agradeço a todos os professores, funcionários e alunos da pósgraduação da EEUSP, que gentilmente possibilitaram este estudo com suas contribuições teóricas e práticas.

Agradeço enormemente à Cleusa, Heloísa e a equipe do NOT pela sua gentileza em colaborar com este estudo, que espero humildemente possa servir de contribuição à reflexão e execução daquele importante trabalho. 
Lento mas vem

O futuro se aproxima

Devagar

Mas vem

Já vem se aproximando

Nunca tem pressa

Vem com projetos

E bolsas de sementes

Com anjos maltratados

E fiéis andorinhas

Devagar mas vem

Sem fazer muito ruído

Cuidando sobretudo

Dos sonhos proibidos

Das lembranças jacentes

Y das recém nascidas

Lento mas vem

O futuro se aproxima Devagar

Mas vem

Já está quase chegando Com sua melhor noticia Com punhos com olheiras

com noites e com dias

Como uma estrela pobre

sem nome ainda

Lento mas vem

O futuro real

o mesmo que inventamos

Nós e o azar

Cada vez mais nós

Cada vez menos o azar

Lento mas vem

o futuro se aproxima Devagar

Mas vem

Lento mas vem

Lento mas vem

Mario Benedetti 
Taleikis, PU. O trabalho como estratégia de desinstitucionalização e emancipação na saúde mental [dissertação]. São Paulo (SP): Escola de Enfermagem, Universidade de São Paulo; 2009. 281 pags.

\section{RESUMO}

Este estudo tem por finalidade contribuir com a reflexão sobre a utilização do trabalho nas propostas reabilitadoras de desinstitucionalização no contexto da Reforma Psiquiátrica Brasileira, buscando compreender o sentido do trabalho e algumas concepções que norteiam as experiências de trabalho no campo da saúde mental. O objeto desta pesquisa, portanto, são as oficinas de trabalho que se orientam pelo trabalho cooperado, entendidas como uma possibilidade de subverter a lógica excludente e normatizadora da relação trabalho e saúde mental que historicamente pautou a relação sociedade/loucura e as instituições (assistenciais, jurídicas, sociais, culturais) que imbuídas dessa lógica vitimaram as pessoas com sofrimento mental, culminando com variados tipos de violência e desumanização. Para compreender esse processo de transformações complexo, fundamentamos o estudo na abordagem dialética, uma vez que possibilita buscar a essência do trabalho a partir da sua expressão na aparência, entendendo como algo em permanente movimento dialético, carregado de conflitos e contradições. Para os autores dessa abordagem o trabalho é considerado um elemento central da realidade, mas deve ser compreendido como historicamente determinado e somente a partir da sua totalidade pode se compreender sua forma particular, nesta pesquisa, nas oficinas de trabalho de um serviço de saúde mental criado no bojo do processo de reforma psiquiátrica de Campinas. Também utilizamos os conceitos de desinstitucionalização, reabilitação psicossocial e cooperativismo social, buscando articulá-los com a categoria analítica Trabalho e suas expressões (alienação, emancipação e processo de trabalho) na concepção marxista, que balizam a análise dos dados. A coleta dos dados foi realizada essencialmente por meio de entrevistas semi-estruturadas com a gerente e os coordenadores das oficinas de trabalho. Os dados foram submetidos à análise temática dando origem as categorias empíricas: projeto institucional, modo de estruturação do serviço, processo de trabalho em saúde e concepções sobre reabilitação 
psicossocial, trabalho e cooperativismo social. A análise revelou a existência de contradições e conflitos, que refletem especialmente os modelos tecnoassistenciais em disputa, que por sua vez, são determinados pela totalidade, pelos interesses opostos da luta de classes na sociedade, especialmente sobre os processos de trabalho que pretendem mudanças concretas na vida dos usuários no sentido da sua emancipação. Apontamos para a necessidade de subverter a lógica do trabalho terapêutico, dependente e alienado para transformar a produção e reprodução material e subjetiva dos sujeitos protagonistas dessas mudanças, usuários, familiares e trabalhadores em saúde mental, que passa necessariamente pela conscientização de todos sobre os mecanismos de opressão e dominação manifestos ou latentes ainda presentes nas relações sociais, desde as mais singulares até o âmbito estrutural.

DESCRITORES: saúde mental, desinstitucionalização, reabilitação vocacional, trabalho. 
Taleikis, PU. El trabajo como estrategia de des-institucionalización y emancipación en la salud mental [disertación]. São Paulo (SP): Escuela de Enfermería, Universidad de São Paulo; 2009. 281 pags.

\section{RESUMEN}

Este estudio tiene como finalidad contribuir con la reflexión sobre la utilización del trabajo en las propuestas rehabilitadoras de desinstitucionalización en el contexto de la Reforma Psiquiátrica Brasileña, procurando comprender el sentido del trabajo y algunas concepciones que nortean las experiencias de trabajo en el campo de la salud mental. El objeto de esta pesquisa, por lo tanto, son los talleres de trabajo que se orientan por el trabajo cooperado, entendidos como una posibilidad de subvertir la lógica excluyente y normalizadora de la relación trabajo y salud mental que históricamente pautó la relación sociedad-locura y las instituciones (asistenciales, jurídicas, sociales, culturales) que, imbuidas de esa lógica, perjudicaron a las personas con sufrimiento mental, culminando con variados tipos de violencia y deshumanización. Para comprender este complejo proceso de transformaciones, fundamentamos el estudio en el abordaje dialéctico, ya que torna posible buscar la esencia del trabajo a partir de su expresión en la apariencia, entendiendo como algo en permanente movimiento dialéctico, cargado de conflictos y contradicciones. Para los autores de este abordaje, el trabajo es considerado un elemento central de la realidad, pero debe ser comprendido como históricamente determinado, y es solamente a partir de su totalidad que se puede comprender su forma particular, en el caso de esta pesquisa, en los talleres de trabajo de un servicio de salud mental creado en la médula del proceso de reforma psiquiátrica de Campinas. También utilizamos los conceptos de desinstitucionalización, rehabilitación psicosocial y cooperativismo social, buscando articularlos con la categoría analítica Trabajo y sus expresiones (alienación, emancipación y proceso de trabajo) en la concepción marxista, que guían el análisis de los datos. La recolección de los datos fue realizada esencialmente por medio de entrevistas semiestructuradas con la gerente y los coordinadores de los talleres de trabajo. Los datos fueron sometidos a análisis temática, dando origen a las categorías empíricas: proyecto 
institucional, modo de estructuración del servicio, proceso de trabajo en salud, y concepciones sobre rehabilitación psicosocial, trabajo y cooperativismo social. El análisis reveló la existencia de contradicciones y conflictos, que reflejan especialmente los modelos tecno-asistenciales en disputa, que por su vez, son determinados por la totalidad, por los intereses opuestos de la lucha de clases en la sociedad, especialmente sobre los procesos de trabajo que pretenden mudanzas concretas en la vida de los usuarios en el sentido de su emancipación. Apuntamos hacia la necesidad de subvertir la lógica del trabajo terapéutico, dependiente y alienado, para transformar la producción y reproducción material y subjetiva de los sujetos protagonistas de estas mudanzas, usuarios, familiares y trabajadores en salud mental, que pasa necesariamente por la concientización de todos sobre los mecanismos de opresión y dominación, manifestados o latentes, todavía presentes en las relaciones sociales, desde las más singulares hasta el ámbito estructural.

DESCRIPTORES: salud mental, des-institucionalización, rehabilitación vocacional, trabajo. 
Taleikis, PU. Work as strategy of deinstitutionalization and emancipation in mental health [dissertation]. Sao Paulo (SP): Nursing School, University of Sao Paulo; 2009. 281 pages.

\section{ABSTRACT}

This study has as the main objective to contribute to the reflection about the use of labor in the rehabilitative proposition of deinstitutionalization in the context of the Brazilian Psychiatric Reform, looking for the understanding of the meaning of work and some conceptions that guide the experiences of work in the field of mental health. Therefore, the object of this research are the workshops that are guided by the cooperative work, understood as a possibility to subvert the excluding and normative logic of the relation of work and mental health that ruled historically the relation society/madness and the institutions (assistant, juridical, social, cultural) that imbued of this logic victimized people with mental distress, culminated with several kinds of violence and dehumanization. To understand this process of complex transformation, we substantiated the study with the dialectical approach, once it makes possible the search for the essence of work by its expression in aspect, understanding it as something in permanent dialectical movement, carried of conflicts and contradictions. For the authors of this approach, work is considered as a central element of reality, but it must be understood as historically determined and only by its totality we can understand its particular form, in this research, at the workshops of a mental health assistance created in the middle of the process of the psychiatric reform of Campinas. We also used the concepts of deinstitutionalization, psychosocial rehabilitation and social cooperativeness, seeking to articulate them with the analytical category of Work and its expressions (alienation, emancipation and working process) by the light of the Marxist conception, that delimitate the data analysis. The data collection was carried out essentially by semistructured interviews with the manager and the coordinators of the workshops. The data were submitted to the thematic analysis originating the following empirical categories: institutional project, structuring mode of the service, process of working in mental health and conceptions about psychosocial rehabilitation, work and social cooperativeness. The analysis 
revealed the existence of contradictions and conflicts that reflect especially the techno-assistant models in dispute, that in their turn, are determined by totality, by the opposite interests of the class struggle in society, especially about the processes of work that intend concrete changes in the life of the users on their emancipation. We pointed out the need of subversion of the logic of the dependant and alienated therapeutic work to transform the material and subjective production and reproduction of the subjects protagonists of these changes, users, familiars and workers in metal health, who necessarily go through the consciousness of everyone about the evident or latent mechanisms of oppression and domination still present in social relations, from the most singular to the structural ones.

KEY-WORDS: Mental Health, Deinstitutionalization, Vocational Rehabilitation, Work. 


\section{SUMÁRIO}

APRESENTAÇÃO

I. INTRODUÇÃO 21

1. O nascimento da Psiquiatria e sua relação com o mundo do trabalho 23

2. A centralidade do trabalho na instituição psiquiátrica: o tratamento moral 27

3. Reformas Psiquiátricas e Reabilitação Psicossocial no eixo trabalho 38

II. PERCURSO METODOLÓGICO 53

1. Referencial teórico metodológico e categorias de análise 54

1.1 O Trabalho como Categoria Analítica 58

a. Alienação $\quad 62$

b. Emancipação Humana 64

c. Processo de Trabalho 65

1.2.Operacionalização de outros conceitos $\quad 66$

a. Desinstitucionalização como Emancipação 67

b. Reabilitação Psicossocial como Cidadania 68

c. Cooperativismo Social 69

2. Percurso Exploratório $\quad 71$

2.1. Cenário da Pesquisa 71

2.2. Fonte de Dados Empíricos $\quad 80$

2.3. Procedimentos para Coleta e Análise dos Dados 80

III. ANÁLISE DOS RESULTADOS $\quad 86$

1. NOT: Projeto Institucional e Reforma Psiquiátrica 87

2. Modo de Estruturação do Serviço 109

2.1.Acesso 110

2.2. Adesão 121

2.3. Desligamento (Saída) 128

3. Processo de Trabalho em Saúde 139

3.1. Agente Principal do Trabalho em Saúde: a equipe de 148

Coordenadores

3.2. Objeto de Trabalho em Saúde: Oficineiros do NOT 153

3.3. Instrumentos: Atenção Psicossocial e Processo de Produção 156

3.4. Parcelamento do Trabalho: os agentes e a divisão do trabalho 164

3.5. Organização do Trabalho nas Oficinas 172

3.6. Finalidade do Processo de Trabalho nas Oficinas 181

3.7. Finalidade do Processo de Trabalho em Saúde 184

3.8. Dificuldades e Possibilidades: contradições a serem superadas 194

4. Concepção de Reabilitação Psicossocial, Trabalho e 202

Cooperativismo Social

4.1. Reabilitação Psicossocial 202

4.1.1. Reabilitação Psicossocial como Adaptação Social 205

4.1.2. Reabilitação Psicossocial como Cidadania 215

4.2. Trabalho e Desinstitucionalização 224

4.2.1. Trabalho Normatizador (alienado) 225

4.2.2. Trabalho Reabilitador (emancipado) 231

4.3. Cooperativismo Social: Trabalho e Desinstitucionalização 236

IV. CONSIDERAÇÕES FINAIS 250

V. REFERÊNCIAS BIBLIOGRÁFICAS 263

$\begin{array}{ll}\text { VI. ANEXOS E APENDICE } & 274\end{array}$ 
APRESENTAÇÃO 


\section{APRESENTAÇÃO}

"A história só existe como história feita pelos homens, e estes só existem produzindo uma nova realidade com sua práxis produtiva $e$ produzindo-se a si mesmos em um processo que não tem fim; isto é, os homens transformam e se transformam a si mesmos e essa história de suas transformações é propriamente sua verdadeira história."

Adolfo Sánchez Vásquez. Filosofia da

práxis.

Devido à minha atuação profissional num Centro de Atenção Psicossocial (CAPS) ${ }^{1}$, iniciei a especialização em saúde mental na Escola de Enfermagem da USP, quando pude sistematizar meus estudos na área e conhecer outros atores e experiências do campo psicossocial e da chamada Reforma Psiquiátrica Brasileira².

Nessa trajetória no campo da assistência pública à saúde mental, tentando constituir uma práxis transformadora para a vida dos usuários e seus familiares, tornava-se imperativo o envolvimento de outros setores na discussão de uma nova relação com a loucura que não fosse marcada pela estigmatização e exclusão social. Durante as conversas com os usuários, tentando restituir sua subjetividade a partir da reconstituição de recursos materiais, sociais e culturais (Rotelli, 1982), sentíamos a angústia e o sofrimento deles relacionados ao estigma do doente mental, considerado inútil, desqualificado para o trabalho e consequentemente desvalorizado socialmente. Muitos deles já haviam trabalhado formal ou informalmente e o afastamento dessa atividade era causador de sofrimentos e perdas ainda maiores. Quase todos tinham sonhos em voltar ou começar a trabalhar, seja para ter uma renda que lhes permitisse sobreviver com um mínimo de dignidade seja para sentir-se útil e respeitável para a sua família e comunidade. Como transpor o estigma que condena a loucura ao abandono e à exclusão social era a questão que sempre se colocava.

\footnotetext{
${ }^{1}$ A sigla CAPS foi criada pelos pacientes do Centro de Atenção Psicossocial Prof. Luiz da Rocha Cerqueira em 1987. (Goldberg, 2001)

${ }^{2}$ Dentre os vários expoentes, utilizamos primordialmente os autores Amarante (1992, 1995, 1996, 2007), Aranha e Silva (1997, 2005), Bezerra (1992, 1994), Birman (1992), Barros D (1991, 1994), Barros S (2000, 2001), Delgado J (1991), Delgado PG (1992), Leal (2004), Mângia (2002, 2003), Nicácio (1990, 2003), Rezende (1987), Silva Filho (1987, 2000), Pitta (2001), entre outros.
} 
A vivência nesses serviços com as equipes, com os usuários e seus familiares, e também as aulas e estudos da especialização motivaram o aprofundamento sobre a relação entre saúde mental e trabalho e de ambos com a estrutura social. As leituras das obras de Foucault, Castel, Basaglia, Rotelli, Saraceno, Amarante, Birman, Nicácio, Barros, entre outros, articuladas com as leituras sobre a economia política de Marx e outros autores materialistas dialéticos (lasi, Antunes, Lessa), instigaram o desenvolvimento de uma monografia ${ }^{3}$ sobre o tema da inserção laborativa na saúde mental a partir das experiências de projetos e oficinas de geração de renda e trabalho, de cooperativas ou empresas sociais, no contexto da desinstitucionalização.

O objetivo da monografia foi realizar uma pesquisa bibliográfica da produção científica, no período de 1995 a 2006, acerca dos projetos de inserção laborativa no campo da saúde mental, buscando identificar a natureza da reabilitação psicossocial no eixo trabalho, seja como recurso terapêutico ou como estratégia de inclusão social (Nascimento, Pinho,Taleikis, 2006).

Partindo do pressuposto de que estas experiências, pelo formato ou pelo conteúdo, poderiam reproduzir a natureza terapêutica, exploradora ou alienante da utilização do trabalho na saúde mental, visando o controle social, realizamos o levantamento bibliográfico, no qual verificamos dificuldades em encontrar experiências registradas e nos registros, em forma de panfletos ou documentos, por vezes não havia conteúdo do qual se pudesse identificar a concepção de Reabilitação Psicossocial.

Analisando qualitativamente os resultados encontramos uma concentração maior no campo da saúde mental da temática relativa às Oficinas Terapêuticas, entendidas como dispositivos clínicos e terapêuticos fundamentais à proposta de desinstitucionalização no que se refere à utilização do trabalho como produtor de novos sentidos no âmbito da singularidade, da subjetividade e da cidadania. Poucas publicações, embora

\footnotetext{
${ }^{3}$ Monografia apresentada ao término do IV Curso de Especialização em Saúde Mental promovido pela Escola de Enfermagem da Universidade de São Paulo, em parceria com o Ministério da Saúde, de título Projetos de Inserção Laborativa em Saúde Mental: uma análise da produção científica de 1995 a 2006.
} 
considerem a cooperativa social como uma estratégia importante, aprofundam as possibilidades e limites quanto à sua utilização no campo da saúde mental. É no contexto da Economia Solidária que essa estratégia tem sido amplamente estudada a partir de seus princípios como ajuda mútua, cooperação e educação e viabilizada no desenvolvimento de formas alternativas de produção e consumo destinadas às pessoas em desvantagem social, embora todas as publicações apontem à dificuldade legislativa a ser superada.

Em linhas gerais, o resultado do estudo citado nos permitiu inferir as dificuldades e obstáculos na construção de iniciativas de reabilitação psicossocial no eixo trabalho, não apenas em conseqüência de questões de natureza prática, tal como precariedade de recursos materiais e humanos, mas também da falta de clareza que ainda permeia o cenário da Reforma Psiquiátrica no sentido da construção de estratégias desinstitucionalizantes e emancipadoras a partir do trabalho.

Ainda, como resultado da pesquisa, encontramos uma variação de objetivos das estratégias reabilitadoras de acordo com seu formato, seja como oficina (terapêutica ou de geração de renda), projeto de trabalho, ou na forma de cooperativa ou empresa social. Essa variação se expressa também no sentido mesmo da utilização do trabalho que se apresenta com um caráter terapêutico ou clínico numa vertente bio-psico-social, como produção de mercadorias comercializáveis, como exploração de mão-deobra de baixo custo pela oferta de serviços terceirizados na forma de cooperativas, como meio de vida apenas (geração de renda) ou como mercadoria, no trabalho alienado. Todas essas expressões não pretendem transpor os limites das relações de produção capitalista e da divisão social do trabalho, que produz alienação, a exploração e exclusão social; no máximo se colocam como alternativas à inclusão de pessoas em desvantagem social, mas que aparentemente buscam minimizar e controlar os efeitos da exclusão promovida pelo sistema atual.

As cooperativas sociais também podem se apresentar com um duplo caráter, reformista ou transformador, conforme seus objetivos aparentes ou latentes, mas esta estratégia embora historicamente anterior, no campo da 
saúde mental brasileira não se configura em ações concretas como recurso de reabilitação psicossocial.

Tal estudo possibilitou um contato com a produção acadêmica sobre os projetos de geração de renda e trabalho, e consequentemente, gerou um interesse ainda maior pelo tema da relação entre saúde mental e trabalho, especialmente no que tange às possibilidades e dificuldades na criação de cooperativas sociais no campo da Reforma Psiquiátrica Brasileira. Essa problemática nos motivou a aprofundar os estudos sobre os saberes $\mathrm{e}$ práticas em desenvolvimento no âmbito de um curso de Mestrado. 
INTRODUÇÃO 


\section{INTRODUÇÃO}

A atividade teórica é o processo que, partindo da prática, nos leva a apreender a realidade objetiva para, em seguida, aplicar o conhecimento adquirido na prática social, para transformá-la (Andery, 1989).

No contexto da Reforma Psiquiátrica muito se tem discutido sobre a práxis da Reabilitação Psicossocial ${ }^{4}$, considerada como uma estratégia efetiva para a mudança do paradigma psiquiátrico e da assistência em saúde mental tendo como objetivo a transformação da vida dos usuários a partir do processo de desinstitucionalização. Inúmeras experiências desenvolvidas ao longo desse processo possibilitaram uma mudança na maneira de perceber a loucura e na forma de relacionar-se como esse fenômeno tão complexo da natureza humana.

O grande desafio nesse caminho é subverter o processo de exclusão que a partir da história moderna submeteu não apenas os loucos, mas todos aqueles que foram impossibilitados de vender sua força de trabalho, sendo marginalizados à beira da sociedade, sem direitos, sem recursos materiais ou meios para sobreviver que senão a parca assistência oferecida pelo Estado, ora mais benevolente ora mais implacável com todo o tipo de pobreza.

No campo próprio da saúde mental, determinado também pela estrutura geral da sociedade, a expressão da loucura foi caracterizada pela segregação e estigmatização provenientes das dificuldades que os sujeitos em sofrimento mental tiveram de se inserir no mercado ou de lá permanecer. A valoração da loucura, portanto, foi carregada de uma negatividade dada pelos estatutos da incapacidade e da periculosidade. Entretanto o que se observa ao longo dessa história é que, esse julgamento de improdutividade e de desintegração social era paradoxal, pois em toda a história da psiquiatria e de suas terapêuticas, o trabalho ocupou lugar central dentro e fora das instituições. E os loucos trabalhavam, seja para ocupar-se e não dar vazão aos seus comportamentos inadequados, seja para curar-se, seja para

\footnotetext{
${ }^{4}$ Sobre esse assunto, ver Goldberg (2001), Saraceno (2001), Silva Júnior (2000) Pitta (2001), Tikanori (2001).
} 
explorar sua mão-de-obra. A utilização do trabalho nas instituições psiquiátricas, portanto, não configura uma novidade, aliás, ela está profundamente imbricada ao nascimento da própria psiquiatria, sendo anterior ao surgimento desse ramo da medicina. Podemos afirmar que as transformações das relações de produção que alteraram a vida humana a partir do capitalismo levaram ao nascimento desse ramo da medicina e de sua função: o controle social para manutenção da ordem (Basaglia,1971).

Portanto, quando nos propomos a discutir a utilização do trabalho como meio de inclusão social dos usuários no sentido da cidadania ou emancipação, não podemos esquecer que o trabalho, ao longo da história, manifestou-se de variadas formas e conteúdos, desde o trabalho como mediação de primeira ordem entre o ser humano e a natureza até a forma mercadoria (trabalho abstrato, alienado e assalariado) que conhecemos atualmente, e que não é, de maneira alguma, uma concepção nem natural nem definitiva. Para os marxistas, a forma particular do trabalho no capitalismo se caracteriza pela alienação e pela exploração, que reproduz o sistema excludente e a desigualdade social. O modo de produção capitalista pressupõe o trabalho alienado, a transformação do trabalho humano em mercadoria, a divisão social do trabalho e a exploração da força de trabalho pelo capital.

Diante disso, nos perguntamos: seria essa forma particular de trabalho adequada aos pressupostos da Reforma Psiquiátrica, no sentido da desinstitucionalização e da reabilitação psicossocial? $O$ trabalho nas cooperativas sociais pode se constituir numa opção de trabalho reabilitadoremancipador no campo da saúde mental?

Em outras palavras, seria a forma de trabalho concebido pelo cooperativismo social (trabalho cooperado) uma opção de trabalho adequada aos pressupostos da Reforma Psiquiátrica, no sentido da desinstitucionalização e da Reabilitação Psicossocial cujo horizonte é a emancipação dos usuários?

Para responder tais inquietações, evidentemente sem a pretensão de esgotá-las, mas de problematizá-las, é que nos dirigimos ao estudo teórico da utilização do trabalho cooperado nos projetos de geração de renda e 
trabalho como estratégias de reabilitação psicossocial no contexto da desinstitucionalização a partir da pesquisa das experiências concretas desenvolvidas pela Reforma Psiquiátrica Brasileira. Tomando como referencial teórico a abordagem dialética marxista, buscamos em primeiro lugar compreender a trajetória da psiquiatria em sua relação com o mundo do trabalho. Ao longo dessa história, estudada por autores como Foucault e Castel, consideramos a utilização do trabalho no tratamento moral e sua influência marcante na história da assistência à saúde mental no mundo e no Brasil. Para finalmente, chegarmos às experiências de reformas psiquiátricas e suas concepções acerca da utilização do trabalho na estratégia de reabilitação psicossocial, de onde retiraremos nosso objeto de estudo: as experiências de projetos de geração de renda e trabalho no contexto da Reforma Psiquiátrica no Brasil.

Para a revisão da literatura, foram levantadas as publicações da área contidas em catálogos de livros e outro tipo de publicações científicas, sobretudo as bases de dados Literatura Latino-Americana e do Caribe em Ciências da Saúde (LILACS), Banco de Dados da Universidade de São Paulo (DEDALUS), BIREME/OPAS/OMS, Banco de Teses do Portal da Coordenadoria de Aperfeiçoamento Profissional do Ensino Superior (CAPES), Portal do Ministério da Saúde, Portal da Prefeitura do Município de Campinas e Portal do Serviço de Saúde Dr. Cândido Ferreira, utilizando os seguintes descritores e palavras chaves: saúde mental, psiquiatria, reforma psiquiátrica, reabilitação psicossocial, reabilitação psiquiátrica, cooperativa, cooperativismo, cooperativa social e cooperativismo social, desinstitucionalização, projeto e oficina de trabalho, tratamento moral. Também foram consultadas as referências bibliográficas citadas nas publicações.

\section{O nascimento da Psiquiatria e sua relação com o mundo do trabalho}

$\mathrm{Na}$ revisão de literatura podemos compreender que a relação entre a psiquiatria e o mundo do trabalho vem de longa data, desde a organização, nos séculos XVII e XVIII, da produção capitalista industrial; período que 
Foucault ${ }^{5}$ denominou "grandes internações" (Barros, 1994). Desde então, um dos principais critérios para exclusão de parcelas da população era a sua capacidade ou aptidão para o trabalho na produção capitalista.

Até a ldade Média, os fenômenos da loucura e da doença mental não estavam vinculados à noção de periculosidade, ainda que associados à anormalidade e à animalidade, nem à segregação institucionalizada; sua exclusão estava relacionada à precariedade comum não apenas aos loucos, mas aos outros pobres e marginalizados. Até o século XVII, a loucura, antes considerada como algo sagrado ou exorcizado ${ }^{6}$, entendida como fenômeno abstrato localizado entre o natural e o sobrenatural, transformou-se em questão social, objeto de preocupação da nova ordem social.

Nas sociedades pré-capitalistas, a aptidão para o trabalho não era um critério importante na determinação do normal e do anormal ${ }^{7}$; isto decorria do fato de que as formas de organização do trabalho nessas sociedades eram pouco discriminativas para as diferenças individuais. Tanto o trabalho agrícola como o artesanato para o consumo imediato ou troca nos mercados da época permitiam as variações individuais, o respeito ao tempo e ritmo psíquico de cada trabalhador; características que ao invés de desqualificar o trabalho são incorporadas no produto mesmo do trabalho; tal qual o trabalho artístico, onde as diferenças individuais e os diversos estados anímicos são consideradas expressões do artista em sua obra. Nessa lógica, o autor considera que não seja uma simples coincidência que exatamente essas três atividades (trabalho agrícola, artesanal e artístico) sejam até hoje propostas como técnicas de tratamento e ressocialização dos doentes mentais (Rezende, 1987).

Foi justamente o princípio do fim do campesinato como classe e o declínio dos ofícios artesanais que selaram a sorte do louco e elevaram a loucura à categoria de problema social. As transformações no processo de trabalho modificaram radicalmente a noção de trabalho, antes relacionada à idéia em que se trabalha para viver, substituindo-a pelo espírito do cálculo e

\footnotetext{
${ }^{5}$ A esse respeito ver a obra clássica do autor publicada em 1978 sob o título História da Loucura na Idade Clássica.

${ }^{6}$ Para o estudo da história da loucura na antiguidade ver a primeira parte da trilogia de Pessoti (1994), publicada sob o título As loucuras e as épocas.

${ }^{7}$ A esse respeito, ver Canguilhem (1982).
} 
lucro, em que se deve viver para trabalhar. A rotina artesanal baseada na tradição passou a ser vista como carente de disciplina, irracional quanto ao conceito de tempo e vida. Entretanto para o homem da época, rural ou urbano, a idéia de liberdade era incompatível com a subordinação a um processo de trabalho vigiado e controlado, só conhecido nos presídios ou nas casas de correção. Durante esse período de transição as cidades estavam repletas de desocupados, mendigos de toda ordem enquanto havia escassez de mão de obra. No campo a situação não era diferente, homens desesperados sem-terra tornaram-se assaltantes de estradas, ladrões e vagabundos (Kofler apud Resende, 1987).

As medidas legislativas de repressão à mendicância e à ociosidade em toda a Europa, que incluíam o chicoteamento, a marcação do corpo com ferro em brasa, a pena de morte, pesadas multas e prisões aos pais que se recusavam a mandar seus filhos para o trabalho na indústria, culminaram na criação de instituições, como as casas de correção e de trabalho e os chamados hospitais gerais, que se destinavam a "limpar das cidades mendigos e anti-sociais em geral, e a prover trabalho aos desocupados, punir a ociosidade e reeducar para a moralidade mediante instrução religiosa e moral" (Resende, 1987, p. 24).

Este modelo acabou por fracassar, pois os hospitais gerais custeados pelo Estado, ao abrigar os desempregados nos ateliês obrigatórios, acabavam por comprometer a concorrência, diminuindo as vendas e aumentando o desemprego entre os produtores, além de apresentar um elevado custo de manutenção (Foucault, 1978).

\begin{abstract}
Este mecanismo, porém, teve um teve um papel fundamental para estabelecer uma determinada consciência ética: o valor do trabalho como eixo regulador da sociedade. Em tempos de transformação social e afirmação do poder burguês, a ociosidade passou a ser considerada uma afronta a Deus e o trabalho passou a ser uma exigência irrefutável (Souza, 2006, p. 2).
\end{abstract}

As transformações provenientes da urbanização e industrialização do nascimento do capitalismo determinaram um novo lugar social aos indivíduos, distinguindo a pobreza capacitada da pobreza enferma, sendo a primeira essencial à produção de riquezas enquanto a segunda, improdutiva, 
passou a carregar uma negatividade dada pela sua incapacidade às novas formas de produção e à nova organização social burguesa (Barros, 1994).

À loucura, devido à impossibilidade de sua inclusão nas categorias jurídicas da sociedade burguesa, tornou-se elemento contraditório que necessitava ser regulado e controlado, evitando assim problemas à nova ordem. Essa contradição foi equalizada, segundo Castel (1978), a partir da constituição de uma disciplina, a medicina mental, e de uma nova relação social: a relação de tutela; aos quais os loucos estariam submetidos.

Aos alienistas coube a ordenação do espaço hospitalar reunindo três dimensões: "classificação do espaço institucional, arranjo nosográfico das doenças mentais, imposição de uma relação específica entre médico e doente, o 'tratamento moral'” (Castel 1978, p. 81). A partir dessa ordenação, a loucura recebeu o estatuto de doença mental que associada à noção de periculosidade, tornou-se o objeto de uma nova disciplina, a psiquiatria, cuja assistência apresentava um duplo caráter sobreposto: punição e tratamento.

O nascimento da clínica parece indicar a coincidência entre improdutivo e doente, a integração entre mundo produtivo e medicina. A contradição reemerge quando o desvio psíquico entra na esfera de competência da medicina e a nova disciplina [...] não se revela imediatamente capaz de controlar a patologia relacional que seria seu corpo específico. A primeira grande operação para a qual a ciência psiquiátrica prepara-se é a transformação de uma multidão confusa, inútil ou perigosa em multiplicidade ordenada. Enfim seu complemento fundamental torna-se a sanção jurídica que não matiza a ambigüidade do seu objeto: nasce uma disciplina que encontra no controle social a sua especificidade e o seu fundamento" (Basaglia, 1978 apud Barros, 1994, p 35).

O fenômeno da urbanização, fato que ocorreu por vezes de forma violenta, denominado por Marx (1890) de processo de acumulação primitiva $^{8}$, ponto de partida do modo capitalista de produção, obrigou grandes massas humanas, que súbita e violentamente foram privadas dos seus meios de subsistência, a instalar-se nas cidades urbanas como levas de proletários, destituídos de direitos e desligados da organização coorporativa. Sem alternativa de subsistência, após serem despojados de suas terras, de seus meios de produção e de seus instrumentos de trabalho,

\footnotetext{
${ }^{8}$ Para Marx, esse período foi fundamental ao surgimento do capitalismo na história moderna, especialmente com relação à expropriação dos meios de produção coletiva, principalmente a terra, que passaram a ser controlados privadamente por uma classe emergente: a burguesia.
} 
que senão a "liberdade" de vender sua força de trabalho ao capitalista, os indivíduos foram obrigados a se adequar à nova sociedade burguesa e às suas relações de produção. Àqueles que não conseguiam ajustar-se à produção nem aos novos códigos sociais restou o controle social do Estado, para evitar desvios e perturbações à nova ordem social. Aos loucos, um conjunto de códigos teóricos, médicos e burocrático-administrativos passou a regulá-los e a normalizá-los.

\begin{abstract}
Insensato, ele não é sujeito de direito; irresponsável, não pode ser objeto de sanções; incapaz de trabalhar ou de "servir", não entra no circuito regulado pelas trocas, essa "livre" circulação de mercadorias e de homens à qual a nova legalidade burguesa serve de matriz. Núcleo de desordem, ele deve ser reprimido, porém, segundo um outro sistema de punições do que o ordenado pelos códigos para aqueles que voluntariamente transgrediam as leis (Castel, 1978, p. 19).
\end{abstract}

A legislação que acompanhou essa ordenação reforçou o aspecto da periculosidade e de ordem pública, que acompanharam a psiquiatria desde seu início, processo esse que é contíguo ao nascimento do capitalismo e do Estado burguês. Sendo assim, "as novas significações atribuídas à pobreza, a importância dada à obrigação do trabalho e de todos os valores éticos a ele ligados, determinam a experiência que se faz da loucura e modificam-lhe o sentido" (Foucault,1978, p.78). Nesse período, tornou-se ainda mais visível a justificativa da exclusão da loucura pela incapacidade de inserção no mercado de trabalho.

\title{
2. A centralidade do trabalho na instituição psiquiátrica: o tratamento moral
}

Ao final do século XVIII, as idéias do lluminismo, os princípios da Revolução Francesa e a declaração dos direitos do homem nos EUA, influenciaram as crescentes denúncias das internações (seqüestro) arbitrárias dos doentes mentais somadas às precárias condições de confinamento junto a toda espécie de marginalizados, além das torturas e violências aplicadas com ou sem justificativa terapêutica (Rezende, 1984). Entretanto as reformas políticas e sociais que se seguiram determinaram novos mecanismos de exclusão/inclusão, especialmente para os loucos, que permaneceram nas instituições enquanto aqueles considerados capazes de 
produzirem, livres dos grilhões, foram compor a massa de operários necessária à produção industrial da época (Barros, Egry, 2001).

Pinel na França, Tuke na Inglaterra, Chiarugi, na Itália, Haslan e Daquin, os principais expoentes do alienismo, pela primeira vez na história ocidental, passaram a qualificar os loucos como doentes e estabelecer todo um sistema de normatização da loucura (Amarante, 1996). A partir desse momento:

...um estabelecimento de internação tornou-se um hospital
psiquiátrico, um organismo de tratamento. Desde então, os
distúrbios mentais tornaram-se o objeto da medicina e uma
categoria social chamada de psiquiatria nascera (Foucault, 1999).

Philippe Pinel, um dos fundadores da clínica médica, assumiu em 1793 a direção do Bicêtre, onde operou importantes modificações baseadas em sua nosografia, desenvolvidas no Traité Medical-Philosophique sur L'aliénation Mentale, que buscava compreender o fenômeno da loucura dirigindo sua "atenção para os sinais e sintomas da loucura em detrimento da procura de sua sede no organismo" (Castel, 1978 apud Amarante, 1996).

$\mathrm{Na}$ concepção pineliana, o regime de completo isolamento, onde se poderiam submeter os loucos a um tratamento asilar, não representava a privação da liberdade; ao contrário, para Pinel, era justamente o isolamento que poderia restituir-Ihes a liberdade subtraída pela alienação (Amarante, 1996).

A teoria pineliana influenciou a partir daí o modo como a sociedade passou a se relacionar com a loucura. Reunindo e dando corpo aos saberes médicos e filosóficos que estavam sendo produzidos sobre a loucura, Pinel definiu um estatuto teórico da alienação mental que fora apropriado pelo discurso e pelas instituições médicas, ao passo que abriu espaço para possibilidades terapêuticas e de cura por meio do tratamento moral.

O tratamento moral buscava restabelecer a ordem no exercício das funções e faculdades, uma vez que a desordem física e moral constituía para os alienistas o traço mais evidente da loucura. Essa modalidade terapêutica, embora devesse a princípio ser ajustada a cada caso particular, foi administrada de forma coletiva e impessoal a partir de um conjunto de 
"disciplinas gerais, horários fixos, trabalhos rotinizados e divertimentos regulados" (Castel, 1978).

O primeiro e mais fundamental princípio terapêutico do tratamento moral era o isolamento do mundo exterior, justificado pelo isolamento das causas da alienação mental que estariam presentes no meio social. Cientificamente fundamentado, o isolamento afastava (seqüestro) o louco da família e da sociedade, estabelecendo assim o paradigma da internação que até os dias atuais não foi totalmente superado (Amarante, 1996). Conforme Esquirol, que desenvolveu a teoria pineliana:

$O$ isolamento é frequentemente uma necessidade urgente e absoluta, tanto para a segurança do próprio enfermo como da família, assim como para a tranquilidade pública e esta necessidade é mais urgente para os indivíduos que pertençam às classes sociais menos afortunadas ou pobres (Espinosa, 1975 apud Silva Filho, 1987, p.89).

$\mathrm{Na}$ concepção pineliana, o tratamento moral inicia-se no próprio regime disciplinar da instituição, e em seguida na utilização do trabalho, considerado uma forte terapêutica contra o delírio, contra o pensamento desorganizado, capaz de trazer a consciência para a realidade, organizando o louco a partir de uma rotina de horários e atividades.

O trabalho no tratamento moral não possuía nenhum valor de produção. Apresentava-se com um caráter ético e moral; ético, pois se dirigia ao valor que a ordem burguesa atribuía ao trabalho como uma obrigação contra a preguiça, como uma condenação contra a ociosidade; e moral, pois se constituía numa punição, numa submissão à ordem, numa limitação da liberdade, para banir a ociosidade e desalienar o espírito, castigando e corrigindo certas falhas morais. $O$ uso do trabalho no tratamento moral tem, portanto, uma intenção terapêutica, uma finalidade de cura, bem como um objetivo de controle social, de manutenção da ordem pública, como inicialmente nos hospitais gerais. (Guerra, 2000).

O trabalho, no tratamento moral, é reconhecido como principal meio de cura, pois significava coordenação dos atos, atenção, obediência às regras e às fases da produção, permitindo também o controle de cada ato e de cada gesto e a coordenação e ordenamento do corpo e da mente. Evidentemente, o trabalho das oficinas, dos jardins ou nos serviços das 
instituições psiquiátrica era prescrito apenas para os pobres; aos ricos era necessário criar jogos e bibliotecas (Machado, 1978).

A utilização do trabalho no tratamento moral, portanto, respondeu à necessidade de reintroduzir os improdutivos no circuito da produção explorando sua força de trabalho ao passo que neutralizava o risco da desordem social. Com o uso de técnicas disciplinares, o tratamento moral buscava impor a recuperação da razão e a domesticação do povo, a partir da interiorização das regras e valores que garantissem a reprodução da ordem burguesa, como se pode constatar no texto de barão De Gerando (apud Castel, 1978, p. 140):

\begin{abstract}
Não se trata somente, como se supõe, de proporcionar trabalho ao indigente; trata-se, frequentemente, de lhe dar educação para o trabalho em qualquer idade; isto é, de lhe inspirar o gosto, de lhe fazer adquirir a capacidade e contrair o hábito do trabalho. Não se trata, como se supõe, de atingir apenas um objetivo econômico, (...) trata-se, antes de mais nada, de atingir um objetivo moral.
\end{abstract}

Esquirol desenvolveu as mesmas linhas de tratamento iniciadas por Pinel, mantendo, apesar das críticas, o princípio pineliano de que a alienação teria uma causa exclusivamente moral, cuja terapêutica implicaria na imposição do asilamento e do tratamento moral (Amarante, 1996). Esquirol dá um passo importante na história da psiquiatria em direção ao conceito médico da loucura, ao conceito de doença mental.

O conceito de monomania elaborado por Esquirol, passo decisivo
na definição psiquiátrica da loucura, deixa claro que o nível das
paixões é muito mais fundamental enquanto característica da
alienação mental, do que o da inteligência, portanto sua
característica essencial é a perversão da vontade que é um
fenômeno moral e não, intelectual (Barros, Egry, 2001, p. 28).

O tratamento moral apresentava resultados práticos e sua aplicação dependia da correta administração do asilo, instituição considerada pelos alienistas por si só terapêutica. Embora enfraquecido pelo crescente debate entre o físico e moral e seu insucesso na cura dos alienados, o tratamento moral ainda era visto como o meio terapêutico que apresentava melhores resultados, passando a assumir um caráter mais amplo com a teoria da degenerescência de Morel (Amarante, 1996).

Mesmo após a decadência do alienismo e a crítica da prática asilar, alvos do questionamento organicista, o tratamento moral e a utilização do 
trabalho se justificavam pela necessidade de restauração de uma ordem social cuja regra econômica pode ser a produtividade, mas não sempre, e a consequente extração de mais-valia, funcionando na prática como um depósito de força de trabalho excedente (Silva Filho, 1987).

O julgamento de incapacidade para o trabalho dos loucos, circunscrito a determinados padrões de modos de produção, coincide com o julgamento de que as classes trabalhadoras também eram incapazes de conduzir suas vidas e de pensar por si mesmos, preconceito que ainda não foi superado, mesmo após as lutas do movimento dos trabalhadores ao longo dos anos (Souza, 2006). Entretanto, como havia a necessidade de acumulação e reprodução ampliada de capital através da exploração do trabalho na produção capitalista, aos operários foi possível viver e com freqüência morrer nessa liberdade de vender sua força de trabalho na produção, enquanto o louco permaneceu trancado no hospício sem sequer poder reivindicar sua entrada no circuito da produção (Castel, 2001). Ao louco coube, entretanto, submeter-se a um sistema disciplinar regido pela mesma lógica do mundo exterior, que a partir da obrigatoriedade do trabalho, teria o poder de educá-lo, corrigi-lo e curá-lo para reintroduzi-lo no mundo produtivo dos normais.

A partir do século XIX, com o desenvolvimento do capitalismo industrial e a necessidade de um exército de reserva de força de trabalho, abriram-se os portões das instituições de internação, no entanto, somente àqueles que tinham capacidade de trabalhar. Os que eram considerados incapazes de ingressar ao modo de produção e à sociedade, permaneceram no interior das instituições, considerados como pacientes com distúrbios de caráter psicológico (Foucault, 1999).

$\mathrm{Na}$ teoria das degenerações de Morel, o embate entre o somatismo e o psicologismo ficou aparentemente resolvido já que as instâncias física e moral eram tidas como interdependentes e ambas expressavam a presença da loucura. Com Morel o tratamento moral ultrapassou sua aplicação individualizada, deslocando-se do interior do asilo para o meio social e político, "moralização das massas" (Castel, 1978), com a intenção de corrigir os desvios da degeneração e evitar o aparecimento de novas ordens de 
degenerações, em outras palavras, para interromper as linhagens degeneradas, evitando assim a contaminação da sociedade pelos degenerados. O conceito de predisposição de Magnan foi desenvolvido com base na teoria de Morel, e influenciou a psiquiatria moderna de Kraepelin (Amarante, 1996).

A teoria kraepeliana, segundo os estudos de Sousa (2006), portanto, encontra-se no bojo de um processo do Alienismo, na busca das causas para a loucura, onde a noção de degenerescência está associada à pobreza:

O pauperismo representa, assim, uma espécie de imoralidade que se faz natureza a partir da degradação completa dos modos de vida dos operários e de suas famílias. O alienista Morel vai, aliás, construir seu conceito de degenerescência, que tem um belo futuro pela frente, a partir da observação dos operários da indústria têxtil e dos membros de suas famílias albergados no asilo de Saint-Yon, perto de Rouen. A degenerescência exprime uma degradação da espécie humana, hereditária, mas não originária (Castel, 1998, p. 287).

O pauperismo, classificado por Castel (1998, p.287) como um "racismo antioperário amplamente difundido entre a burguesia do século XIX", se refere às condições de vida da classe operária nascente, cuja instabilidade do trabalho e a alternância entre emprego e desemprego, geram seu amontoamento nos subúrbios das cidades industriais, onde a promiscuidade, a violência, o alcoolismo, a prostituição, a falta de higiene, representam uma espécie de imoralidade a partir da degradação completa dos seus modos de vida. No artigo "Pauperismo" de Émile Chevalier, esta condição está associada também às faculdades mentais:

O pauperismo é uma condição nova, tanto por suas causas quanto por seu caráter. Sua origem é devida à organização industrial de nossa época contemporânea; reside na maneira de ser e de viver dos operários de manufaturas [...]. Supõe um aniquilamento do ânimo, um rebaixamento e uma corrupção das faculdades mentais (apud Castel, 1998, p. 288).

Além da afirmação da concepção organicista/biológica da loucura, tendo o psiquiatra alemão Kraepelin como uma das maiores referências, a psiquiatria do século XIX também assistiu a uma nova revolução com as descobertas de Freud, cujas teorias sobre o inconsciente abriram espaço para uma concepção psicodinâmica da loucura e para as teorias psicoterápicas que dela derivaram (Barros, Egry, 2001). 
O século XX marca uma nova fase da clínica psiquiátrica em termos de reformulações e experiências inovadoras. Principalmente no período pósguerra, assistiu-se às experiências da "psiquiatria reformada" e à consolidação de uma nova profissão, a terapia ocupacional, que buscava um novo enfoque para o uso da atividade e do trabalho no campo psiquiátrico. A psiquiatria tradicional sofria inúmeras críticas e questionamentos, considerada excludente e marginalizadora. A assistência passou a se organizar a partir de novos modelos com dispositivos abertos e comunitários, buscando o resgate da cidadania, da singularidade e da inclusão social. As chamadas oficinas retomam o uso atividade e do trabalho sob novas bases, especialmente sob a perspectiva da reabilitação (Guerra, 2000).

No início do século XX, Hermann Simon, criador da ergoterapia, se espantou com a grande melhora dos pacientes que trabalharam na construção do hospital psiquiátrico. Sua teoria foi utilizada pelas práticas e saberes da terapia ocupacional nesse novo movimento. Bion e Menninger, teóricos de grupo, também fizeram algumas experiências em hospitais psiquiátricos, que influenciaram as comunidades terapêuticas da Inglaterra, a Psicoterapia Institucional na França e a Psiquiatria Comunitária dos EUA (Souza, 2006).

Entretanto a Psiquiatria Democrática Italiana ${ }^{9}$, movimento antimanicomial tardio em relação às outras experiências, transformou radicalmente a assistência à saúde mental a partir da ruptura e superação do paradigma psiquiátrico e da desmontagem da instituição hospitalar. Com o lema "a liberdade é terapêutica", desconstruiu e inventou novos serviços, dentre eles os laboratórios e as cooperativas sociais, onde o trabalho era

9 Expressão designada ao processo de reformulação da assistência à saúde mental ocorrido na Itália, baseado na profunda crítica do paradigma psiquiátrico tradicional e na implantação de uma rede de serviços territoriais propondo a desconstrução da lógica manicomial em direção à desinstitucionalização como emancipação. Esta experiência desenvolveu-se primeiramente na cidade de Gorizia em 1961 e depois em Trieste, a partir de 1971, quando Franco Basaglia, principal expoente desse movimento, assumiu o cargo de diretor do hospital psiquiátrico de San Giovanni. A esse respeito, ver a obra coordenada por Basaglia, publicada em português no ano de 1985, sob o título A instituição negada: relato de um hospital psiquiátrico e também os estudos de Denise Dias Barros (1994) sobre a experiência italiana publicada com o título Jardins de Abel: desconstrução do manicômio de Trieste. Sobre esse tema, ver também Nicácio (1990) e Rotelli (1994). 
considerado como uma real possibilidade de inserção e circulação social, de ampliação da contratualidade que elevava o sujeito à condição de cidadão.

Contudo, a utilização do trabalho é tão antiga quanto o manicômio (Saraceno, 2001). O trabalho na psiquiatria foi considerado como critério de diagnóstico, estratégia de tratamento e indicador de cura (Birman apud Mângia, 1997).

Como vimos, a utilização do trabalho na história da saúde mental foi se modificando ao longo da história das instituições, apresentando-se com variadas formas e sentidos: controle social, tratamento moral, ergoterapia, laborterapia, praxiterapia, terapia ocupacional, até configurar-se como um recurso de reabilitação psicossocial. Tal evolução não se deu de forma linear: essas lógicas muitas vezes co-habitavam num mesmo espaço e tempo.

$\mathrm{Na}$ experiência brasileira ${ }^{10}$, a trajetória do doente mental pela história do Brasil colônia pouco difere da tendência histórica universal; aos loucos pobres era permitido vagar pelas cidades e campos e nos casos de comportamento violento ou indecoroso eram recolhidos às cadeias, podendo ou não ser vítimas de maus-tratos. Com a inauguração do hospício $D$. Pedro II, em 1852, na cidade do Rio de Janeiro, iniciou-se a história da assistência psiquiátrica no Brasil. A tendência central da assistência psiquiátrica brasileira, desde seus primórdios, é a exclusão dos loucos nas diversas instituições inauguradas em todo o território, como as Santas Casas de Misericórdia, onde o controle administrativo estava a cargo das religiosas. Sua intenção era a simples segregação dos desviantes e carecia de base científica sólida (Rezende, 1987).

$\mathrm{Na}$ psiquiatria científica, inaugurada com a Proclamação da República, houve uma entusiástica adesão à lógica de construção de colônias agrícolas, não por uma motivação terapêutica, mas pela necessidade ditada pelo nascente capitalismo em reverter a considerada moleza do brasileiro com relação ao trabalho (Rezende, 1987). A vadiagem era considerada delito e punida com a prisão. Desde então, a noção de

\footnotetext{
${ }^{10}$ Para um estudo sobre a história da psiquiatria brasileira, ver Amarante (1982, 1998), Barros (2001), Costa (1989), Machado (1978), Mângia (2002) e Rezende (1987).
} 
cidadania no país estivera associada à inserção do indivíduo numa categoria profissional reconhecida e definida por lei.

Nas colônias agrícolas desenvolvidas por Franco da Rocha, herdeiro das concepções do tratamento moral europeu, a utilização do trabalho constituía-se tanto como recurso terapêutico como exploração de mão de obra não remunerada para manutenção da própria instituição (Mângia, 2002). A organização do trabalho nas colônias também seguia uma divisão social de classe e de gênero, como podemos ver na citação a seguir:

A cozinha e a lavanderia são lugares de trabalho para doentes de classe inferior, ao passo que as ocupações de caráter mais elevado são próprias principalmente para os que estão habituados com elas (Rocha apud Mângia, 2002, p. 93).

Além da condenação moral da ociosidade, o trabalho teria a função terapêutica de afastamento das manifestações da loucura como as fantasias e energias nervosas destrutivas, garantido também melhoras nas funções fisiológicas como sono e nutrição, permitindo a instauração de novos hábitos (função pedagógica) e contribuindo para a ordem e economia institucional (Mângia, 2002).

A maioria dos Estados Brasileiros inaugurou colônias agrícolas em sua rede de serviços como um complemento aos hospitais gerais ou como opção predominante. A utilização do trabalho a partir da praxiterapia pretendia reproduzir a vida de uma comunidade rural, ao mesmo tempo em que excluía os doentes do convívio social. As atividades rurais como o plantio de frutas e hortaliças e a criação de animais, associadas às oficinas de ferraria, mecânica, elétrica, entre outras, eram consideradas alternativas terapêuticas que buscavam não apenas recuperar a produtividade dos loucos e sua relação com a comunidade num ambiente favorável e tranqüilo, mas também a exploração de sua mão-de-obra para a manutenção da instituição. A noção de reabilitação, que estava associada ao tratamento moral, considerava o trabalho como elemento central no tratamento.

Entretanto a incapacidade de devolver os loucos reabilitados à sociedade acabou por determinar o fracasso desse modelo que se tornou obsoleto, uma vez que sua vocação agrária se antagonizava com a realidade de urbanização e industrialização nas cidades. Esse período se 
caracteriza por utilizar o trabalho com o propósito de ocupar o tempo ocioso, gerar renda para a manutenção das colônias e asilos e garantir a ordem social no contexto da consolidação da República e do surgimento dos centros urbanos e industriais (Guerra, 2000).

A utilização da atividade e do trabalho na assistência psiquiátrica brasileira ganhou novo fôlego a partir da década de $1940 \mathrm{com}$ a terapêutica ocupacional desenvolvida por Nise da Silveira. $O$ uso de atividades na reabilitação dos doentes passou a ganhar o valor terapêutico similar às demais terapêuticas de cunho organicista, graças também ao reconhecimento mundial da necessidade de reabilitação psicossocial em termos de recuperação de força de trabalho. Denunciando os desvios da utilização do trabalho como exploração de mão-de-obra gratuita, Nise da Silveira destacava o respeito à produção subjetiva do louco, e o benefício que uma ocupação livremente escolhida e metodicamente dirigida poderia oferecer aos doentes, crônicos e agudos. Desenvolveram-se, então, uma variedade de atividades agrupadas em oficinas que envolviam atividades produtivas, expressivas e culturais, visando também à expressão dos conflitos intrapsíquicos (Guerra, 2000).

A contribuição de Nise da Silveira, entretanto, só foi reconhecida décadas depois, já que a introdução dos medicamentos (década de 1950) predominou na assistência da época e a seguir a política de saúde privatizante desenvolvida pela ditadura militar ampliou a lógica de institucionalização e mercantilização da loucura.

O período que se seguiu ao regime militar de 1964 marca uma linha divisória entre uma assistência destinada ao doente mental indigente e uma assistência destinada à massa de trabalhadores e seus dependentes, onde a opção, dada as condições de superlotação e de precariedade dos hospitais públicos, foi a contratação de leitos privados que cresceram extraordinariamente nesse período. A assistência psiquiátrica se caracterizava por uma combinação entre uma finalidade terapêutica e certas funções político-administrativas, que se resumiam, em: curar, recuperar a força de trabalho a partir da produção, auto-reproduzir o sistema de assistência e setores da economia ligados a ele (indústrias de 
medicamentos), ideologizar as relações sociais, dando um lugar de exclusão aos desviantes e normatizar os comportamentos visando homogeneizar as diferenças individuais (Rezende, 1987).

O período posterior à chamada indústria da loucura foi marcado com denúncias por parte dos representantes da saúde mental no país, cobrando maior eficiência e menos gastos. A criação de novos serviços como ambulatórios, a regionalização, a condenação do macro-hospital, as campanhas pela reabilitação dos doentes visando sua reintegração social, são as principais ações do documento assinado pelo Ministério da Saúde em 1972 conjuntamente com outros países latino-americanos. Apesar desse discurso, a década de 1970 marca uma forte tendência de redução de gastos com saúde mental, em favor de outros setores da assistência médica (Rezende, 1987).

A centralidade do trabalho não ocorria apenas dentro das instituições psiquiátricas; mas fora delas, a sociedade se organizava a partir do trabalho. Com a descoberta da relação entre riqueza e trabalho, o trabalho como produtor de riqueza determinou o lugar dos produtivos e dos improdutivos. $\mathrm{Na}$ concepção marxista, a riqueza das sociedades onde rege a produção capitalista configura-se na acumulação de mercadoria, cujo valor é determinado pelo trabalho. Portanto, a importância do trabalho determina não apenas o lugar dos indivíduos na sociedade, mas também toda a estrutura social. No caso da assistência psiquiátrica, a relação com o mundo do trabalho determinou sua função social: a de controle dos improdutivos e desviantes (Castel,1978).

Nesse sentido, a história da loucura na sociedade ocidental e o grau de tolerância com a anormalidade estão diretamente ligados ao nascimento da era industrial e à necessidade ditada nas suas diversas fases de expansão; as quais corresponderiam às progressivas transformações técnico-administrativas no campo psiquiátrico, cuja função primordial relaciona-se ao controle social explícito dos elementos não controláveis para a manutenção da ordem pública (Basaglia, 1971). 


\section{Reformas Psiquiátricas e Reabilitação Psicossocial no eixo trabalho}

O movimento que se convencionou chamar de Reforma Psiquiátrica ${ }^{11}$, surgido no período do pós-guerras, se caracterizou por uma reformulação da assistência em saúde mental. Em alguns países como os EUA, Inglaterra, França, mas principalmente na Itália, vários autores $\mathrm{e}$ atores se empenharam na tarefa de desconstrução/invenção, desenvolvendo saberes e práticas desinstitucionalizantes e antimanicomiais, ao mesmo tempo, travando uma luta teórica, técnica, política, jurídica, cultural e assistencial contra aqueles que transformaram a loucura e suas expressões em mercadoria para benefício de alguns poucos. Nesse sentido, essa luta específica se inscreve na luta mais geral da sociedade pela transformação nas relações de poder e na produção e reprodução da vida, que tem como categoria principal as relações sociais de produção e que objetiva a mudança nas condições de vida dos trabalhadores e mais recentemente dos "excluídos" do ciclo produtivo, no sentido de sua emancipação.

O Movimento da Reforma Psiquiátrica e da Luta Antimanicomial no Brasil $^{12}$ configurou-se como um dos movimentos sociais de luta pela redemocratização do país, englobando diversos atores como trabalhadores, usuários, familiares, intelectuais, artistas, sindicalistas e comunidade, que se dispôs a articular esses saberes e práticas na elaboração de práticas transformadoras no campo da saúde pública como também nas suas interfaces: promoção social, assistência jurídica, cultura, esportes, lazer, moradia, trabalho, educação, entre outros.

No Brasil, o processo de Reforma Psiquiátrica, sob inspiração de outras experiências mundiais e no bojo da Reforma Sanitária, desde seu início, final da década de 70 , passou por inúmeras e ricas reflexões e debates, desconstruções e invenções, e elevou seu grau de importância e

\footnotetext{
${ }^{11}$ A expressão reforma psiquiátrica aqui utilizada refere-se ao debate dos últimos anos no campo da saúde mental, sobretudo após a Segunda Grande Guerra, quando as iniciativas de reforma da psiquiatria, que anteriormente apresentavam variados títulos, se intensificaram, originando projetos mais delimitados de natureza técnica e administrativa sobre o campo disciplinar e de intervenção psiquiátrica, e passando a serem explicitamente chamadas de reformas psiquiátricas. A esse respeito, ver Amarante (1996).

${ }_{12}$ Para um estudo sobre a história do movimento brasileiro de luta antimanicomial, ver Amarante $(1990,1998)$.
} 
efetividade quando passou a ser considerado como política oficial do Ministério da Saúde para a saúde mental.

Foram implantados desde então inúmeros dispositivos, programas e estratégias extra-hospitalares, como CECCOs, CAPS, RTs, Programa de Volta para Casa, Redução de Danos, Associações de Usuários e Familiares, entre outros, compondo um sistema de saúde mental, organizado numa rede de serviços implantados no território, que se orientam pela desinstitucionalização, pela participação social e pela reabilitação psicossocial dos usuários. Essa rede deve abranger a complexidade das necessidades das pessoas com sofrimento mental ${ }^{13}$.

Seguindo a mesma lógica, mais recentemente, acompanhamos a discussão coletiva sobre os projetos de inclusão social a partir do trabalho e o estabelecimento da parceria entre a Reforma Psiquiátrica e a Economia Solidária.

O desenvolvimento de projetos de inserção laborativa não é recente. Sabemos que na experiência italiana da reforma psiquiátrica a criação de laboratórios e cooperativas foi o fator impulsionador na discussão do trabalho emancipado versus trabalho institucional, este último quer seja dentro dos muros reais ou nos muros simbólicos da lógica manicomial. Por ser uma estratégia já muito difundida nesse país desde o contexto pósguerras, a cooperativa é considerada como um recurso reabilitador no sentido da desinstitucionalização como emancipação.

A noção de Reabilitação foi formulada e desenvolvida a partir da mudança assistencial do pós-guerra, no contexto do Welfare State e da implantação do Estado de Direito, vinculando a idéia de cidadania para todos (Barros, 1991).

No campo da saúde mental, é também nesse contexto que se iniciaram as Reformas Psiquiátricas nos EUA e na Europa, redirecionando a assistência para dispositivos comunitários. Entretanto, essas novas técnicas de reabilitação do tipo comunitário estavam designadas a reabilitar pessoas para suprir a necessidade econômica de incremento de mão de obra.

\footnotetext{
${ }^{13}$ Acerca das políticas atuais de assistência à saúde mental, consultar as publicações do Ministério da Saúde (Brasil, 2004, 2005 e 2007).
} 
Também objetivavam a redução de gastos com os hospitais psiquiátricos (Basaglia,1971).

A redução da população de internados na Inglaterra e nos EUA teve uma forte motivação econômica associada à confirmação do baixo potencial terapêutico dos hospitais. Nesses modelos, à exceção da reforma italiana, o processo de desinstitucionalização se caracterizou simplesmente pela desospitalização, transferindo multidões de pacientes "do abandono manicomial ao abandono extra-manicomial" (Saraceno, 2001).

Tal fenômeno de desospitalização, acompanhado pelo crescimento da afirmação de direitos dos pacientes, fez surgir uma necessidade de responder as demandas dos ex-internados e consequentemente criou a necessidade de sua reabilitação no sentido da reinserção social.

Destacamos a importância da psiquiatria democrática italiana que, criticamente às demais experiências européias e norte-americana, objetivava a transformação da vida concreta e cotidiana dos sujeitos a partir de uma rede composta por serviços territoriais: "os plantões psiquiátricos noturnos no hospital geral, as cooperativas, as casas para os pacientes, os bares e os refeitórios de bairro, os jogos, os laboratórios de teatro etc..." (Rotelli, 1990).

Em sua postulação, Saraceno considera a reabilitação psicossocial como um processo que implica na abertura de espaços de negociação para os pacientes, sua família e a comunidade circundante. Nesse sentido, introduz o conceito de contratualidade, ou seja, a capacidade de engendrar contatos sociais, o que permitiria ao usuário subverter o processo de reclusão que é resultado dos efeitos da doença mental e da "exclusão social" (ou melhor, inclusão marginal), condição esta caracterizada pela precariedade de existência material e subjetiva.

A noção de reabilitação psicossocial e da utilização do trabalho na proposta italiana sofreu profundas reformulações em relação às demais experiências reformadoras. Ao contrário das experiências desenvolvidas na Europa e nos EUA, onde a utilização do trabalho mantinha uma intenção terapêutica, adaptativa, cuja finalidade era a recuperação da mão-de-obra, na experiência italiana o trabalho era considerado uma possibilidade real de participação e melhoria da qualidade de vida, questionando a utilização do 
trabalho alienado, fonte de adoecimento e submissão ao modelo capitalista hegemônico, que foi responsável pela exclusão dos loucos e pela determinação de sua incapacidade produtiva.

A ruptura com esse paradigma excludente, se traduz numa mudança paradigmática, na qual: "o problema se tornará não a cura, mas a emancipação; não se trata de reparação, mas de reprodução social das pessoas; outros diriam, o processo de singularização e ressingularização" (Rotelli,1990, p. 91).

Nesse sentido, a proposta de reabilitação psicossocial italiana fundamenta-se na noção de desinstitucionalização basagliana, que em síntese, afirma como finalidade a emancipação do sujeito em sofrimento mental, concebendo a loucura como uma condição humana e não como ruptura da normalidade (Leão, 2006).

A noção de reabilitação na experiência italiana está, portanto, identificada com a reconstrução das histórias de vida, buscando recuperar condições materiais, sociais e emocionais para romper com a lógica da reprodução das relações de dependência. Nesse sentido, a questão do trabalho se tornou fundamental na busca de soluções alternativas para romper com os valores educativos, morais e sociais da ergoterapia, da ludoterapia e da exploração dos pacientes que representavam uma anulação total da existência humana (Barros, 1994).

Na Psiquiatria Democrática Italiana, o debate sobre o trabalho na assistência apresenta-se com uma natureza política associada à clinica, que busca a inclusão social a partir da ampliação das possibilidades de trocas na vida pública. Dessa maneira, observa-se uma ruptura com a ergoterapia e a utilização moral e pedagógica do trabalho no interior das instituições psiquiátricas buscando as reais possibilidades de inserção no território, onde se dão as relações sociais, onde se efetiva a cidadania. A utilização do trabalho, nessa lógica, foi um dos instrumentos de desconstrução e transformação dos mecanismos institucionais:

O trabalho entendido não apenas como prática de "normatização" e, portanto, expressão necessária da produtividade, mas como resposta a uma necessidade de reprodução subjetiva, enquanto produtividade social, enquanto meio para a reconstrução de uma identidade em relação a uma capacidade de troca. Então trabalho 
significa possibilidade de valorização e expressão da subjetividade de cada um e da troca entre diversas experiências que se arriscam (Del Guidice e Cogliati apud Barros, 1994, p. 96).

Nesse sentido a questão do trabalho articula-se com a possibilidade de reprodução social, garantindo o exercício da cidadania das pessoas com transtornos mentais, que sofreram um duplo processo de exclusão, tanto pela sua fragilidade social como pela exclusão do mercado de trabalho. Trata-se de pensar a inclusão social do doente mental pelo mundo do trabalho, com um ideal maior que é a sua emancipação, como apontado na afirmação abaixo:

O horizonte estratégico será dado fundamentalmente pela cidadania, na possibilidade do exercício de seus direitos e pela produção de uma cultura de inclusão que dê oportunidade a essa população tornaram-se sujeitos de história própria (Barros, Aranha e Silva, Oliveira, 1995, p.177).

É nessa perspectiva que se insere a importância do protagonismo e do empoderamento ${ }^{14}$ dos sujeitos com sofrimento mental a partir de sua organização em movimentos sociais orientados à luta pelos direitos fundamentais. Entretanto, a luta pela garantia desses direitos, que nunca foram conquistados pela maioria da população, constituiu-se num desafio de todos os setores mais empobrecidos da população, cada vez mais crescentes em tempos de crise do capital, de reestruturação produtiva, de flexibilização de direitos trabalhistas e de desemprego que atinge vastas massas populacionais, não apenas no Brasil como no mundo.

A questão do trabalho é uma discussão central na organização da sociedade e na sua forma de produção e reprodução da vida. No campo da saúde mental, sua importância está relacionada ao processo de "exclusão" do ciclo produtivo desse segmento da população cujas barreiras foram amplificadas pela própria condição de saúde e pela reclusão histórica ao qual foram submetidos os indivíduos com sofrimento mental a partir de sua internação em instituições totais ${ }^{15}$ de caráter excludente e segregador.

Como categoria fundante do mundo dos homens, o trabalho numa visão dialética desenvolvida por Marx e Engels, deve ser compreendido enquanto um complexo fenômeno histórico que apresenta como função

\footnotetext{
${ }^{14} \mathrm{~A}$ esse respeito ver Vasconcelos (2003).

${ }^{15}$ Termo introduzido por Goffman (1974), utilizado pela experiência italiana.
} 
social a transformação da natureza nos bens materiais indispensáveis à reprodução de cada sociedade. $O$ trabalho também determina a consciência social dos seres humanos que interpreta, compreende e representa a si mesma e o que ocorre nas condições materiais de produção e reprodução da existência (Chauí, 1995). Portanto, considerando que é o trabalho um componente privilegiado da identidade dos indivíduos, o seu afastamento prolongado produz uma sensação de ser um excluído, caracterizado por sentimentos de improdutividade, de inutilidade, de marginalidade em relação ao mundo do trabalho.

Em resposta aos processos excludentes do sistema produtivo capitalista, surgem nos países centrais, desde o século XIX, experiências alternativas objetivando a criação de novas formas de organização da produção e de consumo. Entretanto, essas experiências ora desafiavam os princípios da economia burguesa ora buscavam minimizar os custos humanos da Revolução Industrial de modo compensatório. Surgiu, portanto, a idéia de autonomia associativa que re-apresentou princípios como a ajuda mútua, a cooperação, a solidariedade, a confiança, a educação para formas alternativas de produção, de consumo e de vida, desenvolvendo um conjunto de organizações sociais como cooperativas, associações mutualistas, organizações não governamentais, que configuraram a chamada "economia social" (Santos, s/d). No Brasil, esse movimento e princípios vêm sendo apresentados pela Economia Solidária, desenvolvida por autores como Paul Singer.

No campo da Reforma Psiquiátrica Brasileira, a problemática da inclusão social e promoção da cidadania, vêm sendo debatidas em conjunto com diversos setores, entre eles a Economia Solidária, o que resultou no Programa de Inclusão Social pelo Trabalho ${ }^{16}$, cuja proposta está vinculada à potencialização do trabalho como estratégia de inclusão social.

Ao longo da Reforma Psiquiátrica Brasileira, processo permanente de transformações nos campos assistencial, cultural e conceitual (Amarante, 1997), foram desenvolvidas inúmeras experiências e projetos de geração de renda e trabalho destinados aos usuários de saúde mental.

${ }^{16}$ A esse respeito, ver publicação do Ministério da Saúde (Brasil, 2006). 
As primeiras experiências brasileiras surgiram no início dos anos 1990, com destaque para três grandes experiências (Leal, 2004):

1) A Unidade de Reabilitação Psicossocial desenvolvida pelo Programa de Saúde Mental de Santos.

2) A Associação Franco Basaglia, associação de pacientes, familiares e amigos do CAPS Luiz Cerqueira, em São Paulo.

3) O Núcleo de Oficinas e Trabalho desenvolvido pelo Serviço de Saúde Dr. Cândido Ferreira, em Campinas.

Outras experiências brasileiras são merecedoras de destaque como o projeto Loucomotiva de Natal, o Núcleo de Saúde Mental e Trabalho (NUSAMT), a Cooperativa da Praia Vermelha no Rio de Janeiro, o Projeto POA de Porto Alegre, o projeto Suricato em Belo Horizonte, entre outras, refletindo um crescente interesse no tema da inclusão social pelo trabalho no campo da saúde mental (Leal, 2004).

O tema das oficinas geradoras de renda não é uma questão incipiente e sem qualquer tradição no contexto internacional da atenção psicossocial; a experiência americana, anglo-saxônica, francesa e italiana, "tomaram o desafio de fazer do trabalho um instrumento de reabilitação psiquiátrica fora do contexto hospitalar" (Leal, 2004, p. 13).

Destacamos o modelo italiano da "empresa social ${ }^{17 "}$ que defende a inserção no trabalho como um dos principais aspectos das intervenções reabilitadoras e desinstitucionalizantes, sem desconsiderar outros aspectos centrais da vida das pessoas com sofrimento mental. O conceito de empresa social é heterogêneo, com significados diferentes e por vezes antagônicos sobre a relação entre assistência e mercado. A concepção italiana foi definida por Leonardis, Mauri \& Rotelli (1995, p.13):

A empresa social é uma estratégia de transformação dos aparatos administrativos e de organização da assistência que se propõe a investir nos recursos materiais e humanos que se depositam sobre ela, começando pelos recursos dos destinatários da assistência. Ampliando, portanto, os espaços de ação do mercado e as possibilidades de empreendimento, de trabalho e de intercambio social.

\footnotetext{
17 Um dos serviços territoriais "inventados" pela Psiquiatria Democrática Italiana para responder ao desafio da inversão da lógica do trabalho institucional e dependente no campo da saúde mental.
} 
Nesse modelo, a cooperativa social tornou-se um dispositivo privilegiado de uma rede complexa de serviços, que são considerados ao mesmo tempo como serviços de tratamento e lugares de produção, integrando sócios "normais" e "inabilitados" (Leal, 2004, p. 19).

Essa discussão vem sendo promovida pelos movimentos dos usuários tanto nos EUA como na Europa, e se caracteriza pela heterogeneidade de posições: enquanto alguns criticam as cooperativas exclusivas de usuários, que avaliam manterem a segregação dos pacientes, outros defendem direitos especiais como o "salário subsidiado", que possibilita ao empregador o recebimento de subsídios estatais para o pagamento de salários comuns aos deficientes (Vasconcelos, 2000).

No contexto brasileiro o debate se dirige à natureza da utilização do trabalho na saúde mental: trabalho terapêutico ou trabalho reabilitadoremancipador. No primeiro caso, os autores defendem que o trabalho exerce uma função fundamental na promoção da saúde e do adoecimento e, que no caso dos pacientes psiquiátricos, não há como negar as alterações psicopatológicas específicas que devem ser consideradas nas experiências de trabalho. Para eles, interessa a subjetividade e a singularidade do louco. Defendem um uso mais clínico e menos sociopolítico do trabalho na saúde mental (Guerra, 2000). Por outro lado, os autores que negam a utilização do trabalho como terapia, propondo seu uso como forma de garantia de remuneração e de contratualidade, discutem a vocação terapêutica e sua relação com a manutenção do sistema social, apontando que o trabalho é um direito do cidadão e não pode ser transformado em tratamento (Rotelli, 1998).

Para Basaglia, por exemplo, o ato terapêutico revela-se como um ato político de integração (apud Guerra, 2000). Aqui se trata de promover a cidadania e a valorização social dos sujeitos (Basaglia, Gallio, 1991). Mas há também aqueles que defendem uma combinação das duas possibilidades, buscando "entrelaçar a subjetividade com a cidadania, ou seja, entrelaçar o sujeito em suas dimensões psíquicas com o sujeito em suas dimensões políticas, as oficinas irão se inserir justo na interseção entre esses dois campos" (Guerra, 2000, p. 54). 
Outro debate que se insere na discussão do trabalho no campo da saúde mental brasileira diz respeito à forma de organização dessas experiências quer seja em oficinas e projetos de trabalho protegidos ou em cooperativas sociais, destinadas exclusivamente aos usuários ou integrando outras pessoas em desvantagem social, ou mesmo pessoas "normais".

Até $\mathrm{o}$ ano de 2006, segundo dados do Ministério da Saúde ${ }^{18}$, existiam 239 experiências de inclusão social pelo trabalho no Brasil, que foram mapeadas pelo Grupo de Trabalho de Saúde Mental e Economia Solidária, instituído pela Portaria Interministerial $n^{0} 353$ de 7 de Março de 2005. Entretanto em sua maioria estas se caracterizam pela frágil sustentação institucional e financeira (Brasil, 2006).

Ao final de 2004, o Programa de Saúde Mental do Ministério da Saúde e a Secretaria Nacional de Economia Solidária se reuniram para dialogar acerca da "reinserção social e econômica das pessoas com transtornos mentais", o que resultou na criação do Grupo de Trabalho e numa linha específica de financiamento destinada aos municípios que desenvolvem atividades de inclusão econômica para essa população. Desde então se constituiu uma parceria entre o campo da saúde mental e da economia solidária com objetivo de garantir o direito ao trabalho.

Como já dissemos, o movimento da Economia Solidária surgiu como uma resposta alternativa às transformações no mundo do trabalho que geraram grandes massas de desempregados e excluídos, seguindo a tendência européia. A partir da década de 1990, a abertura econômica do Brasil aos mercados internacionais, à chamada globalização, resultou em impactos negativos no mundo do trabalho. A entrada de produtos importados, somada às altas cargas tributárias e à exigência de evolução tecnológica para competir com os produtos estrangeiros, culminaram no fechamento de muitas empresas nacionais e no estabelecimento de grandes monopólios multinacionais. Tais fatores associados às novas formas de organização do trabalho e aos processos de reestruturação produtiva, bem como as crescentes precarizações das relações de trabalho foram os

${ }_{18}$ A esse respeito ver publicação do Ministério da Saúde intitulada Saúde Mental e Economia Solidária: inclusão social pelo trabalho. (Brasil, 2006) 
responsáveis pelo aumento do desemprego, do sub-emprego e da exclusão de grandes parcelas da população do ciclo produtivo. Nessa população estão não apenas os deficientes, os loucos, mas as pessoas idosas, desempregados de longa duração, jovens, mulheres, minorias étnicas ou de cor, sequelados de doenças físicas e/ou acidentados (Alcântara, 2007).

A Economia Solidária como política pública é um processo em construção no Brasil, fruto da expansão da democracia e da luta pela cidadania no país. Após a década de 1990, muitas experiências municipais e estaduais de empreendimentos solidários foram se desenvolvendo nas comunidades indígenas, nos assentamentos da reforma agrária, na recuperação de grandes empresas e recentemente nos projetos de inclusão social pelo trabalho do campo da saúde mental (Schiochet, 2005).

A concepção de Economia Solidária está expressa no parágrafo abaixo, formulado por um dos seus principais representantes, o autor Paul Singer.

A economia solidária foi concebida como um modo de produção que tornasse impossível a divisão da sociedade em uma classe proprietária dominante e uma classe sem propriedade subalterna. Sua pedra de toque é a propriedade coletiva dos meios de produção (além da união em associações ou cooperativas de pequenos produtores). $\mathrm{Na}$ empresa solidária, todos que nela trabalham são seus donos por igual, ou seja, têm os mesmos direitos de decisão sobre o seu destino. $E$ todos os que detêm a propriedade da empresa necessariamente trabalham nela (Singer, 2005, p. 14).

Nesse sentido, os pensadores desse campo definem a economia solidária como uma alternativa de produção ao modo de produção capitalista, pois se baseiam numa organização mais igualitária sem divisão entre proprietários e trabalhadores, na valorização do ser humano pela solidariedade, pela cooperação e pela auto-gestão. Sua intenção não é o lucro como numa empresa capitalista, mas a inclusão social.

O encontro do movimento da Reforma Psiquiátrica com o movimento da Economia Solidária apontou para a perspectiva de criação de empreendimentos solidários destinados à inclusão social pelo trabalho dos usuários da saúde mental, egressos ou não dos manicômios, excluídos de longa data ou por ocasião de manifestações de sofrimento mental do mercado formal de trabalho. O objetivo de ambas políticas é a transformação 
de conceitos e comportamentos sociais diante da mesma população excluída (Alcântara, 2007).

É sabido que na Psiquiatria Democrática Italiana, a criação de cooperativas foi essencial para o desenvolvimento da lógica do trabalho antiinstitucional como forma concreta de solidariedade e cooperação; e de subversão da finalidade terapêutica na medida em que os pacientes puderam se constituir como sócios. Nessa experiência, tratava-se de desinstitucionalizar o próprio trabalho, de separar o par trabalho/salário, oferecendo um lugar de promoção da autonomia e de proteção, não apenas a partir da produção material, mas da sociabilidade e subjetividade, envolvendo os usuários de maneira ativa em sua possibilidade de produzir, criar e consumir; para que deixem de ser destinatários passivos da assistência e se tornem então, produtores de competência, ou seja, de recursos (Saraceno, 2001).

Logo, as cooperativas de trabalho italianas possibilitavam 0 estabelecimento de uma relação menos alienada do usuário com a própria produção e o reconhecimento do justo valor do trabalho, por meio da sua participação ativa de todas as fases do trabalho cooperativo, caso contrário, prescindindo da contribuição dos usuários, a equipe técnica estará agindo de forma paternalista, sem assumir na prática e integralmente o discurso de reconquista da cidadania que teria como principal agente o próprio usuário (Delgado,1991).

Outro aspecto fundamental à finalidade emancipatória do sentido do trabalho nas cooperativas, trata-se do nascimento da cooperativa que deveria ser resultante dos movimentos e anseios dos usuários que "vislumbram nesta estrutura a oportunidade de construir algo produtivo, não deveria corresponder aos desejos de técnicos ou administradores, desejo este que reflete uma organização vertical de poder" (Delgado, 1991, p. 20).

O sentido da utilização do trabalho nas estruturas cooperadas, na citação abaixo, corrobora com essa concepção:

Com as cooperativas ou empresas sociais ou mesmo com projetos de geração que incorporam os mesmos princípios das anteriores, a questão do trabalho foi alvo de uma reviravolta. $O$ trabalho deixa de ser uma atividade terapêutica (prescrita, orientada, protegida), ou deixa de ser uma forma de simples ocupação do tempo ocioso, ou, 
ainda, uma forma de submissão e controle institucional para se tornar uma estratégia de cidadania, de autonomia e emancipação social (Amarante, 2007, p.92).

Entretanto, no Brasil, existem algumas dificuldades para a criação de cooperativas sociais no campo da saúde mental, especialmente no que diz respeito à questão da lei do cooperativismo social, que precisa ser revisitada e regulamentada:

A necessidade de tutela ou curadoria de alguns oficineiros, a alta carga tributária das cooperativas, a perda de benefícios previdenciários ao se tornarem cooperados, a delimitação da população que impede pessoas que não se encaixam nos grupos em situação de desvantagens sociais, têm sido impeditivos para a fundação formal de cooperativas sociais na Saúde Mental (Alcântara, 2007, p. 178).

Outra problemática relaciona-se à carga tributária das cooperativas sociais que são similares à de uma empresa convencional, e conforme a Lei do cooperativismo, cerca de $35 \%$ da arrecadação total deve ser destinada ao pagamento de impostos e composição de fundos, o que gera uma inviabilização dos projetos de geração de renda e trabalho no campo da saúde mental, pois a renda gerada ainda é insuficiente, não atingindo o custo de produção e tributação de uma empresa comum (Alcântara, 2007).

Atualmente com a discussão e desenvolvimento de projetos de inserção laborativa que utilizam o trabalho como recurso reabilitador, como projetos e oficinas de geração de renda e trabalho, associações e cooperativas, se faz necessário problematizar a natureza dessas iniciativas, tendo em vista a preocupação de não incorrer na mesma lógica manicomial, moral, terapêutica, explorador e normatizante da utilização do trabalho pelas propostas reabilitadoras e o desafio de oferecer oportunidades de trabalho que possam restituir a potencialidade e valorização (contratualidade) dos usuários sem reproduzir em nível particular as relações de poder e dependência das instituições e em nível estrutural os efeitos alienantes do processo de trabalho no modelo capitalista.

A garantia do direito ao trabalho é uma das questões centrais nos processos de construção de contratualidade, de protagonismo e de um novo lugar social para as pessoas com transtornos mentais e/ou com transtornos associados ao consumo de álcool e outras drogas, que se constitui numa 
tarefa delicada e complexa que exigirá, nos próximos anos, o empenho no diálogo e articulação com diversos atores e recursos do território para a efetiva produção de empreendimentos econômicos solidários e inclusivos das pessoas em situação de vulnerabilidade, no contexto das políticas públicas promotoras de desenvolvimento local e inclusão social (Brasil, 2007).

Partindo do pressuposto de que a cooperativa social seja uma das alternativas de inclusão por meio do trabalho que se destaca pela pretensão de transformar as relações de produção a partir de princípios como a autogestão, a associação e cooperação mútua, a solidariedade, o respeito às diferenças das pessoas em desvantagem social, pretendemos estudar a relação entre cooperativa social e saúde mental no contexto das reformas psiquiátricas, analisando as experiências que buscaram ou buscam desenvolver iniciativas de empreendimentos solidários e cooperativados, identificando suas possibilidades e dificuldades.

Portanto o objeto deste estudo são projetos de geração de renda e trabalho que pretendem se configurar como cooperativas sociais, consideradas estratégias de Reabilitação Psicossocial no contexto da desinstitucionalização. Para tal, buscamos articular os estudos sobre essa temática na literatura científica com a análise da experiência concreta das Oficinas de Trabalho do Núcleo de Trabalho do Serviço de Saúde Dr. Cândido Ferreira.

Assim, esta pesquisa tem por finalidade contribuir com a discussão sobre as cooperativas sociais como estratégias de reabilitação psicossocial no eixo trabalho, dentro do contexto do processo da desinstitucionalização no campo da Reforma Psiquiátrica Brasileira, refletindo criticamente sobre o processo de trabalho cuja finalidade refere-se à reabilitação psicossocial e sobre o sentido do trabalho como estratégia de inclusão social.

Para apreender esta realidade os objetivos delineados foram:

- Analisar os conceitos sobre Reabilitação Psicossocial, Trabalho e Cooperativa Social dos coordenadores de um Programa de geração de rendas para usuários de serviços de saúde mental à luz da proposta de desinstitucionalização; 
- Identificar os elementos simples constitutivos da organização do processo de trabalho no Núcleo de Oficinas e Trabalho.

- Identificar os limites e possibilidades da transformação do projeto de trabalho em cooperativas sociais no campo da saúde mental no sentido de constituir-se numa alternativa de trabalho cooperado às pessoas em desvantagem social. 
PERCURSO METODOLÓGICO 


\section{PERCURSO METODOLÓGICO}

Pesquisador e pesquisado se definem por relações sociais que tanto podem ser reprodutoras como podem ser transformadoras das condições sociais onde ambos se inserem; desta forma, conscientes ou não, sempre a pesquisa implica intervenção, ação de uns sobre os outros (Lane,1989).

Este estudo foi realizado como pesquisa qualitativa, uma vez que o objeto estudado corresponde aos projetos de geração de renda e trabalho no campo da saúde mental, temática de cunho social que, portanto, considera a realidade determinada por inúmeros aspectos. A pesquisa qualitativa, nesse sentido, permite incorporar os aspectos históricos, culturais e ideológicos trazidos pelo tema que não pode ser contido apenas numa fórmula numérica ou num dado estatístico (Minayo, 1994).

No que diz respeito ao nível de abrangência no enquadramento do objeto esta é uma pesquisa focal simples, que elege como objeto uma temática específica e empírica com objetivo de contribuir para o debate teórico e técnico do tema (Vasconcelos, 2002).

A categoria de pesquisa qualitativa utilizada foi o Estudo de Caso, cujo objetivo é análise em profundidade de uma unidade. O Estudo de Caso favorece o conhecimento de uma realidade delimitada e seus resultados podem permitir e formular hipóteses para o encaminhamento de outras pesquisas (Triviños, 1987).

A pesquisa é compreendida como uma atividade básica das Ciências na sua indagação e construção da realidade, sendo $o$ ato de pesquisar uma atividade de ensino, que se caracteriza por uma atitude e uma prática constante de busca teórica, de "aproximação sucessiva da realidade que nunca se esgota, fazendo uma combinação particular entre teoria e dados, pensamento e ação" (Minayo, 2006, p.47). Seu caráter de provisoriedade também define a Pesquisa Social, uma vez que por tratarem de temas relacionados ao ser humano em sociedade, suas relações e instituições, estão condicionadas à historicidade e à totalidade, compreendendo todas as contradições e conflitos que caracterizam a realidade objetiva. No campo das investigações no campo da saúde coletiva, é possível juntar consistência teórica e relevância social, já na construção do projeto, prevendo os produtos 
que se pretende construir e direcionando os resultados de forma operacional. Para tal se faz necessário escolher os métodos de acordo com o tipo de abordagem da realidade e os objetivos do trabalho (Minayo, 2006).

\section{Referencial teórico metodológico e categorias de análise}

Em nosso estudo, utilizaremos como metodologia de investigação científica a abordagem dialética marxista, fundamentada principalmente na obra de Marx e dos marxistas, devido ao seu caráter de abrangência da totalidade dentro da perspectiva histórica e dialética das relações entre 0 indivíduo e a sociedade.

Dada a ênfase que Marx colocava ao trabalho humano como central no desenvolvimento histórico da humanidade e suas relações com a natureza e entre os homens, a escolha pela abordagem dialética como método vai de encontro ao objeto de estudo da presente pesquisa, uma vez que no campo da Reforma Psiquiátrica, a discussão da inserção social pelo trabalho pressupõe o debate entre o potencial emancipatório (reabilitador) ou alienante (terapêutico-explorador) do trabalho nos projetos de geração de renda e trabalho, que almejam configurar-se como cooperativas sociais. Esse sentido do trabalho, na concepção marxista, não se manifesta apenas no resultado do trabalho, mas também no interior do processo de produção, na organização e desenrolar do processo de trabalho.

A teoria marxista busca compreender as transformações ocorridas no trabalho e suas conseqüências na vida humana e na organização social, que não são dadas a priori nem são naturais, mas sim permeadas de conflitos e contradições num processo de constantes transformações históricas.

Para os marxistas, a história "não é uma unidade vazia ou estática da realidade, mas uma totalidade dinâmica de relações que explicam e são explicadas pelo modo de produção concreto" (Minayo, 2006, p. 111). O princípio da totalidade está relacionado ao fato de que o particular não tem existência senão vinculado ao geral, aos processos e fenômenos mais gerais que determinam a realidade objetiva. Em outras palavras, busca-se compreender e analisar as partes do todo, que com ele se relaciona e estabelece conexões; todo este relacionado à estrutura social, política e 
econômica. Nesse sentido, para os materialistas dialéticos, não é possível conhecer as partes sem conhecer o todo, nem conhecer o todo sem conhecer as partes, e esta relação entre singular e universal, entre particular e o geral está permeada de contradições e de intercâmbios.

Sendo assim, não é possível compreender o uso do trabalho e suas contradições nos projetos de geração de rendas sem articulá-los com a totalidade social em que está inserido, isto é, a própria instituição e as políticas públicas do município, bem como as principais características do trabalho no modo de produção capitalista.

A sociedade, para os marxistas, é concebida como uma totalidade dinâmica determinada materialmente:

\footnotetext{
Segundo a concepção materialista da história, o fator que, em última instância, determina a história é a produção e a reprodução da vida real [...] Se alguém o modifica, afirmando que o fato econômico é o único fato determinante, converte aquela tese numa frase vazia, abstrata e absurda (Engels, 1980, p. 284).
}

$\mathrm{Na}$ formulação marxista, a situação econômica é a base, mas os diferentes fatores da superestrutura que se levantam sobre ela exercem influência sobre o curso da história e muitas vezes determinam sua forma, como fator predominante. Os elementos da superestrutura que são as formas jurídicas, políticas e formas de consciência social estabelecem um jogo recíproco de ações e reações entre si que acaba sempre por impor-se, como necessidade, o movimento econômico, ou seja, a forma como em cada época os seres humanos se relacionam para produzir sua existência a partir de certas condições materiais. Isso quer dizer que as instituições e suas representações ideológicas, jurídicas, sociais, políticas e culturais são determinadas pelos meios de produção e as relações sociais de produção da sociedade (Engels, 1890). Portanto, a instituição psiquiátrica está inserida nessa totalidade e o trabalho nessas instituições, como forma particular, é determinado também pela forma de trabalho que se universalizou em uma dada sociedade, no caso brasileiro, a forma capitalista de mercadoria. Estas dimensões se articulam entre si e estão em constante relação dialética de contradições e conflitos.

A primeira lei da dialética refere-se à compreensão da realidade como algo em constante transformação, fruto de conflitos e contradições derivadas 
dos antagonismos entre as classes sociais, no processo de produção e reprodução social. O todo, portanto, é uma unidade de luta dos contrários, que mesmo em oposição são inseparáveis, estão em relação recíproca. Essa lei, a lei da interpenetração dos contrários, é comumente denominada lei da unidade e luta dos contrários (Egry, 2006).

A lei da passagem da quantidade à qualidade e inversamente revelase na condição que "na natureza, de uma maneira claramente determinada para cada caso particular, as transformações qualitativas só podem ter lugar por adição ou subtração quantitativas de matéria ou de movimento" (Engels, s/d, p.50). Isto quer dizer, que no processo de transformação, as mudanças qualitativas ocorrem por meio de um salto, quando as sucessivas mudanças quantitativas vão se somando e provocam, dado momento, a passagem da velha qualidade para a nova: "o ser passa a ser outro" (Egry, 2006, p.71).

$\mathrm{Na}$ lei da negação da negação, "o salto dialético implica simultaneamente a continuidade (o movimento profundo que continua) e a descontinuidade (o aparecimento do novo, o fim do antigo)" Trata-se do movimento em espiral da superação, isto é, "o retorno acima do superado para dominá-lo e aprofundá-lo, para elevá-lo de nível libertando-o de seus limites (de sua unilateralidade)" (Lefebvre, 1979, p.239-40). Isto quer dizer que cada nova qualidade nega a anterior, mas ao negá-la e superá-la também conserva dela seu resultado positivo anterior.

Estas três leis constituem as leis fundamentais da dialética, como leis gerais do movimento da realidade, do devir universal (Lefebvre, 1979, p. 240):

O acento pode ser colocado, alternadamente, sobre essa ou aquela
lei. Em certos casos, a lei da contradição parecerá mais essencial,
pois na contradição encontra-se a raiz, o fundamento de todo
movimento. Mas as próprias contradições, em certo sentido,
resultam de um movimento profundo, que as condiciona e as
atravessa! E nesse sentido, o acento será colocado sobre a lei da
conexão, da interdependência universal. Ou ainda, se estuda uma
metamorfose ou uma crise, a lei dos saltos passará ao primeiro
plano. Pouco importa. Os aspectos do devir são igualmente
objetivos e indissoluvelmente ligados no próprio devir.

O princípio da união dos contrários está presente nas totalidades em vários momentos de relações e conflitos: entre a aparência e essência do fenômeno e entre as leis e o fenômeno; entre o singular e o universal, entre 
o particular e o geral, entre a base material e a consciência, entre teoria e prática, entre o objetivo e o subjetivo, entre indução e dedução (Minayo, Egry, 2006).

Neste estudo, a compreensão da relação dialética entre a aparência e a essência do fenômeno fundamentou a análise sobre o processo de trabalho cooperado (fenômeno) nas oficinas de geração de rendas (aparência), buscando apreender dos discursos o sentido do trabalho (essência) nestas experiências. A aparência é um aspecto da coisa em si, não a coisa inteira, e se manifesta no fenômeno, que é, por sua vez, o meio através do qual a essência se realiza, onde ela se revela. Portanto para se compreender a essência devemos partir da sua aparência, manifesta no fenômeno, buscando o fenômeno característico, o essencial, chegando à coisa em si, como uma totalidade de relações e manifestações. A partir do movimento do conhecimento que vai penetrando no nível mais profundo busca-se, portanto, a totalidade da coisa, a coisa em si, o real concreto, a essência.

Nesse sentido, buscamos investigar a essência subjacente ao fenômeno e à sua aparência, revelada pelo discurso. O discurso revela 0 real e o real é revelado pelo discurso, portanto, constituem uma unidade indissolúvel. Por ser revelador, o discurso mesmo se configura como um aspecto do real que está descrevendo (Kojève, 2002). Sendo assim, o discurso dos coordenadores que definem (e qualificam) o processo de trabalho nas oficinas de trabalho pode refletir o próprio real, ou seja, a utilização do trabalho seja como trabalho alienado (ou terapêutico) nos limites próprios da instituição, que inserida numa estrutura geral, reproduz uma função social de controle e manutenção da ordem, ou como trabalho emancipado (ou reabilitador) que pretende configurar-se como uma nova qualidade, superando o paradigma psiquiátrico pela desinstitucionalização e subvertendo o processo de exclusão social da qual foram vítimas as pessoas com sofrimento mental.

No pensamento marxista, a categoria básica de análise da sociedade é o modo de produção historicamente determinado e a categoria mediadora das relações sociais é o trabalho, que se caracteriza pela ação humana: a 
práxis, que ao mesmo tempo determina a história e é determinado por ela. É na práxis humana que está a possibilidade das transformações no sentido da emancipação (Minayo, 2006). A categoria analítica utilizada para balisar a análise dos dados deste estudo é Trabalho, considerando também os conceitos de alienação, de emancipação humana e de processo de trabalho, visando uma articulação com os pressupostos da desinstitucionalização e da reabilitação psicossocial, na perspectiva da criação de cooperativas sociais como uma opção de trabalho cooperado e emancipado, que pretende romper com a lógica do trabalho terapêutico e institucional, constituindo-se numa alternativa de trabalho menos alienante e mais independente aos usuários de saúde mental.

\subsubsection{Trabalho como categoria analítica}

O trabalho é a fonte de toda a riqueza, afirmam os economistas. Assim é, com efeito, ao lado da natureza, encarregada de fornecer os materiais que ele converte em riqueza. $O$ trabalho, porém, é muitíssimo mais do que isso. É a condição básica e fundamental de toda a vida humana. E em tal grau que, até certo ponto, podemos afirmar que o trabalho criou o próprio homem.

Friedrich Engels.

$\mathrm{Na}$ sociedade contemporânea, o mundo do trabalho tem sofrido grandes transformações: o crescimento do desemprego, a intensa fragmentação do mercado de trabalho, as evoluções tecnológicas, a constante precarização das relações trabalho, as terceirizações e quarteirizações, entre outras, levou alguns autores como Offe, Benjamin Coriat, Mandel, Kurz, Habermas, Harvey, e outros, a decretarem o fim da centralidade do trabalho, o fim do proletariado e o fim da história (Organista, 2006).

Não pretendemos no presente texto debater com profundidade a questão da centralidade do trabalho na organização social contemporânea por tratar-se de um dos temas mais complexos das ciências humanas. A intenção deste estudo é fazer brevíssimas considerações acerca da importância do trabalho na vida humana, na história dos homens como elemento estruturador e produtor de sentidos na vida concreta das pessoas. Nosso objetivo é apresentar alguns pontos acerca da categoria trabalho e 
sua relação com a organização social (dimensão estrutural), com destaque para as expressões particulares do trabalho, que para nós interessa na análise do uso do trabalho pelos projetos de inclusão social: o trabalho alienado e o trabalho emancipado.

No momento em que o movimento da Reforma Psiquiátrica define como fundamental o direito ao trabalho, a potencialização do trabalho como recurso de reabilitação psicossocial e de inclusão social às pessoas com sofrimento psíquico, faz-se necessário problematizar de que trabalho se trata, para que, como, em que condições e sob quais relações esse trabalho deverá se realizar. E ainda num país onde o desemprego e o subemprego atingem importantes parcelas da sociedade, podemos ainda falar de inclusão social a partir do trabalho? Para tentar responder estas questões sem a pretensão de esgotá-las, mas com o intuito de manter em aberto o debate, buscaremos resgatar alguns conceitos clássicos sobre o trabalho à luz do materialismo histórico dialético.

Para os materialistas dialéticos, a sociedade se constitui a partir de condições materiais de produção e da divisão social do trabalho. Os seres humanos, diferenciam-se dos animais não por serem dotados de consciência, nem por serem naturalmente sociáveis e políticos, mas por serem capazes de produzir as condições de sua existência material e intelectual. Mas a produção dessas condições materiais e intelectuais de existência são historicamente determinadas e independem da vontade dos homens (Chauí, 2000).

O papel do trabalho é determinante na história da humanidade, desde os seus primórdios, desde a transição do macaco ao homem há milhares de anos. Nesse período, o papel das mãos foi essencial na adoção de uma postura mais ereta e posteriormente na execução de funções cada vez mais variadas até a elaboração de instrumentos. Nesse sentido, o desenvolvimento da utilização das mãos no domínio da natureza, deve-se ao trabalho, o que levou Engels (s/d, p. 270) a afirmar que "a mão não é apenas o órgão do trabalho; é também produto dele".

É, sobretudo, graças à cooperação da mão, dos órgãos da linguagem e do cérebro, desenvolvidas em toda a sociedade, que os homens foram 
aprendendo a executar operações cada vez mais complexas e atingir objetivos cada vez mais elevados. O trabalho foi se diversificando e aperfeiçoando de geração em geração, estendendo-se cada vez mais a novas atividades. Às atividades de coleta e caça somou-se a agricultura, mais tarde a fiação e a tecelagem, a elaboração de metais, a olaria e a navegação. Em seguida ao lado do comércio e dos ofícios, surgiram as artes e as ciências. Das tribos nasceram as nações e os Estados, o direito e a política e com eles, a religião (Engels, s/d).

Frente a todas essas criações, que se manifestavam em primeiro lugar como produtos do cérebro e pareciam dominar as sociedades humanas, as produções mais modestas, fruto do trabalho da mão, ficaram relegadas a segundo plano, tanto mais quanto numa fase muito recuada do desenvolvimento da sociedade (por exemplo, já na família primitiva), a cabeça que planejava o trabalho já era capaz de obrigar mãos alheias a realizar o trabalho por ela (Engels, s/d, p. 275).

O progresso da civilização foi exclusivamente atribuído ao desenvolvimento do cérebro; os homens passaram a explicar seus atos pelos pensamentos ao invés de buscar essa explicação em suas necessidades (que refletidas na cabeça, fazem com que o homem tome consciência delas). Foi daí que se originou a concepção idealista do mundo que ignora e obscurece o papel desempenhado pelo trabalho no desenvolvimento da humanidade e que perdura até os dias atuais, dando origem à valorização do trabalho intelectual em detrimento ao trabalho manual (Engels, s/d).

Para os materialistas históricos, o trabalho só pode ser compreendido como parte do processo de reprodução da sociedade, isto é, como parte de uma totalidade social. Só pode ser considerado um ato de trabalho concreto singular apenas na relação com a totalidade social.

\footnotetext{
Articulados com a totalidade social, descobertas as suas conexões com a reprodução social, todos os atos de trabalho, em sua infinita distinção, exibem a função social deles fundante: a transformação da natureza nos bens materiais indispensáveis à reprodução de cada sociedade (Lessa, 2005, p. 77).
}

Sendo assim, o trabalho, é para os marxistas, categoria fundante do mundo humano, pois a história dos homens é a história das relações sociais, dos diversos modos de produção, das diferentes maneiras em que o homem se organizou para transformar a Natureza. E esse desenvolvimento do 
trabalho se estende a todas esferas do ser social, desde a economia até a particularidade mais íntima dos indivíduos (Lessa, 2005).

Para os marxistas, a produção e reprodução das condições de existência se realizam a partir do trabalho (relação com a Natureza), da divisão social do trabalho (intercâmbio e cooperação), da procriação (sexualidade e família) e do modo de apropriação da Natureza (propriedade). Estes fatores são os que determinam, em cada período, os modos de produção da sociedade (Chauí, 2000).

O desenvolvimento das chamadas forças produtivas, isto é, da capacidade dos homens transformarem a natureza com um gasto menor de horas de trabalho, repercutem na sucessão de modos de produção ao longo da história da humanidade. A descoberta da agricultura e a Revolução Industrial são dois grandes marcos dos saltos fundamentais no desenvolvimento das forças produtivas: o primeiro porque possibilitou o surgimento do trabalho excedente e o segundo, pois permitiu a superação da força física humana a partir da aplicação de energia mecânica à produção (Lessa, 2005).

A passagem da sociedade primitiva à sociedade de classes introduziu mudanças enormes especialmente no trabalho, que passou de expressão imediata das necessidades humanas à necessidade de reprodução da sociedade de classes. Nesse processo histórico, passou de trabalho escravo, para feudal e depois para trabalho abstrato, forma particular do capitalismo, que difere das anteriores, por ser uma forma de exploração do homem pelo homem a partir de uma relação assalariada, que não opera o intercâmbio orgânico com a natureza. $O$ que funda o trabalho abstrato é a forma de riqueza particular da sociedade burguesa: o capital, que se reproduz não pela transformação da natureza, mas pela produção de maisvalia e pela conversão da força de trabalho em mercadoria no modo de produção capitalista.

Dessa maneira, "o trabalho, portanto, para Marx, é a expressão da vida humana e através do trabalho, o homem transformou-se a si mesmo" (Fromm, 1983, p. 26). 
Alguns autores estudaram a relação entre trabalho e saúde, e mais especificamente saúde mental, sob diferentes óticas e aspectos. Para Dejours (1991), por exemplo, não existe neutralidade entre trabalho e saúde mental, podendo favorecer tanto a saúde como a doença. O sofrimento físico, social e psíquico advindo do trabalho é estudado por muitos autores e teorias. Neste estudo, buscamos compreender a importância do trabalho na vida humana, em especial para os sujeitos que historicamente foram considerados incapazes de produzir, e por esta razão, excluídos da sociedade. Nesse sentido, interessa-nos analisar o qual sentido da utilização do trabalho nas propostas de inclusão social, especialmente nos projetos que pretendem se organizar ou se pautar pelos princípios do cooperativismo social. De que trabalho se trata, para que, como, em que condições e sob quais relações esse trabalho deverá se realizar? Estas questões dizem respeito à discussão dos elementos do processo de trabalho, que segundo a concepção materialista dialética, também é determinado pelas transformações históricas do modo de produzir.

Em sua obra, Marx discute a relação do trabalho com a alienação (trabalho alienado) e com a emancipação humana (trabalho emancipado), que se expressam também no próprio processo de trabalho. Estes conceitos importantes ao estudo em questão são definidos a seguir.

\section{a) Alienação}

A alienação, para Marx, é um construto histórico, resultado das relações sociais de produção do sistema capitalista. Esta temática foi desenvolvida principalmente nos Manuscritos de 1844. O conceito de alienação em Marx, que se diferencia e supera tanto o de Hegel (que por sua vez tomou emprestado de Pinel) como o de Feuerbach, significa "o processo por meio do qual a essência humana dos operários se objetivava nos produtos do seu trabalho e se contrapunha a eles por serem produtos alienados e convertidos em capital" (Gorender, apud Tumolo, 2007, p. 3).

A noção de alienação, para os marxistas, portanto está vinculada ao trabalho no modo de produção capitalista, na medida em que: 
A sociedade capitalista caracteriza-se pela apropriação privada do trabalho coletivo e pela distribuição desigual dos produtos desse trabalho. O trabalho é coletivo enquanto produção e é privado enquanto apropriação. A apropriação do trabalho humano e seus excedentes é a base da alienação (Mângia, 2003, p. 40).

O trabalho alienado, por sua vez, caracteriza-se por ser resultante da transformação do trabalho em algo vendável, em mercadoria. A venda da força de trabalho e a apropriação do produto de trabalho por outro, modifica o sentido do trabalho, antes utilizado para a satisfação das necessidades do homem, adquirindo um valor de mercadoria, que por sua vez desumaniza o homem.

Assim, "o trabalho não produz apenas mercadorias; produz também a si mesmo e ao trabalhador como mercadoria, e justamente na mesma proporção que produz bens" (Marx, 1844, p. 159, grifos do autor).

O fato é que o objeto produzido pelo trabalho aparece ao trabalhador como um objeto estranho porque este não lhe pertence, mas pertence a outro, é apropriado por outro. E quanto mais produzir, menos ele pode possuir, sujeitando-se ao domínio do seu produto, ao domínio do capital. A apropriação do produto do trabalho tornou-se alienação, mas esta última não se revela apenas no resultado do trabalho, configurando-se também no próprio processo da produção. (Marx, 1844).

Marx também distingue algumas dimensões da alienação, distintas entre si, como a objetivação, externação e estranhamento (lasi, 2006):

O produto do trabalho é o trabalho que se fixou num objeto, que se transformou em coisa física, é a objetivação do trabalho. A realização do trabalho constitui simultaneamente sua objetivação [...] A alienação do trabalhador no seu produto significa não só que o trabalho se transforma em objeto, assume uma existência externa, mas que existe independentemente, fora dele e a ele estranho, e se torna um poder autônomo em oposição com ele; que a vida que deu ao objeto se torna uma força hostil e antagônica (Marx, 1844, p. 159-160, grifos do autor).

O trabalho alienado, portanto, ao retirar do homem seu produto, também retira sua vida genérica, sua atividade própria de produzir e reproduzir o mundo humano e de objetivar-se nesse mundo. No trabalho alienado, o homem também se vê alienado da natureza, de si mesmo, de seu ser genérico e dos outros homens (Mângia, 2003). 
b) Emancipação Humana

Para Marx, a questão da emancipação humana se realiza a partir da emancipação do trabalhador, quando o trabalho alienado for superado, e o trabalho constituir-se como práxis $^{19}$. Nesse sentido, afirma que "toda emancipação humana constitui uma restituição do mundo humano e das relações humanas ao próprio homem" (Marx, apud lasi, 2007, p. 48).

Segundo os marxistas, são os seres humanos concretos, inseridos em relações sociais determinadas, que fazem a história, mas não a fazem como querem, pois estão determinados pelas circunstâncias e pela base material da sua realidade objetiva, esta também resultante de ações humanas passadas. Estas condições também determinam sua consciência social. Sendo assim, a possibilidade de emancipação humana se dá quando os seres humanos possam assumir o controle consciente de sua existência, superando as mediações que o impedem de ver a história como fruto da ação humana (lasi, 2007).

É por meio do trabalho, protoforma da práxis humana, que o homem não apenas modifica a Natureza, transformando-a em valores de uso capazes de satisfazer sua necessidade, mas também modifica a si próprio. 0 homem torna-se um ser que trabalha e modifica o mundo, e este mundo modificado pelo trabalho se apresenta externado numa realidade objetiva, na forma de objetos, relações sociais, instituições, que são frutos da ação humana, mas mostram-se como objetivos, externos, e como estranhos, voltando-se contra os homens e subjugando-os, ao invés de serem os homens a dominá-los.

A superação dessa alienação, segundo Marx, só pode acontecer mediante condições práticas, mediante a alteração das circunstâncias que determinam essa alienação: a mercadoria, o capital e o Estado.

A emancipação humana, na concepção marxista, pressupõe essencialmente a superação do modo de produção capitalista e suas características, divisão social do trabalho, a propriedade privada dos meios de produção, exploração e domínio do capital sobre a classe trabalhadora,

\footnotetext{
${ }^{19}$ Para um estudo esclarecedor da concepção marxista de emancipação, que se distingue radicalmente de outras vertentes teóricas, ver lasi (2007).
} 
entre outros, que estrutura a organização social e suas instituições. Trata-se de uma transformação na totalidade, no nível estrutural, em direção à construção de um novo modo de produção fundamentado na socialização dos meios de produção.

Entretanto essa transformação não ocorre de maneira instantânea, mas é resultante dos processos de mudanças desenvolvidos pelos seres humanos, que ao se conscientizarem da realidade enquanto fruto de determinações sociais e históricas e de seu papel de sujeito histórico por meio da práxis, assumem como dever coletivo a superação das condições objetivas que bloqueiam a satisfação de suas necessidades humanas, constituindo-se como um sujeito coletivo que necessita então superar o todo (Gonçalves, 1992).

Sendo assim, a superação da alienação dos trabalhadores pela práxis pressupõe a sua conscientização sobre o trabalho como satisfação de suas necessidades não-alienadas e sobre os processos de trabalho que vão ao encontro dessas necessidades reais.

No campo próprio da saúde mental, a construção de novos modelos deverá necessariamente explorar as contradições inerentes aos fenômenos, desde a mera denúncia até a verificação das formas positivas de sua superação tendencial. A construção desse sujeito coletivo, desse novo homem, passa pela mudança nos processos de objetivação, portanto, pela transformação do trabalho, sem esquecer que se trata de um processo social total. (Gonçalves, 1992).

c) Processo de Trabalho

O processo de trabalho é compreendido por Marx como ação do homem sobre a natureza mediada por um certo saber acumulado. Nesse processo, o homem defronta-se com a natureza, e com sua ação transformaa em formas úteis à vida humana. Colocando em movimento as forças corporais e intelectuais, não apenas modifica a natureza como modifica a si mesmo. O que caracteriza o trabalho humano é também o fato de que ao 
final desse processo, o resultado já existia antes idealmente na imaginação de quem trabalha.

Os elementos que compõem o processo de trabalho são (Marx, s/d, p. 202):

i. a atividade adequada a um fim, isto é, o próprio trabalho;

ii. a matéria a que se aplica o trabalho, o objeto de trabalho;

iii. os meios de trabalho, o instrumental de trabalho.

Compõem os objetos de trabalho as matérias sobre a qual se aplica o trabalho, não apenas a matéria-prima, que são filtradas pelo trabalho anterior, modificadas pelo trabalho de outro, por exemplo, a extração de minérios, mas também o meio natural, a natureza em si, como a terra.

Os meios de trabalho relacionam-se ao conjunto de coisas que serve ao trabalhador para agir sobre o objeto de trabalho. "Ele utiliza as propriedades mecânicas, físicas, químicas das coisas, para fazê-las atuarem como forças sobre outras coisas, de acordo com o fim que tem em mira" (Marx, s/d, p. 203). São, por exemplo, as ferramentas, máquinas, tecnologias, que são utilizadas pelos trabalhadores, para transformar a matéria prima em objeto útil, em valor de uso (Aranha e Silva, 1997).

Meio e objeto de trabalho, por sua vez, compõem os meios de produção. Para os marxistas, são os meios de produção o que distingue as sociedades nas diferentes épocas, pois eles indicam o desenvolvimento da força humana de trabalho e as condições sociais em que o trabalho se realiza.

\subsection{Operacionalização de outros conceitos}

Nesta pesquisa utilizamos alguns conceitos essenciais à análise do material empírico, considerando os objetivos deste estudo: desinstitucionalização, reabilitação psicossocial, cooperativismo e cooperativa social. 
a) Desinstitucionalização como Emancipação

É consenso entre os autores da Reforma Psiquiátrica Brasileira que a noção de desinstitucionalização ${ }^{20}$ seja um conceito chave para nortear as políticas de assistência à saúde mental. Entretanto, este conceito assumiu significados diversos e algumas vezes opostos nas distintas experiências de psiquiatria reformada (Nicácio, 2003).

No campo da Reforma Psiquiátrica, o termo desinstitucionalização surgiu nos EUA para designar os processos de desospitalização, promovidos pelo Plano de Saúde Mental do Governo Kennedy. Essa noção nasceu dos projetos de psiquiatria preventiva e comunitária, que criticava o sistema psiquiátrico, mas validava $\circ$ paradigma psiquiátrico tradicional, pois apresentava medidas saneadoras e racionalizadoras, como diminuição de leitos e de permanência hospitalar, ao mesmo tempo em que criava uma rede de serviços comunitários, porém não pretendia uma real transformação da natureza da assistência (Amarante, 1996).

A noção de desinstitucionalização presente na Reforma Psiquiátrica Brasileira e utilizada na presente pesquisa, é herdeira da formulação italiana, que é entendida como abolição de todos os mecanismos de controle e violência que foram historicamente dirigidos à loucura. Trata-se da desmontagem de todos os aparatos científicos, legislativos, culturais, políticos, sociais que excluíram a loucura da vida em sociedade. Trata-se de desconstruir o objeto da doença mental, que foi simplificado pela psiquiatria, e reconstruir a complexidade e riqueza da existência-sofrimento, buscando construir/inventar soluções reais e concretas para as suas necessidades, cujo horizonte está relacionado à emancipação, à produção e reprodução da vida (material e subjetiva).

Em síntese, a desinstitucionalização como emancipação refere-se a:

...um processo, a um só tempo, de desconstrução de saberes e práticas - expresso, sobretudo nos princípios de colocar entre parênteses a doença mental, o que permite a identificação e a desmontagem do duplo da doença mental, e no trabalho com o sujeito concreto, encortinado pelo conceito de doença -, a de invenção prático-teórica de novas formas de lidar, não mais com a doença, mas com o sujeito doente (Amarante, 1996, p.95).

${ }^{20}$ A esse respeito ver também Amarante (1996) e Nicácio (1990). 
b) Reabilitação Psicossocial como Cidadania

O conceito de Reabilitação Psicossocial que orienta este estudo é definido como um processo que consiste "na reconstrução do exercício pleno de cidadania e, também, de plena contratualidade nos três grandes cenários: habitar, rede social e trabalho com valor social" (Saraceno, 2001, p.16).

Está vinculado à idéia de cidadania não como restituição de direitos formais, mas como construção real dos direitos materiais das pessoas com sofrimento psíquico de seus direitos substanciais. Esse processo de construção abrange vários elementos da vida humana: afetivo, relacional, material, habitacional e produtivo. (Saraceno, 2001). Trata-se também de um processo ético, porque é contrário ao estigma, à violência e à exclusão social.

Em linhas gerais, o autor italiano discute o conceito e a prática da reabilitação psicossocial, assumindo uma crítica aos modelos da Reabilitação Psiquiátrica em favor da reabilitação como construção da cidadania. Para ele, a reabilitação psicossocial no contexto da desinstitucionalização deve procurar resignificar a subjetividade do indivíduo na sua relação com a instituição, possibilitando a recuperação da contratualidade, ou seja, da posse de recursos para trocas sociais, para a cidadania social (Saraceno, 2001).

O trabalho na Reabilitação Psicossocial é entendido como inserção laborativa, não meramente um meio de sustento, mas um meio de autorealização, a partir da construção de um espaço de produção de sentidos e valores subjetivos de troca. Para tal, a cooperativa é compreendida uma forma organizacional inovadora no contexto da desinstitucionalização, capaz de subverter à lógica do trabalho institucional, explorador e dependente, se tornando uma forma concreta de solidariedade, pela presença de sócios "normais" e sócios "inabilitados". Possibilita ainda processos de responsabilidade e capacidade de escolha e risco que interessam a todos os participantes. Os lucros gerados pela cooperativa possibilitam oportunidades de empreendimento, de desenvolvimento de competências e da capacidade para os sócios (Saraceno, 2001). 


\section{c) Cooperativismo Social}

O movimento cooperativista nasceu inicialmente com os socialistas utópicos que propunham a autogestão do trabalho como reação defensiva ao desemprego e às condições de vida e de trabalho dos operários industriais no século XIX. O ano de 1844 representa um marco no cooperativismo devido à criação de uma cooperativa de consumo de operários têxteis, na cidade Rochdale, Inglaterra. Desde então, o movimento expandiu-se, conservando seus princípios de igualdade e democracia, conhecidos por princípios de Rochdale (Lima, 2004).

Os princípios atuais do cooperativismo foram definidos pela Aliança Cooperativa Internacional em 1995: associação voluntária e aberta; controle democrático pelos sócios; autonomia e independência; educação, formação e informação; colaboração entre cooperativas; preocupação com a comunidade (Mauad, 2001).

Entende-se por cooperativas:

Cooperativas são empresas constituídas por trabalhadores
(produtores ou consumidores) em prol dos diversos interesses
econômicos e sociais dos trabalhadores. Nisto são diferentes das
empresas capitalistas, que são constituídas com a finalidade de
gerar lucro, ou seja, de concentrar capital. São, portanto,
empreendimentos econômicos sem fins lucrativos, que visam à
satisfação das necessidades econômicas dos trabalhadores,
produtores ou consumidores, que são seus cooperados (UNISOL
Brasil, disponível em http://www.unisolbrasil.org.br, retirado em
29/11/2007).

$\mathrm{Na}$ perspectiva da Economia Solidária, a cooperativa social caracteriza-se por ser empreendimento cujo objetivo principal é a melhoria da vida das pessoas em dificuldades permanentes ou temporárias. As cooperativas sociais foram largamente difundidas nos países como a Itália e a França, entretanto no Brasil ainda não conseguiram atingir tal objetivo devido principalmente aos obstáculos legais.

A Lei $n^{\circ}$ 9.867, de 10 de novembro de 1999, define a cooperativa social como uma entidade constituída com a finalidade de inserir as pessoas em desvantagens no mercado econômico por meio do trabalho. Fundamentam-se no interesse geral da comunidade em promover a pessoa humana e a integração social dos cidadãos, e incluem entre suas atividades: a organização e gestão de serviços sociossanitários e educativos; e o 
desenvolvimento de atividades agrícolas, industriais, comerciais e de serviços. Na denominação e razão social das entidades é obrigatório o uso da expressão "Cooperativa Social", aplicando-se Ihes todas as normas relativas ao setor em que operarem, desde que compatíveis com os objetivos da Lei.

São consideradas pessoas em desvantagens: os deficientes físicos e sensoriais; os deficientes psíquicos e mentais, as pessoas dependentes de acompanhamento psiquiátrico permanente, e os egressos de hospitais psiquiátricos; os dependentes químicos; os egressos de prisões; os condenados a penas alternativas à detenção; os adolescentes em idade adequada ao trabalho e situação familiar difícil do ponto de vista econômico social ou afetivo (Dicionário Jurídico, disponível em http://www.direitonet.com.br, retirado em 29/11/2007).

Na parceria entre os movimentos da Economia Solidária e da Reforma Psiquiátrica, as cooperativas sociais e outros empreendimentos solidários se configuram como uma resposta à exclusão pelo mercado, daqueles que não coadunam do individualismo e da competição, que caracterizam a sociedade capitalista. Vistos como uma opção ética e política se constituem pela união de esforços contra a exclusão na construção de "empreendimentos produtivos, redes de troca, instituições financeiras, escolas, entidades representativas, que apontam para uma sociedade marcada pela solidariedade, da qual ninguém é excluído contra a vontade" (Singer, 2005, p. 15).

Nesse sentido, a criação de cooperativas sociais na saúde mental possibilita romper com a tradição terapêutica do trabalho, dirigindo-se à construção real de autonomia e de possibilidade social e subjetiva. $\mathrm{O}$ trabalho nas cooperativas sociais não apenas aponta para uma possibilidade real de oferta de trabalho às pessoas em desvantagem, que não conseguem se inserir no mercado, mas também para a construção de espaços de trocas subjetivas e sociais, de validação e reprodução social dos envolvidos (Amarante, 1997).

Neste estudo, a cooperativa social é entendida como uma estratégia de reabilitação psicossocial pelo trabalho no sentido da desinstitucionalização 
como emancipação para pessoas em desvantagem no contexto da parceria entre o movimento da Reforma Psiquiátrica Brasileira e da Economia Solidária. Além dos princípios que norteiam as cooperativas, buscamos nos aproximar do modelo de cooperativa social desenvolvido na experiência da Psiquiatria Democrática Italiana. Esse modelo de cooperativa possibilita a todos os sócios a participação ativa em todo o processo de tomada de decisão da empresa e favorece a participação, a qualidade do ambiente de trabalho, a qualidade do produto, o respeito às diferenças individuais (habilidades, potencialidades e limites).

Contudo, trata-se de um problema de equilíbrio difícil entre "a necessária solidariedade e igualdade de direitos, a indispensável autonomia econômica e a qualidade do ambiente de trabalho, das relações e do produto" (Strutti, 1997, p. 21). Somada a este desafio, a cooperativa social também se propõe a transformar as imagens e representações que a sociedade possui acerca do doente mental, do doente, do marginalizado, do pobre, das pessoas em situação de vulnerabilidade.

A cooperativa social como possibilidade de trabalho aos usuários de saúde mental, portanto, deve objetivar "a produção da emancipação e de autonomia, de ampliação da contratualidade social, ou do que tem sido denominado atualmente de empoderamento" (Nicácio, 2005, p. 78).

\section{Percurso Exploratório}

\subsection{Cenário da Pesquisa}

O cenário da pesquisa é o Núcleo de Oficinas e Trabalho (NOT), que está sob a responsabilidade do Serviço de Saúde Cândido Ferreira, localizado no município de Campinas, e que possui atualmente doze oficinas de trabalho.

O município de Campinas tem uma história de 260 anos que remonta aos tempos do Brasil colônia e de milhares de anos de história indígena. A cidade surgiu na primeira metade do século XVIII como um bairro rural da Vila de Jundiaí, que estava localizado nas margens de uma trilha aberta por paulistas em direção às minas dos Goiases. O povoamento do "Bairro Rural do Mato Grosso" teve início com a instalação de um pouso de tropeiros, o 
pouso das "Campinas do Mato Grosso". Com a chegada de fazendeiros, no mesmo período, e a instalação de lavouras de cana e engenhos de açúcar, o bairro rural do Mato Grosso foi transformado em Freguesia de Nossa Senhora da Conceição de Campinas do Mato Grosso (1774); depois em Vila de São Carlos (1797) e em Cidade de Campinas (1842); quando as plantações de café já suplantavam as culturas de cana (Prefeitura Municipal de Campinas, disponível em http://www.campinas.sp.gov.br, retirado em 09/09/2007).

A partir da economia cafeeira, Campinas passou a concentrar um grande contingente de trabalhadores escravos e livres de diferentes procedências. Tal fato impulsionou o desenvolvimento de meios de transporte, de produção e de vida. A partir da década de 1930, com a crise da economia cafeeira, a cidade assumiu uma característica mais industrial e de serviços. A partir da instalação de um novo parque produtivo, entre as décadas de 1930 e 1940, Campinas passou a receber migrantes e imigrantes das mais diversas regiões do Brasil e do mundo, o que representou a ampliação dos bairros nas proximidades das fábricas, dos estabelecimentos e das grandes rodovias (Prefeitura Municipal de Campinas, disponível em http://www.campinas.sp.gov.br, retirado em 09/09/2007).

Desde então, a cidade de Campinas aumentou seu território em 15 vezes e sua população em cerca de 5 vezes. Atualmente, Campinas ocupa uma área de $801 \mathrm{Km}^{2}$ e tem uma população aproximada de 1 milhão de habitantes distribuída por quatro distritos: Joaquim Egídio, Sousas, Barão Geraldo e Nova Aparecida. Campinas forma com mais 19 cidades, a região metropolitana de São Paulo, que conta com uma população estimada de 2,33 milhões de habitantes (Prefeitura Municipal de Campinas, disponível em http://www.campinas.sp.gov.br, retirado em 09/09/2007).

O Serviço de Saúde Dr. Cândido Ferreira está localizado no distrito de Sousas a $93 \mathrm{~km}$ da capital e é referência no tratamento em saúde mental no Brasil desde 1993, pela Organização Mundial de Saúde (OMS). Atualmente atende mais de mil usuários por mês, e conta com um Núcleo de Atenção à Crise, um Núcleo de Atenção a Dependentes Químicos, três Centros de Atenção Psicossocial (CAPS Estação, CAPS Toninho e CAPS Esperança), um Núcleo Clínico, um Núcleo de Oficinas e Trabalho (NOT), um Centro de 
Convivências e Arte e o Centro Cultural Cândido-Fumec. Os principais objetivos do Cândido Ferreira são a desospitalização, a participação social dos usuários e o respeito ao direito à convivência dos diferentes (Serviço de Saúde Dr. Cândido Ferreira, disponível em http://www.candido.org.br, retirado em 09/09/2007).

O Sanatório Cândido Ferreira foi inaugurado em 14 de Abril de 1924, e foi a segunda instituição psiquiátrica do estado de São Paulo. Sua fundação foi motivada por uma matéria do jornal $O$ Estado de São Paulo, publicada em 1916, que denunciava os maus tratos cometidos contra os portadores de sofrimento psíquico, que ficavam presos no porão da cadeia pública de Campinas. Em 1990, após a assinatura do convênio de co-gestão com a Prefeitura Municipal de Campinas, houve uma reformulação da assistência no hospital e "os tratamentos passaram a se dar buscando a reinserção social dos usuários na vida familiar e comunitária" (Serviço de Saúde Dr. Cândido Ferreira, disponível em http://www.candido.org.br, retirado em 09/09/2007).

O Núcleo de Oficinas e Trabalho (NOT) foi criado em 1991 no contexto da reformulação da assistência à saúde mental ocorrida no município de Campinas. O programa de saúde mental do município que pretendia reforçar uma rede básica em substituição ao hospício, viu-se na incumbência de assumir a responsabilidade pelo Sanatório filantrópico Dr. Cândido Ferreira, a partir da assinatura do convênio de co-gestão, motivada pela grave crise financeira e pelo objetivo de resgatar o caráter público deste serviço filantrópico, aumentando a oferta e exercendo maior controle público sobre a demanda de internações (Onocko, Amaral, 2002). Na ocasião, tratava-se de uma instituição de caráter manicomial, fundada em 1924, que contava com 131 pacientes internos e precários recursos financeiros, materiais e humanos, oferecendo uma assistência baseada no modelo hospitalocêntrico de características asilares e excludentes (Campos, 2000).

No período anterior, compreendido entre o final da década de 70 até o inicio da década de 90 , intensas mobilizações sociais e políticas pela redemocratização do país após 20 anos de ditadura militar, entre elas, o movimento da reforma sanitária, culminaram na Constituição de 1988 e na criação do SUS em 1989, tornando possível a reestruturação da assistência 
à saúde no país em direção a organização de um sistema de saúde baseado na universalização, na equidade, na integralidade, na regionalização e na participação popular, considerados princípios fundamentais para o setor da saúde pública.

No campo do movimento pela reforma psiquiátrica, os crescentes debates e denúncias sobre a privatização e mercantilização da loucura e a influência dos processos de reformas em outros países, especialmente na Itália, foram cada vez mais se dirigindo à necessidade de ruptura com o paradigma psiquiátrico para transformar a assistência à saúde mental não apenas em termos técnico-assistenciais, mas também político-jurídico, teórico-conceitual e sociocultural. A desinstitucionalização como desconstrução/invenção tornou-se um dos horizontes estratégicos desse processo de mudanças que visava "transcender os modelos preestabelecidos pela instituição médica, movendo-se em direção às pessoas, às comunidades" (Amarante, 1995, p.94). Cabe ressaltar que esse processo de debates e reformulações não se deu sem resistências daqueles que defendiam o modelo tradicional, com avanços e retrocessos, culminando em diversas experiências municipais que conservam características particulares.

O processo de transformação da assistência à saúde mental em Campinas também fez parte desse acúmulo de debates e reformulações, envolvendo diversos protagonistas que enfrentaram alguns desafios como 0 de desinstitucionalizar os pacientes do Serviço de Saúde Dr. Cândido Ferreira:

Um grande desafio, que pelo menos se traduziu, inicialmente, em desospitalizar: rever diagnósticos, recuperar histórias, localizar famílias, reabilitar com o atelier e oficinas de trabalho - e reinserir na vida social (Campos, 2000, p. 107).

O processo de reforma campineira se caracterizou pela hibridez, uma vez que havia dois modelos em luta. O primeiro modelo tinha a rede básica como porta de entrada e organizava-se pela hierarquização dos serviços, influenciado pelos princípios da reforma sanitária, entretanto resistia à idéia de "fazer algo muito diferente do conhecido, e não se conseguia ir além de melhorar o modelo instituído" (Campos, 2000, p. 109), defendida pelo outro 
modelo. Os dispositivos CAPS, por exemplo, eram e são considerados "equipamentos intermediários", de referência secundária, sem porta aberta e sem hospitalidade noturna. Privilegiava-se o investimento nas equipes da rede básica de saúde, gerando polêmicas e confusões com relação ao modelo de assistência à saúde mental a ser implantado no município. Como resultado a área de saúde mental em Campinas, segundo a autora, sofreu uma dicotomia que persiste até hoje: a rede de Centros de Saúde e o Serviço de Saúde Dr. Cândido Ferreira.

O modelo de atenção à saúde mental em Campinas, portanto, caracteriza-se pela forte influência da reforma sanitária ocorrida no município, onde atenção à saúde foi organizada de forma distrital em torno de 50 centros de saúde e serviços secundários distribuídos pelos 5 distritos sanitários:

A complexidade do sistema de saúde em Campinas levou à
distritalização, que é o processo progressivo de descentralização do
planejamento e gestão da saúde para áreas com cerca de 200.000
habitantes, que em nosso município iniciou-se com a atenção
básica, sendo seguido pelos serviços secundários próprios e
posteriormente pelos serviços conveniados / contratados. Esse
processo exigiu envolvimento e qualificação progressivos das
equipes distritais e representou grande passo na consolidação da
gestão plena do sistema no Município. (Secretaria Municipal de
Saúde, disponível em http://antigo.campinas.sp.gov.br/saúde/
retirado em 29/01/09).

Ao longo desses anos, a rede de saúde mental em Campinas expandiu-se consideravelmente em relação a outros municípios do país e atualmente conta com atendimento na rede básica de saúde que são a porta de entrada do sistema e com serviços especializados próprios e conveniados com o SSCF, como os Centros de Atenção Psicossocial (CAPS), considerados como unidades de referência secundária (intermediárias) de saúde mental, compostos por equipe multiprofissional, cuja missão é de:

...tratar de forma intensiva os portadores de transtorno mental grave ou em uso de substâncias psicoativas, na sua comunidade, junto às suas famílias, evitando a internação psiquiátrica integral e promovendo a reabilitação psicossocial dos cronicamente comprometidos". (Secretaria Municipal de Saúde, disponível em http://antigo.campinas.sp.gov.br/saúde/ retirado em 29/01/09). 
Atualmente a rede de saúde mental em Campinas conta com 36 residências terapêuticas e 9 CAPS, sendo que 5 destes funcionam 24 horas, número considerado adequado para a construção de uma rede efetivamente substitutiva à internação em instituições totais. O SSCF por meio da cogestão com o município também faz parte dessa rede de saúde mental e atualmente atende um público de mais de mil usuários por mês, tendo sob sua responsabilidade um Núcleo de Atenção à Crise, um Núcleo de Atenção à Dependência Química, quatro Centros de Atenção Psicossocial (CAPS), um Núcleo Clínico, 13 Oficinas de Trabalho do NOT, três Centros de Convivência (Espaço das Vilas, Centro Cultural Cândido-Fumec e Casa Escola "Rosa dos Ventos"), o Cândido Escola, unidade voltada à formação em trabalho e consultoria e 2 oficinas de Comunicação Comunitária: de jornal impresso (C@ndura - Espaço Aberto para um Novo Pensamento) e de rádio (Ponto de Cultura Rádio Comunitária "Maluco Beleza"). (Serviço de Saúde Dr. Cândido Ferreira, disponível em http://www.candido..org.br, retirado em 29/01/09).

Com o objetivo inicial de transformar tanto a assistência em direção à desinstitucionalização e à reabilitação psicossocial bem como a forma de gestão para uma gestão mais democrática e pautada pela auto-gestão, o processo de transformação do modelo assistencial ocorrido no SSCF resultou na criação de inúmeros dispositivos e serviços cuja atenção fundamenta-se na singularidade do usuário e na conquista da cidadania, a partir da inserção na comunidade (Campos, 2000). Estes serviços foram estruturados em 4 unidades de produção assistenciais: Hospital-dia, Unidade de Internação de pacientes em crise, Núcleo de Oficinas e Trabalho e Unidade de Reabilitação de pacientes moradores.

Desde 1990, através de uma parceria entre a Prefeitura Municipal de Campinas e o Cândido Ferreira as formas de cuidar em saúde mental foram humanizadas. Por esta nova postura, desde 1993, a instituição é considerada referência de tratamento no país, pela Organização Mundial de Saúde (OMS). A principal meta da instituição é a desospitalização. (Serviço de Saúde Dr. Cândido Ferreira, disponível em http://www.candido.org.br, retirado em 29/01/09). 
Com relação às transformações do modelo de gestão, o SSCF participou de uma experiência de pesquisa aplicada realizada pelo LAPA ${ }^{21}$ que entre outras mudanças propôs um sistema de direção colegiada para horizontalizar a relação de poder entre a gerencia (em substituição as clássicas funções de diretor administrativo, técnico e de enfermagem) e as unidades de produção, facilitando não apenas a comunicação mais direta com a exclusão dos níveis intermediários mas também possibilitando maior autonomia e agilidade nas decisões (Onocko, Amaral, 2002).

A partir de 1993, o SSCF apresenta dificuldades econômicas que colocaram em risco sua existência devido a retração no financiamento por parte da Secretaria Municipal de Saúde e a baixa participação financeira da Secretaria do Estado de Saúde. Entretanto, o fato de ser uma entidade filantrópica com autonomia político-administrativa possibilitou a continuidade do projeto, mesmo numa conjuntura difícil. Logo, "entre todos os contratempos do contexto, o Cândido resistiu com o recurso do seu texto, mantendo os desafios evidenciados no horizonte, teimando em tornar possível o improvável" (Onocko, Amaral, 2002, p.363).

A rede de saúde mental implantada em Campinas, de 2001 a 2004, apontou alguns aspectos importantes para a construção do modelo de atenção psicossocial, de fato, substitutivo ao modelo psiquiátrico tradicional. Tal fato, portanto, justifica a escolha do município de Campinas, referência de modelo na história da reforma psiquiátrica brasileira, particularmente o Núcleo de Oficinas e Trabalho, que atualmente conta com 12 oficinas de trabalho e funciona segundo o modelo cooperado, como cenário deste estudo.

O Núcleo de Oficinas e Trabalho do Serviço de Saúde Dr. Cândido Ferreira foi criado desde $1991 \mathrm{com}$ a primeira oficina que atendia a demanda de dez usuários. O NOT atualmente conta com a participação de 250 usuários distribuídos em 12 oficinas, cuja finalidade é atender a necessidade de trabalho da população de baixa renda com transtorno mental e sem

\footnotetext{
${ }^{21}$ Laboratório de Administração e Planejamento do Departamento de Medicina Preventiva e Social da Faculdade de Ciências Médicas da UNICAMP que realizou uma pesquisa aplicada no Serviço de Saúde Dr. Cândido Ferreira sobre planejamento estratégico publicada sob o título Cândido Ferreira: experimentando uma mudança institucional (Onocko, Amaral, 2002).
} 
oportunidades de inserção no mercado informal, excluídas, portanto, das oportunidades de convívio social e exercício da cidadania. Os usuários recebem uma bolsa-oficina, de acordo com a produção mensal. Alguns deles têm a possibilidade de retornar à atividade formal. Os produtos desenvolvidos pelos usuários são comercializados através da Internet, da loja Armazém das Oficinas, inaugurada em outubro de 2003 e localizada no centro de Campinas, e em algumas grandes feiras de decoração de São Paulo, como a Gift Fair e Home Brasil (Serviço de Saúde Dr. Cândido Ferreira, disponível em http://www.candido.org.br, retirado em 09/09/2007).

Além da habilitação para o trabalho, O NOT propicia a convivência, a ampliação da rede social, a formação profissional e a geração de renda aos participantes, proporcionando assim a inclusão social pela atividade. O acompanhamento dos usuários é realizado por profissionais da área da saúde mental, que estimulam o desenvolvimento das potencialidades e habilidades individuais, a interação grupal e os princípios cooperativos democráticos (Serviço de Saúde Dr. Cândido Ferreira, disponível em http://www.candido.org.br, retirado em 09/09/2007).

Atualmente o Núcleo de Oficinas e Trabalho conta com 12 oficinas terapêuticas de capacitação: Oficina de Culinária, Oficina de Papel Reciclado, Oficina Gráfica, Oficina de Velas, Oficina de Vitral Plano, Oficina de Construção, Oficina de Vitrais, Oficina Agrícola, Oficina de Mosaico, Oficina de Marcenaria, Oficina de Serralheria e o Projeto Parceira (Serviço de Saúde Dr. Cândido Ferreira, disponível em http://www.candido.org.br, retirado em 09/09/2007).

A seguir, apresentamos uma brevíssima descrição das oficinas do Núcleo de Projetos Especiais ${ }^{22}$ :

1) Oficina de Papel: iniciou suas atividades em 1993, e atualmente oferece 15 vagas para usuários. Objetiva a produção artesanal de papel que será utilizado em agendas, cadernos, bloco de anotações, entre outros produtos. Localiza-se na unidade de Sousas.

2) Oficina Gráfica: foi fundada em 1993, oferecendo 18 vagas, destina-se à confecção de produtos gráficos (agendas, cadernos, etc) produzidos em papel reciclado. Unidade Cambuí.

\footnotetext{
${ }^{22}$ A esse respeito, acessar o portal da instituição disponível em http://www.candido.org.br/ e também Guanais (2000)
} 
3)Oficina de Vitrais: teve início em 1997, e hoje oferece 22 vagas. Realiza trabalhos artesanais, desenvolvendo peças de decoração, como luminárias, abajures e porta-velas. Unidade Sousas.

4) Oficina de Vitral Plano: fundada em 2002, oferece 10 vagas a usuários na Criação de vitrais planos coloridos e cheios de criatividade. Funciona na unidade Cambuí.

5) Culinária: fundada em 1992, hoje oferece vagas a 20 usuários, que produzem salgados, bolos e doces, sob encomenda, além de completo serviço de buffet. Atualmente atendem também no Café da loja Armazém das Oficinas, no Cambuí.

6) Agrícola: teve início em 1992, e hoje atende 45 usuários. A oficina produz verduras e hortaliças sem agrotóxicos, além de prestar serviços de jardinagem e manutenção de chácaras. Está em implementação uma estufa de produtos fitoterápicos.

7) Marcenaria: fundada em 1998, atualmente atende 15 usuários. Nesta oficina aprende-se o ofício de marceneiro através de produção de peças como abajures de madeira, porta-CDS, armários, e brinquedos educativos.

8) Mosaico: teve início em 1999, e hoje atende 15 usuários. A doação de azulejos e pisos é transformada em peças de mosaico como mesas, armários, floreiras, porta-revista, descanso de panelas, entre outras.

9) Serralheria: fundada em 2000, atende 15 usuários. Mesa, porta-vela, cama, escada, etc., são criados nesta oficina, em que os usuários aprendem o ofício de serralheiro.

10) Velas: fundada em 2001 , oferece 8 vagas a usuários, que criam velas artesanais aromatizadas das mais diversas formas. Atualmente esta oficina funciona no Cambuí.

11) Construção e Ladrilho: 16 vagas e 5 vagas respectivamente.

12) Projeto Parceria: teve início em 1999, e hoje conta com a participação de 22 usuários, que se engajam em serviços institucionais como limpeza, rouparia, lavanderia, aprendendo os ofícios e desenvolvendo seus tratamentos.

Loja Armazém das Oficinas: loja que vende os produtos produzidos nas oficinas do Cândido Ferreira. 


\subsection{Fonte de Dados Empíricos}

Para atingir os objetivos propostos nesta pesquisa, foram realizadas entrevistas com a gerente do serviço e com doze coordenadores das oficinas de trabalho do Núcleo de Oficinas e Trabalho. Na ocasião das entrevistas, a gerente também exercia a função de coordenadora de oficina, sendo incluída, portanto, entre os sujeitos da pesquisa.

Todos estes sujeitos possuem grau de escolaridade superior, sendo que quatro são terapeutas ocupacionais, três assistentes sociais, duas nutricionistas, uma psicóloga e a outra enfermeira.

A escolha da totalidade de coordenadores como sujeitos da pesquisa se justificou pelo fato destes serem trabalhadores em saúde que participam de um processo de reformulação assistencial no campo da saúde mental desenvolvendo intervenções de natureza reabilitadora por meio do trabalho. Devido à sua formação profissional e à função de coordenação das oficinas de trabalho foram considerados pela presente pesquisa sujeitos capazes de definir o trabalho que realizam, qualificando a proposta de suas intervenções, e identificando as possibilidades e limites dessa experiência particular. A partir de seus discursos, foi possível apreender as concepções de reabilitação psicossocial, trabalho e cooperativismo social que orientam a organização do processo de trabalho, e que revelam o sentido do trabalho na proposta do Núcleo de Oficinas e Trabalho.

Os sujeitos desta pesquisa se caracterizam em sua totalidade por serem pessoas do sexo feminino, com idades que variam entre 25 e 58 anos, e possuem formações profissionais na área da saúde, à exceção de duas nutricionistas. Além da graduação, os sujeitos apresentam capacitações como cursos de atualização (6 entrevistados) e de especialização (8 entrevistados). Apresentam trajetórias profissionais distintas, sendo que 0 tempo de atuação no serviço variou entre 11 meses e 11 anos e 8 meses.

\subsection{Procedimentos para Coleta e Análise dos Dados}

Antes da realização das entrevistas, o projeto de pesquisa foi submetido ao Comitê de Ética e Pesquisa da Escola de Enfermagem da Universidade de São Paulo (CEP-EEUSP), conforme a Resolução $n^{\circ} 196$, de 
10/10/1996, que dispõe sobre as normas de pesquisa envolvendo seres humanos. O projeto obteve aprovação por meio do processo $n^{\circ}$ 721/2008/CEP-EEUSP (anexo 1).

Em seguida, o projeto foi enviado ao Comitê de Ética Médica do Serviço de Saúde Dr. Cândido Ferreira, sendo aprovado conforme parecer $\mathrm{n}^{\circ}$ 10/2008 (anexo 2). Também foi encaminhada solicitação de autorização à coordenadora do Cândido Escola e à gerente do NOT para este serviço configurar-se como cenário da pesquisa (anexo 3), obtendo resposta favorável (anexo 4).

Após apresentação e esclarecimento da finalidade da pesquisa para a gerente do serviço, procedeu-se à realização das entrevistas, primeiramente com a gerente e depois com os coordenadores das oficinas.

A coleta de dados foi realizada durante os meses de Junho e Julho de 2008, por meio de entrevistas semi-estruturadas, baseadas num roteiro prédefinido. A duração das entrevistas variou de 45 a 80 minutos.

As entrevistas foram agendadas pela gerente, conforme a disponibilidade dos sujeitos e da pesquisadora, garantindo também a continuidade da rotina institucional. No início de cada entrevista foram realizados os procedimentos ético-legais: assinatura do Termo de Consentimento Livre e Esclarecido (apêndice 1), autorização do uso de gravador e garantia em não participar da pesquisa a qualquer momento.

A interação humana numa entrevista não é simplesmente um trabalho de coleta de dados, mas uma relação na qual as informações oferecidas pelo sujeito podem ser profundamente afetadas pela natureza desse encontro (Minayo, 2006). Levando em conta essa preocupação, buscamos não interferir nos depoimentos respondendo apenas às questões feitas pelos entrevistados, procurando reduzir os vieses na captação da realidade.

A entrevista com a gerente do serviço teve como objetivo a coleta de dados acerca da estruturação e funcionamento do NOT bem como sobre a organização do processo de trabalho do serviço (apêndice 2). Posteriormente, realizamos uma nova entrevista sobre o trabalho específico na oficina em que ela também exercia, na ocasião, a função de coordenadora. 
Na primeira parte da entrevista com os coordenadores (apêndice 3) foram solicitadas algumas informações importantes à caracterização dos sujeitos como: data de nascimento, sexo, naturalidade, estado civil, função, grau de escolarização, tempo de trabalho no NOT, experiências anteriores.

$\mathrm{Na}$ segunda parte foi solicitado aos entrevistados que descrevessem uma situação que expressasse a proposta da oficina. Em seguida, foi pedido que comentassem sobre o processo de inserção e de permanência do usuário na oficina. Logo, solicitamos sua opinião sobre os limites/dificuldades e possibilidades das oficinas de trabalho e finalmente sua avaliação das oficinas de trabalho na transformação da vida dos oficineiros.

Após a realização das entrevistas, o material coletado na forma de gravação em fitas foi transcrito integralmente para viabilizar a análise dos depoimentos. Para a coleta de dados também foram utilizadas outras fontes de informação complementar como consultas aos artigos e documentos oficiais obtidos pelo acesso aos sites do Serviço de Saúde Cândido Ferreira, da loja Armazém das Oficinas e da prefeitura do município de Campinas, bem como consultas aos artigos publicados em livros científicos.

Para análise e tratamento dos dados foi utilizado como método a análise de conteúdo, na modalidade conhecida por Análise Temática. A escolha por esse método de análise dos dados se justifica pela consideração do contexto social e histórico sob o qual foram produzidos os conteúdos, o que vai de encontro com a relação dialética aparência/essência.

A análise de conteúdo pode ser definida como:

Um conjunto de técnicas de análise de comunicação visando obter, por procedimentos sistemáticos e objetivos de descrição dos conteúdos das mensagens, indicadores (quantitativos ou não) que permitam a inferência de conhecimentos relativos às condições de produção/recepção dessas mensagens (Bardin, 1979 apud Minayo, 2006, p.303).

Sendo um método muito utilizado na análise de dados qualitativos, a análise de conteúdo é um conjunto de técnicas de pesquisa cujo objetivo está vinculado à busca do sentido ou dos sentidos de um documento (Campos, 2004). Do ponto de vista operacional, parte de uma leitura de primeiro plano das falas, depoimentos e documentos, para chegar a um nível mais profundo, ultrapassando os sentidos manifestos do material. Dentre as várias 
modalidades, a Análise Temática é considerada a mais simples e mais apropriada para as investigações qualitativas em saúde (Minayo, 2006).

Em síntese, a técnica de análise temática "consiste em descobrir os 'núcleos de sentido' que compõem a comunicação e cuja presença, ou freqüência de aparição, podem significar alguma coisa para o objetivo analítico escolhido" (Bardin, 1979 apud Campos, 2004). Utilizando essa técnica, podemos caminhar na direção da descoberta do que está por trás dos conteúdos manifestos, para além das aparências do que está sendo analisado.

Portanto, fazer uma análise temática significa descobrir os núcleos de sentido, partindo da análise de significados. A presença de determinados temas denota estruturas de relevância, valores de referência e modelos de comportamento presentes ou subjacentes no discurso. A análise temática desdobra-se em três etapas: pré-análise, exploração do material e tratamento dos resultados obtidos e interpretação (Minayo, 2006).

$\mathrm{Na}$ primeira etapa, pré-analise, a primeira tarefa consistiu na leitura flutuante do material (após a transcrição de todas as entrevistadas gravadas) que se caracterizou pela releitura freqüente de cada entrevista, o que possibilitou a apreensão progressiva das idéias centrais contidas nos discursos sobre o tema investigado (Minayo, 2006).

A segunda tarefa consistiu na constituição do corpus, ou seja, na totalidade do universo estudado, buscando responder algumas normas de validade qualitativa: exaustividade, representatividade, homogeneidade, pertinência; no sentido de verificar se o material analisado era adequado para responder aos objetivos do estudo (Minayo, 2006).

A partir de então, procedeu-se à retomada da etapa exploratória a partir da leitura exaustiva do material com base nas indagações iniciais, determinando também as palavras-chaves ou frases, os recortes, a forma de categorização e alguns conceitos teóricos, que surgiram e foram incorporados nesta fase considerando a totalidade e a riqueza dos dados.

A segunda etapa consistiu na organização do material, a partir da operação classificatória, buscando o núcleo de compreensão do texto. Logo, procedeu-se a classificação das frases em temas centrais conforme suas 
semelhanças. Tratou-se de realizar a categorização pela redução do texto às expressões significativas, aos temas centrais.

Após a captação dos temas centrais, que foram expressos em frases, procedeu-se ao agrupamento das frases temáticas de todos os depoimentos, segundo sua similaridade, dando origem às categorias empíricas, cuja finalidade operacional relaciona-se à apreensão das determinações e especificidades expressos pelos discursos sobre a realidade empírica. A partir de então, os resultados obtidos podem passar para a fase de tratamento e interpretação, sendo inter-relacionados com o quadro teórico inicial e com os conceitos surgidos nesse momento (Minayo, 2006).

Sendo assim, identificamos as seguintes categorias empíricas:

1. Projeto Institucional

2. Modo de Estruturação do serviço

3. Processo de Trabalho em Saúde

4. Concepções sobre Reabilitação Psicossocial, Trabalho e Cooperativismo Social.

Essas categorias e seus respectivos temas são apresentados a seguir na análise dos resultados da pesquisa. 
ANÁLISE DOS RESULTADOS 


\section{ANÁLISE DOS RESULTADOS}

...obedecer cegamente deixa cego, crescemos somente na ousadia só quando transgrido alguma ordem, o futuro se torna respirável todo mandato é minucioso e cruel, eu gosto das frugais transgressões.

Transgressões, Mario Benedetti

Buscando desvelar a essência do trabalho na experiência das oficinas do Núcleo de Oficinas e Trabalho, conforme exposto na metodologia deste estudo, partimos da análise dos depoimentos acerca da realidade, relatados pelos coordenadores, sujeitos desta pesquisa, e também pela gerente do serviço. $\mathrm{Na}$ análise dos dados, encontramos algumas informações essenciais à identificação das concepções utilizadas no processo de trabalho do serviço, que inicialmente reunimos sob o titulo Projeto Institucional do NOT. Também identificamos a importância do modo de estruturação desse serviço de saúde principalmente no que diz respeito ao acesso, adesão e desligamento (saída), que, por sua vez, se refletem no processo de trabalho em saúde, cujos elementos analisados apresentaram diferentes significações, algumas contraditórias entre si, corroborando com a abordagem dialética, na qual os fenômenos são compreendidos em movimento, e não de maneira estática e pura, sendo constituídos pela união e luta dos contrários.

Sendo assim, iniciamos a análise dos resultados com a discussão do projeto institucional do NOT, que originado no contexto da reformulação da saúde mental, buscou articular-se com o processo de Reforma Psiquiátrica Brasileira, modificando-se ao longo do tempo. A missão institucional, por sua vez, define o modo de organização de estruturação do serviço nas etapas principais do processo de trabalho do serviço. Por se tratar de um serviço de saúde, com características peculiares e objetivos específicos que se dirigem à reabilitação psicossocial, analisaremos alguns elementos que constituem o processo de trabalho em saúde, e o processo de trabalho nas oficinas, para compreender o sentido do trabalho, e assim identificar a concepção de trabalho, de reabilitação psicossocial e do cooperativismo social. 


\section{NOT: PROJETO INSTITUCIONAL E REFORMA PSIQUIÁTRICA}

Como vimos, o serviço NOT foi criado no contexto de transformação da assistência à saúde mental do município de Campinas e do SSCF influenciados pelo processo da Reforma Psiquiátrica Brasileira, a princípio buscando responder às necessidades de reabilitação de 20 moradores da instituição. Esse histórico foi revisitado pelos depoimentos tanto para esclarecer o projeto inicial quanto para explicitar o funcionamento e estrutura física atual do serviço, como se pode verificar a seguir:

E8.14 - o NOT iniciou em 91, 91 / 92. É que foi uma construção, do NOT. Iniciou junto com o movimento da reforma psiquiátrica aqui em Campinas, no Cândido, então quando foi criado o hospital-dia em 91, as oficinas logo em seguida vieram também, pra dar conta dessa população mais que estava internada dentro do Cândido.

Inicialmente, a equipe do NOT realizou um levantamento das atividades desenvolvidas pelos usuários nos diversos setores da instituição como lavanderia, rouparia, serviço de nutrição e agropecuária, constatando o papel do trabalho dos usuários: apoio aos funcionários e substituição de mão-de-obra para a manutenção da instituição. Em troca da realização desses trabalhos, os pacientes recebiam um prêmio que consistia na distribuição de doces, cigarros e objetos de higiene pessoal, comprados com o fundo de caixa do setor de Terapia Ocupacional, que, por sua vez, era fruto da venda de objetos produzidos nas atividades de marcenaria, de pintura e de montagem de prendedores desenvolvidos por esse setor. (Cayres et al., 2001).

A implantação do NOT, portanto, resultou da necessidade de redirecionar o trabalho objetivando uma nova dinâmica com vistas à criação de espaços de formação profissional que possibilitassem a instrumentalização e preparação dos usuários para sua reintegração na sociedade. A princípio foram propostas algumas frentes de trabalho nas Oficinas Agrícola, de Artesanato (fios e pintura) e de Culinária destinadas aos 20 usuários moradores da instituição, levando-se em conta a história ocupacional dos usuários, o espaço físico, os recursos materiais e humanos disponíveis e as atividades desenvolvidas na instituição (Guanais, 2000). Essa implantação aparece em alguns fragmentos de discursos dos coordenadores, como se vê no texto abaixo: 
E1.3 - a gente começa ocupando espaços a principio, espaço da TO e a oficina agrícola começa com a horta num terreno cedido pela comunidade por uma pessoa que tinha um terreno vazio e falou: Ah, se quiser plantar, pode plantar. Do sucesso disso, isso começou a dar certo, o pessoal plantou, a própria administração do hospital propôs passar pro pessoal cuidar da horta que tinha aqui; então quem era funcionário virou monitor e isso permitiu a questão da horta. Depois, jardim também tinha um funcionário que cuidava do jardim; aí ele aposentou, aí começa o jardim a partir de uma experiência que estava dando certo do pessoal ir fazer jardim na casa das pessoas e aí com o aval da instituição hoje os jardins do Cândido todo são cuidados pela Oficina Agrícola e Jardim. E os outros foram surgindo depois: a Oficina de Artesanato era só uma, aí foi virando Mosaico, de Papel Reciclado, Gráfica, Vitral... foi desmembrando e expandindo aí ...

Pouco tempo depois, o NOT passou a atender usuários de outros serviços da rede municipal e municípios vizinhos, ampliando o número de atendimentos e a oferta de espaços de trabalho. Esse crescimento demandou a criação, em 1993, por iniciativa dos profissionais, da Associação Cornélia Maria Elizabeth Van Hylckama Vlieg, comumente chamada Associação Cornélia, cujo propósito era oferecer respaldo técnico, jurídico, financeiro, organizacional e político às oficinas de trabalho.

O desenvolvimento do projeto e a conseqüente necessidade de fundação de outra organização que permitisse e facilitasse a obtenção de recursos financeiros e materiais, impedidos ou dificultados pelas normas dos serviços assistenciais públicos, que não permitem a compra de materiais sem processos licitatórios, em geral, demorados e limitados, bem como a venda de produtos, foram relatados pelos entrevistados na abordagem da composição do serviço:

E1.17 - quando começa o projeto, aí as oficinas começam a ter uma produção e a ter um recurso financeiro. Aí começou o primeiro problema - não tinha associação ainda -: o que fazer com aquele recurso, como dividir? Aí, foi a nossa primeira dificuldade pensar: e aí, queremos o que? Como que vai ser? Não dava pra usar a conta do Cândido, aí foi quando se pensou em montar a cooperativa, na época não foi possível, aí montou a associação, que virou a Associação Cornélia...

E1.18 - Daí, eram ex-moradores do hospital, tinham uma relação com uma terapeuta ocupacional que tinha aqui idosa, holandesa, e ela chamava, chama ainda, ela é viva, Cornélia Maria. Aí o pessoal: Ah, vamos pôr o nome dela! O hospital passava por dificuldade, ela sempre colaborava, trazia ajuda de fora, enfim... Aí colocou o nome dela. A associação foi sempre acompanhando o projeto dando essa coisa do respaldo jurídico. Então os contratos são feitos pela Associação, as compras de material. Com relação ao material da oficina é tudo comprado pela associação, via própria oficina. 
E8.2 - Então a associação é que faz as compras, as vendas, emite nota fiscal, cuida dessa parte jurídica.

A Associação Cornélia tem sede no espaço do SSCF com o qual estabeleceu um sistema de comodato e sua diretoria está formada por profissionais, usuários e familiares, eleitos para uma gestão de 2 anos. Trata-se, portanto, de uma organização sem fins lucrativos de representação democrática, conforme frases abaixo:

E8.4 (associação) - E aí tem essa diretoria que tem o tesoureiro, tem o presidente, tem o secretário, tem a gestão de dois anos, e aí é trocado, tem votação, eleição, tem representante de usuários também, de familiares, nessa diretoria.

E8.6 (associação)- E hoje os próprios, quem faz parte da diretoria é quem está na gestão das oficinas, são os coordenadores, a X que é gerente, tem a presidente que é uma pessoa de fora da entidade, e que está muito presente, compartilha os mesmo ideais.

E8.5 (associação) - Ela funciona na mesma sede do Cândido Ferreira.

A associação é reconhecida como órgão de utilidade pública municipal e estadual, sendo filiada à Federação de Entidades Assistenciais de Campinas e ao Conselho Municipal de Assistência Social (Cayres et al., 2001), que objetiva o desenvolvimento e a expansão de oficinas de trabalho orientadas à reabilitação psicossocial por meio do estabelecimento de parcerias com os serviços de saúde conveniados com a Secretaria Municipal de Saúde (SMS), primordialmente o NOT e o SSCF, de acordo com os relatos:

E1.22 - A gente tem um contrato de comodato com o Cândido... Então a associação tem a sede aqui no espaço do Cândido também. E como é uma parceria, as oficinas funcionam nessa lógica da parceria com a saúde, então o Cândido também recebe do SUS um x lá pelas oficinas terapêuticas. E cede lugar, cede profissionais que acompanham.

Essa parceria com a SMS estabelece o pagamento de um valor determinado conforme número de participantes nas oficinas, o que denota uma certa dependência financeira dos recursos provenientes da administração pública. Embora o convênio com a Secretaria Municipal de Saúde estabeleça um número de vagas de 260, normalmente ocorre uma variação desse número, conforme os relatos: 
E1.1 - São 250 vagas que a gente tem, 260, desculpe, ampliou mais dez vagas. Isso é o que a gente tem conveniado com o SUS via a Prefeitura de Campinas que são essas 260 vagas nas Oficinas que tem o convênio aqui com o Cândido.

E1.2 - Não, sempre varia. No último faturamento que a gente fez, eu estava com 288 pessoas, então assim, é um número mínimo que a gente chama, tem que ter no mínimo.

As oficinas de trabalho funcionam no horário comercial, de segunda à sexta-feira, das $7 \mathrm{~h}$ às $17 \mathrm{~h}$, porém por vezes estendem um pouco a jornada de trabalho quando existe alguma encomenda grande ou algum evento durante o final-de-semana, que segundo os relatos, são fundamentais à demanda constante de produção nas oficinas:

E3.39 (processo de trabalho) - Então há anos que a gente vem participando de GIFTIS, que são as feiras de artesanatos, a nível nacional, que compramos os espaços e vamos duas vezes por ano, então hoje, ela já esta recebendo pedidos que demanda desde março até agosto. Agosto tem outro, de agosto vai pra dezembro, e assim a nossa demanda está intensa.

A equipe que compõe o NOT é multidisciplinar, atuando de maneira integrada (Cayres et al., 2001), sendo que os profissionais de nível superior desenvolvem diversas atividades relativas basicamente à assistência dos usuários e à produção nas oficinas. Compõem a equipe técnica do NOT: 12 técnicos de nível universitário que desempenham a função de coordenação das oficinas, um professor de Artes e uma médica (12h), ambos oferecendo suporte técnico aos coordenadores.

Além da equipe técnica, compõem o quadro de funcionários do NOT: 24 monitores de oficina, 1 monitor-coringa, 2 vendedoras, 2 auxiliares administrativos, 1 recepcionista, 1 auxiliar de enfermagem e 1 motorista. Entre estes últimos encontram-se um número de usuários que após desenvolvimento nas oficinas foram contratados como monitor pela Associação Cornélia ou pelo SSCF, por meio do chamado Projeto Parceria, conforme fragmentos abaixo:

E5.3 - Ele iniciou o tratamento na oficina mais ou menos 6 anos atrás, como usuário de álcool, período em que vivia na rua, como morador de rua, e após períodos de tratamento na oficina, e também na $N A D E C$, com recaídas e avanços, superou o vício da bebida e atualmente é funcionário do Cândido Ferreira, contratado como monitor marceneiro.

E6.18 - E tem outras pessoas que estão na parceria, que é um projeto também de oficinas do NOT, mas que tem essa parceria 
com o Cândido, com o serviço de saúde. Então eles passam a trabalhar em setores do hospital mesmo, na cozinha, na parte de higiene, e aí tem uma bolsa fixa.

Com relação à estrutura física, as oficinas do NOT funcionam em dois espaços distintos. Um localizado no próprio SSCF, situado num bairro mais afastado do centro chamado Sousas, de características mais rurais, e outro num prédio de 4 andares localizado na região central de Campinas, no bairro comercial Cambui, onde também funciona a loja Armazém das Oficinas, inaugurada em 2003 com o propósito de comercializar as peças produzidas pelos usuários de Campinas e Guarulhos (Armazém das Oficinas, disponível em http://www.armazemoficinas.com.br, retirado em 15/02/2009).

Essa ampliação das instalações físicas do serviço, inclusive para fora da instituição assistencial, num espaço localizado no centro da cidade, motivada pela expansão do projeto, demonstra um alinhamento com a proposta da desinstitucionalização como emancipação, que aponta a necessidade de inversão da lógica do assistencialismo que, em geral, caracteriza-se pela pobreza de recursos. Essa preocupação aparece nos fragmentos abaixo:

E1.4 - Então, hoje a gente tem utilizado de toda a quase estrutura que estava ociosa que tinha no Cândido e com a expansão depois pra outros espaços da comunidade, foi montada a Oficina centro que daí tem o espaço da loja e são três oficinas lá. É num prédio na região mais central.

E1.5 - Tem o prédio, ela entra no tipo térreo, tem a loja. Depois sobe um andar, e tem a Oficina de Nutrição, desce tem Vitral e Gráfica. Ele tem quatro pisos, na verdade. O prédio é grande lá.

No espaço do SSCF funcionam 9 oficinas de trabalho: Oficina de Vitral Plano, Oficina de Construção, Oficina de Vitrais, Oficina Agrícola, Oficina de Mosaico, Oficina de Marcenaria, Oficina de Velas, Oficina de Serralheria e Projeto Parceria; e no centro, além da Loja Armazém das Oficinas, são desenvolvidas 3 oficinas: Oficina de Culinária, Oficina de Papel Reciclado, Oficina Gráfica.

Algumas oficinas desenvolvem também parte de suas atividades fora do espaço do SSCF ou da Loja, como a Oficina de Culinária que oferece o serviço de buffet em eventos externos, levando não apenas os alimentos preparados pela oficina, mas também garçons (usuários treinados) para 
servir; a Oficina de Construção que realiza alguns serviços de construção civil em locais diversos; e também a Oficina da Horta, onde um dos três grupos desenvolve atividades de limpeza e manutenção de áreas verdes em condomínios ou residências privadas, conforme fragmento a seguir:

E4.13 (produção) - Depois nós temos o grupo da jardinagem, que a gente faz serviço externo e interno do Cândido também, moradia, CAPS, condomínio fechado, propriedade particular. Então nós fazemos serviço de jardinagem e de limpeza de terreno, o plantio de plantas diversas. Nós temos, inclusive, contrato fechado com 0 condomínio que a gente tem que fazer limpeza da calçada, roçar, limpar.

Essas atividades externas são identificadas como semelhantes ao trabalho cooperado, visto que se realizam fora dos espaços institucionais, de acordo com os fragmentos abaixo:

E1.8 - Na verdade, a Oficina Agrícola, a horta usa aqui o espaço do Cândido, e os grupos de jardim todos trabalham fora. Então hoje, eu acho que são os grupos mais próximos de ser um trabalho cooperado.

E1.9 - É, eles são, eles fazem jardim particular em casas, e eles estão com três condomínios com contrato fixo Então tem um grupo, dois grupos que trabalham num condomínio que chama Hermitage aqui e tem mais dois grupos que trabalham num outro condomínio que é o Botânico, que eles fazem limpeza de terreno, e a manutenção das vias públicas, que é calçada porque tem muita área verde. Isso é um serviço fixo que contratou e eles vão todos os dias pra lá, então eles se encontram aqui de manhã e vão trabalhar nesses lugares, nesses condomínios.

O contrato desses serviços que se assemelha à prestação de serviços é realizado juridicamente pele Associação Cornélia, segundo as frases abaixo:

E1.10 - Não é com o grupo. Eles contratam é com a Associação Cornélia.

E1.37 (contrato trabalhista) - Entre a Associação Cornélia com condomínio, não é nominal.

E1.11 - Faz o contrato com o que eles querem que faça a manutenção de 120 terrenos que eles tem lá, que deixe sempre limpo, podado.

E1.13 - aí esse grupo hoje são sete pessoas, que aí dão prioridade para cuidar desses terrenos, tem que fazer no mínimo de quinze terrenos por mês, daí faz a limpeza e tal.

E1.14 - Aí tem um outro grupo que eles querem que faça a manutenção das vias públicas. Aí é um outro contrato separado. 
Entretanto, a organização do processo de trabalho e a divisão de tarefas, são feitas conforme as demais oficinas, ficando sob a responsabilidade do coordenador ou do monitor da oficina, conforme os fragmentos abaixo:

E1.12 - Aí, aqui a gente divide quem que vai cuidar desse tipo de tarefa, aí vê quem que vai...

E1.15 - então, são mais lá dez pessoas que vão fazer isso, e aí vai com o monitor e o grupo, aí eles dividem as tarefas, aí tem quem usa a máquina, quem não usa a máquina, tem aí essa parte que é a divisão de funções: tem aquele que só consegue capinar...

Embora o NOT utilize as dependências físicas do SSCF, os equipamentos e maquinários, os materiais de consumo e os veículos (2 peruas kombis e um carro tipo fiorino), de acordo com os fragmentos, pertencem às oficinas, alguns foram doados e outros foram sendo adquiridos ao longo do tempo com recursos próprios da oficina ou da associação, uma vez que não são fornecidos pelo SSCF:

E1.16 (sobre os equipamentos) - É tudo da Oficina.

E1.27 (recursos da oficina) - que a gente tem hoje de recursos, é um projeto que já está há quinze anos aí, caminhando então quando, quando começa a oficina tem muito pouco recurso e ao longo do tempo vai se estruturando e foi melhorando.

E1.28 - A gente começa uma oficina de marcenaria que não tem quase material nenhum, com bastante dificuldade de fazer, depois a gente conseguiu uma doação de material de uma empresa que doou e a gente conseguiu comprar isso pra marcenaria, pra serralheria, pra várias oficinas. Então a própria oficina que vai agora mantendo, fazendo a manutenção, então vai comprando, às vezes a associação tem algum recurso e ajuda, empresta se não tem dinheiro, aí depois vai pagando, a gente vai fazendo...

E1.29 -Tem os equipamentos que viabiliza a produção, e tem o material de consumo, isso o cândido também não dá, a gente tem que comprar pela própria oficina.

A manutenção dos equipamentos também fica a cargo de cada oficina, cujos recursos são disponibilizados por meio de um caixa da oficina, organizado pela associação, segundo fragmentos abaixo:

E1.19 - Por exemplo, a Oficina Agrícola tem seu caixa, a serralheria, cada oficina tem um caixa dentro do caixa da associação, que é a oficina que coordena.

E1.30 (manutenção dos equipamentos) - É a própria oficina também, via associação, tanto se a oficina não tem saldo, quebrou uma máquina e ela precisa muito arrumar, a associação manda 
arrumar, aí depois às vezes o caixa fica negativo, depois fica positivo, a gente vai fazendo essa gestão com o grupo. Produziu um monte de coisa, mas nós vamos ter que comprar material porque nosso material está muito ruim, então, às vezes, turquesa pra cortar mosaico, videa pra cortar vidro. Às vezes tem um saldo no caixa, mas tem que esperar um pouco, não vai tudo pra bolsa porque senão depois a gente não tem ferramenta pra trabalhar... eles tem essa noção já.

Segundo os fragmentos a seguir, os recursos das oficinas são administrados de forma autônoma, conforme necessidade e interesse do grupo de trabalho, indicando uma aproximação com a organização característica das cooperativas, baseada no princípio da participação econômica de todos os cooperados, na qual o capital da cooperativa deve ser controlado democraticamente pelos sócios por meio de discussões e decisões coletivas (ITCP COPPE UFRJ, 2007).

E1.20 - Então a Oficina Agrícola ele tem um combinado lá eles fazem uma reserva pra férias, então de todo mês do saldo que tem a oficina e da bolsa que eles vão receber, eles deixam dez por cento sei lá pro fundo-reserva, que eles chamam, que é pra férias, pra retirada no final do ano quem não precisa tirar durante $o$ ano... então faz esse caixa e divide aí, conforme o contrato, pelas horas que trabalhou, pela função que desempenha e executa.

Cada oficina repassa $10 \%$ das vendas para um caixa geral da associação, possibilitando um fundo comum para despesas administrativas e também para a contratação de alguns profissionais (atualmente 5 monitores, 1 vendedor e 1 assistente social), segundo fragmento abaixo:

E1.21 - e a associação tem uma taxa administrativa que a gente instituiu que é pra despesas bancárias, despesas de contador, todas as despesas que a gente tem... Então toda oficina do que ela vende, ela, dez por cento das vendas fica no caixa da associação, que aí a gente mantém os veículos, paga seguro, paga contador, todas as despesas administrativas...

Esse aspecto organizacional também caracteriza 0 trabalho cooperado, entretanto, todo o capital de uma cooperativa deve originar-se pela contribuição igualitária dos sócios, além de configurar-se como propriedade comum, cujo controle financeiro é definido pelas assembléias onde todos os sócios participam democraticamente. Caso contrário pode caracterizar uma falsa cooperativa, conhecida no Brasil como coopgato ou coop-laranja, que além de burlar a legislação, oferecendo uma remuneração não equivalente aos direitos trabalhistas e onde os lucros não são divididos igualmente entre a direção e os associados, criam um tipo de cooperativismo 
vantajoso apenas aos que detém o poder, os dirigentes, resultando numa exploração inescrupulosa, devido à precarização das relações trabalhistas e à conseqüente eliminação dos direitos do trabalhador (ITCP COPPE UFRJ, 2007).

A questão da retirada e da distribuição de sobras numa cooperativa, portanto, é uma das mais freqüentes discussões dentro de uma cooperativa, não apenas porque diz respeito àquilo que cada um vai receber como também se relaciona com o futuro da cooperativa. Nesse sentido, deve-se garantir tanto a produção e circulação das informações entre os membros da cooperativa como também a sua participação nas decisões (ITCP COPPE UFRJ, 2007).

A forma de remuneração das oficinas do NOT é denominada bolsaoficina, cujo valor é definido pela quantidade de horas trabalhadas pelo oficineiro. Neste ponto, também constatamos uma aproximação com os princípios do cooperativismo, cuja remuneração dos trabalhos realizados deve ser proporcional ao trabalho realizado, contudo não pode exceder a três vezes o valor da menor remuneração dos cooperados, considerando também a base salarial da categoria, elemento não citado pelos entrevistados.

Nas oficinas do NOT, o valor da bolsa pode ser fixo ou variável, conforme decisão do grupo, dependendo dos recursos obtidos pela comercialização da produção, da quantidade de horas trabalhadas e da avaliação de desempenho de cada usuário de acordo com sua função dentro da divisão do trabalho, segundo fragmentos abaixo:

E1.31 (valor da bolsa) - A produção tal, a venda, o caixa etc.

E3.56 - porque eles são remunerados por horas trabalhadas, então aquele que não tem acima da média as horas trabalhadas, também, isso entra na avaliação...

E3.60 - Quando nós temos o resumo da parte, do extrato da oficina, o que pagou, o que ficou, o que conseguimos ter de receita, de despesas, e o que ficou de saldo final, é a hora da divisão.

E2.43 (valor da bolsa) - Ele ganha por hora trabalhada, então, eu fecho quantas horas a oficina funcionou no mês, e depois a gente conta a hora de cada um. Então $100 \%$, seria o 100\% das horas ali do mês... 
E2.46 - A gente tem uma bolsa padrão de quatrocentos e cinqüenta reais, então quem é o $100 \%$ ganha quatrocentos e cinqüenta. Mas ele tem quem ser $100 \%$ na avaliação e $100 \%$ nas horas.

Entretanto, como veremos mais adiante na análise do processo de trabalho, embora as sobras também sejam distribuídas entre os oficineiros, a avaliação de desempenho que define o valor da remuneração em geral é realizada pelo coordenador e pelo monitor, enquanto no modelo cooperado, a tabela de remuneração, incluindo os diretores, deve ser aprovada em assembléia geral, com a participação e decisão coletiva. A importância das assembléias gerais, portanto, relaciona-se com o princípio de participação coletiva e democrática no estabelecimento das políticas e na tomada de decisões sobre as questões centrais da cooperativa, como:

...as relativas à forma de gestão do empreendimento, à organização da produção, à forma de estabelecer relações com o mundo externo, ao seu crescimento e desenvolvimento, ao controle de finanças, ao acesso às informações (ITCP COPPE UFRJ, 2007, p. 28).

O modelo cooperado é apontado como referência de modelo de gestão, especialmente com relação aos princípios do cooperativismo que orientam a gestão democrática e livre, caracterizada pela tomada de decisões coletiva dos sócios, conforme afirmação abaixo:

O NOT funciona como uma "cooperativa". A equipe que o gerencia busca favorecer a participação democrática dos usuários em todas as etapas do processo de trabalho: na produção, venda, no processo de remuneração e, muitas vezes, na contratação de cuidadores (Cayres et al, 2001, p. 108).

No entanto, a forma de gestão do NOT não corresponde plenamente à forma de auto-gestão própria de uma cooperativa, em virtude da estrutura organizacional da instituição se configurar como uma associação filantrópica conveniada com a SMS para a prestação de assistência à saúde mental, onde não existe a figura do sócio ou cooperado, mas de usuários da rede de saúde mental, denominação que advém do modelo de organização dos serviços sanitários. E do papel de controle e gerenciamento de todos os momentos do processo de trabalho dos coordenadores, técnicos de saúde, que analisaremos na categoria processo de trabalho. Entretanto, a dificuldade de auto-gestão é atribuída pelos entrevistados às limitações dos 
usuários no sentido de romper com a lógica da assistência e da dependência:

E1.23 - É, partindo pra questão, por exemplo, da cooperativa, já fizemos cursos, várias capacitações pro pessoal, com relação à cooperativa, então essa é sempre uma questão que pega. É de até essas pessoas conseguirem se organizar autonomamente pra fazer isso, assim pra montar e se virar entendeu?

E1.24 - É cabem, tem muitas questões aí, até o medo de assumir alguma coisa... Então o que tem funcionado bem é esse modelo que a gente tem: tem um coordenador que lida com as relações, que faz essa ponte com o tratamento, com a saúde, é a referência um pouco desse usuário; o monitor que vai junto. $E$ as pessoas têm contratado, e tem sido tranqüilo assim...

Esse modelo de organização do trabalho nas oficinas, aparentemente se justifica pelos objetivos definidos pela instituição: profissionalização e geração de renda para inclusão social, conforme frases abaixo:

E1.45 - ...tem a capacitação, a geração de renda e a inclusão social que acho que são os objetivos, são os princípios que a gente tem, da inclusão, da capacitação e da geração de renda.

E1.60 (sobre os objetivos do NOT) - É resumindo é a inclusão social, a capacitação para o trabalho e a geração de renda.

Para atingir tais objetivos, segundo os entrevistados, a equipe técnica do NOT deve desempenhar duas funções consideradas correlatas: a habilitação para o trabalho e o atendimento às necessidades terapêuticas dos usuários.

E1.42 (projeto institucional) - O modelo de gestão eu diria que a gente funciona em moldes cooperativistas, mas que tem que caminhar junto com a questão terapêutica, também, a gente cumpre estas duas funções, da geração de renda e da função terapêutica também do trabalho e do acompanhamento das pessoas.

O fragmento acima corrobora com o projeto institucional definido pelo NOT que se baseia num funcionamento similar ao trabalho cooperado, entretanto dentro do campo da assistência cuja função do trabalho também se apresenta como intervenção terapêutica, afirmado no texto abaixo:

Neste sentido, o N.O.T. desempenha duas funções correlatas, de um lado, persegue a profissionalização e de outro, não se furta a atender as necessidades terapêuticas dos usuários. Faz a opção por abordar as duas vertentes, terapêutica e profissionalizante, entendendo que valorizar um aspecto em detrimento do outro traria perdas reais aos usuários (Domitti, Carnevalli, Bianchini, 2001, p.3). 
O trabalho no NOT é compreendido como uma forma de operacionalização de alternativas de intervenção que possibilitem processos de autonomia e de reabilitação psicossocial dos usuários da saúde mental, num espaço continente que permita a expressão da subjetividade, estimule as relações pessoais e respeite a potencialidade de cada usuário (Cayres et al., 2001).

Embora tanto os autores citados como os depoimentos dos entrevistados demonstrem uma coerência com o projeto institucional do NOT, a manutenção dessa vertente terapêutica do trabalho pelos projetos de reabilitação psicossocial nos processos de desinstitucionalização refletem uma confusão acerca da natureza da utilização do trabalho pela psiquiatria, que é percebida como uma contradição, segundo fragmento abaixo:

E1: Eu acho que não é tranqüilo e tem as suas contradições. Mas, tem sido possível, respeitar até as dificuldades desta população, os limites e estar caminhando, acho que não é completamente sem contradição nem super tranqüilo.

Como vimos na revisão da literatura, o sentido da utilização do trabalho é central na transformação do papel da assistência à saúde mental em direção à transformação da vida dos usuários e da representação social (determinada pela ideologia dominante) acerca do fenômeno da loucura.

A função terapêutica da atividade e do trabalho apóia-se na função de normalização psiquiátrica, presente desde sempre nas instituições psiquiátricas, desenvolvida também pela ergoterapia. Não se trata de negar os efeitos terapêuticos da reabilitação psicossocial que se utiliza do trabalho, mas de questionar a função e os valores morais e éticos que acompanham essa concepção, relacionada com a ocupação do tempo, condenação do ócio, obrigatoriedade do trabalho, disciplina do corpo e da mente pelo controle dos sintomas psiquiátricos, que entre outras conseqüências acaba por gerar uma dependência institucional e uma invalidação social do louco, como alguém incapaz de gerir-se por si próprio. Também não se trata de negar a assistência, mas de transformar essa relação histórica entre a assistência psiquiátrica e o trabalho institucional que serviu por muitos anos para a exploração e o controle dos desvios necessários à manutenção da ordem. 
Apesar dos discursos antimanicomiais das novas propostas de reformulação da assistência à saúde mental e suas correspondentes propostas reabilitadoras pelo trabalho, o risco se dirige à formulação de estratégias aparentemente mais humanitárias e inovadoras que sem refletir sobre a essência dos temas envolvidos podem reproduzir o papel de controle, subordinação, normatização e institucionalização do trabalho assistido na saúde mental, e assim, reproduzir o paradigma psiquiátrico e alienação do trabalho.

A relação entre assistência e trabalho e o sentido do trabalho no campo da saúde mental foi profundamente problematizada pela experiência da Psiquiatria Democrática Italiana, que em síntese, concluiu três possibilidades. A primeira relaciona-se à instituição total, que se funda na subtração da liberdade e subjetividade - jurídica, moral e econômica - da pessoa, sendo organizada para a produção da dependência, das relações de domínio e subordinação pessoal. As relações, portanto, são de natureza de dependência pessoal cuja meta principal é a invalidação como "desestruturação de si" (Leonardis, Mauri, Rotelli, 1995, p. 16).

Com o crescimento do Welfare State e o desenvolvimento das propostas de reforma psiquiátrica, que se definem como reformuladoras visto que se relacionam à desinstitucionalização, aos direitos civis e sociais, aos profissionais e aos pacientes como usuários, a assistência passou a fundar-se nos serviços comunitários organizados pela prestação especializada. Entretanto, para os reformadores italianos, essas relações continuam sendo fortemente assimétricas: por um lado está alguém que tem uma necessidade, um problema, um padecimento mais ou menos grave ou urgente e por outro, existe alguém que detém o saber-poder de responder. Este último detém o código para definir essa necessidade e do outro lado, aquele que se quiser uma resposta deve saber, poder e querer expressá-la segundo esse código. Sendo assim, a dependência se transforma, mas não desaparece:

Se transforma em dependência impessoal, institucional; se transforma em lealdade, submissão a ordem do discurso e às expectativas do comportamento do serviço e de seus especialistas. A subjetividade e liberdade da pessoa se reconhecem mediante a atribuição de um único requisito: a pessoa em questão é um 
assistido [...] as relações constitutivas desse segundo tipo são de lealdade institucional fundada na desconfiança e infantilização, e desembocam fundamentalmente na invalidação, entendida como redução da pessoa ao papel de assistido (Leonardis, Amauri, Rotelli, 1995, p. 16).

Pretendendo subverter essas duas finalidades que refletem o sentido último da relação assistência-trabalho como normatividade e adaptação social, os italianos, como vimos, propuseram a invenção de novas estratégias de utilização do trabalho por meio da constituição de empresas sociais cuja finalidade dirige-se ao desafio de ativar o papel dos destinatários da assistência, a pôr em jogo suas competências e responsabilidades a partir da reconstrução de intercâmbios sociais, "porque os direitos de cidadania se constroem materialmente e se traduzem, de maneira prática, em validação das pessoas mediante o cultivo de relações de confiança e a construção de condições de auto-estima" (Leonardis, Amauri, Rotelli, 1995, p. 17).

Essa questão do sentido do trabalho nas propostas de reabilitação psicossocial permeia todo o presente estudo, buscando problematizar sobre os elementos constituintes dos projetos de geração de renda e trabalho das propostas desinstitucionalizantes, caso contrário, corre-se o risco de reproduzir a alienação, submissão e domínio dos trabalhadores promovidos pela ideologia dominante não apenas no campo da saúde mental, mas também no campo do trabalho. Portanto, essa discussão também estará presente na análise das demais categorias apresentadas nesta pesquisa, uma vez que o projeto institucional definido pela instituição orienta o modo de funcionamento e de estruturação, bem como a organização do processo de trabalho do serviço.

Prosseguindo, por ser considerado um serviço da rede de saúde mental, o NOT objetiva também a consolidação de mudanças qualitativas na assistência psiquiátrica conforme as diretrizes do Ministério da Saúde sobre a Reforma Psiquiátrica Brasileira (Cayres et al., 2001) conservando, contudo, características próprias definidas pela política municipal de saúde mental e pela própria instituição, conforme fala:

E1.129 (relação com outros serviços da rede) - Eu acho que o NOT faz parte da rede de saúde mental querendo ou não, a gente está inserido nessa rede, a gente tem o papel do trabalho, da geração 
de renda, mas também tem essa função do cuidado. Então estamos integrados aí na rede.

Nesse sentido, sua relação com os demais serviços da rede de saúde mental do município se realiza por meio do sistema de encaminhamentos, basicamente dos Centros de Atenção Psicossocial e dos Centros de Saúde estabelecidos no território de abrangência, o município de Campinas:

E1.64 - Estar em algum serviço: CAPS, CAPS 3, CAPS AD, Centros de Saúde. Antes a gente recebia muito da PUC, do ambulatório da PUC, do ambulatório da UNICAMP, mas agora acho que a rede está mais focada nos CAPS e nos Centros de Saúde, então basicamente esses três são os fundamentais.

E1.65 (território) - Só Campinas. Hoje só Campinas. Já foi aberto à região, agora não é mais.

Portanto, o serviço NOT não pode ser considerado "porta aberta", pois embora exista a procura espontânea, o usuário de saúde mental deve estar inserido em algum serviço da rede para ser encaminhado às oficinas de trabalho, conforme discursos:

E1.62 - O encaminhamento que elas vêm, de estar em um serviço de saúde, isto é um critério...

E1.63 - Vem sempre por algum serviço... Às vezes vem por procura espontânea, às vezes está em algum serviço e vem por que "ah um meu vizinho está aqui", ou meu colega de grupo, então a gente fala: fala com sua referência, que importância que tem e aí encaminha $e$ começa. É para a população da saúde mental que está em acompanhamento em algum lugar.

O encaminhamento para o SSCF é definido conforme o projeto terapêutico individual elaborado no serviço de referência, onde se discute a importância do trabalho na vida do usuário. Mas a discussão especifica do trabalho no processo de reabilitação psicossocial é função do NOT:

E1.89 (definição do projeto terapêutico) - Com o usuário, ele é formulado lá, aí é dentro do projeto dele tem a questão do trabalho. $E$ aqui, então, a questão do trabalho e das outras questões vai desenvolver aqui. Vai discutir com ele, faz o contrato aqui, aí vai ver o que ele vai aprender a fazer, o que ele dá conta de fazer.

Como principal critério de inserção e permanência, a manutenção do tratamento no serviço de origem, faz parte do contrato estabelecido com o usuário, quando também se combina a freqüência de participação no NOT. Entretanto, a comunicação entre os serviços se faz no momento do encaminhamento feito por escrito e por meio de ligação telefônica, e 
esporadicamente nos casos de maior dificuldade de manejo, se a equipe do NOT estiver encontrando dificuldades no desenvolvimento da atividade, mas somente se estas forem relacionadas a outras questões que ultrapassam o papel da oficina. Algumas vezes, nesses casos, é realizada uma supervisão clinica do caso com a referência terapêutica do usuário e a equipe do NOT:

E1.82 - O encaminhamento é por escrito, mas não extingue a necessidade de um contato, quando ele começa na oficina sempre tem um contato pessoal entre o coordenador e a referência lá do serviço que ele está sendo atendido.

E1.84 (reuniões com profissionais de outros serviços) - São pontuais: quando a gente está tendo alguma dificuldade com algum caso que é de algum serviço e a gente não está conseguindo resolver entre os técnicos, a gente acaba pedindo supervisão clínica do caso, aí faz em parceria com o serviço, ou faz no serviço ou faz aqui, que a gente tem também uma supervisão clínica, um supervisor que dá este suporte.

E1.86 - Geralmente acaba chamando a referência, ou a gente vai numa supervisão que aquela equipe pediu. Porque tem caso que a gente não consegue resolver, nem aqui nem lá, fica pipocando entre os dois lugares. Essa relação é bem próxima...

Sendo assim, a participação do usuário nas oficinas é definida por ambos os serviços (NOT e serviço de tratamento) considerando o projeto terapêutico individual, onde a intensidade de acompanhamento do usuário pode variar conforme necessidade terapêutica do caso:

E1.87 (rotina do usuário) - Aí tem de tudo. Tem aqueles que é uma rotina quinzenal, outros que é uma rotina mensal, tem aqueles que é duas vezes por semana que vai ao CAPS, outros uma vez só, então a gente tem de tudo, assim. Depende do contrato de cada caso, é individual.

E1.88 - Quando a gente faz o contrato com o usuário, a primeira coisa é qual o compromisso que ele tem no CAPS. Acontece muito assim, quando ele começa, ele tem compromisso lá três vezes por semana, aí depois ele vai lá e duas vezes está bom, acha que uma vez, às vezes diminui isso... Reduz lá e fica mais aqui. E aí, quando a gente tem questões que não está conseguindo lidar, a gente senta, conversa, faz junto.

De acordo com os fragmentos de discurso, podemos concluir que 0 trabalho tanto é entendido como um instrumento terapêutico, associado ao tratamento psiquiátrico, assim como um elemento importante da vida concreta dos usuários, na perspectiva da atenção e da reabilitação psicossocial. Essa contradição da presença desses dois paradigmas antagônicos na relação trabalho e saúde mental também se expressou no 
projeto institucional definido pela instituição e apontado pelos sujeitos entrevistados.

Na divisão de funções entre os serviços da rede de saúde mental, ao NOT cabe o papel de promover ações de reabilitação psicossocial por meio do trabalho, embora, parafraseando um dos entrevistados, o serviço não se furte a atender as necessidades terapêuticas do oficineiro. Entretanto, se estas forem consideradas alvo de acompanhamento mais especializado e intensivo, não relacionadas ao trabalho, esta necessidade será encaminhada para ser desenvolvida pelo serviço de tratamento:

E1.91 (sobre outras necessidades além do trabalho) - Daí volta para o CAPS, para a referência que está lá, conversa, discute, olha está acontecendo isso. Ou é um atendimento individual, que se pode fazer para melhorar, porque às vezes ele vem com tantas coisas que também não da conta de ficar ou de fazer as atividades, às vezes está ansioso com alguma questão de casa e aí traz isso tudo, o coordenador, o monitor ali, até o grupo, porque coloca para o grupo, mobiliza o grupo...

E1.97 - quando é psicoterapia individual vai dirigido para o CAPS, isso a gente não dá conta. Isto é o que tem que ser feito no CAPS, se a gente for cuidar de tudo... Mas o que aparece, assim, de pontual se escuta, às vezes se resolve com pouca coisa, às vezes não.

E1.98 - Alivia e dá seqüência. Então a gente não se furta a ouvir, tem que ouvir. Se aparece aqui chorando, coisa assim, até a auxiliar de enfermagem escuta, ou eu escuto e então melhorou e volta para oficina e segue o dia. Depende do caso.

O acesso ao serviço, os critérios de inserção e permanência bem como as funções especificas do NOT no desenvolvimento das oficinas serão aprofundados posteriormente, durante a análise dos elementos de estruturação do serviço e da categoria processo de trabalho. Por hora, nos interessa situar o leitor quanto ao projeto institucional do NOT, seu funcionamento mais geral e sua localização na dimensão estrutural na política de saúde de Campinas. Esse tema é explicitado no fragmento de texto abaixo:

E1.135 (sobre políticas públicas) - Com relação às políticas públicas, eu acho que o NOT contribui nas discussões, então nós estamos nesse momento retomando a questão do convênio do Cândido com a prefeitura e o estabelecimento das novas metas. Uma questão que já está pautada com a coordenadora de saúde mental é discutir a questão das oficinas, tem um pedido dos distritos, do pessoal da saúde mental, de ampliar, de descentralizar, então acho que a gente participa na elaboração dessa política, ora com mais atuante e ora quando o tema não é tão... acho que os 
temas de CAPS, urgência/emergência sempre tomam à frente das questões de oficinas, centro de convivência... Mas a idéia é estar participando dessas discussões.

Com relação às políticas públicas, o NOT participa do grupo intersetorial que discute o desenvolvimento da Economia Solidária no município, estabelecendo parcerias com outras secretarias para 0 desenvolvimento de ações intersetoriais voltadas à geração de renda e ao trabalho:

E1.130 (sobre parcerias e políticas públicas) - isso faz parte do grupo que discute a economia solidária, que organiza a feira de economia solidária do município...

E1.131 - na Secretaria de Assistência aqui de Campinas tem um departamento que é de trabalho e renda, e a gente também tem parcerias, também estão no grupo que discute economia solidária no fórum, enfim, tem uma relação aí de parceria.

E1.133 - então tinha um grupo intersetorial que estava discutindo a questão até de uma incubadora municipal, que estava a gente aqui do NOT, o pessoal da geração de renda da Casa das Oficinas, os apoiadores de saúde mental, o pessoal da assistência, que acompanha esses grupos, estava o pessoal da educação, estava nessa discussão, então está meio esfriado assim agora, mas a gente tem tentado...

E1.134 - e tem um grupo que é um fórum que discute oficinas de trabalho e geração de renda e centro de convivência, então ora está só centro de convivência ora só oficina de trabalho, começou tudo junto depois ficou quinzenal, que também era pra ter reunião essa semana, não teve; essa a gente tem tentado participar aí ativamente, até pra pensar aí nos encaminhamentos políticos.

Embora o planejamento e desenvolvimento de ações no campo da Economia Solidária - criação de uma incubadora municipal, promoção de cursos de capacitação e estabelecimento de um espaço físico comum aos empreendimentos solidários -, sejam considerados importantes, a participação do NOT nesse grupo de discussão, segundo avaliação do sujeito entrevistado, encontra-se enfraquecida devido à desarticulação do grupo e também pelo fato da pessoa responsável por acompanhar tais questões encontrar-se (na ocasião da entrevista) afastada do serviço:

E1.132 - Hoje o grupo de geração de renda aqui de Campinas está meio capenga, a $X$ saiu, está doente, está afastada...

E1.136 - Nesse momento está meio paralisado, mas já se formou uma comissão pra discutir isso, intersetorial incluindo a educação, a saúde, a assistência social, até a cultura, com representações de vários segmentos tanto da prefeitura quanto dos serviços e parou a discussão, acho que estava bem aquecida no ano passado, esse ano, 
com a saída da $X$, que também estava a frente disso, o afastamento deu uma desaquecida.

E1.137 - Mas a idéia é retomar esse fórum de discussão, porque uma das propostas desse grupo que estava discutindo era tentar montar uma itcp municipal; itcp é um centro de treinamento que fosse do município, pra não depender só da questão da UNICAMP, em termos de capacitação.

E1.138 - tinha uma proposta também da prefeitura de reforma de um espaço físico grande que tem no centro da cidade, e ceder esse local pros empreendimentos solidários do município, aí entram os da saúde mental, então a gente tem tentado protagonizar nesse sentido, em estar participando dessa coisa mais ampla.

Mesmo com as dificuldades relatadas, o NOT demonstra um alinhamento com as diretrizes do Ministério da Saúde com relação ao estabelecimento de parcerias no planejamento e execução de ações voltadas à inclusão social pelo trabalho, especialmente com o campo da Economia Solidária, que, segundo o mesmo documento, compartilha dos mesmos princípios éticos e políticos do movimento da reforma psiquiátrica no que tange à reinserção social das pessoas em desvantagem.

É clara neste marco referencial a crítica à dura lógica capitalista de produção incessante de vitoriosos e derrotados. Como horizonte da Economia Solidária está a instauração da solidariedade como norma social e a construção de empreendimentos coletivos e autogestionários como resposta à exclusão social. (Brasil, 2005, p.39).

Nesse aspecto, contudo, podemos refletir que as parcerias intersetoriais do NOT estão restringidas ao campo da economia solidária, quando poderiam ser ampliadas para outros setores públicos e outros espaços comunitários como sindicatos de trabalhadores, associações de usuários e familiares, associações de moradores, instituições de ensino, entre outros, no sentido de contribuir com o debate e elaboração conjunta de políticas de saúde, de educação, de seguridade social, de desenvolvimento econômico e sustentável, e de inclusão social pelo trabalho (não apenas no formato de oficinas de trabalho ou de geração de renda) que possam servir de enfrentamento aos elementos constitutivos da dimensão estrutural do modo de produção capitalista que, como sabemos se caracteriza pela exploração e mercantilização do trabalho humano, pela precarização das condições de vida dos trabalhadores, e pela redução dos postos de trabalho, 
atingindo a cada dia parcelas significativas da população mundial, especialmente com o advento recente da crise do sistema capitalista.

\section{Definição da missão institucional}

A missão institucional do Serviço de Saúde Dr. Cândido Ferreira, definida pelo processo de transformação operado na instituição, seria de implementar as diretrizes da RPB - desospitalização, desinstitucionalização e garantia da cidadania dos doentes mentais -, a partir da manutenção do caráter público do serviço e sua efetiva inserção na rede de serviços do SUS (Onocko, Amaral, 2002).

O papel do Núcleo de Oficinas e Trabalho, nessa perspectiva, seria de contribuir nas mudanças qualitativas da assistência psiquiátrica a partir do desenvolvimento de intervenções especializadas relacionadas com a reabilitação psicossocial no eixo trabalho:

Considera-se que através da oportunidade de trabalhar e ganhar pelo trabalho a pessoa recupera a possibilidade de ampliar seus conhecimentos, suas reflexões, transformar suas ações ou modificá-las diante das necessidades, passando a ser reconhecida como capaz de produzir e estabelecer relações sociais (Cayres et al., 2001, p. 107).

Nesse sentido, a participação nas oficinas de trabalho teria como objetivo a reconstituição da subjetividade do individuo portador de transtorno mental que fora vitimado pelo preconceito, pelo isolamento social e pelo afastamento do mundo do trabalho em virtude de longas internações. A partir do estabelecimento de uma nova cultura de relações sociais que possibilite a produção da sociabilidade, da comunicação, da autonomia, o contato com a cultura e a aquisição de novos conhecimentos, o NOT define como horizonte estratégico a promoção da participação e a reinserção social dos sujeitos com sofrimento mental (Cayres et al., 2001).

Em síntese, o projeto institucional está definido pelo texto abaixo:

Além da habilitação para o trabalho, o NOT propicia a convivência, a ampliação da rede social, a formação profissional e a geração de renda aos participantes, proporcionando assim a inclusão social pela atividade. O acompanhamento dos usuários é realizado por profissionais da área da saúde mental, que estimulam o desenvolvimento das potencialidades e habilidades individuais, a interação grupal e os princípios cooperativos democráticos (Serviço de Saúde Dr. Cândido Ferreira, disponível em http://www.candido.org.br, retirado em 09/09/2007). 
Segundo a literatura cientifica que aborda a questão do projeto institucional, nem sempre as finalidades apontadas pela instituição ou as intervenções planejadas correspondem às ações concretas desenvolvidas no processo de trabalho dos serviços. Os estudos de psicopatologia do trabalho, por exemplo, afirmam a existência de uma "defasagem irredutível" entre a organização prescrita do trabalho e a organização real do trabalho. Em outras palavras, existiria uma diferença entre a concepção e a execução do trabalho, uma vez que seria impossível ao trabalhador cumprir os objetivos da tarefa na execução do trabalho se ele seguisse rigorosamente as prescrições, as instruções e os procedimentos (Dejours,1999).

A esse respeito, o escritor português Saramago (2000) utiliza, em sua obra literária que retrata 0 trabalho na modernidade, $A$ caverna, uma imagem para diferenciar o projeto do trabalho (finalidade do processo de trabalho) do seu resultado concreto (produto do trabalho), que segundo ele nunca corresponderia exatamente aquilo que se planejou mentalmente. Afirma o autor que tal fato seria decorrente de que os dedos das mãos teriam cérebros próprios que pensam e agem autonomamente e muitas vezes contrariamente ao cérebro da cabeça, responsável pelo planejamento ou idealização do trabalho.

Os serviços de saúde não fogem a essa regra, uma vez que nem sempre organizam o processo de trabalho com base no planejamento dos resultados e na definição dos instrumentos de intervenção e do papel de cada trabalhador no trabalho em saúde (Pires, 2008).

Tomando emprestada essa imagem de Saramago, passaremos à analise das ações desenvolvidas pelas oficinas de trabalho do NOT, na visão dos coordenadores destas oficinas, bem como suas concepções sobre alguns conceitos fundamentais ao desenvolvimento das atividades (trabalho, reabilitação psicossocial, cooperativa), ou seja, os cérebros dos dedos das mãos, à luz daquilo que está definido como finalidade da instituição (desospitalização, desinstitucionalização, cidadania), ou seja, daquilo que foi planejado pelo cérebro da cabeça. 
Não de trata de fazer julgamentos ou avaliações de natureza moral ou mesmo cientifica, mas de tomar essa instituição particular como referência para análise de caso com o propósito de contribuir com o processo coletivo de debate sobre as questões relativas ao trabalho como inclusão social dos usuários de saúde mental e da formulação de diretrizes norteadoras para o desenvolvimento de ações de reabilitação psicossocial no eixo trabalho no contexto da Reforma Psiquiátrica Brasileira.

Somos conscientes das dificuldades e desafios que se apresentam aos processos de transformação e seus protagonistas, especialmente no que tange a construção de consensos e conceitos comuns, bem como a operacionalização dos mesmos no desenvolvimento de práticas transformadoras da realidade, que na postulação de Marx (s/d), estão sempre dialeticamente carregadas de contradições e de elementos da nova forma e também da velha forma. É sobre esse processo dialético de transformação que buscamos nos fundamentar na análise deste caso - as oficinas de trabalho do Núcleo de Oficinas e Trabalho -, considerando que estas práticas estão em constante processo de reformulações.

Um dos desafios desse processo de reformulação da assistência ocorrido no SSCF diz respeito à construção de consensos sobre a missão de cada unidade de produção, dificultada pela rotatividade de profissionais decorrente da crise financeira permanente enfrentada pela instituição. Outra dificuldade estaria relacionada à operacionalização dos resultados do planejamento numa conjuntura adversa tanto interna quanto externa. A necessidade de mudança institucional também se traduziu no desafio de constituir sujeitos coletivos que se apropriassem do novo projeto (Onocko, Amaral, 2002).

Fazem parte desse sujeito coletivo, no caso do NOT, o conjunto dos coordenadores das oficinas de trabalho, estes últimos sujeitos desta pesquisa, considerados porta-vozes e protagonistas do projeto institucional, na imagem de Saramago, os cérebros dos dedos das mãos, que transformam a missão institucional em ações concretas, que realizam o trabalho real. 


\section{MODO DE ESTRUTURAÇÃO DO SERVIÇO}

Um dos temas mais tratados e problematizados na organização de um sistema de saúde para todos estaria relacionado ao modo de estruturação e gerenciamento dos processos de trabalho nos diversos tipos de estabelecimentos que ofertam serviços de saúde comprometidos com a defesa da vida individual e coletiva (Merhy, 2002).

No campo da saúde coletiva, este tema faz parte de uma discussão
muito instigante, já algum tempo, travada entre vários pensadores e
militantes da reforma sanitária brasileira. Paradoxalmente, porém,
entendemos que este é exatamente um dos grandes nós críticos
das distintas propostas vivenciadas nestes últimos anos, que
apostam e apostaram na mudança da direção efetiva do atual
modelo tecno-assistencial das políticas de saúde, que tem se
mostrado comprometido com muitos tipos de interesse, exceto com
a saúde dos cidadãos (Merhy, 2002, p. 71/2).

Nesse sentido, a tarefa de transformar o modo de produzir saúde no Brasil, de transformar o atual modelo tecno-assistencial, é uma tarefa coletiva do conjunto dos trabalhadores de saúde que se traduz em mudanças cotidianas do seu modo de operar o trabalho no interior dos serviços, caso contrário de nada valeriam as propostas de reformas macroestruturais e organizacionais se estas não fossem concretizadas pelos operadores (Merhy, 2002).

Sendo assim, são inúmeras as iniciativas de construção de processos de intervenção institucional voltados à produção de reformas no sistema de gestão dos processos de trabalho em saúde que tomem como referência principal o interesse dos usuários, em outras palavras, as suas necessidades de saúde.

Para compreender e refletir sobre o trabalho no dia-a-dia dos serviços de saúde, "o que lhe é próprio, quem trabalha e como o faz, para que, por que, a quem serve e como serve" (Merhy, 2002, p.73) utilizaremos uma ferramenta de análise denominada pelo autor de fluxograma analisador do modelo de atenção de um serviço de saúde, que tomaremos emprestado para analisar alguns aspectos do modo de estruturação do serviço NOT.

De maneira simples, o autor define o fluxograma como um diagrama utilizado para "desenhar um certo modo de organização de um conjunto de processos de trabalho, que se vinculam entre si em torno de uma certa 
cadeia de produção" (Merhy, 2002, p.73). Como um diagrama sintético, o "fluxograma-resumo", que permite esquematizar de maneira simples, os processos-chave que ocorrem e caracterizam um determinado serviço de saúde, também servindo de guia para a construção de outros processos nele presentes.

Em geral, caracteriza qualquer serviço assistencial de saúde a sequência mostrada no diagrama a seguir (Merhy, 2002):

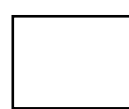

ENTRADA

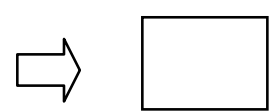

RECEPÇÃO

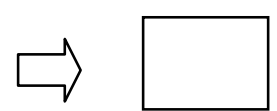

DECISÃO DE OFERTAS

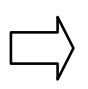

CARDÁPIO
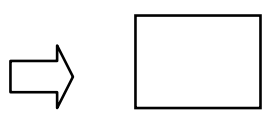

SAÍDA

A entrada no serviço é analisada pelo movimento que se faz na "porta" de uma determinada unidade de saúde, onde alguns dos usuários passam para a etapa de recepção enquanto outros não. Vamos denominar este momento do processo de acesso, cuja caracterização permitirá a identificação e análise também de um dos elementos constituintes da estruturação e gestão do processo de trabalho em saúde: o objeto de trabalho.

\subsection{Acesso}

A palavra acesso, ou acessibilidade, é comumente utilizada no campo da saúde pública para designar a possibilidade de utilização dos mais diversos serviços de saúde por parte dos usuários, sendo uma das principais diretrizes e princípios do SUS. A garantia de equidade de acesso a todos os serviços de saúde pública é definida pelo Sistema de Saúde Único por meio das Leis Federais 8.080/1990 e 8.142/199023 que consideram a saúde como direito de todos e dever do Estado. (Constituição da República Federativa do Brasil, 2009).

${ }^{23}$ A Lei 8.080 dispõe sobre as condições para a promoção, proteção e recuperação da saúde, organização e o funcionamento dos serviços correspondentes e a Lei 8.142 dispõe sobre a participação da comunidade na gestão do Sistema Único de Saúde - SUS e sobre as transferências intergovernamentais de recursos financeiros na área de saúde. 
No caso dos usuários de saúde mental, o relatório final da III Conferência Nacional de Saúde Mental (Sistema Único de Saúde, 2002), reafirmou não apenas os direitos de acesso a todos os serviços de saúde do SUS, bem como a meta de garantia e melhoria de acesso aos diversos bens e serviços da sociedade: trabalho, creche, profissionalização, educação, lazer, escola, moradia, transporte, segurança publica, lazer, saneamento básico, incluindo também a garantia do acesso às informações.

O acesso, portanto, aos serviços de saúde mental está pautado nos mesmos princípios que orientam a organização dos serviços de saúde: universalidade, equidade, integralidade das ações, descentralização dos recursos e controle social.

Segundo o Ministério da Saúde (2005), tanto o modelo hospitalocêntrico quanto 0 dos ambulatórios de especialidades são incompatíveis com a garantia da acessibilidade, uma vez que se caracterizam pela concentração de recursos e pela baixa cobertura. $O$ documento defende a potencialização da rede básica ou atenção primária de saúde como condição necessária à efetivação da acessibilidade na abordagem das situações de saúde mental. A cooperação e a articulação intersetorial também possibilitariam um melhor acesso à prevenção e ao tratamento.

Para a OMS (2001), a atenção em saúde mental deve ser baseada na comunidade, facilitando não apenas o acesso mas também o atendimento de múltiplas necessidades dos indivíduos, por meio de uma ampla gama de serviços. A OMS recomenda também o manejo e tratamento de transtornos mentais no contexto da atenção primária, o que possibilitaria ao maior número de pessoas ter acesso facilitado e rápido aos serviços.

Entretanto a idéia de comunidade proveniente da psiquiatria comunitária "pode ser um grande deserto, pode ser um lugar de anomia" (Rotelli,1994, p. 155), enquanto que no território existiriam forças vivas onde se estabelecem as relações concretas e imaginárias entre as pessoas, com os objetos, com a cultura, cujos saberes devem ser incorporados pelas práticas desinstitucionalizantes. 
Como já dissemos anteriormente, o sistema de saúde de Campinas está organizado de forma regionalizada e hierarquizada. Dentro dessa lógica, o NOT é definido pela SMS como um serviço de maior complexidade, onde $o$ acesso se realiza por meio do encaminhamento de algum serviço de atenção básica, "porta de entrada" ao sistema, ou de nível secundário, que disponham de assistência à saúde mental.

E2.8 (inserção) - todos eles chegam por meio de encaminhamento, dos vários serviços de saúde, normalmente do SUS, alguns vêm por particulares, mas normalmente do SUS de Campinas.

E4.17 - os oficineiros, os usuários, eles são encaminhados pelo serviço da rede de saúde mental de Campinas, até mesmo pelo posto de saúde, qualquer atividade, até mesmo particular, UNIMED...

E8.24 - o usuário chega aqui encaminhado da rede de saúde mental, não necessariamente pública.

Sendo assim, o processo de inserção do usuário de saúde mental ao NOT está necessariamente condicionado à sua inclusão em algum serviço de saúde seja da rede básica como os Centros de Saúde, seja dos serviços especializados de nível secundário, como os Centros de Atenção Psicossocial ou algum serviço de atenção psiquiátrica da rede privada.

E3.3 - o processo da inserção se dá através de encaminhamento da rede pública, principalmente dos centros de saúde em que há atendimento psiquiátrico e do centro de atenção psicossocial...

E5.11 - O processo de inserção inicia-se com um encaminhamento realizado pelo serviço da rede pública, como centro de saúde e CAPS, e também por profissionais da rede particular, como UNIMED e clínicas que trabalham com usuários de substâncias psicoativas.

Portanto, um dos principais critérios para encaminhamento do usuário ao NOT, que também será apontado como um critério para sua permanência na oficina, trata-se da inserção e da manutenção do tratamento psiquiátrico, independente do serviço de assistência.

E3.30 - Então, se ele não faz adesão ao tratamento, não dá também para ficar no NOT.

E2.30 - a gente pede pra que todos que participam da oficina estejam em algum tipo de tratamento.

E6.31 (sem tratamento) - Aí ele nem entra. Ele já passa pela triagem. 
Além da adesão ao tratamento, outro critério para o encaminhamento do usuário ao NOT relaciona-se à estabilização do transtorno mental. Além de averiguar a manutenção do tratamento, o processo de inserção também objetiva a checagem da condição psiquiátrica do usuário, que deve apresentar um quadro estável, sem a presença de sintomas agudos, caso contrário será re-encaminhado ao serviço responsável pela atenção, conforme os fragmentos de textos temáticos abaixo:

E6.21 - Então a pessoa tem que estar estabilizada, não que ela ao longo do tempo não possa ter uma crise, mesmo estando inserida na oficina, porque daí, a gente conversa com as equipes, se precisar de uma internação saí e depois volta pra oficina, então, isso acontece.

E6.24 - Mas se encaminha e a pessoa não está legal, a gente liga pra essa referência que encaminhou, conversa, às vezes fala: ó, às vezes é melhor dar uma intensificada no tratamento pra depois num outro momento ele retornar aqui no NOT, fazer uma outra triagem, então a gente faz esse encaminhamento.

E1.72 (critérios para encaminhamento) - Estar estabilizado. Tem gente que não toma medicação ou toma muito ou pouca, e pode não estar tomando, tem uns que começam, depois tira a medicação e continua bem, estabilizado. Então um critério é estar com o quadro compensado pra começar...

E4.42 - quando eles não estão bem, quando eles não estão estabilizados, daí a gente encaminha de novo pro serviço de origem, pede um respaldo, e eles não são impedidos de retornar pra triagem e voltar pra qualquer oficina.

Essa obrigatoriedade de inserção no tratamento psiquiátrico se fundamenta no projeto institucional do serviço que se baseia como veremos adiante numa concepção de reabilitação psicossocial pelo trabalho como continuidade e complemento das intervenções terapêuticas dos serviços.

E por fim, o grau de autonomia do usuário também é um fator a ser considerado, tanto pelo serviço que encaminha quanto pelos coordenadores, como critério de acesso ao serviço, principalmente quanto à possibilidade de locomoção do usuário:

E6.20 - porque a pessoa tem que ter um mínimo de autonomia pra estar numa oficina. Porque eles vêm sozinhos de ônibus pra cá.

E6.22 - Mas ele tem que ter o mínimo de autonomia assim, andar sozinho, pegar ônibus sozinho, pra conseguir vir pra cá, e pra conseguir estar em grupo também, porque se ele não tiver legal não tem como ele ta no grupo. 
E6.23 - Porque quando encaminham pra gente, normalmente encaminha a pessoa quando ela já ta com mais autonomia.

O encaminhamento feito por escrito nesse sentido deve conter algumas informações de natureza clínica consideradas importantes: história psiquiátrica, diagnóstico, medicação utilizada, história de vida. Essas informações serão também verificadas durante a triagem, primeiro encontro do usuário com o serviço, que é realizada semanalmente pelos coordenadores das oficinas, como relatam os textos a seguir.

E3.5 (triagem) - os mesmos coordenadores de oficina daqui fazem o acolhimento dessas pessoas encaminhadas, e são encaminhadas com o relatório médico em que consta o diagnóstico e, minimamente o pouco do histórico e a medicação que faz uso.

E8.25 - Então os oficineiros, eles vêm encaminhados do serviço de saúde mental, da rede de saúde mental. E passam por uma triagem, que é feito pelos coordenadores das oficinas, onde colhem dados pessoais, histórico da doença, tratamento, um pouco da história de vida, das relações familiares, histórico profissional.

E1.170 (sobre o encaminhamento) - Encaminho Fulano de tal que faz acompanhamento neste serviço por tais e tais motivos, tem atendimento tais dias, às vezes tem 2 ou 3 vezes por semana, às vezes tem uma só, é... se faz uso de alguma medicação, qual que é o diagnóstico, com quem mora, geralmente tem um breve relato do caso assim, da vida da pessoa.

E3.6 (triagem) - pra dar esse primeiro acolhimento informando assim o que é o projeto, tirando deles onde eles conheceram sobre - NOT, como foi que ele está sendo encaminhado, em que momento ele está na vida e o conhecimento in loco...

Essa investigação descrita pelos entrevistados sobre o processo de inserção nos remete à discussão sobre a função disciplinar da anamnese clínica (interrogatório) como um dos mecanismos do poder psiquiátrico estudado por Foucault ${ }^{24}$ cuja finalidade estaria relacionada à atribuição de uma identidade doente, buscando na história passada os signos anunciadores da doença como anomalia, para estabelecer um cruzamento entre responsabilidade e subjetividade, ao fazer com que o paciente reviva a doença diante do poder psiquiátrico, na qual as ações e faltas serão configuradas como sintomas da doença, que deverá ser aceita pelo paciente

${ }^{24}$ Para um estudo sobre o poder psiquiátrico e das relações de saber-poder na psiquiatria, ver as obras do autor publicadas com os títulos: O poder psiquiátrico (2006), Vigiar e Punir (1987), Microfísica do Poder (1995) e O nascimento da clínica (2001). 
como o reconhecimento de ser controlado e dominado por essa doença (Canoni, 2009).

\begin{abstract}
Esta técnica não pode ser entendida a não ser dentro da lógica das estratégias e mecânicas de poder: atribuição de identidade, diferenciação normalidade-anormalidade, estabelecimento de faltas e responsabilidades e, finalmente, atribuição da loucura. E é no interior dessas estratégias de poder que a psiquiatria encontra sua razão de ser. $O$ interrogatório possibilita o reconhecimento do doente como louco, mas possibilita também o reconhecimento do próprio saber psiquiátrico (Canoni, 2009, p. 100).
\end{abstract}

Nesse sentido, esse primeiro encontro no serviço caracteriza-se por um momento de recepção no serviço, agendado previamente por telefone com a referencia terapêutica, que não apenas receberá o usuário informando-lhe sobre o funcionamento do serviço, mas também avaliará a sua condição para ingresso nas oficinas, conforme os critérios já citados. Destarte, essa recepção no serviço alinha-se mais ao modelo de triagem clínica, como referido, não por acaso, nos discursos dos entrevistados:

E3.4 - Então eles nos encaminham, e através de um telefonema, nós agendamos o dia da triagem...

E2.9 - Passam por uma triagem, é toda quarta-feira de manhã e a tarde, cada coordenadora tem um período, então eu faço...

E2.10 (triagem) - Eles são encaminhados para a triagem. Então a gente senta, têm um papel de triagem, a gente anota todos os dados, anexa encaminhamento, eles escrevem alguma coisa que eles pegam, assim do trabalho, o que eles imaginam, se eles se conhecem, às vezes uns querem desenhar.

E4.18 - eles passam por uma triagem, que nós fazemos com eles. É uma coleta de dados, inicialmente...

E11.14 - a inserção, a gente recebe todas as pessoas, pela triagem que realizamos...

O sentido de acolher significa, entre outras coisas, dar crédito a, dar ouvido a, tomar em consideração. Não se trata apenas de receber bem, mas de interagir, de relacionar-se, de estabelecer vínculos (Zauhy, Mariotti, 2002). O acolhimento, sobretudo, vincula-se à idéia de que:

...a relação entre os cidadãos trabalhadores de saúde e os cidadãos que buscam atendimento não é uma interação mecânica entre "usuários" (utilizadores) e "agentes" (utilizados). É um relacionamento de troca, participação, co-produção... (Zauhy, Mariotti, 2002, p.75).

Contudo, este momento de encontro entre "um usuário, portador de uma dada necessidade de saúde, com um trabalhador, portador de um 
arsenal de saberes específicos e práticas, não necessariamente se caracteriza por um encontro de situações equivalentes” (Merhy, 2002, p. 76). O primeiro carrega consigo a representação de um dado problema de saúde e espera obter uma relação de sinceridade, responsabilidade e confiança quanto à definição da intervenção para possivelmente solucionar seu problema. O segundo também procura algo nesta relação, também tem necessidades, mas não necessariamente relacionadas à expectativa do usuário. Esta situação está representada nos fragmentos que seguem:

E10.17 - Aí normalmente eu separo uma quatro ou cinco triagens, faço uma, uma entrevista, vejo quem está mais de acordo...

E10.22 - através da conversa a gente já começa a perceber se tem o perfil ou se não tem o perfil, se tem alguma experiência, então são alguns aspectos que a gente vai observando na entrevista $e$ dependendo de como for, a pessoa acaba iniciando na oficina.

E10.18 - pra oficina de culinária tem uma particularidade que tem que ter aí, cuidados de higiene, que tenha uma boa aparência, que tenha todos os dentes, que tenha uma aparência boa...

Para inserção em determinadas oficinas do NOT, algumas frases tais como as anteriormente citadas, evidenciam ainda a existência de outros critérios de acesso que são averiguados durante o momento da triagem:

E10.19 - por ser uma oficina de culinária, e a gente leva as pessoas pra evento, então tem que ter uma boa aparência.

E10.20 - Saber falar, também não precisa ser um garçom experiente, mas tem que ter uma pessoa, tem que ser uma pessoa que tem uma facilidade de trabalhar com público...

Por conseguinte, esse momento da entrada e recepção, triagem, definirá o acesso ou não do usuário ao serviço, a partir de uma investigação que decidirá se o usuário passará para a próxima etapa do processo de trabalho a ser realizado dentro do serviço ou se retornará ao serviço de referência para adequar-se aos critérios e posteriormente tentar conseguir o acesso.

Esta avaliação, que no caso do NOT é realizada durante a triagem, denominada de momento de decisão, dependerá dos critérios estabelecidos para considerar se o problema trazido pelo usuário é entendido como uma necessidade de saúde pertinente ao conceito utilizado pela instituição, 
problema este que poderá ou não ser objeto de ação conforme os critérios adotados pelo modelo de atenção do serviço (Merhy, 2002).

Este momento também reproduz o paradigma psiquiátrico que busca estabelecer desde o início uma relação de saber-poder com o usuário, na qual este último deverá submeter-se na condição de assistido.

O acesso ao serviço por vezes é negado ou obstaculizado por critérios subjetivos, como a avaliação pessoal que está atendendo e por critérios objetivos, como a inexistência do tipo de ação considerada adequada ou mesmo a falta de vagas (Merhy, 2002).

No NOT, o acesso dependerá também da disponibilidade de vagas nas oficinas escolhidas pelo usuário. $\mathrm{Na}$ inexistência de vaga na oficina pretendida, essa triagem será encaminhada para uma fila de espera e só será novamente ativada no surgimento de uma vaga, conforme referido pelos entrevistados:

E3.9 - num primeiro momento experimentar uma primeira opção dele ou na segunda opção dele, onde surgir vaga em primeiro lugar...

E2.12 - E ele pode fazer três escolhas, por ordem, então fica na lista de espera...

E2.13 - ... Normalmente fica na lista de espera e é chamado quando tem vaga.

E10.16 - a gente faz triagem, e a partir do momento que surge uma vaga na oficina, a gente vai lá na pasta de triagem, e vai por ordem dos mais antigos pros mais novos, e vê quais escolheram a oficina...

Como resultado, em alguns casos, o usuário, após um tempo indeterminado de espera, não tem mais interesse em participar da oficina ou não apresenta condições para tal. Essa situação foi relatada pelos fragmentos a seguir:

E2.14 - Normalmente a gente faz assim: pega alguns, que estão na lista de espera e chama, faz uma entrevista, então tem uns que estão na triagem, na espera, mas não querem mais.

E2.15 - Às vezes tem caso de óbito, às vezes chega aqui e não quer mais aquela oficina, ou às vezes chega aqui e a gente vê assim, por exemplo: pra oficina de nutrição tem que ter o mínimo de higiene, e às vezes a pessoa não tem dente, e aí a gente tem que redirecionar para outra oficina. 
E4.19 - depois, assim que surgir uma vaga na oficina a gente chama esse usuário, pra ter uma conversa inicial, pra saber se ele tem interesse ainda na oficina ou não.

No processo de triagem realizado pelos coordenadores das oficinas, um fator positivo relatado refere-se à possibilidade de escolha do usuário, após a visitação dos espaços das oficinas. $O$ usuário então poderá escolher mais de uma oficina, de acordo com seu interesse.

E6.10 (escolha da oficina) - Às vezes por afinidade pela atividade ou porque gostaram da oficina, assim, quando passaram por ela...

E6.9 - a inserção deles, antes dele ser inserido, ele passa por um processo de triagem, que depende de um encaminhamento do serviço que ele está sendo atendido, então agenda essa triagem e ele vem, escolhe, a gente explica o que são as oficinas, passa pra fazer uma visita e eles escolhem a que eles gostariam de participar...

E3.7 - Então nós fazemos uma visita pra ele conhecer as oficinas e se imaginar trabalhando em qual delas, que daria assim um primeiro norte a eles, da qual eles se sentiriam bem, e a partir daí então, a ficha dele será encaminhada para coordenadora da oficina.

E3.8 (inserção) - uma pasta que nós temos onde a gente arquiva por data de chegada, de triagem, de acordo com, assim, a oficina que ele escolheu, então a número um ou a número dois, no máximo duas opções...

Esse respeito ao desejo do usuário corrobora com a reformulação da assistência e da reabilitação psicossocial pelo trabalho, uma vez que não se trata de uma atividade prescrita ao usuário pelo operador, segundo sua classe social ou qualquer outro tipo de seleção, mas de um fazer que possibilite novos sentidos a começar pelo direito de escolha entre várias alternativas disponíveis.

E7.31 - Uma situação, acho, a gente pode ilustrar a partir do ponto que você recebe uma pessoa na oficina. Porque quando você recebe essa pessoa, você não sabe quem vem, ela vem a partir de um desejo que ela teve primeiro, porque ela passou por todas as oficinas e escolheu a oficina.

E1.46 - Então, às vezes vem gente que fala "Ah eu nunca fiz isso, mas eu quero muito aprender, porque meu sonho é... enfim, eu sempre quis foi ser pedreiro", aí ele vai ser incluído nesta oficina, tendo a vaga...

E1.61 - O critério de admissão que a gente mais usa é o desejo, quer dizer do querer trabalhar. Na experiência destes anos o que mais mostra é isso. Não é diagnóstico, não é aparência física, não é nada que subjetiva o que você consegue dizer que vai dar certo ou não, se a pessoa vai ou não ser incluída. É o desejo de querer 
participar, de querer trabalhar, de aprender, enfim, de estar em um grupo.

Em caso de não adaptação à atividade, após um período de experimentação, é permitido ao usuário a mudança de oficina, respeitando sempre seu desejo, sua necessidade bem como suas limitações ou dificuldades, conforme fragmentos abaixo:

E3.23 - por mais que você tente um grande período, às vezes não é aquela oficina que ele vai gostar de exercer seu trabalho.

E3.24 - Então nós trazemos pra reunião de equipe e discutimos uma outra chance, em outra oficina, e participamos a ele antes: qual você gostaria de ir?

E2.18 - Tem oficineiros que acabam trocando de oficina, às vezes não gosta, não consegue desenvolver algumas atividades, daí a gente conversa, tem reunião, troca...

Contudo, na análise do acesso evidenciamos um modo de estruturação do serviço que acaba por limitar a entrada dos usuários ao serviço, uma vez que este deverá se encaixar nos critérios da instituição, baseados não apenas no número limitado de vagas disponíveis, o que gera uma seleção dos mais qualificados, como também na lógica clínica que funda os serviços assistenciais. Portanto, encontramos algumas contradições neste aspecto, especialmente com relação à organização de novas propostas assistenciais que propõem, por exemplo, a substituição da triagem para um modo de recepção baseado no acolhimento.

O operador, no momento de encontro com o usuário, pode oferecer uma escuta mais ampla que possibilite a apreciação do sofrimento ou problema, a expressão dos desejos e necessidades, bem como o relato de sua história de vida pessoal e profissional, estabelecendo um primeiro vínculo positivo e construindo conjuntamente intervenções adequadas às suas necessidades. Essa maneira de recepção foi apontada por alguns entrevistados:

E1.83 - Aí a referência entra em contato falando do caso, do que é, do que não é, tem caso que vem e você tem que fazer todo um trabalho de acolhimento para que realmente venha, esta recepção tem que ser cuidada, então estas trocas é que são importantes, até pra vir e ficar, dependendo do caso.

E7.36 -Porque a gente procura assim, um sujeito que chega, esse sujeito tem, você tem que ter todo um jeito pra conhecer a história 
de vida dele, porque você não pode forçar pra um campo, você tem que conhecer pra você ver que campo você vai atuar, pra conhecer o sujeito e a história de vida dele enquanto pessoa, a historia de vida enquanto a doença, que serviço que ele está inserido, que expectativas que ele traz, que necessidades que ele traz.

E1.161 - Quando a gente pega essa ficha de triagem e chama esse usuário pra vir, então o primeiro momento é de entrevista que a gente vai estar se conhecendo melhor, de acolhimento, escuta da demanda dessa pessoa, o que ela quer, porque que ela vem, quem é esse sujeito e a gente se apresenta, então acho que um primeiro momento é um momento de troca, de conhecimento.

Esse modo de recepção estaria mais alinhado com a perspectiva de organização do processo de trabalho em saúde que se orienta com base nas necessidades trazidas pelo usuário e não somente pelo cardápio de ações ofertadas pelo serviço. Essa flexibilidade está presente nos discursos abaixo:

E7.35 - Eu acho que a situação é essa, a chegada de uma pessoa, e tudo que essa pessoa te abre enquanto leque de ações.

E7.37 - Então eu acho que a chegada é toda uma, você não sabe o que vão partir dali, o que vai acontecer.

Sendo assim, podemos concluir que o acesso, ou a entrada no serviço, resultante do encontro entre usuário e trabalhador, condiciona-se também à concepção individual deste último acerca do processo saúdedoença mental, da necessidade de saúde enquanto objeto de trabalho, do modelo de atenção, e ainda da sua visão particular sobre a missão institucional, ou seja, sobre a finalidade do processo de trabalho.

Tal fato constitui-se numa contradição, visto que ao mesmo tempo em que 0 acesso ficaria refém da subjetividade do trabalhador, mesmo utilizando-se de critérios objetivos definidos pelo serviço; por outro lado, possibilitaria a realização efetiva de um encontro e de uma negociação entre trabalhador e usuário, que somente ocorre quando do "exercício de autogoverno do trabalhador de saúde" no "espaço interseçor ${ }^{25}$ constituído na relação trabalhador/produtor e usuário/consumidor" (Merhy, 2002, p. 80),

\footnotetext{
${ }^{25}$ Conceito apresentado por Merhy (2002), inspirado na obra de Deleuze, Conversações, para designar o que se produz nas relações entre "sujeito", no espaço de suas interseções (intervenções) que é um produto que existe para os dois em ato, apenas existindo no momento da relação em processo, e na qual os inter se colocam como instituintes em busca de novos processos.
} 
questões que abordaremos mais adiante na análise da categoria processo de trabalho.

Outra contradição está evidenciada nos instrumentos de acesso, que combinam modelos referenciais antagônicos, como a triagem (interrogatório) e o acolhimento, o primeiro característico do modo asilar e o segundo do modo psicossocial.

\subsection{Adesão}

O processo de inserção no NOT, como vimos, é efetivado com o ingresso do usuário em alguma oficina de trabalho, após a passagem por alguns momentos de seleção: inserção e encaminhamento de algum serviço de atenção à saúde mental, agendamento da triagem, triagem e coleta de dados, visitação e escolha das oficinas, disponibilidade de vagas na oficina de escolha, entrevista com coordenador da oficina para averiguação de interesse e condições de ingresso. Contudo sua permanência na oficina ainda não está assegurada, como se depreende das frases abaixo:

E5.12 - Após a triagem os usuários escolhem as oficinas e são encaminhados para a mesma.

E2.16 - Então a gente sempre chama para uma entrevista e depois faz a adequação de tudo e explica como funciona e insere na oficina.

E6.11 - Aí a gente chama pra uma experiência, quando abre uma vaga na oficina...

E11.15 - ...quando eu vou chamar alguma pessoa para oficina de vitral, eu vejo a triagem pela escolha, pela primeira opção da triagem, eu chamo, essa pessoa por essa opção, pra uma primeira conversa, comigo, e depois comigo e o monitor.

O momento de introdução do usuário na oficina não segue um formato comum, mas caracteriza-se pela maneira de acolhimento ou recebimento estabelecido por cada oficina. Em geral, são os coordenadores ou os monitores quem fazem a apresentação do novo oficineiro para o grupo de trabalho e para a oficina em si durante as chamadas "rodas de conversa", quando esclarecem o funcionamento, as regras, a forma de remuneração, a organização do trabalho e definem o contrato (horário, freqüência) e o treinamento. Por sua vez, os oficineiros participantes são estimulados à 
receber o novo usuário, apresentando-se e esclarecendo também as regras, as técnicas e a rotina da oficina:

E6.12 - E aí quando chega lá ele é acolhido, tanto pelo coordenador quanto pelo monitor, que tem uma conversa inicial, assim, pra explicar como é que o funcionamento, como é que o cotidiano, e aí depois o monitor senta com ele e explica como que é a atividade, dá uma atividade inicial pra ele ir treinando, assim, e tem o acolhimento dos oficineiros também, que se apresentam pra aquela pessoa que está chegando e ajudam a ensinar a técnica...

E6.13 - sempre na roda, porque a gente faz roda toda semana, uma vez por semana. Aí sempre na roda eles explicam pra essa pessoa, qual que, porque que faz a roda, que é um momento de conversa, de trocas e apresenta a oficina também. Então, a inserção é feita dessa maneira.

E11.16 (processo de inserção) - Onde a gente explica como é o funcionamento da oficina, horário, o que ela vai realizar de inicio, como é o treinamento, se tem pagamento, se não tem, ou melhor, se tem bolsa, se não tem. Apresentamos assim, de maneira assim geral, o que é a oficina de vitral e suas, as suas regras...

E11.17 - Depois a gente faz uma apresentação pro grupo, pros outros oficineiros daquela pessoa, a gente faz uma apresentação.

Nesse momento também serão definidas as tarefas iniciais do oficineiro dentro do processo de produção da oficina, que, na maioria das vezes, começa com as atividades consideradas mais simples e de fácil execução:

E4.20 - ele começa, a partir daí ele vai ser inserido na oficina. Inicialmente, ele começa fazendo as tarefas mais básicas, mais fáceis...

E9.16 - a gente tem diversas funções, então a pessoa entra fica na função mais fácil que tem, e no único local, onde várias pessoas se reúnem ao mesmo tempo e ficam sentadas...

E10.46 - normalmente quem inicia na oficina e está como aprendiz, fica mais na parte da limpeza, então fica lá na pia, lavando a louça, passa um pano no chão, fica mais na parte de aprendiz.

Com a introdução do usuário na oficina de trabalho, inicia-se o período de adaptação e de treinamento, do qual participam tanto o coordenador e o monitor, como também os demais oficineiros, que orientam e ajudam nesse processo inicial. O desempenho apresentado pelo novo oficineiro durante esse período relacionado à capacidade de aprendizagem e de execução das tarefas e também à evolução de sua reabilitação psicossocial, também serão considerados critérios de permanência na oficina, segundo os fragmentos: 
E1.167 - aí começa o processo de observação do desempenho, o que realmente ele sabe fazer, às vezes ele fala ah, eu sou pedreiro, aí põe pra fazer uma parede, não vira nada, não consegue.

E9.14 (inserção e permanência) - Ele passa por um período de adaptação na oficina, e nesse período ele conhece melhor o local que ele escolheu, se ele tinha alguma fantasia, ou alguma coisa, ele pode já lidar com isso...

E9.15 - nesse período de adaptação, e a gente também começa a conhecer o usuário nesse tempo.

E11.22 - E depois o treinamento, eu acho que o treinamento é um critério pra ver se a pessoa vai se adequar naquela atividade, principal, ou não.

Durante o treinamento, portanto, o desempenho do usuário será avaliado pelo grupo, podendo ser experimentado em várias atividades dentro da oficina, como se depreende dos depoimentos a seguir:

E11.23 - Ela não conseguindo realizar aquilo, a gente vê uma outra atividade, dentro da oficina, pode ser a pintura, pode ser o rejunte ou a limpeza das peças, ela não conseguindo realizar.

E11.24 - Então o treinamento é onde a gente dá uma verificada nisso. Em último caso, se ela não se adéqua a nenhuma dessas atividades, porque não consegue realizar, porque tem dificuldade, é onde, a gente verifica se existe um outro espaço em outra oficina que aquela pessoa poderia estar contribuindo mais.

Outro critério de permanência apontado pelos entrevistados refere-se à capacidade individual do novo oficineiro em adaptar-se à organização do serviço e à produção na oficina, especialmente com relação à sua habilidade em desenvolver as técnicas utilizadas para execução das tarefas. Essa adaptação configurar-se-á num dos itens das avaliações de desempenho realizadas periodicamente, conforme as frases abaixo:

E3. 10 - a permanência desse usuário vai depender muito dele, da adaptação, de se observar a habilidade para aquela técnica do artesanato ou não.

E10.24 - normalmente a permanência depende do próprio usuário, do próprio oficineiro, da força de vontade, da freqüência, depende, eu acho que depende mais dele.

E11.25 - o critério de permanência na oficina, se a pessoa conseguiu se adequar a atividade, se está bem, ela continua...

E10.23 - E a permanência do usuário da oficina vai de acordo com o usuário, se ele está indo bem, se ele está freqüentando a oficina, se está tendo faltas, a gente vai fazendo uma avaliação também mensal, todo mês tem avaliação... 
A adaptação ao grupo de trabalho também é avaliado como um determinante da adesão do usuário na oficina, caracterizada, segundo os entrevistados, pelo estabelecimento de relações e vínculos positivos tanto com o coordenador e com o monitor, quanto com os demais oficineiros:

E3.14 - O convívio com os iguais, essa interação com o grupo é que vai demandar a sua permanência ou não.

E3.16 - e a partir do momento que eles se sentem entre os iguais e começa um relacionamento, o vínculo principalmente com monitor e coordenador, e com os colegas, com o grupo...

E7.51 - Tem pessoas que foram contratadas pelo Cândido, então a permanência depende da evolução e a não permanência depende também se ele não consegue nem adaptar a convivência, ou alguma técnica...

E3.11 - Então é uma questão aí, do coordenador ter a sensibilidade, ir avaliando passo a passo a sua adaptação ao grupo, à atividade, $e$ ao NOT em si...

Os fragmentos de textos, entretanto, evidenciam a preocupação constante dos coordenadores em promover a inclusão dos novos oficineiros no processo de produção das oficinas, utilizando para tal algumas estratégias como alteração das técnicas de execução de alguma atividade, mudança ou adaptação das atividades que favoreçam e estimulem a potencialidade do usuário, ou como último recurso, a mudança de oficina de trabalho, zelando sempre pelo respeito às necessidades, interesses e limitações dos usuários:

E7.46 (inserção e permanência) - Mas assim, se você vê que ele tem um potencial..

E7.48 - depende assim: se ele tiver outras oportunidades nas outras oficinas, da técnica que possa melhorar...

E6.38 - às vezes acabam não ficando, tem algumas desistências assim, ou se a pessoa tem muita dificuldade, a gente vê as outras oficinas que ela escolheu também, se às vezes ela se dá melhor.

E6.41 - E assim, a gente tenta adaptar também, quando uma pessoa tem muita dificuldade em uma coisa...

E7.33 - Então que você vai ta trabalhando é com o desejo do outro, seja da convivência, seja de ganhar dinheiro.

Para facilitar a adesão dos usuários tanto ao grupo quanto ao processo de trabalho da oficina, alguns entrevistados relatam outras estratégias que se alicerçam no apoio dos colegas para acompanhar e 
orientar o novo oficineiro durante esse momento inicial de inserção na oficina. Uma delas se refere à organização do trabalho numa bancada única que permitiria a troca de informações, o esclarecimento de dúvidas e a ajuda mútua entre os oficineiros durante a realização das tarefas:

\begin{abstract}
E9.21 - Quando a oficina era solta, sem a bancada onde cada um tinha o seu posto separado do outro, tinha muita dificuldade da pessoa permanecer na oficina depois que entrava, porque ele não estabelecia o elo tão rapidamente, se ele tivesse algum, qualquer dúvida, qualquer ponto que não fosse favorável, já era motivo pra ele desistir e sair.

E9.22 - Então essa bancada veio num momento interessante na vida da oficina, porque nela ficam agrupadas quatorze pessoas mais ou menos, quase a metade da oficina e os novos principalmente, então ele ficam ali limando peças...
\end{abstract}

Outro recurso relatado diz respeito à responsabilização de um oficineiro mais antigo pelo acompanhamento diário e contínuo do novo usuário, informando-lhe sobre a organização dos espaços, as regras, o contrato e o cotidiano da oficina. Esse recurso de adesão recebe o nome de apadrinhamento, conforme os fragmentos abaixo:

E9.23 - quando eles são introduzidos, eles têm um padrinho, alguém da oficina se dispõe a apadrinhar esse novo usuário e permanece próximo a ele durante algumas semanas, se for necessário. Mostra onde é o banheiro, leva pra almoçar, reforça alguns dados, que a gente já fez de um contrato, que já foi feito anteriormente, como horário de café, horário pra fumar, se for possível, e outras coisas mais da rotina da oficina.

E9.24 - E esse apadrinhamento também é muito importante, porque faz com que a pessoa se movimente com mais facilidade. Uma pessoa que não tem muitos recursos, de perguntar ou de levantar e procurar, ela tem uma pessoa com quem contar ali.

O conceito de adesão para a Organização Mundial da Saúde (OMS) refere-se a uma atividade conjunta e negociada entre o técnico de saúde e o usuário, que dependerá não apenas da aceitação, da motivação e perseverança do usuário quanto às orientações e recomendações do profissional, mas também do princípio de autonomia, que promove a informação e respeita a concordância do usuário quanto às mesmas, estimulando um papel mais ativo de ambos no estabelecimento de uma aliança terapêutica que responsabiliza a todos os envolvidos pelo sucesso e qualidade da adesão. 
A adesão, nessa concepção, é ainda caracterizada como um processo dinâmico e singular que sofre a influência de inúmeros fatores mutáveis, como as modificações no contexto de vida dos envolvidos, que por sua vez repercutem em suas necessidades e interesses. Portanto o serviço deve estar atento às singularidades e oferecer alternativas diversificadas para facilitar a adesão (Caraciolo, 2007).

Nesse sentido, os fragmentos apontam para essa concepção de adesão mais dinâmica e flexível:

E3.25 - Pra poder estar viabilizando uma outra tentativa, ou seja, esgotamos todas as possibilidades dentro do NOT, enquanto adequação das atividades.

E4.55 - as possibilidades são várias, são diversas, eu acho que, se a gente senta e vê o indivíduo, a necessidade dele, o que ele precisa, a gente consegue recolocá-lo em outra tarefa, adaptá-lo a alguma ferramenta, eu acho que a gente consegue dar continuidade ao trabalho sim, com alguns limites, com algumas dificuldades, mas não é impossível.

Destarte, podemos apontar a presença nos discursos da constante preocupação dos coordenadores do NOT quanto à adesão dos usuários nas oficinas, concebida não apenas como uma condição individual do usuário em seguir as determinações dos profissionais e adaptar-se à organização do serviço, como vimos anteriormente, mas também como uma intervenção cabível aos técnicos no sentido de considerar a singularidade dos usuários, respeitando suas diferenças e promovendo adaptações que favoreçam esta adesão.

E9.25 (bancada e apadrinhamento) - Então a gente percebeu que essas, esses dois fatores auxiliaram bastante na permanência do usuário quando ele entra na oficina. Então raras pessoas que desistem, e quando saem, saem geralmente é por outros motivos.

E3.15 - A sua maioria fica, então a adesão, eu diria que é 99\%.

Corroborando com essa concepção, o respeito às necessidades de cada usuário também é apontado como um fator importante para a adesão na oficina, segundo os fragmentos abaixo:

E6.19 - Então a permanência de cada um, depende assim, da evolução deles, qual que é o objetivo deles também pra vida, naquele momento...

E6.17 - E tem outras pessoas que passam por lá, não tem um tempo certo pra cada um. 
E7.49 - como tem uma diferença das bolsas porque depende do que as oficinas vão vender, porque tem oficinas que tem, são prestação de serviços, que os clientes são um pouco mais fixos, no artesanato é mais difícil, oscila, e o papel a gente ainda está tentando se organizar, reorganizar, vamos dizer assim. Então a permanência deles é, depende muito disso.

Esses mesmos fatores são levados em consideração no caso de desligamento ou mudança de oficina por solicitação do usuário, em geral, motivada pela necessidade de "ganhar mais" seja pelo ingresso no mercado de trabalho formal seja pela troca por outra oficina de trabalho cujo valor da bolsa-trabalho possa ser maior:

E8.51 - Então tem alguns casos graves assim, que a gente acaba desligando, quando a pessoa realmente não quer, não quer estar na oficina...

E2.19 - também têm uns que tem alta, tem uns que arrumam um emprego formal e acabam se desligando...

E11.36 (desligamento) - foram por pessoas, assim, mudaram de oficina, porque precisavam ganhar mais.

E11.37 - Algumas porque arrumaram emprego, em outros locais, registrado e tudo mais, algumas pessoas foram assim. Acho que são poucos, não existe um rodízio grande.

E11.38 - Algumas porque saíram por conta própria mesmo, não quiseram mais trabalhar na oficina. Agora, acho que é mais isso.

Mesmo assim, embora os discursos aparentem considerar a singularidade dos usuários, princípio fundamental da atenção psicossocial à transformação assistencial que anteriormente promovia a massificação dos doentes pela ausência de projetos terapêuticos individualizados, contraditoriamente as condições de acesso e de adesão às oficinas, bem como de desligamento refletem também uma concepção assistencial e reabilitadora que se dirige à normatividade social visto que propiciam a habilitação para o trabalho pela passagem seqüencial das etapas de aprendizagem técnica e pela re-educação às normas das relações de produção (função pedagógica do trabalho) que prepara os oficineiros para o mercado de trabalho formal, utilizando também o cumprimento das regras institucionais pré-estabelecidas, condição de permanência nas oficinas, como forma de re-socialização às regras sociais, como veremos na análise das próximas categorias. 


\subsection{Desligamento (Saída)}

As razões para o desligamento de algum oficineiro do NOT estão baseadas no descumprimento das regras definidas pela instituição e pelos grupos das oficinas. Como regra fundamental, os discursos referem a adesão e continuidade do tratamento, exigidas não somente como condição para o acesso mas para a permanência do oficineiro nas atividades do NOT:

E3.26 - A exclusão é muito rara, só mesmo o dependente químico quando não assume o tratamento concomitante à oficina, ou não cumpre as regras do trabalho. Mas é muito raro isso.

E2.17 (permanência) A permanência não tem um tempo estipulado, depende da adesão da pessoa na oficina, no tratamento médicoterapêutico que às vezes não acompanha e daí não dá conta de ficar, tem vários... É bem individual.

E10.27 - é um dos critérios. A gente cobra a ida ao CAPS ou centro de saúde, dependendo onde está fazendo tratamento, eu cobro sim.

E10.30 (tratamento como critério de inserção e permanência) - Têm outros que vão, vão porque gosta, porque sente necessidade, acha importante, mas têm outros que tem que pegar no pé sim pra ir.

E3.28 - não seguir o tratamento, é uma regra, ele precisa estar em tratamento...

Essa exigência de acompanhamento terapêutico parece se basear numa visão que condiciona a necessidade de estabilização do quadro psiquiátrico à participação em processos produtivos, uma vez que em situações de crise ou recaída, os usuários não conseguiriam produzir nem relacionar-se adequadamente. Esse mesmo argumento, entretanto, justificou a rotulação de incapacidade e periculosidade que se traduziu na exclusão do louco tanto da esfera produtiva quanto das relações sociais, que abordamos na revisão de literatura desta pesquisa.

E3.29 - Então para estar bem no NOT e estar em grupo, em atividade oito horas por dia, ele precisa seguir o tratamento.

E3.31 - Como que ele vai ficar no NOT sem um acompanhamento psicológico?

E3.35 - Aí chega um momento que, aí os limites, não está obedecendo os limites, aí sim que ele é excluído, quando não acompanha o que se planeja em PTI pra ele...

Por conseguinte, nos casos de abandono ou qualquer outra dificuldade de acesso ao tratamento, caberá aos técnicos a responsabilidade 
de conversar com o usuário e/ou informar a sua referência terapêutica ou o serviço de tratamento para discutir e assegurar a continuidade do acompanhamento no serviço de origem ou em outro serviço de escolha do usuário.

E6.32 - Se ele abandona, a gente vê porque que ele abandonou, tenta entrar em contato de novo com a referência pra ele retomar $o$ tratamento. Porque às vezes é um momento que ele passou, que ele não ficou legal e abandonou tudo...

E6.34 - É a gente conversa: porque que ele não quer esse tratamento, ou se aconteceu alguma coisa lá, se ele preferir ir pra um centro de saúde, não sei.

Se após todas essas tentativas de convencer o usuário a retomar 0 seu tratamento, este se negar a fazê-lo, essa recusa terá como conseqüência o seu desligamento da oficina, de acordo com os fragmentos abaixo:

E6.33 (tratamento e participação na oficina) - Então a gente ajuda nessa retomada, se for uma coisa que ele não quer mesmo, aí acaba desligando...

E6.36 - Mas se for uma coisa da pessoa mesmo, de não querer estar em tratamento, é que é difícil assim de acontecer. Aí em último caso faz o desligamento.

A obrigatoriedade do tratamento, como condição de participação nas oficinas de trabalho, nos remete à discussão sobre o modo de atenção psicossocial que se fundamenta na garantia dos direitos dos usuários em contraposição à atenção asilar. Na perspectiva de reformulação a questão da cidadania se tornou fundamental na transformação não apenas dos espaços assistenciais, como das relações de poder entre profissionais e usuários, que se fundamenta na ética da cidadania singularizada e da produção de subjetividade singularizada, conceituada no texto abaixo:

A meta da singularização só poderá ser almejada por uma concepção do 'objeto' e dos meios, e da relação dos dois, que seja capaz de atender à especificidade da subjetividade humana, e que inclua a própria ação e autodeterminação como constitutivas do homem. Ninguém trabalhará na subjetividade à revelia do sujeito, a não ser para a produção de efeitos de destituição subjetiva. Para ser almejada e alcançada, a singularização dependerá de que a forma das relações sociais e humanas na instituição parta da horizontalização como meta e, em alguma medida, seja vivida como exercício. Sem isto não há a menor plausibilidade em propor a implicação subjetiva e sociocultural do usuário e do trabalhador; sem estas parece-nos que não pode haver terapêutica na 
perspectiva da singularização (Costa - Rosa, Luzio e Yasui, 2001, p.22).

Nesse sentido, a cidadania não pode ser vista como um ideal subjetivo, mas como uma meta ética real, colocada em prática no cotidiano das intervenções assistenciais, especialmente na medida em que a instituição seja capaz de desconstruir seu papel repressivo e segregador na sua relação com os usuários e com a população do território, reconhecendo a necessidade de superação das relações de poder-saber e das práticas voltadas à adequação do indivíduo ao meio e do ego à realidade em direção ao desenvolvimento de espaços de interlocução para questões subjetivas e socioculturais cuja meta radical se dirige à implicação subjetiva, na relação do sujeito com o desejo (Costa - Rosa, Luzio e Yasui, 2001).

Nessa mesma perspectiva, as crises devem ser acolhidas não como descontinuidades ou rupturas, mas como efeitos estruturais e, portanto, também estruturantes, concebidas como integrantes do modo de o sujeito se posicionar em relação às conjunturas conflitivas (subjetivas e socioculturais) que os atravessam. Sendo assim, o modo psicossocial nega a finalidade de cura para retomar contato com o sujeito a partir de um cuidado que busca a transformação dos modos de viver, responsáveis pelo seu sofrimento.

Corroborando com essa concepção, em situações de agudização de sintomas graves, crise psicótica ou mesmo de recaída no consumo de álcool e outras drogas, quando o usuário já está inserido na oficina de trabalho, a atuação dos coordenadores é mais tolerante e acolhedora. De acordo com os relatos, em alguns casos, tenta-se manejar a situação dentro da oficina:

E11.28 - E mesmo tem pessoas que estão em crise, que não estão legal e a gente consegue manter dentro da oficina também. Não necessariamente assim: ah está em crise, não dá pra ficar.

E11.29 - Muitas vezes a gente prefere que fique dentro da oficina até mesmo em crise, porque muitas vezes aquela pessoa não quer leito-noite, não quer uma internação, então a gente tenta lidar, com ela em crise dentro da oficina e com o local de atendimento, mantém um contato constante.

E1.71 - Em crise, aí depende, tem paciente que consegue ficar, têm alguns que não. Daí depende do tipo da crise.

E1.76 - Têm alguns que entram em crise, mas a gente consegue lidar com o CAPS, às vezes se certifica que precisa tomar a medicação, porque deixou, certifica que está tomando aqui, o 
pessoal pede ajuda, dá para vocês darem a medicação, o monitor ou o auxiliar de enfermagem, e aí ele nem precisa ficar afastado, consegue ficar. Um pouquinho persecutório, mas consegue lidar, consegue continuar.

Nesses casos, como referido pela frase anteriormente citada, caberá ao coordenador e/ou a equipe técnica do NOT avaliar e, se necessário, juntamente com o serviço de referencia, decidir sobre a possibilidade de manejo da situação dentro da oficina, respeitando a necessidade de acompanhamento do usuário em crise e também zelando pela sua segurança e continuidade da produção.

E8.54 (avaliação de afastamento) - O próprio coordenador da oficina. Se é uma discussão que a gente acha que merece uma discussão mais ampla, com serviço de origem, um CAPS, um centro de saúde, a gente faz essa discussão ampliada e avalia juntos, toma decisões juntos. Mas geralmente é coordenador da oficina que identifica, avalia, propõe, ou acolhe a sugestão do próprio oficineiro.

E1.73 - Agora se ele já está na oficina e tem uma crise, pode ser que ele fique pode ser que não, aí é de cada caso. Se não der pra ficar, a gente encaminha pro CAPS. Encaminha assim: naquele dia ou naquele período, hoje, por exemplo, a gente teve que levar lá no CAPS Novo Tempo, porque ele veio com crise de mania, assim super-acelerado, aí não tem condição de ficar, portanto aí a gente leva pro CAPS.

E1.78 - Quando consegue lidar com a crise na Oficina, quando, às vezes, é uma situação que mexeu em casa, que continua vindo. Cada caso é um caso, tem caso que vai rápido, que nem sai da oficina, tem outros que a gente tenta continuar na oficina, mas aí chega no limite e a gente diz - ah não dá prá ficar - e aí sai.

E1.79 - Só quando não dá mesmo, ou ele está se colocando em risco, esses dias teve um que estava em crise querendo achar que ele podia parar a máquina lá na serralheria com o dedo, querendo mexer em coisas que ele não podia, que ele nem sabia mexer, aí tem que ficar alguém do lado o tempo inteiro, daí já não dá. Afasta por um tempo, a gente diz ó é melhor você se tratar, se afasta por um tempo... aí depende da relação que ele tem com o trabalho.

Entretanto, na avaliação de um sujeito entrevistado, o fato de algumas oficinas funcionarem no espaço assistencial do SSCF, acarreta uma maior valorização dos sintomas psicopatológicos, uma vez que o espaço de trabalho é também um espaço de tratamento, modificando também 0 comportamento do oficineiro e o encaminhamento da situação:

E8.46 (diferença entre os espaços) - Ficou nítido, e mesmo as intercorrências, a gente vê que lá, é uma avaliação minha essa, eu observo que tem uma valorização de uma alguma intercorrência, porque lá tem o médico, tem enfermeira, tem o auxiliar, tem a 
equipe do NAC, que é da internação que está lá, então quando ocorre alguma intercorrência parece que tem uma valorização daquele caso, daquela situação.

E8.47 - Aqui tem intercorrências também, mas o encaminhamento é outro, porque não tem um médico, não tem enfermeira, não tem alguém para dar uma assistência assim, e a gente vai observando, os sintomas, o que ele está trazendo, a gente faz o devido encaminhamento, é tranqüilo, tem dado certo...

E8.48 (diferença entre os espaços) - porque aqui é o espaço de trabalho; lá é trabalho e assistência.

De maneira geral, segundo os entrevistados, quando ocorre uma intercorrência dessa natureza, o usuário é afastado da oficina temporariamente para intensificar o tratamento, conforme sua necessidade, podendo regressar ao serviço quando estiver melhor, sem prejuízos com relação à sua vaga na oficina ou em qualquer outra de sua escolha. Em alguns casos esse afastamento é negociado com o usuário como um período de férias, garantindo uma continuidade na vida do sujeito:

E1.74 - Então, ele não é desligado da oficina por conta da crise. Este paciente de hoje, o X, ele foi pro CAPS, provavelmente daqui a uns dez dias ele volta para a oficina tranqüilo.

E1.75 - Geralmente assume a mesma função, volta na mesma condição. Às vezes, fica em alguma observação, mais próximo do monitor, depende. Mas, normalmente volta para a mesma função, estes casos de uma crise passageira assim.

E8.52 - ou quando a gente avalia que ele entrou numa crise, mais longa, e a gente avalia que a oficina não vai dar conta de cuidar dele, acolher ele naquele momento da crise, e ali não é bem uma alta que a gente dá, desligamento, mas é um período que ele fica afastado da oficina, isso é conversado, contratado, e quando ele tiver melhor ele volta, a vaga permanece. Mas não é um desligamento é um afastamento.

E8.53 - É bem pequeno que ocorre esses afastamentos, não é muito assim, esse índice de afastamento. A gente acaba lidando na própria oficina, às vezes um ou dois dias ele não vem pra oficina, pra ficar mais intensificamente no CAPS, ou às vezes ele pede férias porque ele não está dando conta de ficar na oficina, e a gente vai avaliando, é caso por caso, e em seguida ele volta.

E1.80 - Tem uns que não querem faltar, aí você fala: "Não, você tem direito a tirar férias". Então tira férias. Sai ali sempre um contrato, em momentos de crise, para dar conta disso.

Nos casos dos usuários de álcool e outras drogas, contudo, as crises, comumente chamadas de recaídas, não são vistas com tanta tolerância pelos entrevistados. O uso ou porte de alguma droga ou ainda o fato de 
apresentar-se intoxicado no espaço da oficina é considerado um rompimento de regras que, se repetido, resultará em desligamento do oficineiro:

E6.29 (portar drogas) - Então se ela continua, a gente conversa uma vez, dá uma advertência, mas se ela continua fazendo isso a gente acaba desligando. Quando tem muito desrespeito também dentro da oficina, com os colegas, então nesse caso a gente desliga.

E10.26 (desligamento) - o último que eu desliguei, alcoolista, ele teve recaída, ficou internado, voltou, a gente recontratou: olha vamos começar de novo, tentar se esforçar. Teve uma nova recaída, na terceira vez, a gente combinou: se tiver de novo, abandonou de novo a oficina porque daí fica vários dias sem vir, vai ter o desligamento, então esse foi um caso que aconteceu.

E4.48 - Agora se traz uma droga, vamos supor, e eu pego, entendeu, alguma coisa, daí vai ser desligado porque ele está rompendo com a regra.

E6.27 - Por exemplo, pra dependentes químicos, a gente sempre faz o combinado de não vir alcoolizado ou feito uso de drogas pra oficina, ou trazer substâncias pra cá.

E4.36 (desligamento) - Existem as regras da oficina de permanência, que é não vir alcoolizado, não trazer álcool nem drogas pra dentro da oficina, manter um convívio com todos adequado. Então assim, existem algumas regras que eles quebram, que daí é motivo pra ser desligado da oficina.

Nos casos de intoxicação por consumo de álcool e outras drogas, não é permitida a permanência do usuário na oficina. Este será encaminhado para desintoxicação em algum serviço de saúde, podendo ou não retornar à oficina, a depender do comprometimento decorrente do uso de substâncias psicoativas:

E1.69 - Alcoolizado ele pode até vir, mas não trabalha.

E1.70 - O intoxicado não, já é do contrato. Para esta população já faz parte do contrato. Se vier alcoolizado ou sob efeito de alguma substância, não pode trabalhar.

E1.173 - Essa primeira apresentação do grupo e da oficina, a gente já coloca as regras, uma delas é não vai trabalhar alcoolizado.

E3.33 (intoxicado na oficina) - Vai pro CAPS. Ele não trabalha nesse dia porque ele está inadequado pra estar participando do grupo. Está sem nenhuma condição, então ele vai pro CAPS.

E6.28 - Então se a pessoa vem alcoolizada, ou feito uso de drogas a gente faz encaminhamento pro pronto socorro, pro serviço, pra ela desintoxicar, mas ela não permanece na oficina. E se traz pra cá, a substância, aí já é mais grave também... 
O manejo dos casos de consumo de álcool e outras drogas em situação de recaída, entretanto, aparenta depender do grau de tolerância do entrevistado com relação ao uso de substâncias psicoativas. Os discursos evidenciam um tratamento diferenciado para as situações de crise psicótica e as de recaída. Estas últimas aparentam estar associadas à escolha do usuário em se recuperar, enquanto que, nos casos de crise psicótica, segundo a visão dos entrevistados, o usuário não teria essa mesma opção.

E3.34 (intoxicado na oficina) - não é desligado, é sempre oportunidade da oportunidade da oportunidade.

E9.27 - A maioria são por este tipo de motivo, de crise ou recaída. Mas em crise psicótica, muito difícil, mais da parte do alcoolismo e droga.

E9.32 - E pode ver que cada caso é um caso, existe uma probabilidade, de às vezes o usuário ele também não quer se recuperar, isso vai muito dele, então nesse caso seria os alcoolistas e usuários de drogas e substâncias, porque os psicóticos já não têm essa opção assim, não tem essa abertura então.

E8.50 - E a gente até entende, estou falando mais agora do caso álcool e drogas, mas a gente entende que a recaída é um pedido de ajuda, quando ele chega recaído aqui pra gente, mas também tem os limites, tem que ver até onde ele quer ser ajudado.

A questão da vontade dos usuários de álcool e drogas, referida pelos fragmentos acima, nos remete à discussão entre vontade e razão apresentada pelos estudos de Foucault que se referem ao poder psiquiátrico introduzido pela terapêutica dos alienistas na qual a vontade estaria relacionada um fenômeno moral e não intelectual (Barros, 2001). Ao psiquiatra caberia o exercício de uma relação de poder capaz de submeter o louco à verdade e à razão no sentido da aceitação da doença e da reeducação moral de suas vontades e suas idéias, como afirmado por Pinel numa entrevista estudada por Foucault:

A terapêutica da loucura é a arte de subjugar e de dominar, por assim dizer, ao alienado, pondo-o em estreita dependência de um homem que, por suas qualidades físicas e morais, está apto para exercer sobre ele um domínio irresistível e é capaz de trocar a cadeia viciosa de suas idéias(apud Canoni, 2009, p.100).

Esse conceito foi desenvolvido por Esquirol, concebendo a necessidade do isolamento no tratamento da loucura a partir de 5 razões, que na essência tratavam-se de mecanismos de controle e submissão 
baseados na moralização dos comportamentos desviantes do louco, como enunciado abaixo:

(1) assegurar a segurança pessoal e da família; (2) libertá-los das influências exteriores; (3) vencer suas resistências pessoais; (4) submetê-los a um regime médico; (5) Ihes impor novos hábitos intelectuais e morais. Vê-se claramente que se trata de uma questão de poder, medir o poder do louco, neutralizar os poderes exteriores, estabelecer sobre ele um poder terapêutico e de moralização (Foucault apud Canoni, 2009, p.100).

Dessa maneira, a loucura depois de Esquirol e Pinel, antes inscrita sob o eixo "verdade-engano-consciência", passou a inscrever-se sob o eixo "paixão-vontade-liberdade". A instituição psiquiátrica foi eleita como lugar onde a vontade perturbada, as condutas indesejadas, as paixões pervertidas do louco se defrontará com a retidão da moralidade socialmente esperada. Entre vontade e terapêutica se estabeleceu desde então um processo de oposição, de luta, de dominação, conforme afirmação de Esquirol: "é necessário aplicar um método perturbador, é necessário subjugar o caráter inteiro de certos doentes, vencer suas pretensões, dominar seu orgulho" (Foucault apud Canoni, 2009, p. 101).

Essa concepção alienista do processo de saúde-doença como anormalidade orientou as técnicas e procedimentos das instituições asilares, entretanto, mesmo com a transformação dos espaços físicos manicomiais, os novos serviços não estão isentos de reproduzir essa terapêutica moralizadora pela manutenção de instrumentos como o interrogatório e a medicalização, que prescindindo do isolamento, mantém a função de docilização e domínio das paixões, dos delírios e maus hábitos produzindo um novo tipo de isolamento químico pelo uso de psicofármacos, que modelando os comportamentos e dominando pensamentos, reduzem o risco da violência e reproduzem estruturas de saber-poder em roupagens mais modernas (Canoni, 2009).

Essa permanência de elementos manicomiais mesmo após o processo de reformulação da assistência foi mencionada por um dos sujeitos entrevistados ao distinguir os espaços das oficinas de trabalho do NOT e a visão dos oficineiros sobre essas diferenças:

E8.43 - Têm muitos aqui que nem chegaram a passar por esse período, por essa fase, antes da reforma psiquiátrica, mas 
vivenciaram em outros hospitais, de serem trancados, super medicados, por uma violência.

E8.44 - E eles têm trauma e eles enxergam ainda o Candido como esse espaço, embora mudou muito os espaços, principalmente o modo de tratar, de ver as pessoas, mas eles não aceitam, porque tem essa cultura, tem o espaço, os prédios estão lá construídos, as coisas não mudaram totalmente.

Analisando os discursos referidos aos usuários de álcool e outras drogas, identificamos a presença dessa concepção moral e a necessidade de intervenções mais adequadas à adesão dessa população, que sofre de diversas formas de preconceitos e de rejeição, uma vez que, em geral, são mais resistentes à subordinação pelas regras e disciplinas institucionais.

E3.32 - Os dependentes químicos, por exemplo, são os mais difíceis nesses aspectos. Então, aderem ao tratamento, ao trabalho, ao projeto NOT, mas não aderem ao tratamento? Quer dizer, precisa estar seguindo os CAPS AD e fazendo o acompanhamento lá também.

E1.183 - Só usuário de drogas eu acho mais difícil que quando é alcoolista, não sei, não dá pra dizer. É difícil você dizer: é mais difícil de você lidar com as questões de crise deles, do dia a dia, de recaída, isso é muito mais freqüente. Mas quando eles estão bem a produção é muito maior. Ao passo que a população de psicóticos assim, eles são mais assíduos, é mais tranqüilo isso, porém a capacidade pragmática é menor, está mais prejudicada, então tem essas diferenças aí.

E1.184 - pra atividade é interessante porque tem a capacidade produtiva do alcoolista e que daí eu acho que o psicótico se espelha aí e tenta ver o que, mostra o que ele pode estar fazendo.

E1.185 - É mais difícil lidar com os alcoolistas e trabalhar com essa questão da solidariedade, das diferenças, então tem uma dificuldade, que é o nosso trabalho de lidar com isso.

De acordo com a política atual do Ministério da Saúde para a atenção integral a usuários de álcool e outras drogas (2004, p.24):

O uso de álcool e outras drogas, por se tratar de um tema transversal a outras áreas da saúde, da justiça, da educação, social e de desenvolvimento, requer uma intensa capilaridade para a execução de uma política integral ao consumidor de álcool e outras drogas.

Nesse sentido, o mesmo documento assinala a necessidade de elaboração de ações intersetoriais e intrasetoriais mais condizentes à especificidade dessa assistência (vulnerabilidade, fatores de risco e proteção, estigmatização, ilicitude do uso), considerando a singularidade e a 
necessidade desse usuário, no sentido de favorecer, consequentemente, a equidade de seu acesso e sua adesão aos serviços de prevenção, de tratamento ou de reabilitação. Essa especificidade está presente nos fragmentos abaixo:

E9.28 - o alcoolista, em geral, acho que ele é mais inquieto. Acho que ele tem mais dificuldade de parar no lugar, de se estabelecer, muitos vêm da rua, como morador de rua, então pra eles pararem num lugar, sabe, criar raízes, não é uma coisa tão rápida.

E9.30 (alcoolistas) - Tem vários outros fatores que também envolve, a parte financeira, quando eles vêm pra cá, eles ficam num albergue, esse moradores de rua, do albergue eles vão pra uma pensão, às vezes eles não se adaptam a esse local, nem a vida dentro de uma pensão, e nem a própria pensão. Então um muda e depois vai morar com não sei quem, então tem uma série de fatores.

E9.31 (alcoolistas) - E eles vêm assim com muita demanda clínica também, de problema de hipertensão, problema dentário, problemas de outras doenças que ele possa ter. Então esse tratamento, essas saídas constantes pra se tratar, às vezes acabam até afastando o usuário da oficina também, impedindo que o vínculo seja tão forte.

E1.182 - E principalmente pra essa população, que é dependente, alcoolista, dependente químico, tem uma coisa assim do dia de hoje, então eles costumam às vezes trabalhar em obras, aí trabalha e recebe o dia, no outro dia bebe, então tem um circulo vicioso, acho que isso é uma dificuldade.

Além do uso, porte, ou intoxicação por substâncias psicoativas, e também do desrespeito ao grupo, anteriormente citados, são consideradas situações, quando não associadas ao sofrimento mental, que resultam em desligamento: o abandono sem comunicação; o descumprimento do contrato; o furto, roubo ou tráfico; e a agressão verbal ou física. Todas essas condições são consideradas regras institucionais que devem ser respeitadas:

E10.25 - E o desligamento da oficina, da nossa parte, depende de um não cumprimento de um contrato, de um desrespeito ou abandono, daí seria um desligamento da parte, da minha parte, eu desligar alguém, aí seria um desses motivos.

E1.68 - Desligar a gente só desliga se a pessoa descumprir alguma regra muito grave, por exemplo, um alcoolista vir alcoolizado e agredir alguém.

E8.49 (desligamento) - Só se for de uma falta muito grave, sabe? Por exemplo: um roubo, tráfico, é... quando a pessoa está usando abusivamente álcool e drogas no espaço, desrespeitando, burlando 
todas as regras, não cumprindo com os contratos, porque são várias tentativas...

E4.40 - pra ser desligado é rompimento da regras, se tem alguma briga, alguma agressão física, trazer drogas pra dentro da instituição, aí é motivo pra desligamento também.

As contradições apontadas na análise do modo de estruturação do serviço refletem a conjunção de contradições presentes na organização social, que se caracteriza por um processo de luta e conflito entre interesses. Nessa conjuntura conflitiva particular, a concepção de saúde mental pressupõe um posicionamento subjetivo e sociocultural dos indivíduos, que passa necessariamente pela conscientização das condições estruturais que conformam a luta de classes na sociedade e do papel das suas instituições, em particular, o modo de estruturação dos serviços de saúde (Costa-Rosa, Luzio e Yasui, 2001).

O modo de estruturação, por sua vez, fundamenta-se no modelo tecno-assistencial que no campo da reforma psiquiátrica identifica-se com o modo psicossocial em contraposição ao modo asilar, o que pressupõe uma transformação radical que, como vimos, deve ser colocada em prática cotidianamente pelos trabalhadores em todos os momentos do processos de trabalho em saúde, especialmente na etapa de recepção do usuário.

Para isso será necessário que tais agentes sejam capazes de rever, de forma drástica, sua representação da sintaxe e da semântica em termos lingüísticos e em termos dos conjuntos do arquitetônico e do mobiliário; abrir acesso aos usuários e da população do território a todos os espaços institucionais; criar modelos de recepção e de escuta das primeiras demandas, que sejam capazes de derrogar os atuais balcões e filas de espera, construindo uma relação direta que permita à instituição situar- se no imaginário e no simbólico como 'sujeito-suposto-saber', ou seja, que the permita funcionar como primeiro interlocutor e até como terapeuta, se for o caso, ali onde a instituição está acostumada a pensar e agir apenas como 'natureza morta' ou, na melhor das hipóteses, como suporte das relações sociais da sua produção ali atualizadas (Costa-Rosa, Luzio, Yasui, 2001, p. 22). 


\section{PROCESSO DE TRABALHO EM SAÚDE}

A análise da categoria processo de trabalho em saúde, como apontando anteriormente, está fundamentada teoricamente na concepção marxista sobre a centralidade do trabalho humano e na sua derivação metodológica sobre o modo de produção na sociedade, em particular, sobre o modo de produzir saúde numa determinada instituição.

Considerando a complexidade e relevância da categoria trabalho no desenvolvimento da história da humanidade, na evolução das condições materiais e intelectuais necessárias à produção e reprodução da vida, na constituição dos aspectos que configuram a organização social de cada época, e, por conseguinte, na sua influência e repercussão na formação da consciência social, na identidade e na vida concreta dos trabalhadores, nos limitaremos a apresentar nesta pesquisa algumas aproximações com os conceitos básicos da teoria marxista sobre o trabalho humano, essenciais à nossa análise.

É vasta a literatura científica que aborda a teoria marxista sobre o tema trabalho e suas diferentes expressões, e por essa razão vamos nos ater à utilização de alguns conceitos que definem a concepção do processo de trabalho em saúde, apresentada por autores que, por sua vez, fundamentam-se na concepção marxista acerca do processo de trabalho.

Em sua obra clássica O Capital, Marx (s/d, p. 202) afirma:

Antes de tudo, o trabalho é um processo de que participam o homem e a natureza, processo em que o ser humano com sua própria ação, impulsiona, regula e controla seu intercâmbio material com a natureza. Defronta-se com a natureza como uma de suas forças. Põe em movimento as forças naturais de seu corpo, braços e pernas, cabeça e mãos, a fim de apropriar-se dos recursos da natureza, imprimindo-Ihes forma útil à vida humana. Atuando assim sobre a natureza externa e modificando-a, ao mesmo tempo modifica sua própria natureza.

Marx definiu o trabalho como ato especificamente humano diferenciando do ato instintivo dos animais pela capacidade teleológica do ser humano em elaborar o objeto (projeto) em seu cérebro antes de objetiválo (execução). Em sua concepção sobre o processo de trabalho, como algo especificamente humano, identifica como seus elementos constituintes: uma 
vontade orientada a um fim, um objeto e os meios de transformação desse projeto num produto.

Em síntese, o processo de trabalho pode ser definido como um sistema de forças naturais dominadas que funciona como intermediário entre o homem e a natureza, como intermediário na diferenciação do homem como ser natural, dotado de carecimentos e poderes. O que determina 0 homem enquanto um ser natural é o fato dele apresentar necessidades que deverão ser satisfeitas por meio da utilização de suas forças na transformação da natureza em valores de uso, ou seja, por meio da produção de bens capazes (úteis) de satisfazer tais necessidades (Gonçalves, 1992).

A maneira de "fabricar" respostas a essas necessidades, na concepção dos marxistas, o modo de produção, por sua vez, determinou a forma de organização dos seres humanos em cada sociedade. Tanto as necessidades humanas quanto as condições (poderes) de satisfazê-las por meio do trabalho humano, não se constituem em fenômenos "naturais". Ambos, necessidades e poderes, definem o ser humano como ser natural sócio-histórico, cuja reprodução é resultante de condições materiais e históricas por ele mesmo produzidas em certo período e numa certa sociedade. Não existem, portanto, nem necessidade "natural" nem trabalho "natural", mas necessidade e trabalho socialmente produzidos e historicamente determinados.

Em função de sua característica de ser social, o homem vive, existe, trabalha, se produz e reproduz, somente organizado em grupos de homens, somente através de relações entre si. Essas relações não são apenas subjetivas, mas se objetivam em relações com os objetos e os instrumentos de trabalho durante o processo de trabalho, cujo término deve ter como resultado ao mesmo tempo: "produtos, re-produção ampliada das forças naturais dominadas, reprodução das relações sociais referidas aos objetos e aos instrumentos e, dentro e através disso tudo, re-produção dos próprios indivíduos-trabalhadores" (Gonçalves, 1992, p. 15).

Atualmente, costuma-se associar o trabalho humano à sua expressão particular no modo de produção capitalista: o trabalho assalariado. 
Entretanto esta expressão particular de trabalho, naturalizada pela ideologia capitalista, não constitui a essência desse fenômeno tão primitivo quanto o homem.

Já vimos que o trabalho configura-se como elemento central não apenas da organização social, mas dos elementos que a compõem e a constroem historicamente: os trabalhadores. A transformação do trabalho ao longo da história humana, das chamadas forças produtivas, dos modos de produção, dos processos de trabalho, portanto, configura-se como um elemento importante da análise dos modos de produzir numa determinada sociedade (dimensão estrutural) e também numa determinada instituição (dimensão particular), no caso desta pesquisa, num determinado serviço de saúde.

Como abordamos na apresentação da metodologia, para o pensamento marxiano, o princípio da totalidade apóia-se na afirmação de que só é possível compreender a parte conhecendo o todo com os quais estabelece conexões, e conhecer o todo implica em analisar as partes que o compõe e que determinam à realidade objetiva, concebida como uma totalidade dinâmica determinada materialmente.

Para compreender, portanto, a relação dialética entre a aparência, manifesta no fenômeno, e a essência, totalidade da coisa, da utilização do trabalho na experiência das oficinas do NOT, constatamos, durante a tematização dos discursos, a necessidade de analisar o processo de trabalho desse serviço, que se expressa, neste caso, de duas maneiras integradas: processo de trabalho em saúde do NOT e processo de produção de mercadorias das oficinas de trabalho, que trataremos mais adiante.

Utilizando como recurso a análise dos discursos dos entrevistados sobre da organização do trabalho tanto no NOT quanto nas oficinas, buscamos compreender o sentido do trabalho nesta experiência particular, para finalmente problematizar e contribuir com a discussão das propostas de reabilitação psicossocial no eixo trabalho fundamental ao processo de reformulação da assistência à saúde mental orientada pela desinstitucionalização e emancipação das pessoas com sofrimento mental. 
Sendo assim, para introduzir a análise desta categoria no universo particular do NOT, vamos lembrar que os elementos que compõem qualquer processo de trabalho na concepção marxista são: a atividade adequada a um fim, isto é, o próprio trabalho; a matéria a que se aplica o trabalho, o objeto de trabalho; e os meios de trabalho, o instrumental de trabalho.

No processo de trabalho, a atividade do homem opera uma transformação, subordinada a um determinado fim, no objeto sobre que atua por meio do instrumental de trabalho. $O$ processo extingue-se ao concluir-se o produto (Marx, s/d, p. 205).

O produto resultante desse processo, produto do trabalho, é um valor de uso, um material da natureza que foi adaptado às necessidades humanas por meio dessa transformação, desse trabalho, que por sua vez ficará incorporado ao produto.

Nesse processo de trabalho, considerando o seu resultado, meio e objeto de trabalho tornam-se assim meios de produção e o trabalho é trabalho produtivo $^{26}$ que também pode se tornar trabalho vivo, ao se apoderar da natureza e operar uma transformação de possíveis valores de uso em valores de uso reais e efetivos, cuja finalidade é serem utilizados pelo homem na satisfação de suas necessidades.

Outra característica importante do processo de trabalho é o fato de se tratar de um processo de consumo: o trabalho gasta seus elementos naturais, seu objeto e seus meios. No modo de produção capitalista, consome-se também outro elemento fundamental ao processo de trabalho: a força de trabalho, composta pelos trabalhadores que para sobreviver vendem sua força de trabalho ao capitalista na forma de mercadoria (Marx, $s / d)$.

Neste caso em que o capitalista compra a força de trabalho, o processo de trabalho caracteriza-se pelo consumo da mercadoria que comprou - a força de trabalho -, adicionando-lhe meios de produção, e por conseqüência, o resultado desse processo, o produto (valor de uso) é de propriedade do capitalista e não do produtor imediato, o trabalhador. A este último, o capitalista paga o valor diário da força de trabalho, que lhe pertence

${ }^{26} \mathrm{O}$ termo trabalho produtivo será posteriormente desenvolvido por Marx para associá-lo apenas ao trabalho assalariado que produz mais valia na relação com o capitalista. $A$ definição de trabalho produtivo está no Capítulo 6 inédito de $O$ Capital publicado separado. 
durante a toda a jornada de trabalho como outra mercadoria qualquer (Marx, $\mathrm{s} / \mathrm{d})$.

O consumo da força de trabalho no processo de produção capitalista durante a jornada inteira, entretanto, não corresponde exatamente ao valor diário da força de trabalho pago pelo capitalista, que the custa apenas o correspondente a uma parte do valor que ele é capaz de produzir em uma jornada. Ou seja, o capitalista utiliza-se de uma jornada inteira da força de trabalho, pagando apenas parte do seu valor. O tempo de trabalho excedente, ou trabalho excedente, que não é pago, é apropriado pelo capitalista como mais valia.

Esse processo de produzir mais valia distingue-se, portanto, do processo de trabalho, ou processo de produção de valores de uso, pelo fato do primeiro se prolongar além do tempo necessário à produção de valores de uso. São, portanto, duas formas distintas do processo de produção, que na verdade, se podem se apresentar na realidade de três maneiras: produção de valores de uso, produção de mercadorias e produção de mercadorias na forma capitalista, ou seja, produção de mais valia.

O processo de produção, quando unidade do processo de trabalho e do processo de produzir valor, é processo de produção de mercadoria; quando unidade do processo de trabalho e do processo de produzir mais valia, é processo capitalista de produção, forma capitalista da produção de mercadorias. (Marx, s/d, p. 222).

O trabalho em saúde nas sociedades capitalistas se reorganizou e desenvolveu como forma de controle de doenças em escala social, como forma de recuperação da força de trabalho na mesma escala e como forma de ampliação de direitos e de consumo das classes subalternas. Essas formas de articulação social do trabalho em saúde, dentro do processo de trabalho, passam a significar as necessidades, a que deve responder (Gonçalves, 1992).

Segundo essa formulação, mesmo relacionadas à saúde humana, as necessidades humanas não podem ser entendidas como "naturais":

...tudo que vier a constituir-se em necessidade de saúde humana passará por esse conjunto de determinações genético-estruturais dentro do qual o homem vem a ser humano, isto é, indivíduo sóciohistórico em sua individualidade, sendo mais importante, mas não a única dessas determinações, a objetualização em processos de trabalho (Gonçalves, 1992, p.25). 
Por conseguinte, nem os processos de trabalho e seus elementos constituintes - objeto, meio, agentes sociais - são "naturais", estes serão sempre humanamente naturais, isto é, social e historicamente determinados. Com relação aos trabalhadores em saúde, dentro de uma divisão de trabalho, nem mesmo essa existência pode ser entendida como natural, entretanto, na forma contemporânea de processo de trabalho em saúde, essas determinações sócio-históricas são negadas (alienação) tanto pela consciência atuante tanto dos trabalhadores quanto dos usuários, conforme texto abaixo:

\begin{abstract}
...para além de consciências objetivamente inadequadas, consciências alienadas, essas formas de consciência importam como finalidade do processo de trabalho, por um lado, porque então compreendê-las significa compreender as bases objetivas da alienação, e como auto-consciência dos sujeitos sócio-históricos específicos que se constituem em sua relação não exclusiva com esses processos de trabalho, porque então se pode compreender as conexões entre um campo específico de práticas e a reprodução social, e identificar aí, simultaneamente, as necessidades radicais e os processos de trabalho que tendem à sua objetualização. Neste sentido, pode-se então ousar pretender construir um projeto específico de práxis (Gonçalves,1992, p. 26).
\end{abstract}

Entretanto, nos processos de trabalho em saúde predominantemente positivistas, o objeto de saúde, o homem, foi reduzido, recortado em sua doença, passando a configurar os processos de trabalho referidos à doença.

Historicamente, até há cerca de dois séculos, os processos de trabalho em saúde nas sociedades ocidentais, tiveram como objetos de trabalho a doença-entidade, como no trabalho do xamã, no qual a idéia de doença estava associada à noção de uma entidade, um mal, com vida própria, que também prevaleceu na Idade Média com a demonização preconizada pela medicina cristã. Uma exceção foi o período da Grécia clássica, onde a medicina foi uma prática, concebendo a doença como uma reação espontânea natural (da natureza) ao desequilíbrio, com intenções de cura. A finalidade do processo de trabalho, portanto, estava relacionada ao reconhecimento do tipo de desequilíbrio (diagnóstico), buscando os processos de reequilíbrio (prognóstico).

Todos esses processos de trabalho em saúde, de alguma forma e sob alguns aspectos, deixaram sua contribuição na evolução do trabalho em 
saúde, mesmo a medicina da Idade Média deixou como herança sua organização sob forma de assistência, com as assimetrias e hierarquias nas relações de poder. E como processos de trabalho em saúde, pela sua característica de transformação da natureza na satisfação de carências/necessidades, construíram o mundo da saúde, o campo da saúde e suas teorias, em suas infinitas particularidades, constituindo a diversidade da unidade trabalho em saúde (Vaz,1999).

A partir do século XIX, desenvolveu-se um modelo de organização do trabalho em saúde cuja necessidade referia-se à recuperação da força de trabalho, recortando a doença como alteração morfológica e/ou funcional do corpo humano, do corpo biológico individual. Entretanto, o processo de trabalho baseado nessa concepção somente atingiu seu desenvolvimento pleno no século seguinte, após o desenvolvimento dos instrumentos capazes de realizarem na prática a teoria da doença enquanto alteração morfo-funcional, em outras palavras, capazes de realizarem na prática o diagnóstico. No século XX, portanto, houve um predomínio desse modelo que tornou quase automática a equivalência do trabalho médico como trabalho em saúde (Gonçalves, 1992).

Em síntese, o trabalho em saúde consiste em:

\begin{abstract}
um trabalho essencial para a vida humana e é parte do setor de serviços. É um trabalho da esfera da produção não-material, que se completa no ato de sua produção. [...] O produto é indissolúvel do processo que o produz, é a própria realização da atividade. $\mathrm{O}$ trabalho em saúde envolve um trabalho profissional, realizado por trabalhadores que dominam os conhecimentos e técnicas especiais para assistir o indivíduo ou grupo com problemas de saúde ou com risco de adoecer, em atividades de cunho investigativo, preventivo, curativo ou com o objetivo de reabilitação (Pires, 1999, p. 29).
\end{abstract}

A evolução do processo de trabalho em saúde mental também foi determinada pelas transformações históricas na organização social e no campo do trabalho em saúde, que repercutiram na compreensão do processo saúde-doença mental e no modo de produzir saúde mental em cada tempo histórico.

A emergência do modo de produção capitalista marcaram profundamente o modo como a sociedade ocidental, até hoje, trata os problemas de saúde-doença, dentre eles, o modo de compreender e tratar a 
loucura, recortada pela psiquiatria como um objeto de trabalho reduzido: a doença mental.

Nas instituições totais, o sujeito era colocado entre parênteses, e o objeto de trabalho tornara-se a doença mental, que mantida sob isolamento acabou por sofrer uma exclusão social de grandes proporções. $O$ doente mental não era considerado um sujeito de razão e portanto de direito; não podia celebrar contratos, ou seja, não podia vender sua força de trabalho no mercado, não podia ter propriedades ou direitos, não podia ser escutado em suas opiniões ou decisões por ser um ser irracional, incapaz e ameaçador. Desqualificado como ser produtivo, e portanto, desordeiro, não the foi permitido conviver livremente com os demais, devendo ser recolhido, mesmo contra sua vontade, à reclusão asilar, para ser protegido de si mesmo, educado e controlado, e talvez re-introduzido à convivência social (Castel, 1978).

Como conseqüência desse seqüestro da loucura pela ideologia positivista, pela psiquiatria e seus aparatos institucionais de controle, o sujeito com sofrimento mental foi sendo mais ou menos excluído, mais ou menos tratado e reabilitado, mais ou menos reintegrado conforme as necessidades econômicas de cada sociedade, mascaradas pelas técnicas terapêuticas e reabilitadoras desenvolvidas em cada época, o que corresponde à "coincidência real entre a função técnico-especialista e a estrutura na qual se trabalha", (Basaglia, 1971, p. 5). Para o autor:

\begin{abstract}
Esta objetivação do homem em síndromes, operada pela psiquiatria positivista, tem tido conseqüências extremamente irreversíveis no doente que - originariamente objetivado e restrito nos limites da doença - foi confirmado como categoria fora do humano por uma ciência que devia distanciar-se e excluir aquilo que não estava em grau compreender. Todavia, se é verdade que uma análise científica - qualquer que seja o problema do qual se ocupa - representa a pesquisa do fundamento de um fenômeno, uma vez que ele esteja isolado das superestruturas e das ideologias das quais é habitualmente velado, desejando-se afrontar cientificamente o problema do doente mental se deverá, a princípio, colocar entre parênteses a doença e o modo no qual foi classificada, para poder considerar o doente no seu desenvolver-se em modalidades humanas que - propriamente enquanto tal - devemos procurar avizinhar-nos (Basaglia, 1966 apud Amarante, 1996, p. 77).
\end{abstract}

Nesse sentido, Basaglia propôs uma operação epistemológica: uma inversão dialética da questão psiquiátrica na qual o doente foi isolado, para 
retomar o contato com essa existência complexa e humana, retirando o parênteses do doente e colocando-o sobre a doença, isto é, o saber psiquiátrico que sobre ela se produziu. Ao colocar entre parênteses o fenômeno, Basaglia também operou uma primeira negação, na qual afirmava que o fenômeno é expressão da cultura e da subjetividade do observador, em outras palavras, que a doença mental é uma construção da psiquiatria, determinada muito mais pela ideologia em comparação com a ciência. Entretanto, essa formulação não objetivava negar a existência da doença, mas defendia a recusa da positividade do saber psiquiátrico, negando seu papel meramente ideológico, para ocupar-se de tudo aquilo que se construiu em torno da doença, para retomar a complexidade desse fenômeno (Amarante, 1996).

Considerando a essência do poder psiquiátrico, a Psiquiatria Democrática Italiana introduziu uma nova maneira de conceber a loucura, por meio de uma profunda critica ao paradigma psiquiátrico tradicional, construindo uma reformulação da assistência à saúde mental que estava alicerçada em dois níveis simultâneos, teórico e político, contrapondo-se à totalização do controle operado seja pela centralidade do modelo hospitalocêntrico tradicional seja pela capilaridade multidisciplinar dos serviços comunitários. $\mathrm{O}$ trabalho em saúde mental nesses modelos de atenção, segundo a critica dos reformadores italianos, apenas operaram uma descentralização da dominação exclusiva do saber psiquiátrico, mantendo a natureza de controle dos desvios e dos desviantes.

Como já vimos, a proposta italiana influenciou o processo de reforma psiquiátrica brasileira que se utilizou de muitas formulações para definir os eixos norteadores da reformulação da assistência à saúde mental no país. Essas práticas e saberes desinstitucionalizantes e antimanicomiais podem ser reunidas no chamado campo psicossocial, termo introduzido no Brasil a partir da II Conferência Nacional de Saúde Mental (1992), que definiu a atenção integral e a cidadania como eixos norteadores da atenção, compreendendo o processo de saúde e doença como resultante de um conjunto complexo e indissociável de múltiplas e articuladas determinações. 
O campo psicossocial define portanto uma concepção ampliada do processo saúde-doença mental cujas ações de cuidado se constituem a partir da integralidade e da cidadania a partir de um processo de trabalho em que os operadores compõem uma equipe interdisciplinar, cujo objeto passa a ser o sujeito e suas necessidades complexas e cuja finalidade última é a transformação desse sujeito num cidadão, protagonista de sua história de vida (Oliveira, 2006).

Sendo assim, o campo psicossocial demarca o campo de atuação das propostas de reformulação da atenção em saúde mental operando uma transformação conceitual, assistencial, jurídica, política e cultural sobre o modo de produzir saúde no contexto da reforma psiquiátrica brasileira, isto é, sobre a estruturação e organização dos processos de trabalho que tem por finalidade a desinstitucionalização e a emancipação do louco.

Considerando que o processo de trabalho dos profissionais de saúde tem como finalidade - a ação terapêutica de saúde; como objeto - o indivíduo ou grupos doentes, sadios ou expostos a risco, que necessitam de algum tipo de atenção em saúde; como instrumental de trabalho - os instrumentos $e$ as condutas que representam o nível técnico do conhecimento e o produto final é a própria prestação da assistência em saúde que é produzida no mesmo tempo que é consumida (Pires, 2008); passaremos a analisar alguns componentes e características principais do processo de trabalho em saúde do NOT.

\subsection{Agente Principal: a equipe de Coordenadores}

No cenário estudado, o principal agente do trabalho em saúde, responsável pelo controle do processo de trabalho nas oficinas, é composto pela equipe de coordenadores. Em sua maioria, estes trabalhadores são profissionais da área da saúde, especialmente da saúde mental:

E1.120 (sobre a formação do técnico)- quando você pergunta o papel do coordenador, o coordenador pra mim é um técnico da saúde mental, daí como você quiser chamar.

E7.1 - Eu tenho atividade enquanto enfermeira, alguma supervisão com relação à enfermagem, mas é bem pontual. 
Este profissional coordenador da oficina tem o compromisso de facilitar a articulação dos integrantes, possibilitando a operatividade para atingir os objetivos propostos, e, como educador, de reconhecer a necessidade do sujeito, estimulando-o a fazer descobertas, considerando seus saberes e incluindo-os nas relações interpessoais (Cayres et al., 2001).

Em algumas oficinas, contudo, os coordenadores das oficinas podem ser profissionais de outras áreas, em geral, da área relacionada com a produção específica da oficina, conforme discurso:

E1.117 - A gente optou pro coordenador da oficina de culinária, que antes a gente chamava de culinária, agora divide em duas, é de ser um nutricionista, que eu acho que foi um grande ganho assim pra oficina.

A inclusão de outros profissionais de nível superior, fora do campo da saúde mental, se justifica pela necessidade de utilização de conhecimentos técnicos específicos acerca da organização e do controle da produção na oficina, que na verdade, ficaram evidenciados ao longo do desenvolvimento e qualificação do serviço:

E1.118 - . As nutricionistas que a gente tem, tem um pezinho na clínica, mas tem essa formação do dia-a-dia, da coisa do restaurante, da nutrição mesmo, que é a questão da organização, de compra, isso já faz parte da rotina, a nutricionista aprende isso, quando a gente tinha psicólogo, patinava mais nessa função de coordenar a oficina.

E2.66 - Eu nunca tive informação nenhuma em saúde mental, então pra mim a parte administrativa da oficina é muito fácil...

Essa demanda de diversificação da equipe para outras áreas do conhecimento trouxe como conseqüência a necessidade de capacitação destes profissionais no que se refere à saúde mental, mas também aos profissionais da saúde acerca das tecnologias e técnicas requeridas ao processo de produção na oficina, conforme frases abaixo:

E1.119 - aí o que a gente tem capacitado às meninas é na questão da saúde mental, que aí tem a supervisão, faz a supervisão, porque na questão da dinâmica da oficina é super tranqüilo. Melhorou bastante até. E... enfim, da agrícola , dessas outras é a capacitação mesmo, de aprender também, faz a referência do usuário, mas tem que ir aprendendo dessas outras coisas aí, agricultura orgânica, fitoterapia, jardim, essas coisas. Tem que correr atrás.

E1.112 (capacitação para desenvolver a coordenação da oficina) $\mathrm{Na}$ universidade não. Então já teve capacitação do SEBRAE, as pessoas buscam, na medida do possível a associação também viabiliza o pagamento de alguma capacitação ou específica, enfim... 
Vai se capacitando ao longo do tempo, de saber daquela técnica específica...

Essa necessidade de capacitação dos coordenadores em outras áreas do conhecimento, requisitadas ao planejamento e andamento do processo de trabalho no interior da oficina, por meio da instrumentalização de técnicas diferentes da sua formação profissional, é vista como uma ampliação do campo de atuação, mas se traduz em estranhamento e dificuldade para alguns:

E7.20 (função de coordenador) - Então, na realidade, vai te ampliando muito seu campo de atuação.

E2.70 - sou coordenadora, não sei bem o que eu sou...

E10.8 (trabalho na saúde mental) - é um trabalho completamente diferente da minha área, nunca imaginei trabalhar nisso que eu estou trabalhando hoje.

E10.9 - pra mim a parte de produção, de cardápio, de orçamento é tranqüilo, mas a parte de lidar com a saúde mental, de lidar com esse trabalho é difícil, no começo eu tive um pouco de dificuldade, porque eu tive que aprender uma coisa que eu nunca tive contato, mas hoje eu adoro.

Por conseguinte, o perfil desse profissional necessariamente requer o interesse e a disponibilidade em aprender e desenvolver outras práticas para além da sua formação inicial, demandadas tanto pelo projeto quanto pela execução de seu trabalho dentro da oficina:

E1.116 (perfil do coordenador) - Eu acho que ele tem que ser dinâmico, ter vontade de aprender, ser curioso, empreendedor, acho que tem que ter essas características principais...

Nesse sentido, o serviço estabelece espaços freqüentes de discussão coletiva, que possibilitam a reflexão e planejamento conjunto de ações voltadas ao acompanhamento dos usuários e à organização institucional, como reuniões de equipe e supervisão clínico-institucional quinzenais:

E4.78 - A gente tem a reunião de equipe, e agora a gente está tendo a reunião de planejamento aqui do NOT, e temos a supervisão também de caso, com o X, que também é de terça-feira, de quinze em quinze dias.

E1.148 - E na equipe técnica, os coordenadores, aí envolve tanto a questão do oficineiro relacionado à saúde mental, de como incluir aquele que tem mais dificuldade, que contratos fazer, essas questões a gente discute em supervisão, e mesmo na reunião de equipe. 
Esses espaços de discussão entre a equipe são definidos institucionalmente como parte das atividades exigidas pelo serviço mas também são organizados pelos próprios coordenadores em função da necessidade de troca de informações:

E4.79 - E a gente também tem um grupo, que é da "Roda NOT", que a gente fala por email, onde a gente também faz algumas trocas, às vezes uma tira dúvidas da outra, uma encaminha alguma coisa. Tem esse espaço também.

E4.80 - E diariamente também, a gente conversa em horário de almoço, toda a equipe está sempre junta.

Tanto a ampliação e troca de conhecimentos quanto à colaboração que caracterizam as relações de trabalho entre os coordenadores, permitem identificar como resultado do processo de trabalho do NOT, a transformação dos sujeitos no que se refere ao domínio das técnicas de produção, mas também à ampliação de suas necessidades e, consequentemente, de sua consciência social sobre o próprio trabalho:

E7.103 - pra gente também enquanto profissionais, é uma transformação porque você vai vendo que com o tempo você vai tendo mais amadurecimento pra lidar, vai ficando mais serena, mais centralizada, mais assim, e tem um acúmulo...

E7.29 - Então é um leque muito grande de ação, e acho que a gente tem que se cuidar, com o tempo você vai tendo um pouco mais de maturidade, de sabedoria, vai assentando algumas coisas, mas você não pode se descuidar que a intensidade das coisas não diminui.

E9.2 (trabalho na saúde mental) - foi um pouco estranho no começo, porque eu tinha um preconceito mesmo, muito grande, e a minha primeira pergunta que eu fiz pra mim mesma assim: será que eles não vão fugir? Será que não vão escapar daqui? Como será que funciona isso? Porque eu tinha aquela idéia antiga de doença mental de hospital psiquiátrico.

E9.3 - Eu fui me espantando muito ao ver como as pessoas, como a doença se instala, e percebi que o preconceito é um dos fatores mais, é um dos principais fatores pra fazer com que essa doença permaneça no indivíduo...

E9.4 - então quanto mais limpeza você tiver em termos de preconceito, quanto menos barreiras você colocar, eu acho que você ajuda muito na recuperação de algumas pessoas. Tem alguns casos que não tem, não dependem disso, dependem de vários outros fatores, mas com certeza eu acho que esse olhar humanitário ajuda muito.

Esse enriquecimento qualitativo possibilitado pelo trabalho em equipe e pelo exercício da criatividade, da autonomia e da aprendizagem, também é 
visto como conseqüência da relação com os oficineiros, objeto de trabalho do NOT, cuja transformação confirma e valoriza a atuação do profissional, proporcionando reconhecimento profissional e também pessoal:

E8.66 - eu avalio o trabalho, é um trabalho muito gostoso. Porque é muito rápida a resposta sabe, dos investimentos que você vai fazendo na oficina, com o oficineiro, você vê ali o resultado, a satisfação, a gratidão...

E3.73 (avaliação do trabalho) - Intenso, dinâmico, gostoso, criativo e me sinto alimentada por eles mesmos. Quando você vê o esforço do seu trabalho, assim, recompensado pela melhora deles.

E7.78 - eu acho que é de uma riqueza profissionalmente, mas pede muitas coisas pra você dar conta, sabe? São dificuldades, não são impossibilidades, você tem que aprender a administrar, no dia a dia.

E9.7 - Então foi muito gratificante pra mim, eu acho que eu cresci muito como pessoa, eu tenho duas filhas e pelos anos que estou aqui, acredito que eu pude passar pra elas mais coisas e melhores que eu não teria conseguido sem essa experiência.

A superação da lógica manicomial, como vimos, implica num posicionamento político e num alinhamento conceitual das instituições ao modo psicossocial que se traduzem em dispositivos teórico-práticos, instrumentos de transformação das práticas cotidianas das instituições, sobretudo das relações destas com os usuários, isto é, se traduzem em mudanças nos modos de trabalho desses serviços no sentido da horizontalização nas relações "com a distinção obrigatória entre as esferas do poder decisório, de origem política e as esferas do poder de coordenação, de natureza mais operativa" (Costa-Rosa, Luzio, Yasui, 2001, p. 14).

Nesse sentido, torna-se imperativo a transformação do processo de trabalho em saúde mental, no qual o objeto deixe de ser o sujeito recortado em sua doença pelo modelo médico e fragmentado pela divisão do trabalho em diferentes disciplinas e no qual o agente trabalhador em saúde, ciente de sua função de dominação na luta de classes, redefina seu papel e reoriente sua prática (instrumentos de intervenção), configurando sua identidade ao lado das classes trabalhadoras (Brasil, 1992 apud Costa-Rosa, Luzio, Yasui, 2001). 


\subsection{Objeto do Trabalho em saúde: oficineiros do NOT}

Segundo o projeto institucional o processo de trabalho do NOT iniciase no sujeito, com suas expectativas e necessidades de ocupação e gratificação (Cayres et al., 2001).

Como vimos, o público a que se destinam as ações do NOT é composto pelos usuários de saúde mental do município de Campinas que estejam sendo assistidos por algum serviço de atenção pública ou privada. Entretanto para ter acesso ao serviço, este usuário deve ser encaminhado pelo serviço de referência e enquadrar-se nos critérios, conforme apontado na análise do acesso e adesão.

Esses critérios de acesso e adesão nos permitem identificar o recorte do objeto de trabalho do serviço NOT, que também se baseia na sua missão institucional e no grau de complexidade de assistência do serviço no interior da rede de atenção psicossocial. Sendo assim, podemos afirmar que o objeto de trabalho do NOT refere-se aos usuários de serviços de saúde mental, diagnosticados com algum transtorno mental (incluindo aqueles decorrentes do consumo de substâncias psicoativas e em alguns casos, deficientes mentais) que estão sendo assistidos por algum tipo de tratamento especializado e que necessitem de ações de cunho reabilitativo (sem descartar as assistenciais) para sua reinserção social.

E7.42 - ...você recebe... um psicótico grave ou um neurótico grave ou um deficiente mental, que às vezes fica difícil dele se adaptar, aí você tem que ter todo um jeito, às vezes é um psicótico com uma deficiência, às vezes é um alcoolista, às vezes é um epilético, às vezes é uma histérica grave, então você nunca sabe como vai, então, você senta, você está diante da oficina, você tem todas essas pessoas circulando, e aí você tem que ter todo um jeito pra lidar com um lidar com outro.

E3.21 (limite/dificuldade) - e com essa estrutura, um coordenador e um monitor, numa oficina com diagnósticos de psicose, de dependência química e também tem co-morbidade...

E11.6 (proposta da oficina) - eu tenho um grupo com pessoas com sintomas, ou melhor, com diagnósticos diferentes, tem alcoolistas, têm psicóticos, tem drogaditos, têm os depressivos, pessoas com deficiência mental, então é uma mistura assim grande, pro mesmo tipo assim de atividades que são desenvolvidas na oficina.

Essa heterogeneidade do objeto de trabalho, que apresenta características específicas quanto ao manejo e à assistência, se traduz 
dentro do processo de trabalho na necessidade do profissional em diagnosticar os problemas singulares de cada usuário, relacionadas às suas capacidades e limites, para planejar e desenvolver intervenções (cuidados e procedimentos) que possibilitem sua participação no grupo e na execução das atividades na oficina, identificando também seus interesses e necessidades.

E7.53 - ...a gente fala que é NOT um e NOT dois, que tem pacientes que tem uma demanda, claro todo mundo quer ter uma renda, mas eles têm uma necessidade de convivência.

E9.26 - quando você trabalha com pessoal que faz uso de álcool e drogas, então, eles geralmente vem assim, acabando, acabou de sair de uma crise e entra na oficina, num momento que ele está começando a se estabilizar, então às vezes, ele tem as recaídas dele e às vezes numa recaída maior ou alguma coisa ele acaba se desvinculando, perdendo o vinculo com a oficina.

Considerando a especificidade do trabalho em saúde, no qual o objeto é o homem, este deve ser apreendido em sua objetividade e também em sua subjetividade, em outras palavras, não apenas considerar o pensamento e a ação humanas, mas também as relações, que são mediadas por desejos, afetos, paixões, repulsas, ódios, normatividade e trabalho, que cada homem estabelece com a totalidade em que vem a ser, e como suas partes, incluindo ele próprio, e que fazem dele um sujeito (Gonçalves,1992). A compreensão de subjetividade humana como característica objetiva da natureza humana, história e culturalmente construída, refere-se a algo que está em permanente vir a ser, algo imediatamente sócio-histórico em sua própria individualidade, que por sua vez, desdobra-se na capacidade humana de ser normativa em relação à natureza e a si mesmo.

No caso das oficinas do NOT, identificamos essa preocupação de considerar o objeto de trabalho em toda sua dimensão objetiva e subjetiva, como algo em movimento, para favorecer a permanência e a participação do usuário na oficina, e ao mesmo tempo assegurar a continuidade da produção do grupo de trabalho, conforme fragmentos abaixo:

E9.58 - Porque tem oficinas, cada oficina pode acolher vários tipos de pessoas, em todos os estágios da doença, então a pessoa praticamente numa crise, sabe, com crise, estabilizado, se estabilizando, recaindo ou não, você consegue manejar as funções e as ocupações de forma a atender a demanda. 
E8.61 - Eu acho que o coordenador é um profissional muito flexível, porque ao mesmo tempo em que ele tem que cuidar da produção, que tem a qualidade, que seja inovada o tempo todo, ele também tem que cuidar do oficineiro, pra que ele esteja bem, se sinta reconhecido, feliz, que seja remunerado justamente, poder ouvir a angústia dele, o sofrimento, fazer o devido encaminhamento, com todo cuidado...

Nesse sentido, o objeto de trabalho se ampliaria para o interior do processo de produção na oficina, instrumento do trabalho em saúde. O papel do coordenador da oficina estaria relacionado à assistência do usuário no contexto das relações com o grupo de produção, entretanto sua função também relaciona-se ao controle do processo de produção na oficina, conforme declarado pelos entrevistados acerca de sua função:

E3.61 - As minhas tarefas são divididas em dois aspectos grandes, que eu diria. Então, é o aspecto do cuidado e o aspecto comercial...

E2.1 - Administração da oficina, todas as rotinas administrativas e técnicas, assistência aos usuários e participação na equipe e trabalho com outros profissionais.

E4.1 (atividades desenvolvidas) - Tem as atividades administrativas, tem atividades referentes à assistência dos usuários, tem as atividades comerciais...

E8.9 - Então o coordenador ele é responsável pela parte administrativa, e pela parte assistencial da oficina.

E1.111 - O papel do coordenador da oficina é bem amplo assim... Não é psicólogo que vai fazer psicoterapia e só... Tem o núcleo do psicólogo, mas na oficina, o papel é coordenar a oficina e estar implicado com todas as questões da oficina, desde a produção, a referência do usuário, compra de material, enfim, tudo que diz respeito àquela oficina.

Nesse sentido, as atividades mencionadas pelos entrevistados estão dirigidas tanto à assistência dos oficineiros, quanto à organização do trabalho na oficina, o que nos permite inferir a preocupação e responsabilização do coordenador nesses dois campos de atuação: a assistência ao usuário e o controle da produção, instrumentos de intervenção do agente-coordenador cuja finalidade dirige-se à reabilitação psicossocial pelo trabalho do objeto-oficineiro. 


\subsection{Instrumentos: Atenção Psicossocial e Controle do Processo de Produção}

Retomando a conceituação do processo de trabalho, os instrumentos correspondem às formas materiais e não materiais que possibilitam a apreensão do objeto, que se colocam entre o trabalhador e o objeto ao qual se aplica o trabalho, no caso da saúde, o ser humano com seus carecimentos.

Essa dupla responsabilidade do coordenador em conduzir os dois instrumentos (assistência e produção) ao mesmo tempo pode gerar alguns conflitos e contradições durante o processo de trabalho, que ora poderá privilegiar seu olhar sobre o oficineiro, ora sobre a oficina, ora atuar como um profissional de saúde ora como um supervisor de produção, cujos interesses nem sempre são conciliáveis:

E1.44 - ...a gente recebe esta pessoa e tenta incluir respeitando o desejo dela, o que ela quer fazer, enfim, então, nem sempre vem alguém que... vem um pedreiro quando você precisa de um pedreiro, às vezes vem um que quer aprender ser pedreiro, então...

E1.49 (contratos)- A gente tenta respeitar, conciliar as duas necessidades, nem sempre é possível.

E8.64 - É muito difícil a gente tem que dar conta da produção, no momento que está muito rápido, e cuidar também daquele oficineiro que chegou angustiado naquele dia, então você tem que ser flexível, você tem que ter jogo de cintura...

E1.43 (sobre o projeto institucional) -Às vezes você fala assim: precisaria que viesse um usuário, assim bem bonzinho para fazer isso. Mas nem sempre vem. A gente acaba recebendo pessoas que são encaminhadas, tem projeto terapêutico individual em que 0 trabalho tem uma função importante aí...

Esse duplo olhar se expressa também no momento de inserção do oficineiro, quando os coordenadores às vezes dão preferência aos usuários que disponham de algum grau de experiência ou habilidade técnica para favorecer o processo de produção na oficina, conforme fragmentos de texto abaixo:

E1.48 - Então aí é que eu acho que tem algumas contradições, ora a gente acaba tendo que priorizar a questão da produção, da geração de renda, dos compromissos assumidos, e aí aquele que viria se tem dois pra ser chamado, e tem outro que já tem uma habilidade posta, você acaba chamando e o outro espera um pouquinho. Tem estas coisas... que a gente as vezes tem que fazer. Não dá pra dizer que não faz. 
E1.47 - Às vezes você respeita a oficina, às vezes o desejo do sujeito, deixa um esperando um pouquinho mais e chama o outro, para respeitar os contratos...

E11.51 - Só que assim, a gente tem procurado dentro das pessoas que têm sido encaminhadas pra gente, a gente tem procurado pessoas que conseguem ser, dentro da oficina, vitralistas. Que conseguem realmente confeccionar um vitral. Dentro disso, a gente vai poder atingir um mercado de arquitetos.

Por outro lado, essa necessidade de responder à demanda de produção na oficina, segundo os entrevistados, produz também uma ampliação de vagas, devido à falta de habilidade e à inconstância de participação dos oficineiros motivada por vários fatores: faltas, afastamento para tratamento, dificuldade em trabalhar por uma jornada inteira, entre outros.

E1.50 - Aí, outra coisa que a gente lança mão aí é isso: um trabalho que a você faria com um, você inclui três, para compensar as habilidades e dificuldades de cada um.

E7.63 - Tem pessoas que tão ficando idosas que não conseguem trabalhar o dia todo. Você vai dando um jeito.

E7.64 - Na minha oficina eu tenho quatro numa vaga só. Então um que vem três manhãs, uma que vem três tardes, um que um dia vem outro dia não vem. Então pra ocupar, pra ficar uma vaga só também não tenho pessoas, e nem dou oportunidades pra outras pessoas. A gente vai adaptando...

A preocupação com o processo de produção na oficina, na verdade, é resultado de uma mudança de projeto do NOT, que ao longo de sua experiência, incorporou o processo de trabalho na oficina como um importante instrumento para a finalidade de reinserção social dos usuários, como se depreende das frases temáticas abaixo:

E4.25 - existe uma história do NOT que quando ele foi construído, quando ele foi pensado, seria um espaço onde fosse um espaço de passagem, um lugar de passagem, que eles, os usuários, os oficineiros, eles viriam, aprenderiam um oficio, e depois eles seriam reinseridos na sociedade.

E9.34 - Isso foi uma discussão que a gente teve há uns cinco anos atrás, quando começou a se falar assim que, qual era a nossa missão, era dar uma função pra pessoa, profissionalizar alguém e jogar essa pessoa no mercado.

E7.15 - O início das oficinas a idéia de que o NOT fosse uma passagem que ele pudesse voltar pra um mercado formal mas, pra gente que está um pouco mais normal, pelo que você estava contando já é difícil a gente sobreviver, imagine quem tem uma história assim. 
$\mathrm{Na}$ ocasião de sua criação, o objetivo do NOT era de reabilitar os oficineiros para o trabalho, a partir da sua profissionalização, para "por si ou com a ajuda dos técnicos, se lançarem ao mercado formal de trabalho em busca de um lugar ao sol" (Alcântara, 2007, p.172).

A expectativa de trabalho assalariado, formalizado através de um contrato, que ainda permanece entre os técnicos e oficineiros, posto ser o trabalho com carteira assinada um valor reconhecido socialmente inclusive pela legislação brasileira, na maioria das vezes não é correspondida, especialmente com a drástica redução dos postos de trabalho que atinge o mundo do trabalho atual. Esses obstáculos à inclusão no mercado de trabalho relacionados à dimensão mais estrutural do trabalho, aparece em alguns discursos como uma dificuldade maior ainda para as pessoas com sofrimento mental, como abaixo:

E9.39 - porque se você forma o cara e solta na rua, não tinha emprego nem pros profissionais, muito menos pro pessoal com sofrimento mental.

E5.8 - tem vezes que a gente sabe hoje em dia que pra um sujeito dito normal já é difícil um emprego no mercado formal, imagina um oficineiro que tenha todos os problemas de medicação, recaída, remédio, tratamento, seguimento em CAPS, centro de saúde.

Dessa maneira, além da profissionalização, insuficiente para incluir o oficineiro no mercado de trabalho formal, as oficinas de trabalho do NOT passaram a preocupar-se com a qualidade da produção e com o mercado de consumo, uma vez que o produto das oficinas deveria ter condições de comercialização para dele se obter os recursos (renda) para os usuários.

E9.37 - Então é um questionamento que a gente começou a fazer, então eu vou investir três anos, não sei quantos anos numa pessoa, quando ele tiver bem, eu pego, coloco ele no mercado pra ele trabalhar...

E9.41 (produção) - Porque antes era assim, o que você conseguiu fazer você faz, daí a gente vai correr pra ver se consegue vender, a gente inverteu, daí, então assim, o quê que o cliente quer? Isso? Então vamos fazer o que ele quer e...

Essa transformação no projeto institucional redirecionou todo o processo de trabalho do NOT com relação ao processo de produção na oficina, antes considerada apenas um espaço de capacitação, tornando-se um importante instrumento para a reinserção social por meio do trabalho e 
da geração de renda adquirida com a comercialização da produção da oficina:

E9.38 - .... gente começou a pensar sobre isso e concordamos em criar o mercado lá dentro mesmo, ao invés de procurar depois, porque a gente tinha responsabilidade de conseguir o mercado pra eles...

E9.40 - Então a gente começou a abrir o campo pra eles, dentro das oficinas, mediante a profissionalização do próprio trabalho, da equipe, numa estrutura organizacional mais direcionada para venda, e mais atendendo a demanda dos clientes do que as nossas.

Esse redirecionamento do projeto do NOT exigiu uma flexibilidade também na atuação dos coordenadores, que enfrentam o desafio de inserir e assistir o usuário na oficina sem prejudicar o andamento da produção, incorporando outras responsabilidades como o zelo pela qualidade dos produtos e sua comercialização, como verificado nos fragmentos a seguir:

E7.22 - A gente ficou um bom tempo trabalhando, a gente percebe que agora a gente consegue ficar com pé nos dois.

E7.61 - porque a gente não pode desassistir, não participar da oficina, até porque isso é uma questão política, a gente não pode tomar essa decisão até porque as pessoas do município tem um trabalho da instituição em parceria com a Secretaria, de co-gestão, que tem que responder.

Esse desafio também se observa pela necessidade, apontada por um dos entrevistados, em rever as funções dos trabalhadores do NOT, no sentido de adequar-se ao crescimento do serviço e seu projeto institucional:

E1.146 - E do processo de trabalho da equipe, do coordenador, que acho que é bastante angustiante, a gente ser da saúde, é não ter uma formação específica pra gerir, e fazer a gestão do negócio.

E8.7 - Inclusive a gente está revendo, as funções do coordenador, do monitor, a gente está escrevendo isso.

E8.8 - Porque o NOT cresceu muito, e a gente está revendo papeis, funções, sempre pra tentar aprimorar, melhorar, aperfeiçoar.

Tanto a instituição como os entrevistados afirmam existir um esforço contínuo da equipe em conciliar a demanda de produção com as necessidades terapêutico-sociais dos oficineiros, considerando a dificuldade de atuar nesses dois campos tão complexos(Alcântara, 2007, p. 168):

Funcionar dessa maneira não é tarefa fácil. Vivemos numa sociedade onde o sistema de produção dominante é o capitalista, e 
foi sob esses princípios que fomos educados ou treinados. Por esse motivo, é necessário que haja um exercício diário entre os técnicos, principalmente, para não cair nas armadilhas da reprodução do modelo normatizador e disciplinador do trabalho.

Como apontado pelo texto acima, o desafio de não reproduzir as relações sociais de produção no interior do processo de trabalho nas oficinas, entretanto, não depende apenas da intenção afirmativa da instituição mas necessariamente coloca como imperativo uma profunda revisão teórica do papel do trabalho na sociedade e nas instituições, em particular, nas instituições psiquiátricas cujo modelo de assistência que predominou corpos e mentes baseava-se na normatividade social. Os operadores desse modelo, trabalhadores de saúde mental, conscientes ou não, na singularidade da sua relação com o usuário, realizavam o papel particular de controle social da psiquiatria em sua relação com a estrutura social para a manutenção da ordem.

Nesse sentido, para a transformação dessa lógica ainda presente torna-se imperativo o questionamento e a reformulação dos profissionais da função social que thes foi determinada, buscando negar essa lógica e construir juntamente com os destinatários da assistência uma relação baseada na cooperação, no respeito mútuo e no posicionamento social na luta de classes.

De acordo com os entrevistados, as atividades desenvolvidas pelo coordenador, portanto, estão relacionadas à assistência ao oficineiro, à produção e comercialização dos produtos. Esses dois campos de atuação configuram diferentes tipos de competências exigidas pelo projeto e execução do processo de trabalho do NOT, de domínio principal, mas nãoexclusivo, do conjunto de coordenadores das oficinas.

No campo da assistência ao usuário, cuja finalidade está vinculada à manutenção do quadro estável (em condições de socialização e produção), os coordenadores fazem uso de conhecimentos e intervenções de natureza clínica. Em primeiro lugar, realizam o acolhimento diário do usuário, avaliando suas condições psíquicas, e desenvolvem os procedimentos necessários:

E3.62 - enquanto coordenadora da oficina eu tenho que acolher esse oficineiro que chega no seu dia a dia... 
E3.63 - Como ele esta chegando, como passou seu dia, como passou sua noite, como está, se tomou seu remédio e observar, principalmente, os dependentes químicos, se eles estão em condições de estar no grupo ou não. É a hora da chegada deles...

E1.174 - Então de manhã nesse momento que a gente se encontra também tem essa observação, ver se está bem, se não está, se bebeu, se não bebeu, porque se estiver alcoolizado não dá pra trabalhar. Daí não dá.

E1.175 (manejo em caso de intoxicação) - Ou encaminha de volta pro CAPS ou manda pra casa, dormir, depende do caso.

Nesse aspecto, os entrevistados apontam para a importância do estabelecimento do vínculo com os usuários, possibilitando e favorecendo a expressão de suas necessidades e de suas opiniões, promovendo assim tanto a autonomia do usuário quanto a responsabilização do profissional.

Esses dois instrumentos de intervenção (acolhimento diário e estabelecimento de vínculo) desenvolvidos em parceria com o usuário, portanto, alinham-se ao modelo de atenção psicossocial, uma vez que promovem um papel mais ativo do usuário no cuidado, desburocratizando também a relação terapêutica e formando uma aliança terapêutica baseada na singularidade e na invenção de intervenções que considerem as necessidades do usuário e não da instituição:

E3.64 - E mesmo o vínculo que se estabelece, é a linha mestra.... Eles chegam e já vão te avisar: olha, eu não estou bom hoje não. Existe muito isso na relação já.

E1.177 - Então eles já sabem que não pode ir, às vezes vem, fala: ah, não estou bom, vim aqui, mas não estou bom; no sentido de pedir ajuda, aí ou você encaminha pro pronto socorro pra desintoxicar, aí dá o encaminhamento que for conveniente aí pro caso, não tem uma regra. Têm outros que deixa aqui até passar, espera almoçar, fica por aqui, outros, tem alguns que se mandar pra casa vai beber mais ainda, por isso fica aqui, e esses aí você vai tentando conversar, contornar, ver o que aconteceu...

Outro instrumento de intervenção, desvelado pelos discursos como uma das atividades do coordenador, refere-se à escuta do sofrimento mental, que, como referimos, pode ou não resultar em encaminhamento para o serviço de referência a depender da intensidade de acompanhamento. Segundo os relatos, os usuários referem conflitos e dificuldades que, geralmente, são aliviados por meio dessa escuta (individual ou grupal), proporcionando a retomada das atividades produtivas: 
E3.65 - Aqueles que precisam de escuta mais tempo, principalmente às segundas-feiras é o que acontece mais. É o dia em que eles estiveram o final de semana com sua família, e vêm com muitas questões.

E3.66 - Os esquizofrênicos vêm com uma confusão muito grande, querendo, muitas vezes, uma escuta, uma conversa, um acerto ali, eles já voltam pro trabalho, e eles conseguem, a gente consegue assim, manejar direitinho.

E7.5 - ...ela é uma assistência de um contato individual de uma escuta individual, é uma escuta de grupo, pra poder trabalhar a relação, a convivência, pra poder estar produzindo, em parceria, em conjunto, é esse trabalho, tanto individual quanto em grupo...

E2.64 - a gente trabalha bem o grupo, mas dá bastante assistência individual também, eles procuram muito, assim conversar, ou algum encaminhamento ou algum remédio ou está brigando com o marido, quer separar, tudo eles vêm pedir, tudo,tudo.

Os fragmentos acima nos permitem identificar uma aproximação com o sentido do trabalho na experiência italiana de empresa social cujo papel do trabalho relaciona-se à construção da solidariedade, onde as relações de ajuda e de cura se enraízam e se multiplicam com as opções, vinculadas com a vida real, visto que a razão dessa relações está voltada à devolução da riqueza subjetiva da vida (Leonardis, Amauri, Rotelli, 1995).

Em alguns casos, é realizado o encaminhamento do usuário para atendimento em outro serviço de saúde, principalmente nas situações onde as intervenções oferecidas pelo serviço são consideradas insuficientes às necessidades de saúde do usuário, conforme os fragmentos dos discursos:

E8.12 - Se necessário fazer encaminhamento pro CAPS, centro de saúde, se a própria oficina não da conta da parte assistencial a gente faz o devido encaminhamento com o acompanhamento.

E1.96 - Mas tem isso, aparece, a gente está lidando com as pessoas, não tem como. Aparece tudo, desde o gás que não tem em casa até a briga com a mulher, o filho que foi expulso da escola, aparece tudo. Aí tem coisa que a gente, na medida do possível, que você pode ajudar, oferece escuta, às vezes tranqüiliza, e quando extrapola a escuta que a gente pode oferecer, o que a gente pode ajudar, encaminha para o serviço de volta para tentar...

E1.95 - Tinha um paciente no grupo $X$ que é um grupo de homens, de alcoolistas, e tinha um paciente psicótico que tinha a sensação de que ia virar travesti, tinha todo um quadro delirante. E toda vez que ele vinha, ele trazia para mim estas coisas. Ele dizia: ah eu fico angustiado, eu tenho que falar. E eu falava: no grupo você não fala isso, isso você vai lidar lá com sua terapeuta, como uma questão de preservar. 
E1.93 - Tem pessoas que trazem ali as questões que: ah eu não estou conseguindo trabalhar direito esta semana porque estou com problemas " $x$ " ou " $y$ " e traz para o grupo. Daí o grupo devolve, ah, mas isso não é aqui ou isso é aqui, ou você pode fazer deste jeito, e aí a gente vê o que encaminha.

Sendo assim, a articulação com a rede de atenção é considerada uma responsabilidade do coordenador, que envolve não apenas o acompanhamento e adequação da freqüência do usuário no serviço de tratamento e do projeto terapêutico individual, especialmente com relação à medicação, como também avaliar o resultado das intervenções assistenciais no contexto familiar e social, conforme frases abaixo:

E7.72 - Isso acho que do, pro lado da assistência, da articulação dos outros serviços junto com a rede, negociar.

E11.5 - vê como que está toda estrutura dele social, dentro daqui como fora daqui também, se está tudo bem lá fora, familiar, dentro da oficina e se ele continua os atendimentos, então é manter isso.

E11.2 - a gente vê desde se a pessoa está fazendo acompanhamento, se está tomando a medicação, se está indo no local de atendimento...

E2.69 - Então procura essa rede de ajuda, mas, é mais solicitada a parte da assistência, do cuidado, do olhar, do que na verdade a parte da nutrição.

E4.3 - Basicamente, é administrativa e assistencial, também tem o contato com a rede toda, referente aos usuários, se não estão bem, os encaminhamentos.

E7.19 - nessa função de coordenador, nessas atividades, não é muito simples, que você faz assistência, então assim, é o sujeito, é a família, é o serviço onde ele está inserido, é o território onde está esse sujeito, e qual é o território que a gente, o NOT está, quando você pensa também na questão do mercado.

Nesse sentido, podemos identificar uma preocupação com a integralidade da assistência à saúde mental, coerente com o modelo de atenção psicossocial que objetiva a elaboração de ações relacionadas às necessidades dos sujeitos a partir da articulação em rede entre vários serviços (intersetorialidade), considerando os atores sociais (usuário, família, comunidade) e os recursos do território, buscando responder a complexidade das demandas das pessoas com sofrimento mental.

A reorientação do modelo assistencial em direção à atenção psicossocial fundamenta-se na concepção de saúde como processo e não como ausência de doença, enfatizando a integralidade das ações por meio 
da experimentação de novas tecnologias planejadas e executadas coletivamente cuja finalidade é buscar respostas às necessidades complexas do sujeito com sofrimento mental, em contraposição à cura e adaptabilidade social que orientaram às intervenções terapêuticas da psiquiatria positivista (Aranha e Silva, Fonseca, 2005).

O registro em prontuários também foi mencionado como uma das funções do coordenador de oficina que possibilita o acompanhamento e evolução dos casos assistidos pelo NOT assim como das intercorrências e procedimentos utilizados durante a participação do oficineiro no NOT:

E6.3 - todos os prontuários ficam aqui. E todo mês a gente tem que evoluir, pra ver como que está indo cada um deles.

E8.65 - E dar conta ainda das outras atividades administrativas que são chatas: fazer evolução de prontuário, preencher relatório, enfim.

Todos os instrumentos de intervenção foram apontados pelos entrevistados como ações de natureza assistencial que visam o acompanhamento diário do oficineiro durante toda a evolução dele na oficina, uma das finalidades do processo de trabalho em saúde do serviço:

E3.17 - que a gente procura trabalhar essa inserção no dia a dia. A gente percebe, assim, o quanto ele vai melhorando...

E5.17 - A gente vai acompanhando passo a passo 0 desenvolvimento dele lá.

E8.11 - E na parte assistencial fazer o acolhimento, fazer escuta, sempre um primeiro atendimento é na oficina, estar sempre avaliando o tempo todo no dia a dia, como o usuário está, se a atividade está adequada pra ele, como orientar, junto com o monitor.

E11.4 - umas das principais mesmo é você fazer o acompanhamento desse oficineiro dentro da oficina em todas as etapas dele, o inicio dele, depois, quando ele está mais vinculado com o grupo e depois manter esse acompanhamento, que seriam as coisas principais...

E11.8 - esse acompanhamento diário que a gente faz, coordenador, monitor, é o que mantém a oficina assim legal como está.

\subsection{Parcelamento do Trabalho: os agentes e a divisão do trabalho}

Neste momento, cabe incluir outro trabalhador do NOT, cuja participação é fundamental tanto no processo de trabalho em saúde quanto no processo de produção das oficinas: o monitor. Esse agente de trabalho 
deve necessariamente possuir habilidades técnicas relacionadas ao processo de produção na oficina, mas por ser responsável pelo treinamento dos oficineiros e pelo acompanhamento da produção, deverá ser capacitado e orientado pela equipe técnica para lidar com o usuário de saúde mental mediante treinamento em serviço como afirmam alguns fragmentos de discursos:

E1.121 - O monitor também, pra determinadas oficinas tem que ter uma formação específica, não dá pra pôr na construção um cara que não saiba de pedreiro, tem que saber, não dá pra pôr na agrícola, no jardim, uma pessoa que nunca fez jardim, tem que ser um pouquinho jardineiro já, então a gente tem contratado pessoas já com esse perfil. E a capacitação de como lidar com o usuário, com os oficineiros, com a questão da saúde mental, é o que a gente vai fazendo no dia-a-dia assim, oferecendo capacitação, formação...

E1.122 (sobre a capacitação técnica do monitor) - Ele não é um técnico de nível nenhum. Tem sim uma habilidade técnica.

E1.115 - Então além dele ter que ter o bom senso, conhecer e se capacitar acerca dessa população que a gente lida que é da saúde mental, ele tem também que aprender a fazer a tarefa específica, então ai vai capacitando no trabalho, fazendo curso, enfim...

E1.147 - a gente também utiliza dos espaços de reunião de equipe, supervisão pra monitores, mais relacionada ao campo da saúde mental e na verdade os monitores, a técnica específica da oficina, do que eles tem que fazer, da atividade, a técnica, o serralheiro, o marceneiro, isso eles sabem. Eles têm às vezes dificuldades em como lidar com o oficineiro, com o manejo, enfim, essa questão mais delicada do dia a dia. Então nisso a gente também tenta fazer conversando, discutindo, problematizando e trazendo pra fóruns mais ampliados.

O monitor, portanto, é um agente do processo de trabalho, que em alguns casos pode ser um oficineiro capacitado, contratado pela instituição para desempenhar um papel de apoio ao coordenador no que se refere ao controle do processo de produção na oficina, desenvolvendo atividades relacionadas à capacitação dos oficineiros, ao planejamento, organização e acompanhamento da produção (divisão de tarefas), e também à avaliação do desempenho de cada usuário, segundo captado nos discursos:

E1.124 - o papel dele é de instrutor, ele tem que acolher as pessoas do grupo, ensinar, conhecer da técnica específica pra poder passar isso e... enfim, ter um certo bom senso pra lidar com isso. $E$ também intermediar situações do grupo que ele está acompanhando, dupla função ai. 
E2.40 - Tenho duas monitoras que também ajudam na parte administrativa, compra, higiene, ajudam na cozinha também, então está sempre acompanhando eles.

E4.23 (processo de avaliação) - aí a gente senta, eu e os monitores, a gente faz uma avaliação, ele vai pra uma outra função.

E4.75 (organização do trabalho)- De manhã tem uma conversa. Assim, pra organizar o trabalho do dia, com certeza com o monitor, tem o monitor, eles que dividem o trabalho.

E1.123 (sobre monitor ser usuário) - Não, não necessariamente. Eu tenho, na marcenaria, por exemplo, o monitor é um ex-usuário, ele era um ex-oficineiro, ele era oficineiro que tinha uma experiência em marcenaria, sempre trabalhou com o pai nisso enfim, e aí ele era da oficina, quando o monitor que tinha saiu, ele foi contratado como um monitor. No ladrilho que não também precisava de nenhuma... especifica, ia ter que aprender a fazer o ladrilho, era um oficineiro também que acabou sendo contratado, e nas outras, quando tem oficineiro que está desempenhando e tem perfil pra ser monitor, a gente contrata. Se não tem aí tem que buscar no mercado. Aí tem seleção.

Analisando o papel dos monitores no processo de trabalho do NOT, podemos considerá-lo como um trabalhador responsável pela execução de algumas atividades planejadas pelo coordenador da oficina.

Nesse aspecto, identificamos no processo de trabalho do NOT a existência da divisão parcelar do trabalho em saúde, refletidas, por sua vez, nas relações hierárquicas de comando, que ocorrem quando o profissional de nível superior, que detém o poder e os conhecimentos relativos ao planejamento do trabalho, delega tarefas específicas aos trabalhadores de nível médio ou elementar, referidas à execução desse projeto, configurando, portanto, uma divisão do trabalho (Pires, 2008), conforme os fragmentos abaixo:

E8.56 - o coordenador ele fica mais na infra-estrutura, quando tem tempo também, senão o coordenador também vai pra produção, pra cuidar do material, compra de material, estratégia mesmo pra distribuir atividade, quem começa primeiro, como que vai se dá a produção, e o monitor está junto, o tempo todo circulando, tirando duvida, orientando, ensinando.

E6.2 - Então, todo o cuidado com os oficineiros, compra de material, ligar pras equipes, pras famílias, e fazer o contato assim com as equipes da rede também que estão atendendo as pessoas, pesquisa de mercado, de produtos novos, então é uma rede de atividades, fora as reuniões de equipe, planejamento, evolução de prontuário, então tem uma série de atividades que o coordenador faz. 
Inicialmente, o processo de trabalho em saúde podia ser desempenhado em cada unidade por um único trabalhador, o médico, que se encarregava tanto do diagnóstico (discriminação de algumas qualidades da natureza que permite um projeto sob a forma de objeto de trabalho), quanto da terapêutica (ação transformadora do objeto de trabalho em produto), uma vez que o instrumental utilizado nessas duas fases (instrumentos de trabalho) era escasso o suficiente para o médico poder carregá-lo consigo. Entretanto, como todo o trabalho humano, o trabalho médico também pode ser separado em seu momento de projeto e de execução, em trabalho intelectual e trabalho manual; divisão concebida, na concepção marxista, como divisão social do trabalho.

Embora, como afirmado acima, o trabalho médico tenha sido parcelado em outras práticas de saúde, como a enfermagem, psicologia, terapia ocupacional, serviço social, o que atualmente definimos como trabalho em equipe, desde então prevalece no imaginário coletivo a idéia de que a responsabilidade pelas intervenções de saúde seja fundamentalmente do profissional médico. Não por acaso, na perspectiva clínica positivista, este profissional permanece com o domínio da concepção e execução do trabalho em saúde, que se pode constatar entre outras evidências pela diferença salarial e de status da categoria médica em relação aos demais trabalhadores da saúde (Gonçalves, 1992).

De qualquer maneira, este parcelamento do trabalho em saúde também resultou na criação de distintos serviços de saúde, que teriam responsabilidades específicas em relação à saúde da população, recortando o seu objeto (as necessidades de saúde do ser humano) e desenvolvendo intervenções cada vez mais especializadas (instrumentos) para atingir resultados específicos (finalidade) por meio das chamadas especialidades.

O aumento das especialidades na área da saúde, apesar de ficar mais visível em relação ao trabalho médico, ocorre, também, com os demais profissionais de saúde. A especialização do conhecimento e do trabalho em saúde resulta do fenômeno da especialização do conhecimento humano, mas resulta, também, da concepção positivista da ciência e da fragmentação do trabalho (Pires, 2008, p.172).

Logo, a organização dos serviços de saúde segue a lógica da especialidade, que corresponde à lógica da fragmentação, do parcelamento 
do homem, característico do modelo biológico positivista do processo de saúde e doença, na qual as funções mais intelectuais estão sob o domínio dos especialistas e as mais manuais ficaram a cargo dos técnicos de nível inferior ou trabalhadores sem formação específica (Pires, 2008).

A divisão do trabalho caracterizou o processo de produção capitalista conhecido por manufatura, que predominou o modo de produção do período compreendido entre o século XVI e o século XVIII. Sua importância na evolução da organização do trabalho foi a transformação da cooperação entre os ofícios, realizados pelos trabalhadores em toda extensão no modo de produção artesanal, para uma espécie particular de cooperação onde se redistribuiu o trabalho em operações independentes, parciais, paralelas, executadas simultaneamente por muitos trabalhadores, concentrados no mesmo espaço, com o propósito de aumentar a produtividade do trabalho pela repetição e redução do tempo de produção, eliminando as lacunas entre as operação (Marx, s/d).

$\mathrm{Na}$ manufatura, entretanto, a execução das operações parciais dependia, todavia, da força, da habilidade, da rapidez e da segurança do trabalhador individual ao manejar seu instrumento. Essas diferentes qualidades do trabalhador, por sua vez, exigiam diferentes graus de formação, possuindo consequentemente valores diferenciados. À essa hierarquização nas forças de trabalho correspondeu a introdução da escala de salários (Marx, s/d).

Como conseqüência, a divisão manufatureira do trabalho introduziu na história dos modos de produção a concentração dos meios de produção nas mãos de um capitalista, a divisão social e técnica do trabalho, a condenação do trabalhador a executar perpetuamente uma operação parcial e sua subordinação a uma autoridade, criando também uma graduação hierárquica entre os próprios trabalhadores.

A divisão manufatureira do trabalho por meio da decomposição do ofício manual, da especialização das ferramentas, da formação dos trabalhadores parciais, agrupados e combinados num mecanismo único, criou a subdivisão qualitativa e a proporcionalidade quantitativa dos processos sociais de produção; criando determinada organização do 
trabalho social e desenvolvendo ao mesmo tempo nova força produtiva social do trabalho (Marx, s/d).

A divisão manufatureira do trabalho, nas bases históricas dadas, só poderia surgir sob forma especificamente capitalista. Como forma capitalista do processo social de produção, é apenas um método especial de produzir mais valia relativa ou de expandir o valor do capital, o que se chama de riqueza social, "Wealth of Nations" etc., as custas do trabalhador. Ela desenvolve a força produtiva do trabalho coletivo para o capitalista e não para o trabalhador e, além disso, deforma o trabalhador individual. Produz novas condições de domínio do capital sobre o trabalho. Revela-se, de um lado, progresso histórico e fator necessário do desenvolvimento econômico da sociedade, e, do outro, meio civilizado e refinado de exploração (p. 417-8).

O fenômeno da divisão social do trabalho não se limitou ao modo de produção material (produtivo), mas alargou-se para todas as formas de produção social, além disso, os efeitos dessa organização do trabalho social geraram um aumento no custo da reprodução da força de trabalho, evidenciado pelas reivindicações trabalhistas, tendo como conseqüência a socialização desses custos, especialmente com o Estado (Pires, 2008).

Com o Welfare State, o Estado passou a responsabilizar-se pela assistência dos trabalhadores e suas famílias, de maneira a reduzir os custos com a reprodução da força de trabalho pelo capital, inclusive evitando o aprofundamento da luta de classes e promovendo um pacto entre capital e trabalho, fundamental à manutenção do sistema capitalista.

O processo de trabalho na oficina, diferentemente do processo de trabalho em saúde, se caracteriza por ser um processo de produção de mercadorias, destinadas à comercialização para geração de renda, que, ao final desse processo, será distribuída entre os oficineiros.

Nas oficinas a renda é gerada através dos produtos e da prestação de serviços. Estes propiciam aos oficineiros remuneração mensal, chamada bolsa-oficina, que é definida pelos resultados econômicos (entradas e saídas) e por critérios de avaliação de função, de desempenho, de freqüência, responsabilização do oficineiro com seu tratamento, entre outros (Alcântara, 2007, p. 169).

Portanto, o processo de trabalho da oficina não pode ser considerado um processo de produção de mais valia, que reproduz a acumulação do capital à custa da exploração da força de trabalho. Entretanto, pela sua forma de organização, embora assemelhada ao modo de produção artesanal, pode reproduzir uma divisão do trabalho, como na manufatura, 
que acaba por gerar alienação e subordinação, evidentemente, em níveis menores do que no chamado mercado de trabalho formal.

Como vimos, na divisão de tarefas cabe ao coordenador a responsabilidade pelo planejamento e pelo controle do processo de produção juntamente com o monitor, que o auxilia na elaboração e execução das atividades administrativas e comerciais, sendo responsável pelo acompanhamento dos oficineiros na produção. Ao oficineiro, finalmente, cabe à execução das tarefas determinadas pelo coordenador e pelo monitor, de acordo com sua função no processo de produção da oficina.

E9.1 - Lá eu trabalho com as atividades de decoração, de produção, criação de peças, pra decoração e utilitários também de festas, e também prestação de serviços.

E1.113 - Então a gente busca cursos tanto pro monitor quanto pro coordenador que são profissionais que nem sempre tem uma formação específica. Hoje a gente tem algumas oficinas que tem tipo serralheria tem um soldador, marcenaria tem um marceneiro, que são pessoas que já são dessa área.

E1.125 - E tem oficineiro, por exemplo, alguns grupos da agrícola, eles fazem uma tarefa, como por exemplo, os grupos que estão no condomínio, que não tem o monitor junto. Então, é um oficineiro que está nessa função de estar junto com o grupo, e ele é o que responde ali pela tarefa, pelo grupo. Ele está em contato.

E3.45 - Então hoje nós temos o mosaicista um, dois e três. Nós temos o rejuntador, que é aquele que faz o acabamento do rejunto, do mosaico, e o que eu ainda não tenho, que eles não gostam, é da pintura. A pintura final, a pintura de acabamento.

E2.41 - Então nós somos em quatro e mais dezoito oficineiros, mas eles trabalham bem ativos na produção, porque a gente depende deles.

Essas funções são determinadas segundo a habilidade do oficineiro na execução da atividade, que inicialmente, como já vimos, será testado nas diversas etapas da produção, começando pelas atividades consideradas mais simples e mais fáceis de executar:

E10.45 - então a gente vai dividindo de acordo com, com o que cada um sabe fazer...

E2.38 - Então eles fazem..., é, depende da habilidade, tudo, então desde a lavagem de louça, picar, fazer arroz, ajudar, fazer limpeza, faxina, trabalhar no estoque de alimentos, ajudar a organizar, olhar validade, tudo isso, servir no restaurante, limpar mesa, tudo isso eles fazem, picar verdura, lavar verdura, arrumar sobremesa, tudo.

E3.69 - E aí é distribuído de acordo com a habilidade de cada um, o que esse vai fazer se é mais complexo, o que aquele vai fazer é 
menos complexo, e assim por diante. Então é o monitor que acompanha essa parte, mas quando eu estou sem o monitor é o coordenador.

E6.42 - ela é boa no acabamento, às vezes ela acaba ficando mais pro acabamento, ou se ela consegue ajudar na organização da oficina, outras atividades que a gente precisa, a gente vai adaptando também.

E5.14 - Geralmente começam pelas atividades mais rudimentares, que não exigem muita habilidade e concentração, e depois são encaminhados para as atividades que exigem maior habilidade $e$ também muita concentração.

E4.22 (funções) - Então é: auxiliar de agricultor um, auxiliar de agricultor dois, auxiliar de agricultor três e agricultor. Então ele inicia no três pra ir começando a se adaptar a atividade.

A divisão técnica do trabalho não se constitui por si só numa divisão social do trabalho, uma vez que apenas a distribuição de tarefas para racionalizar e qualificar o processo de produção, não caracteriza a divisão social do trabalho, na qual o trabalhador está condenado à execução de uma operação parcial, desconhecendo e alienando-se do processo de produção em sua extensão, o que resulta na desqualificação e na desvalorização de sua força de trabalho expressa na forma de salário ou remuneração.

E3.47 - Porque nós colocamos, eles são testados em qual atividade se adaptam mais, e é o mosaico que eles querem, por quê?

E3.48 - Porque é o mosaicista que ganha mais! Então eu vou ter que estar repensando o salário do pintor, pra segurar o pintor lá.

E5.30 - Quem vai pra máquina, com certeza tem uma avaliação melhor do que o que apenas consegue varrer, lavar o banheiro, por exemplo.

E5.31 - Até mesmo porque quem executa esse trabalho é o que vai gerar a renda pra oficina. Então as pessoas que vão construir os trabalhos, e que o dinheiro vem através deles, então tem sim essa diferença.

E3.50 (diferença no valor da bolsa) - Porque é um trabalho muito elaborado, porque imagina fazer pétala por pétala de uma flor. $E$ aquele capricho, e combinar cores. Tudo isso leva em conta.

Entretanto, este parcelamento do trabalho pode ser amortizado pela profissionalização, objetivo identificado pelo NOT. Nesse sentido, o processo de produção na oficina pode ser considerado um instrumento que objetiva a aprendizagem de conhecimentos e habilidades ocupacionais por meio do treinamento, do qual participam também os demais oficineiros: 
E3.44 - então nós temos as funções dos mosaicistas, e essa função, ele começa primeiro pintando uma peça, a parte branca, depois ele começa a aprender o manuseio da turquesa, então ele vai sendo treinado.

E3.46 - Essa parte (a pintura) ainda estou captando quem é que vai um dia gostar e será treinado sempre pra fazer essa parte.

E5.15 - Depois conforme a gente vai avaliando o grau de desenvoltura, de concentração, e se eles não apresentam riscos nas máquinas, a gente vai proporcionando que eles aprendam a mexer com as mesmas...

E10.7 - A gente vai ensinando aos poucos, conforme o pessoal vai entrando na oficina vai levando para eventos, pra ele eles aprenderem, eles trabalham como garçom também.

E10.21 - é muito difícil a gente achar na triagem uma pessoa assim, na verdade com o trabalho da oficina que normalmente eles vão aprendendo...

E5.39 - Os mais velhos vão ensinando os mais novos, que não pode desperdiçar que tem que tomar cuidado com o material.

Como vimos, a divisão do trabalho nas oficinas do NOT é a mesma que vigora no contexto da produção social, cuja fragmentação do trabalho é responsável pela alienação e reprodução da ideologia dominante e suas relações de poder e domínio sobretudo efetivado no interior da produção. No campo da saúde, tanto a fragmentação do paciente e da própria subjetividade como do processo de trabalho (trabalho intelectual e decisório versus trabalho de execução, separação entre momento diagnóstico e momento terapêutico) são alguns dos modos de expropriação, tanto de trabalhadores quanto de usuários, do excedente preciso, equivalente da "mais-valia" no contexto das práticas em saúde mental. "Ou seja, onde há muita reprodução há pouca produção; onde há subjetividade serializada falta subjetividade singularizada" (Costa-Rosa, Luzio, Yasui, 2001, p. 22).

\subsection{Organização do Trabalho nas Oficinas}

O setor de serviços, onde se localiza o setor saúde, também foi e é profundamente influenciado pela lógica de acumulação de capital, pela tecnologia e pelas formas de organização do trabalho que foram inicialmente 
desenvolvidas pela indústria, baseadas na divisão social do trabalho ${ }^{27}$ : fordismo, taylorismo, ou toyotismo. (Pires, 2008).

Logo, a organização da estrutura assistencial institucional em saúde é resultado do processo histórico sobre: o modo de entender o processo saúde-doença, em cada sociedade, e a conseqüente organização da assistência; o modo de produzir saúde, influenciado pelo modo hegemônico de produção e organização do trabalho social, em cada época; a evolução dos conhecimentos científicos e das suas tecnologias; o papel do Estado na saúde e nas relações de trabalho; a organização dos trabalhadores e sua capacidade em intervir nas decisões políticas, especialmente com relação à saúde (Pires, 2008).

Nesse sentido, a análise do processo de trabalho em saúde deve necessariamente considerar a forma de organização dessa produção, que como vimos, é influenciada pelas formas hegemônicas de organização do trabalho social, que não se configuram apenas como maneiras eficientes de organizar o trabalho coletivo, mas acabam por reproduzir as relações sociais dominantes na ordem capitalista que se caracterizam, entre outros aspectos, pela alienação, pela exploração e pelo estranhamento decorrentes das relações sociais de produção, em especial da divisão social do trabalho.

O parcelamento do trabalho na instituição analisada torna-se mais evidente quando se analisa o processo de trabalho no interior da oficina, do qual participam o coordenador, o(s) monitor(es) e os oficineiros.

Essa organização do processo de produção na oficina baseada na divisão de tarefas, diferenciadas por níveis de complexidade, demonstra uma semelhança com a forma de organização do trabalho conhecida por fordismo, que, essencialmente, organiza-se sob o formato de linha de montagem:

E3.71 (produção) - Peça por peça. É lógico que tem uma pessoa que faz o acabamento final, que vai fazendo a limpeza da peça, vai embalando.

E5.21 (funções) - Tem auxiliar de monitor, que é o que trabalha ligado ao monitor e que vai pras máquinas. Tem os que ficam lixando, que trabalham nas lixadeiras e tem os que trabalham na pintura, que é de envernizar, pintar, trocar as faixinhas, e tem os

${ }^{27}$ A esse respeito ver Antunes (1999). 
que executam os trabalhos de limpeza e office-boy, que vão tirar xérox, vão levar um pedido, de certa forma são os mais comprometidos da oficina.

E2.45 (avaliação) - eles são separados em: ajudante 1, que é o pessoal que domina mais o fogão, ajudante 2 que ajuda no prépreparo, picar, e o pessoal do 3 já é mais assim, lavagem de louça, faxina, essas coisas. Então eles têm uma classificação diferente pra avaliação.

Outra forma de organização do trabalho, hegemônica do modo de produção capitalista, encontrada no processo de produção da oficina trata-se do chamado taylorismo, que se fundamenta na separação entre 0 controle/planejamento, responsabilidade do coordenador, auxiliado pelo monitor; da execução do trabalho, função dos oficineiros sob o comando do monitor e do coordenador, conforme depreendido nos discursos:

E3.68 - O monitor desenha, faz o desenho pro mosaico e escreve as cores que vão ser usadas.

E3.70 - vamos imaginar que recebemos um pedido que o cliente pede pra gente criar. Então sentamos eu e a monitora e pensamos: então, vamos fazer essa mesa com esse desenho. Ah, ele pediu varias coisas diferentes, são dez mesas, então vamos pensar em dez modelos diferentes e aí já escolhemos, e ela vai desenhando e vai distribuindo. Quando um termina o outro desenho já está pronto e assim por diante.

E4.33 (definição do preço) - Nós fazemos o seguinte: a pessoa liga, solicita o serviço, eu vou junto com o monitor ou o monitor vai sozinho, faz um orçamento, daí ele traz pra gente, aí senta eu e ele e a gente fecha o valor.

E4.2 (atividades comerciais) - ... eu tenho que estar trabalhando junto com a questão de venda do nosso serviço, a prestação, estar fechando os contratos com o condomínio referente ao serviço de jardinagem.

E8.10 - Administrativa e produtiva, então o coordenador é responsável pela compra, pela elaboração do produto, tem que buscar a técnica desenvolvida e aplicar na oficina, composição de preço do produto, pensar estratégias de como colocar esse produto no mercado, não necessariamente eu vou colocar, fazer a venda, mas pensar como eu vou colocar. Dei uma resumida isso na parte produtiva.

E10.2 - eu desenvolvo desde a parte da nutricionista mesmo, que é a parte de elaboração de cardápio, custo, orçamento, treinamento aqui pro meu pessoal, na parte de manipulação, higiene, conservação, então tudo que está voltado pro alimento eu faço na oficina...

Essa hierarquização do trabalho pode ser constatada também pelo número de trabalhadores responsáveis por cada função: restrito nas funções 
mais intelectualizadas relacionadas ao planejamento e ao controle do processo de trabalho; e ampliado para as funções mais operacionais e manuais, relativas à execução do trabalho, conforme as frases abaixo:

E2.39 - São 18 vagas na oficina, eu tenho três monitores, tenho um monitor que é cozinheiro, então ele coordena a parte da preparação, tudo.

E4.16 (capacidade da oficina) - Nós temos: são seis monitores, uma auxiliar administrativa, eu como coordenadora, e tem sessenta e três pacientes. Na verdade são cinqüenta vagas e nós temos mais as vagas excedentes.

E5.41 - Hoje eu estou com vaga sobrando. Mas é pra ter dezoito oficineiros, e eu tenho dois monitores.

E7.65 - São quinze vagas e um monitor. Mas às vezes não necessariamente eu tenho quinze pessoas, porque às vezes eu tenho dezoito...

O controle do processo de produção na oficina, portanto, é uma das responsabilidades do coordenador (auxiliado pelo monitor), que se configura também pelo acompanhamento do oficineiro na execução das tarefas e pela avaliação do seu desempenho na produção:

E11.4 - umas das principais mesmo é você fazer o acompanhamento, desse oficineiro dentro da oficina em todas as etapas dele, o inicio dele, depois quando ele está mais vinculado com o grupo e depois manter esse acompanhamento, que seriam as coisas principais...

E11.3 - dentro da oficina a gente vê toda a parte também da produção dela, como que está desenvolvendo a atividade, se está fazendo legal, se não está, se está com alguma dificuldade.

E9.18 - E essa bancada, o pessoal fica sentado ali mesmo, cuidando uns dos outros, sendo cuidados e sob o olhar do coordenador e monitor.

E1.171- E depois dessa primeira apresentação, a gente acompanha o desempenho e vai avaliando como é que está na atividade, vai acompanhando a inclusão no grupo, as relações, enfim, aí já está incluído na oficina.

De maneira sintética, o binômio fordismo/taylorismo, expressão dominante do sistema produtivo e de seu respectivo processo de trabalho, que vigorou na grande indústria, principalmente ao longo do século $X X$, baseava-se na produção homogeneizada e verticalizada, que pretendia racionalizar ao máximo as operações realizadas pelos trabalhadores, reduzindo o tempo e aumentando o ritmo de trabalho, intensificando, portanto, as formas de exploração. Estruturado no trabalho parcelar e 
fragmentado, na decomposição das tarefas, esse processo de desantropomorfização do trabalho possibilitou a extensão da extração da mais valia pelo prolongamento da jornada de trabalho.

Para o capital, tratava-se de apropriar-se do savoir faire do trabalho, "suprimindo" a dimensão intelectual do trabalho operário, que era transferida para as esferas de gerência científica. A atividade de trabalho reduzia-se a uma ação mecânica e repetitiva (Antunes, 1999, p. 37).

O taylorismo/fordismo, portanto, realizava uma expropriação intensificada do chamado operário-massa, destituindo-o de qualquer participação do processo de trabalho, reduzindo-se a uma atividade repetitiva e desprovida de sentido, uma atividade alienada. Ao mesmo tempo, esse operário-massa era frequentemente chamado a corrigir deformações e equívocos cometidos pelos quadros gerenciais e administrativos, caracterizando uma contradição entre autonomia e heteronomia, próprias desse processo de trabalho, acrescida da contradição entre produção e consumo (Antunes, 1999).

Consequentemente, as lutas operárias que se levantaram contra esses modelos, defendiam a auto-organização do coletivo de trabalhadores, resgatando as virtudes emancipatórias da auto-atividade dos trabalhadores. O que estava em jogo era a possibilidade efetiva do controle social dos trabalhadores dos meios materiais do processo produtivo, a possibilidade concreta de controle social do trabalho sem o capital. A derrota da luta operária pelo controle social da produção, abriu caminho para a retomada do processo de reestruturação produtiva (toyotismo), mantendo a multiplicação dos lucros capitalistas pela exploração não apenas da força braçal, mas da imaginação, dos dotes organizativos, da capacidade de cooperação e da inteligência dos trabalhadores (Antunes, 1999).

Trazendo essa discussão para o campo da saúde, a necessidade de superação desses processos de trabalho que alienam tanto os trabalhadores em saúde quanto os usuários pressupõe a organização de novos modos de produção pautados na auto-gestão. No caso do NOT, constatamos uma contradição no que diz respeito à essa possibilidade, aparentemente permitida aos profissionais da equipe técnica (coordenadores) contudo dificultada no caso dos monitores e oficineiros. Além disso, essa forma de 
organização também é responsável pela manutenção das relações de poder, similar à estrutura social, quando o domínio do controle da produção fica centralizado nas funções gerenciais e administrativas, retirando do trabalhador (seja profissionais ou usuários) sua capacidade criativa e intelectual, especialmente de emancipação.

A avaliação de desempenho, que segundo os entrevistados, é baseada em critérios como habilidade, assiduidade, pontualidade, envolvimento, relacionamento adequado com o grupo, respeito às regras, também corrobora com essa hierarquização do trabalho, resultando numa classificação e numa pontuação que define tanto o valor da bolsa quanto a função do oficineiro na oficina e também sua passagem ou não para uma função superior, cujo valor da remuneração (bolsa-trabalho) é maior. Essa avaliação é realizada durante as chamadas "rodas de conversa", podendo ser organizadas individualmente ou em grupo, a depender da escolha do grupo de produção:

E3.55 - Na avaliação é avaliado o todo. Então é o interesse, é a permanência...

E3.59 - E o grupo já está treinado pra essa avaliação, ele capta, ele sabe aquele que está interessado, fica muito estampado, aquele que tem interesse, que pertence ao grupo e cuida do grupo pro grupo ter o bônus melhor no fim do mês.

E2.52 (processo de avaliação) - Então eu sento com os monitores, e aí a gente tem uma tabelinha, que é assiduidade, pontualidade, higiene, se critica os colegas, se empenha na atividade, várias, e a gente vai pontuando e depois dentro da classificação a gente coloca as porcentagens.

E2.53 - Aí tem uma planilha que tem o nome de cada um a gente coloca as horas, a porcentagem calcula o que cada um vai receber.

E3.58 - O período em que nós temos produção maior, que tem que entregar produto às vezes depois do trabalho, que é às 6 horas. Porque normalmente é das oito as dezesseis, mas às vezes tem que ficar até as dezoito horas.Ou finais de semana, então aquele que vem, ou aquele que falta. Então são coisas que vão entrando na avaliação.

A mudança de funções no interior do processo de trabalho na oficina, que resulta num aumento do valor da bolsa, também está condicionada à esse processo de avaliação:

E3.52 (processo de avaliação) - E a avaliação pra passar de uma função pra outra também, é o grupo que ajuda a avaliar. 
E3.53 - É lógico que a gente vai coordenando essa discussão, mas eles vêem o trabalho de cada um, e o esforço de cada um pra crescer dentro da oficina.

E3.57- Então pra ele passar de uma função para outra além dele demonstrar a habilidade real no trabalho terminado, é considerado também o respeito no grupo, o respeito pelo monitor, enfim, as regras da oficina.

E4.23 (processo de avaliação) - aí a gente senta, eu e os monitores, a gente faz uma avaliação ele vai pra uma outra função.

E6.40 (mudança de função)- Isso vai aumentando a porcentagem da bolsa que eles recebem.

E8.58 (funções na oficina) - ...mas variação, mudança de funções não tem muito não, só nos níveis, então a gente faz essa avaliação...

$\mathrm{Na}$ percepção de alguns dos entrevistados, os oficineiros preferem que essa avaliação de desempenho seja realizada individualmente com o coordenador e o monitor da oficina, evidenciando uma reprodução da ideologia e da hierarquia social do trabalho, conforme depreendido das frases abaixo:

E2.49 - E eles não querem ser avaliados, porque um não quer entrar em confronto com o outro.

E2.51 - Então já colocamos várias vezes em votação, discussão essa coisa da avaliação e eles querem que a gente avalie.

E4.70 (avaliação) - Mas eu percebi que tinham algumas pessoas ficavam um pouco inibidas, outras não estavam gostando, às vezes da gente estar pontuando alguma coisa que não foi legal ou até mesmo elogiar um e o outro se sentia ofendido.

E4.72 (processo de avaliação) - E a outra é um momento que eu estou fazendo com o monitor, e quando é necessário, a gente chama a pessoa e conversa, ou pra dar um toque que melhorou, ou pra dar um toque de que ela precisa se empenhar mais.

E5.35 - Porque quando você fala em avaliação, é uma coisa muito pesada, parece que você vai lá pra julgar o outro, avaliar, e quando você fala que é uma roda de conversa ameniza um pouco, então eles tem mais liberdade de estar falando, de estar conversando.

Embora exista a figura de um coordenador e de monitores, para Alcântara (2007), as decisões sobre a produção são feitas democraticamente, respeitando as decisões e opiniões dos participantes durante as "rodas de conversa", que são realizadas em dois momentos com propósitos distintos: avaliação de desempenho e organização da produção, conforme frases abaixo: 
E3.51 (diferença no valor da bolsa) - Isso é construído com eles.

E4.71 (processo de avaliação) - Então a gente está fazendo em dois momentos: o primeiro momento é essa roda, essa conversa, que daí a gente, também vai ta conversando um pouco, e querendo saber se está tudo bem pra eles, como está acontecendo, se eles precisam de alguma coisa pra melhorar, se eles têm alguma coisa pra elogiar do serviço.

E8.57 - nós fazemos rodas de discussão sobre o serviço e de avaliação. De avaliação bem menos, a gente tem feito rodas porque é um grupo que ta estável, não tem muita variação...

E8.60 - É pelo menos duas rodas pra gente falar de assuntos da oficina, e outras da avaliação, mas a gente tem várias outras atividades de lazer, comemorar aniversariantes do mês.

Essas "rodas de conversa", portanto, além da avaliação de desempenho, tem por finalidade discutir coletivamente questões sobre a organização da produção, geralmente relacionadas à identificação de dificuldades, à elaboração de soluções, à solicitação de materiais e ferramentas, à avaliação da produção, ao controle de qualidade, à necessidade de manutenção ou investimento no maquinário, e ainda ao planejamento de atividades de convivência e lazer:

E4.74 - praticamente todo dia de manhã, no café da manhã, a gente tem uma roda, que é onde a gente conversa, onde eles pedem, solicitam material, ferramentas, acompanhamento, mas daí todo dia de manhã tem essa conversa.

E6.58- E da gente ter esses espaços da rodas também que a gente sempre conversa o que está legal e o que não está na oficina, o que a gente pode melhorar, se aconteceu alguma coisa que alguém gostaria de colocar pra gente resolver em grupo, então eu acho que essa é uma possibilidade muito legal...

E5.37 - Então é o momento que a gente meio que, limpa os caminhos e organiza o meio, sempre buscando o que é melhor pra oficina, o que a gente está fazendo, o que a gente pode estar desenvolvendo mais.

E8.59 - ...essa roda de avaliação mensal e de serviço também mensal pra discutir: o quê a gente precisa investir, que maquinário, o quê está faltando, aonde que está o problema, que problema é, e às vezes a gente resolve fazer passeios, em churrascarias, é tudo nessas rodas que a gente discute.

E1.104 - Aí as pautas são inúmeras. Às vezes é porque estamos sem trabalho, não chegou material, ah tem pouco encomenda, como vamos fazer, como combina a visita para fazer pesquisa de mercado, ou se a gente está com pouco serviço e o pessoal diz ah o que a gente pode fazer, vamos divulgar mais a oficina. É onde aparecem as dificuldades, pensa-se nas soluções $e$ encaminhamentos. 
Embora as rodas de conversa possibilitem a reflexão coletiva de questões referentes à organização do trabalho, estas parecem não ser percebidas pelos oficineiros como momentos de decisão coletiva acerca do processo de trabalho, visto que, muitas vezes, identificam a figura do coordenador ou do monitor como um superior hierárquico representado pela figura do patrão, segundo frases abaixo:

E1.127- Eu acho que tem mais assim, o respeito pelo monitor, pelo coordenador, assim, a gente procura não estar nesse papel hierárquico assim, de ser chefe, nem de tomar decisão sem comunicar o grupo, mas acaba que tem, não dá pra dizer que não tem.

E1.189 - então esse trabalho é cansativo assim, do coordenador de estar o tempo todo, porque o tempo todo você fica no lugar do patrão às vezes, então é cotidiano assim você ter que lidar com isso. E eles demandam do coordenador, às vezes na figura do monitor, tem um usuário da oficina que fala: ah, meu patrão.

E1.108 - Tem este movimento, muitas vezes de queixa: Ah a gente ganha muito pouco, que a bolsa está muita baixa, sempre trazendo... Aí é nosso papel de devolver, porque tem uma coisa de achar que o monitor e o coordenador são os patrões e é o chefe e é ele que vai ter que resolver.

Tal fato, portanto, deve-se tanto à forma de organização do trabalho na oficina, conforme analisamos anteriormente, quanto da ideologia dominante que estabelece determinadas relações sociais de trabalho (divisão e hierarquização do trabalho), responsáveis pela alienação e subordinação da classe trabalhadora, que embora de aparências distintas, são reproduzidas também no trabalho em saúde:

Convém não perdermos de vista que a natureza desse excedente muda conforme o seu destinatário. Num caso dá-se como reprodução das relações sociais dominantes (subjetividade capitalista), no outro dá-se como recriação de relações sociais em sintonia com o agenciamento dos interesses sociais subordinados (intersubjetividade horizontal singularizada) (Costa-Rosa, Luzio, Yasui, 2001, p. 22).

Logo, a transformação da assistência em saúde mental, assim como outros modos de produção social, que objetivam a emancipação dos trabalhadores (operadores e usuários) pressupõe, portanto, a superação teórica-técnica e ideológica do modelo fordismo/taylorismo no processo de trabalho na saúde mental, e sua substituição por outro modo capaz de permitir que o produto mais precioso do processo de trabalho (a implicação 
subjetiva e a singularização) seja apropriado pelos trabalhadores e pelos usuários e posto a seu serviço, em contraposição ao Modo Asilar, na qual é o intermediário, dono dos meios de produção e das decisões do quê e como produzir, quem se apropria do produto do trabalho (Costa-Rosa, Luzio, Yasui, 2001).

A preocupação com o controle da qualidade e com o atendimento da demanda de produção, sob a forma de encomendas, constitui-se também em ponto de pauta dessas assembléias. Esses dois aspectos da produção controle de qualidade e aumento da produtividade - são apontados como dois instrumentos utilizados no processo de produção de mercadoria (valores de troca), cuja finalidade é a obtenção de recursos por meio da comercialização desses produtos, que serão transformados em renda revertida aos oficineiros.

\subsection{Finalidade do processo de trabalho nas oficinas: Produção de} Mercadorias e Prestação de Serviços para Geração de Renda

Como vimos, o produto do processo de trabalho nas oficinas é a mercadoria ou a prestação de serviços, cuja finalidade não é a obtenção de mais valia como na forma de produção capitalista, mas a sua transformação em valores de troca (renda), dividida entre os oficineiros participantes, destinadas às suas necessidades, em sua maioria, à aquisição de valores de uso:

\footnotetext{
O valor da bolsa-oficina é variável. Pode atingir, de acordo, com a receita mensal de cada oficina, valores que variam entre $R \$ 30,00$ e $\mathrm{R} \$ 500,00$ por oficineiro. Sobre o uso da renda mensal obtida, a equipe do NOT fez um breve levantamento junto aos grupos e identificou que: para $36 \%$ dos oficineiros o dinheiro da bolsa é destinado a ajudar a família e à manutenção da casa (alimentação, $21,1 \%$, e pagamento de contas diversas, $21 \%$ ), além de ser usado com vestuário (34\%) e outros bens de consumo próprio (25\%) (Alcântara, 2007, p. 169).
}

Portanto, a produção de mercadorias em quantidade suficiente e qualidade adequada à comercialização, à prestação de serviços e ao atendimento satisfatório dos clientes é identificada pelos discursos como uma preocupação de todos os participantes da oficina de trabalho, 
especialmente com relação à qualidade adequada às exigências do mercado de consumo:

E2.24 - E a gente precisa qualificar o serviço, porque cada vez a procura é maior por um produto mais bem feito, mais bem acabado, ou personalizado.

E4.28 - eles ficam na oficina e aí vem também a questão da nossa qualidade do nosso serviço, porque eles ajudam e muito, na nossa qualidade, no nosso serviço...

E5.54 - Eles aprenderam que se eles não compram uma peça a outra pessoa também não compra. Então, assim, eles prezam muito pela qualidade do produto.

E5.56 - Então eles conseguem ter essa visão de mercado, que antigamente não tinham. Então assim: ah, vamos fazer por fazer. Hoje não. Hoje eles próprios são gerenciadores da qualidade do produto.

Essa necessidade de qualificação dos produtos, traduzida na transformação do processo de produção, se justifica não apenas pela comercialização, mas também, segundo os entrevistados, pela valorização da capacidade produtiva dos usuários, visando uma transformação cultural na qual as peças confeccionadas não sejam compradas por caridade, fato considerado como uma desqualificação. Essa mudança cultural é identificada como um resultado positivo da produção nas oficinas, objetivada em produtos considerados belos e úteis.

E5.63 - Muitas reuniões, muita conversa. Individualmente conversando com alguns, que ficam à frente de determinadas atividades, assim, não foi um trabalho muito fácil. Foi um trabalho que demandou uns dois anos, pelo menos, assim, de mudar todo um processo de trabalho de mentalidade.

E5.66 - Mas é uma coisa introjetada do mercado, sabe, eu acho que isso é o grande destino das oficinas de geração de renda. Não é você comprar essa caixinha porque: ai que dó, o cara que fez tem problemas. Mas é você sentir prazer em comprar aquilo, e ter na sua casa e dizer: olha, paguei lá trinta reais, mas que lindo. Eu acho que isso que vale a pena, então acho que foi um grande divisor da oficina.

E11.42 - E a gente não usa tipo a campanha apelativa assim: ah compre os nossos produtos, porque são de pessoas com problemas mentais, a gente nunca usou disso, nunca quisemos.

E11.43 - Então a gente sempre optou pela boa mercadoria, de mostrar uma boa mercadoria, que eles tem capacidade de estar confeccionando e tudo mais. 
E5.53 - É um produto que, as pessoas não compram por que foi um doido que fez. Mas sim porque tem qualidade, tem preço, tem bom gosto.

A produtividade das oficinas também é considerada um elemento importante do processo de produção, visto que com o crescimento do serviço especialmente após a criação da loja Armazém das Oficinas em termos de divulgação dos produtos e ampliação da clientela, tornou-se necessário aumentar a produtividade e diversificar a produção, conforme frases abaixo:

E5.43 - Então a gente foi mudando todo o processo da oficina.

E6.44 - estão vendo possibilidades pra melhorar no mercado, mas é uma dificuldade também. Porque às vezes se vem um pedido muito grande às vezes gente não dá conta. Não que não dê conta, mas aí precisa trabalhar mais, aumentar o ritmo, ou se vem pouco coisa é difícil também.

E5.45 - a gente conseguiu assim ampliar muito essa gama de variedade, então assim, além dos objetos de decoração que a gente trabalha com cipó, bambu, e outro materiais, a gente conseguiu fazer uma linha diferente, uma linha grande, que é onde que dá o dinheiro, que é onde a gente pode cobrar o valor da peça e ganhar...

Portanto, a organização da produção nas oficinas está relacionada ao atendimento dos pedidos e das encomendas e ao abastecimento da loja Armazém das Oficinas, que, entretanto, não configura uma demanda fixa, uma vez que é determinada pela flutuação do mercado de consumo.

E3.40 - Então nossa produção é para atender pedidos.

E3.41 - Sob encomenda. E também para abastecer a nossa loja, atender nossos clientes da loja, então são duas fontes aí que gera produção pro ano inteiro...

E5.68 - A gente tem a loja, tem alguns clientes que vem na oficina, têm as oficinas que pedem o trabalho, a gente recebe pedido pela internet. Então, assim, raramente o dia que não chega um orçamento ou um pedido.

E5.49 - E hoje em dia a gente pega muito brinde pra fazer. Então a gente vende pra UNILEVER, pra $3 M$, pra algumas empresas de publicidade.

E6.47 - É eu acho que a gente ter a nossa loja ajuda bastante, porque na época que não tem tanto pedido assim, a gente faz coisas pra loja e acaba vendendo.

E3.42 - tem os seus altos e baixos, depende, aquela coisa do mercado. 
Além da produção de mercadorias, algumas oficinas oferecem também a prestação de serviços como produto do processo de trabalho, como exemplificado a seguir:

E10.4 - A gente participa também de eventos. Como é uma oficina de eventos então a gente faz eventos fora daqui da oficina, então a gente vai até o cliente, então a gente faz almoço, almoço não, a gente faz brunch, café da manha, coffee break, a gente faz festas.

E10.5 (produção) - A gente faz a parte da produção, então a gente faz os alimentos, só que a gente faz: salgadinhos, faz bolo, pães, suco, café, então faz os alimentos pro evento...

E10.6 - a gente serve também, então o pessoal trabalha na produção e trabalha como garçom também quando é solicitado, então eles também são treinados pra trabalhar como garçom.

Sendo assim, podemos concluir que a finalidade do processo de trabalho na oficina refere-se à produção de mercadorias ou prestação de serviços para obtenção de renda. Enquanto instrumento de intervenção do trabalho em saúde do NOT, trata-se de uma estratégia de utilização do trabalho, cuja finalidade última é a inclusão social pelo trabalho (Alcântara, 2007). Contudo, evidenciamos algumas contradições especialmente devido a reprodução das relações sociais de trabalho, que não são meros instrumentos de racionalização do trabalho, mas instrumentos de dominação intelectual dos corpos e mentes dos trabalhadores, efetivados pela alienação no processo de trabalho.

\subsection{Finalidade do Processo de Trabalho em Saúde: Reabilitação Psicossocial pelo trabalho}

A finalidade do processo de trabalho em saúde do NOT, como abordado anteriormente, relaciona-se com a articulação entre dois campos no contexto da saúde mental: assistência e trabalho; conforme afirmação a seguir:

Na construção da assistência de maneira global, o projeto NOT tem papel relevante na busca de respostas para questões relativas ao mundo do trabalho - questões que nos são trazidas cotidianamente pelos usuários. Tem a finalidade de propiciar a integração na comunidade e criar espaços de trabalho que possibilitem ao usuário perceber-se como individuo social, reconstruindo sua identidade e melhorando sua qualidade de vida. As oficinas funcionando em moldes cooperativistas, tornam-se espaços produtores de sociabilidade, resgatando aspectos da vida em sociedade, 
favorecendo a comunicação, a autonomia, o contato com a cultura e a aquisição de novos conhecimentos (Cayres et al., 2001, p. 110-1).

Segundo essa definição, a finalidade do processo de trabalho em saúde refere-se a reabilitação psicossocial pelo trabalho. Como vimos, o modo de produção na oficina é considerado um instrumento primordial para o resgate da capacidade produtiva por meio da aprendizagem de um oficio e da sociabilidade promovida pelas relações interpessoais na produção.

Como abordamos na revisão de literatura, a utilização do trabalho na saúde mental, não é recente e nem sempre foi entendida como uma resposta às necessidades da pessoa com sofrimento mental. Ao contrário, o trabalho nas instituições psiquiátricas tornou-se um dispositivo de tratamento, de punição, de exploração e de normatização na perspectiva do controle e adaptação social dos desviantes para a manutenção da ordem capitalista.

Sendo assim, na perspectiva da atenção psicossocial e da reforma psiquiátrica brasileira, torna-se fundamental romper com o paradigma psiquiátrico que promoveu o isolamento e a exclusão social do louco, onde o papel do trabalho cumpria a função central de controle e adaptação daqueles sujeitos considerados incômodos e improdutivos ao modo de produção capitalista e suas relações, em sua dimensão estrutural.

Cabe ressaltar que na aparência as instituições psiquiátricas não se reconheciam nessa forma excludente e segregadora. Em sua visão, estavam cumprindo uma missão terapêutica, pedagógica e até mesmo inclusiva. Partir dessa aparência, analisando seus elementos constitutivos até chegar a sua essência relacionada ao seu papel na estrutura da sociedade, foi o que possibilitou a crítica da psiquiatria, de seus aparatos e de sua eficácia terapêutica por parte das experiências de psiquiatria reformada mais recentes.

Contudo, nem todas essas experiências de reforma psiquiátrica, radicalizaram (chegaram à raiz) essas criticas para desconstruir a instituição psiquiátrica e seu sistema coercitivo punitivo (Basaglia, 1979). A maioria limitou-se à humanização da assistência e a criação de dispositivos comunitários sem fazer o questionamento fundamental à pseudo 
neutralidade científica da psiquiatria, que legitimou a ideologia dominante na condenação e exclusão dos improdutivos em nome da produtividade capitalista. (Rotelli, 1989).

Como resultado, aparentemente indesejado, assistiu-se ao crescimento do isolamento, da exclusão, da cronificação, da violência, da exploração e da mercantilização da loucura na sociedade ocidental moderna.

Portanto, na perspectiva da desinstitucionalização como emancipação, a utilização do trabalho nas experiências reabilitadoras pressupõe a critica do adestramento e da adaptabilidade do trabalho para reconduzir o sujeito com sofrimento mental à sua condição de ser social capaz de produzir os meios necessários à produção e reprodução da vida, promovendo assim sua autonomia, seu protagonismo e sua emancipação.

Para compreender a utilização do trabalho na reabilitação psicossocial pretendida pela instituição NOT, passamos à analise da finalidade do processo de trabalho em saúde, partindo da sua aparência (proposta da oficina de trabalho), buscando a essência dessa utilização do trabalho, o que também nos servirá para refletir mais adiante sobre as concepções de reabilitação psicossocial, trabalho e cooperativismo, na ótica dos sujeitos da pesquisa.

$\mathrm{Na}$ análise temática dos discursos, identificamos algumas finalidades das oficinas de trabalho com relação ao trabalho em saúde, que buscamos agrupar segundo suas semelhanças e aproximações.

Uma primeira concepção encontrada, portanto, refere-se à oficina de trabalho como um instrumento do processo de trabalho em saúde cuja finalidade vincula-se à intervenção terapêutica. A proposta da oficina neste caso está relacionada à manutenção e à complementação da eficácia terapêutica do tratamento psiquiátrico resultante do acompanhamento e monitoramento da condição psíquica, conforme as frases abaixo:

E7.26 - Então daqui a pouco assim tem hora que a oficina está produzindo, é assim mesmo, mas quem são essas pessoas, porque que ela está assim, porque que ela está do outro, isso é um sinal, isso é um sintoma, isso é melhora, isso não é. 
E2.32 - Então eles têm um acesso ao cuidado e a gente tem contato com a rede, também sempre entrando em contato pra poder auxiliar na oficina.

E10.43 (possibilidades) - acho que tudo isso é uma maneira de ajudar eles a crescerem como pessoas e não desenvolverem a doença, mas conseguir uma melhora.

E10.58 (transformação na vida) - na parte da saúde mental, eu acho que tem mais melhora, muita melhora, ganho sempre.

Os discursos também identificam a estabilização do quadro psiquiátrico e a redução dos sintomas como efeitos terapêuticos da proposta das oficinas:

E11.68 - Então as oficinas de trabalho, tem realmente ajudado muito, nessa transformação, não controle, mas, a manter o quadro psíquico dessas pessoas estável.

E6.5 - Acho que eu vou contar o caso de um oficineiro. Ele entrou na oficina estava com depressão, muito mal, até tinha muita dificuldade com o trabalho e com o tempo, com outros tratamentos também, com psicólogo, psiquiatra, mais as atividades na oficina, ele foi melhorando, a relação com o grupo, a própria atividade em si.

E11.12 - eu acho que esse é um dos objetivos legais que é realmente promover essa melhora do quadro deles.

A redução na intensidade do acompanhamento psiquiátrico e medicamentoso nos serviços assim como a redução das internações são propostas da oficina, apontadas pelos entrevistados, que se alinham nessa concepção da finalidade terapêutica do processo de trabalho, como abaixo:

E11.13 - Tem muitos oficineiros que hoje vão uma vez por mês só pra pegar medicação, não fazem mais um acompanhamento semanal, o próprio CAPS ou centro de saúde deu alta, então isso é a partir do momento que tiveram contato com o núcleo de oficinas, com o trabalho mesmo das oficinas.

E11.67 (transformação na vida) - Muitos pedem alta do CAPS, que não precisam mais, que estão bem, que uma vez por mês basta, e tem muitos que vão hoje uma vez por mês, que antes era três vezes na semana e hoje estão uma vez por mês, porque ficaram estabilizados, que estão bem.

E3.2 - a considerar que realmente a oficina vem, assim, não só completar, do ponto de vista, da saúde mental, que melhora muito, diminui o número de internações...

E3.37 (transformação na vida) - A diminuição do número de internações...

Corroborando com essa concepção, a oficina é entendida como um espaço de socialização e convivência entre iguais, que repercute na 
expectativa social, dos familiares e dos profissionais, com relação à aceitação e melhora do quadro psiquiátrico, especialmente da interação social, conforme frases abaixo:

E2.57 - Mas a gente tenta colocar muito pra eles enquanto grupo, assim: de poder se locomover, de vir, de ir embora junto, de almoçar junto, de fazer amigos.

E6.56 - E as possibilidades, eu acho que é um espaço muito interessante nas oficinas, isso das trocas entre eles, se vê que eles conversam de tudo na oficina, às vezes o que aconteceu na novela, desde questões familiares, então é um ambiente gostoso que eles estão trabalhando, estão desenvolvendo uma atividade, que está ali por trás...

E6.65 - Então eu acho que é uma oficina que propicia bastante as trocas entre eles.

E2.58 - Às vezes eles mesmos têm uma turma que eles se identificam mais.

E7.59 - ...mas tem pessoas que vem aqui que convivem, que senta, que conversa, que é melhor estar aqui do que estar em casa...

Os cuidados com a higiene pessoal, relacionados à melhora da autoestima são apontados como um resultado da participação na oficina, evidenciando novamente uma expectativa social e uma finalidade terapêutica:

E3.18 - Melhorando no sentido geral, ou seja, para a família que dá um retorno, um feedback, os profissionais que, ele continua sendo trabalhado nos CAPSs, os profissionais dos CAPSs percebem a mudança dele, principalmente o cuidado pessoal.

E9.59 - Quando chega um grupo pra você, uma pessoa, você percebe a primeira mudança que é em relação aos cuidados pessoais, normalmente as pessoas chegam descuidadas, meio detonadas mesmo...

E3.19 - O cuidado pessoal já vai mostrando a estima mais cuidada, mais melhorada.

Outra finalidade apontada por alguns entrevistados como proposta das oficinas de trabalho refere-se à desospitalização, conforme abaixo:

E9.12 - Então em termos de hospitalização, pra mim é o maior resultado que se pode ter, em termos de oficina de trabalho, pelo que ela representa pra pessoa, pelo aspecto que ela tem na vida da pessoa, ela consegue mostrar isso com bastante clareza, em termos de desospitalização, que pra mim é o principal, o principal resultado que a gente tem.

O entretenimento e ocupação por meio da aprendizagem ou da realização de alguma atividade ocupacional, durante o processo de 
tratamento, foi apontado como uma das finalidades da proposta de oficinas de trabalho, segundo frases abaixo:

E2.61 - a gente sempre coloca, e eu sempre converso com eles neste sentido de dar valor pra oficina enquanto espaço que eles têm pra vir e se distrair, ter o horário deles...

E10.42 - Então acho que pra eles tarem aprendendo um novo trabalho, e também estarem cuidando da saúde, ou de uma dependência química ou de uma doença, de um problema de saúde mental...

E8.23 - Tem muitos outros casos de pacientes que chega mais depressivo, angustiado, com dificuldade de relações com a família, e aí chega aqui, a gente faz o primeiro acolhimento, uma escuta, se for o caso de uma orientação e passa a tarefa: vamos trabalhar, vamos canalizar a nossa atenção, vamos focar, e chega no fim do dia ele está ótimo, passou, às vezes uma simples orientação. $E$ a própria atividade organiza o individuo.

Essas duas características (entretenimento e ocupação) entretanto configuraram a utilização do trabalho pela psiquiatria desde seu início, que buscando responder às necessidades de manutenção da instituição pela exploração do trabalho não-remunerado, às necessidades da ordem social pelo controle e isolamento dos desviantes e às necessidades de controle e disciplina das paixões e idéias delirantes pela obrigatoriedade do trabalho, traduziu-se numa combinação moralizante e pedagógica entre tratamento e punição, entre submissão ao poder institucional e recompensas medíocres, que tinham muito mais uma intenção ideológica do que terapêutica, marcando profundamente a relação trabalho/psiquiatria.

Mesmo com roupagens mais contemporâneas e humanizadas os herdeiros do tratamento moral reproduzem essa essência da utilização do trabalho na saúde mental, quando afirmam a intenção terapêutica que não corresponde às necessidades reais dos usuários, como veremos mais adiante. Essa lógica deriva em grande parte da ideologia dos trabalhadores em saúde mental, que desqualificam a capacidade produtiva dos usuários, infantilizando-os e submetendo-os as regras disciplinares, exercendo uma função ideológica de adaptação e controle social, que não pode ser confundida com as necessidades terapêuticas das pessoas com sofrimento mental, este último resultante e agravado sobretudo pelo isolamento e desvalorização social. 
Logo, é imperativo que os trabalhadores rompam com essa pseudo neutralidade da psiquiatria e optem pelos interesses dos usuários, com destaque à autonomia e ao protagonismo, conscientizando-se que não podem servir de instrumentos de dominação, transformando-se, ao contrário, em instrumentos de emancipação pela práxis coletiva. Enfatizamos que não se pode mais esconder a ideologia nem o conflito de interesses, pois essa omissão foi responsável pelos mais variados tipos de violências, das mais evidentes às mais sutis, e formas de controle, das mais centralizadas às mais dispersas.

A orientação para o funcionamento social no cotidiano, entendida como adequação dos comportamentos nas interações sociais diárias, nos espaços do trabalho, de recreação e familiares, é percebida como proposta das oficinas de trabalho, na visão de um dos entrevistados:

E4.5 (proposta da oficina) - ...ela tem um propósito de estar trabalhando mesmo o cotidiano deles...

E4.6 (cotidiano) - que é a questão do trabalho, a questão da família, a questão do lazer.

E4.10 (proposta da oficina) - Eu acho que diariamente, no cotidiano deles aqui na oficina.

E4.9 - de repente que um usuário, que um dos oficineiros, usuários, ele está com alguma dificuldade dentro do cotidiano dele, ele traz pra gente, a gente consegue trabalhar, e no decorrer do dia ele já vai sentindo melhor, se sentindo mais aceito...

A melhoria da qualidade de vida é apontada como proposta das oficinas, entretanto percebe-se uma conceituação vaga e imprecisa sobre seus elementos constitutivos, associados tanto a fatores emocionais como auto-estima e auto-confiança quanto a fatores econômicos, como abaixo:

E4.52 - Então eu acho que a oficina, ela tem as possibilidades de melhora de qualidade de vida mesmo pro indivíduo.

E4.56 (transformação na vida)- como a gente já disse, é a qualidade de vida, eu vejo, assim, eu entendo a oficina não só como uma forma de geração de renda, eu entendo a oficina como melhoria mesmo da qualidade de vida total deles, porque eles se sentem melhor e automaticamente mais úteis, mais dispostos, e isso melhora a saúde, melhora a doença em si.

E7.81 - ...eu acho que essas possibilidades assim, muito rica, da melhora da qualidade de vida do sujeito.

E10.54 - (transformação na vida) Eu acho que pra maioria deles a oficina é importante, tem alguns que dão muito valor pra oficina, vem 
com prazer mesmo, achando que vai ser uma proposta que vai ajudar a melhorar a qualidade de vida deles, ajudar na parte financeira...

Muitos entrevistados se referem à oficina de trabalho como uma proposta de reinserção social do usuário da saúde mental, como abaixo:

E4.4 - É porque assim a oficina, eu acho que ela tem um propósito além da reinserção social deles...

E4.50 (possibilidades) - eu acho que as possibilidades da oficina, é como a gente já vem dizendo assim, é proporcionar mesmo ao indivíduo uma reinserção dele na sociedade, não obrigatoriamente no mercado de trabalho.

Em outros fragmentos, a noção de reinserção social foi vinculada à inserção no mercado de trabalho formal por meio da aquisição e/ou treinamento de habilidades ocupacionais e às atitudes exigidas pelas relações de trabalho:

E4.27 - existem casos que a gente que tem, que eles são contratados, que eles são reinseridos na sociedade e existem outros casos que eles estão aptos completamente para o trabalho, mas não conseguem uma vaga.

E5.22 - Eu acho que as possibilidades, nas oficinas de trabalho os oficineiros têm a possibilidade de serem inseridos novamente no mercado de trabalho, além de aprender uma nova profissão.

E10.41 (possibilidades) - Acho que pra eles o que a oficina pode oferecer é estar ensinando mesmo um novo trabalho, tem alguns oficineiros que saíram daqui e conseguiram um emprego fora...

Nos casos de ingresso ao mercado de trabalho formal, os oficineiros são desligados das oficinas, podendo manter contato com o serviço, se desejarem, mas esse acompanhamento não configura uma intervenção do serviço:

E11.74 - Porque ele constituiu uma família, então exigência dele ganhar mais, de ser registrado e tudo mais. Então ele foi e já tem um tempinho, só que sempre existe uma ligação dele: ah posso voltar?

E5.5 - porque depois não tenho pernas pra ir seguindo o sujeito. $O$ último, ele conseguiu um emprego numa padaria, que ele ia começar como ajudante de limpeza e depois ele iria passar pra aprender o ofício de confeiteiro, mas aí você segue durante alguns meses, depois você não consegue, dar seguimento e ver como que ele está. Eu sei que ele está bem, mas também já me desvinculei dele.

As temáticas sobre o cotidiano, a qualidade de vida, a capacitação profissional e a reinserção social, referidas pelos entrevistados, carecem de 
aprofundamento e problematização para não incorrer no equívoco de utilizar conceitos aparentemente coerentes, entretanto vazios ou confusos e portanto, mantenedores da qualidade anterior. É fundamental qualificar os conceitos, desconstruí-los, reinventá-los e averiguar sempre à que ou quem servem na essência, lembrando que muitos discursos aparentemente inovadores, não promoveram uma ruptura radical: permitiram alguns ganhos aos usuários, mas mantiveram o controle nas mãos dos detentores do saber-poder.

O processo de produção de mercadorias e de geração de renda são referidos como propostas das oficinas, especialmente na percepção dos entrevistados acerca do interesse e valorização dos usuários quanto à obtenção de recursos financeiros voltados à satisfação de suas necessidades. Logo, para os usuários o valor do trabalho está relacionado à geração de renda:

E2.34 - e a geração de renda, porque eles sempre têm uma bolsa oficina no mês, dependendo do que a gente vende, do lucro que a oficina tem, pra gente poder repartir com eles.

E2.63 - Mas a gente nota que tem hora, pra eles assim o importante é mais o dinheiro, porque muitos perderam o emprego, alguns nunca trabalharam então eles dão valor mesmo.

E6.60 - Então a gente vê que isso é uma grande possibilidade que a oficina oferece: a questão da geração de renda.

E10.11 - se eu for ver uma situação que expresse a proposta da oficina, acho que a situação seria a produção de salgados, seria 0 trabalho deles em eventos, que, gera uma bolsa pra eles..

E10.55 - ...é uma oficina que paga uma bolsa boa, a gente tem uma renda, um caixa bom, uma renda boa por mês, então a gente tem condições de pagar uma bolsa boa...

A reabilitação psicossocial associada à geração de renda, foi identificada como uma proposta da oficina de trabalho por apenas um entrevistado:

E10.10 - a proposta da oficina que eu vejo é a reabilitação, e também o trabalho de geração de renda.

$\mathrm{Na}$ visão de alguns entrevistados, a oficina de trabalho possibilita a oferta de trabalho real para usuário, podendo estabelecer um vínculo mais formal com a instituição através da contratação como monitores ou como 
funcionários do hospital (Projeto Parceria), de acordo com os fragmentos abaixo:

E6.18 - E tem outras pessoas que estão na parceria, que é um projeto também de oficinas do NOT, mas que tem essa parceria com o Cândido, com o serviço de saúde. Então eles passam a trabalhar em setores do hospital mesmo, na cozinha, na parte de higiene, e aí tem uma bolsa fixa.

E5.2 - A situação que mais ilustra a proposta da oficina é a do monitor que foi contratado e antes era usuário da mesma.

Entretanto, para a maioria, esse mercado de trabalho oferecido pelas oficinas não consiste no estabelecimento de um vínculo empregatício nem numa relação cooperada como a figura do sócio nas cooperativas. Trata-se de uma relação assistencial, que ainda assim, não prejudica o valor do trabalho pelos oficineiros, como se vê nas frases abaixo:

E2.20 - e tem gente que tem perfil pra ser NOT a vida inteira, então acabam ficando na oficina.

E8.31 (limites/dificuldades) - Eu acho que o que sempre gera uma discussão, uma ansiedade, uma angústia, é a questão das vendas, porque as oficinas hoje é um mercado de trabalho, é um mercado de trabalho pros oficineiros.

E8.37 (transformação na vida) - a oficina de trabalho é o mercado de trabalho porque a gente aprimorou, aperfeiçoou, a gente está ampliando...

E11.70 - E é por isso que acho que não tem mais um rodízio, como era o objetivo inicial, de ficarem aqui, de serem preparados pra um trabalho lá fora, porque gostam e querem ficar. E não querem sair de jeito nenhum.

Embora mantenham essa intenção terapêutica, os entrevistados apontam para a necessidade de mudanças. Na visão de alguns, o processo de trabalho do NOT deve conciliar a intervenção terapêutica com a geração de renda por meio da produção na oficina de trabalho, como vemos abaixo:

E7.80 - Você vai da assistência à produção.

E5.1 - Então as propostas das oficinas de trabalho além de terapêutico é a inserção dos usuários no mercado de trabalho através da geração de renda.

E7.53 - ... a gente fala que é NOT um e NOT dois, que tem pacientes que tem uma demanda, claro todo mundo quer ter uma renda, mas eles têm uma necessidade de convivência.

E8.22 (proposta da oficina) - É isso, é no dia a dia estar manejando, você estar fazendo uma escuta, fazendo um acolhimento da crise, ao mesmo tempo conciliar com a produção, que pressiona. 
E11.61 - Existe a coisa do espaço, das relações sociais, também, mas você receber aquilo, pra eles é assim uma transformação muito grande.

Avaliamos que essa contradição presente na visão dos entrevistados fundamenta-se no receio de perder sua identidade de trabalhadores da assistência, associada primordialmente à realização de intervenções diagnósticas e terapêuticas do modelo clínico.

E7.21 - ...no começo foi assim, difícil pra equipe, porque quando foi surgindo esse mercado que a gente foi entrando em contato com a idéia da imensidão nos assustou um pouco, porque assim parecia que a gente ia sair da assistência e virar uma empresa, então assustou.

Entretanto, não se trata de abandonar a assistência e os cuidados com os usuários, mas de subverter o poder psiquiátrico nas relações assistenciais que reproduzem a ideologia dominante e o papel do trabalho alienado em garantir a dominação de uma classe sobre a outra. Trata-se sobretudo de responsabilizar-se, segundo a concepção italiana, pela transformação concreta da vida material e subjetiva, o que envolve uma articulação complexa entre saberes e práticas, que objetivem a desinstitucionalização como emancipação.

Essas contradições são evidenciadas também pelas dificuldades identificadas pelos entrevistados na execução e no produto final de seu trabalho, que serão tratadas a seguir.

\subsection{Dificuldades e Possibilidades: contradições a serem superadas}

Conciliar as intervenções terapêuticas do trabalho em saúde com a finalidade do processo de produção nas oficinas - produção de mercadorias para comercialização e prestação de serviços - é uma dificuldade referida pelos entrevistados, que resultam em intervenções contraditórias e em problemáticas pautadas nas reuniões e supervisões da equipe técnica:

E6.55 - A gente tem conseguido fazer isso em todas as oficinas, assim, mas é um nó também.

E6.52 - E isso também da gente ter muitas pessoas com muita dificuldade dentro da oficina, é uma questão que a gente tem discutido em equipe...

E11.46 - Ocorre que a gente tem discutido a respeito disso na equipe sobre as pessoas que tem mais dificuldade, menos 
dificuldades, como que a gente pode rearranjar isso de uma melhor maneira possível sem excluir, sem excluir ninguém.

E8.20 (proposta da oficina) - é um caso particularmente assim difícil, porque, em supervisão eu fui orientada a ter um distanciamento pra preservar um pouco a relação, porque é uma transferência muito grande comigo, mas ao mesmo tempo eu preciso estar orientando ela com relação à atividade, ao mesmo tempo eu tenho que uma proximidade com ela.

Uma dificuldade relacionada ao perfil dos oficineiros refere-se ao seu comprometimento físico e psíquico, que se traduz em falta de habilidade e baixa produtividade dessa população com sofrimento mental, e em alguns casos, em nenhuma produtividade, como depreendido nas frases abaixo:

E4.54 - E as dificuldades limites, eu acho que cabe de cada um mesmo, o limite de cada um, e as dificuldade pra estar executando as tarefas, porque têm alguns que tem restrições físicas, e aí vem essa dificuldade mesmo, deles com a tarefa em si.

E5.25 - E as dificuldades, eu coloco como dificuldades internas ou de capacidade física, muitas vezes os oficineiros não conseguem, devido ao limite físico ou psíquico de participar das atividades das oficinas, devido ao comprometimento decorrente da doença. Eu acho que isso é o que dificulta realmente.

E10.39 - às vezes até o próprio tratamento, dependendo da doença a pessoa tem mais dificuldade, mais limitações...

E7.57 - ... tem gente que não consegue fazer isso. Então o paciente vai fazer, tira o grampo, corta o papel, não saí, não saí, fica numa ansiedade, muita informação.

E6.53 - Essas pessoas que tem mais dificuldade, como que a gente vai inseri-las nas oficinas, que daí elas acabam não conseguindo pegar a atividade em si.

E7.54 - A maneira como eles se comportam, se apresentam é da convivência, eles não conseguem produzir. Eles não conseguem entrar na linha da produção, entendeu? Às vezes por falta de habilidade.

Essas limitações decorrentes do transtorno mental com relação à capacidade produtiva resultam por vezes numa ambivalência entre assistência e produção, por serem dois campos de atuação distintos que não necessariamente conseguem caminhar junto, tornando a atuação dos coordenadores conflitante e por vezes contraditória, conforme as frases abaixo:

E7.38 - Às vezes se adapta bem à convivência do grupo, não se adapta a técnica, e aí assim, como é que você faz?

E7.69 - Das dificuldades, eu tenho visto assim que ultimamente tem vindo casos cada vez mais graves pra gente poder cuidar, e aí, vou 
ser repetitiva porque acho que talvez seja minha preocupação de olhar o sujeito com toda essa complexidade, você tem que olhar mas trabalhar vendo o sujeito...

E2.23 - como fazer para atender estes usuários que não necessariamente vem com alguma especialidade ou sabe fazer alguma coisa?

E9.35 - você não acha uma mão de obra formada dentre o pessoal dos doentes mentais em geral, não é uma facilidade.

E10.35 - Tem a dificuldade também da não qualificação dos próprios oficineiros...

E11.49 - É uma coisa que você tem que estar trabalhando com isso diariamente, até com eles sobre as responsabilidades que eles têm, perante a oficina, mas não é tão simples assim.

E2.22 (limite/dificuldade) - Com o aumento da produtividade e procura dos serviços a gente precisa às vezes de mão de obra um pouco mais qualificada.

O atendimento às necessidades terapêuticas dos oficineiros, finalidade do processo de trabalho em saúde, muitas vezes dificulta 0 controle da produção, resultando muitas vezes num conflito para o coordenador que fica dividido em responder a essas duas demandas, segundo as frases abaixo:

E6.54 - Aí a gente adapta à atividade, mas se tiver muitas pessoas assim na oficina a gente não consegue também ter produção.

E11.47 - Então existem momentos que a gente recebe um, faz uma feira, daí vem aquele monte de pedidos, e de repente aquela semana falta cinco do grupo, e isso aconteceu na outra feira, teve muitas pessoas que faltaram, e mais dificuldade de realizar, algumas tem dificuldade de realizar atividade que estavam fazendo, que não estavam muito legal e tudo mais.

E11.48 - Então atrasa, atrasa aquele pedido, e o cliente não quer saber se a pessoa está em crise, se não está bem, se está em crise, se está depressiva, se não está legal, então não é tão simples assim.

E11.30 - eu tenho um caso, essa pessoa está em crise faz trinta dias já, está deixando todo mundo doido, mas é possível, porque ela não quer internação, não quer leito-noite, tem assim um horror à internação, então a gente está tentando lidar com, junto com o centro de saúde, referência dessa pessoa...

$\mathrm{Na}$ avaliação dos entrevistados, embora considerada uma articulação complexa, a conciliação entre assistência e produção não é impossível, exigindo a capacidade de inventar estratégias constantemente como adaptação da atividade, redução do ritmo de produção, remanejamento de 
funções, aumento do número de oficineiros, reuniões diárias com o grupo de trabalho, ou admitir a presença desse oficineiro na oficina, como apontado nas frases:

E8.21 (proposta da oficina) - Mas a gente acaba conseguindo com que ela fique um pouco melhor, tenha os sintomas amenizados, a partir da interferência do grupo, da atividade do monitor que vai entrando e apontando que tem uma tarefa, que tem uma produção, que tem que dar conta, que a gente pode cuidar disso num outro momento e que ela vai ficar bem com relação a esses sintomas, a esses sentimentos, como das outras vezes, ela ficou bem também, vai passar.

E10.40 - o oficineiro já está inserido na oficina, então a gente tem que acabar lidando com isso, não pode simplesmente desligar, tem que acolher, e colocar aí numa função mais simples, de lavagem, limpeza, então às vezes dá uma remanejada no pessoal, mas é uma dificuldade também.

E11.32 - então a gente tem que ter uma tolerância maior, tem que saber que tipo de peças você vai dar. Não dá pra você poder contar muito com, tipo assim: olha isso aqui tem um prazo eu quero que você faça em dois dias, não posso. Então vou ter que deixar no ritmo dela.

E11.33 - Então eu dou uma avaliada, se eu não posso dar essa peça, porque isso aqui é um pedido, então eu vou dando aquilo que ela consegue realizar nesse momento.

E11.34 - E conversas constante com o grupo, isso é diário, porque, por incrível que pareça a tolerância deles é pequena, quando alguém da oficina está em crise...

E11.35 - porque eles ficam extremamente exigentes com as atividades, com prazos de entrega, então a tolerância deles é pouca em muitos momentos. Então a gente tem que ter uma conversa constante, pra eles terem paciência, entender a crise, o que é mais difícil pra eles.

Nesse sentido, os coordenadores demonstram a possibilidade de reflexão e elaboração coletiva, quando podem experimentar a autonomia, a criatividade e a cooperação entre seus pares, que deveria estender-se ao processo de trabalho nas oficinas.

Embora não apontada pelos entrevistados, encontramos na literatura, a dificuldade relacionada à baixa escolaridade e conseqüente dificuldade de comunicação dos oficineiros, prejudicando o desempenho necessário à realização de algumas atividades e obstaculizando a autonomia e o protagonismo necessários à participação no controle do processo de trabalho: 
A baixa ou nenhuma escolaridade da maioria dessa população acaba por impor obstáculos e até mesmo limites no desempenho de algumas atividades. $\mathrm{O}$ analfabetismo e a incapacidade de utilizar raciocínios matemáticos chegam a impedir o crescimento dos oficineiros quando certas atividades exigem esses conhecimentos. A dificuldade em expressar-se oralmente faz com que muitos oficineiros optem por silenciarem e deixam, muitas vezes, até de contribuir com o grupo com suas idéias, críticas e sugestões (Alcântara, 2007, p.169).

Com relação à produção, os discursos identificaram dificuldades relativas à flutuação do mercado de consumo e diversificação dos produtos, traduzindo-se na necessidade de pesquisa de mercado, outra tarefa do coordenador, que na visão de alguns entrevistados, demanda uma pessoa mais qualificada:

E7.76 - Porque você já está dentro da assistência, da produção da coisa, já é muito trabalho, entendeu? E aí a gente tem que tomar cuidado como coordenador: eu não pesquisei o mercado, nossa. É porque é muito amplo isso, entendeu?

E7.77 - Então às vezes assim, pra crescer, as dificuldades, acho que são essas, talvez se a gente tivesse, assim, uma pessoa que faça essas pesquisas, uma pessoa que te traga respostas, aí você fica com o planejamento assim...

E7.74 - Então é um mercado que, eu acho isso uma grande dificuldade de conhecer, você tem que pesquisar, você tem que lançar produtos novos, eu acho que isso é um desafio muito grande pra gente que é da área da saúde.

A comercialização da produção, as exigências de pontualidade, a falta de recursos financeiros, são dificuldades apontadas pelos entrevistados, especialmente à geração de renda, conforme frases abaixo:

E6.50 - Então por enquanto assim, a gente não ficou sem trabalho, mas às vezes o caixa fica negativo, porque gasta com material, pra ir pra uma feira, por exemplo, pra GIFTI, a gente tem que comprar o material antes, pra poder confeccionar os produtos e mandar pra feira.

E7.73 - Das dificuldades, enquanto geração de renda, eu acho que esse trem desse mercado. Porque você nunca sabe como ele vai funcionar.

E11.41 - ...a gente botou os nossos produtos no mercado lá fora, então a gente apresentou em feiras, internet, tem essa loja, e as pessoas, querem qualidade, pontualidade, tudo que um cliente tem direito de querer, por estar pagando por um produto.

E6.43 - a gente depende muito das vendas pra garantir uma bolsa legal pra eles. E não é sempre que a gente vende bem, então isso é uma coisa que é uma dificuldade na oficina, para o mercado assim... 
E8.34 - Então é a questão da venda, a gente tem que vender o produto, tem que estar sempre aprimorando, inovando, buscando novidades pra vender, buscando clientes que é mais difícil ainda, pra entrar dinheiro e fazer o pagamento, essa é uma tarefa muito difícil.

Alguns entrevistados também apontaram como dificuldade em relação à continuidade do tratamento, o fato do oficineiro não desejar locomover-se até o local de tratamento e perder essas horas de trabalho, que poderiam ser contabilizadas para o cálculo da bolsa:

E8.28 - aí ele vem pra oficina de manhã, à tarde ele tem que ir pra um CAPS, um CAPS álcool e drogas, só que daí ele já esgotou a passagem dele...

E8.29 - ...às vezes ele, ele também, o oficineiro ele já não quer ir, tem uma resistência a ir ao tratamento, porque ele não vai receber essas horas que ele esta lá.

E8.30 - E aí ele também não faz reserva do passe, porque ele tem um limite de quatro passagens diárias, e aí não dá pra ele ir ao tratamento, ou ele não pode vir na oficina o dia todo, porque o tratamento é muito longe da casa e tem que pegar uns quatro ônibus, então isso é uma dificuldade.

A constatação dessas dificuldades ao longo da experiência das oficinas é representada pela diferenciação entre dois grupos que apresentam necessidades distintas, definindo por sua vez finalidades diferentes ao processo de trabalho nas oficinas e ao processo de trabalho em saúde:

O primeiro inclui usuários mais dependentes que apesar de necessitarem de orientações constantes possuem capacidades para escolher uma atividade profissional e conseguem organizar as tarefas, tornando-se a oficina instrumento facilitador da retomada ao trabalho ainda que em ambiente protegido. O segundo grupo é caracterizado por usuários mais independentes que realizam as atividades com autonomia e que encontram dificuldades relacionadas ao retorno à profissão anteriormente desempenhada, sendo a oficina um meio favorável à sua reorganização e consequentemente à reinserção no mercado de trabalho (Cayres, et. al., 2001, p. 111-2).

A concepção de trabalho assalariado, que predomina o entendimento da sociedade, e dos coordenadores, monitores e oficineiros, é identificada por um dos entrevistados como uma das dificuldades da organização das oficinas de trabalho segundo a proposta do cooperativismo, no que se refere à auto-gestão, obstaculizada também pela cultura assistencial:

E1.181 - E também a questão de gestão do próprio negócio, que falta às vezes capacitação pro coordenador, e falta também muitas 
vezes pro oficineiro. Pro oficineiro também é a questão do entendimento dessa nova proposta da Economia Solidária, de um trabalho cooperado. Eu percebo que todos vêm muito com a lógica do mercado.

Com relação à estrutura do serviço NOT, os entrevistados referiram algumas limitações, dentre elas, o aumento da capacidade de atendimento, entendido como uma necessidade que, no entanto, depende do convênio firmado entre o SSCF e a SMS, conforme frases abaixo:

E3.20 - Quanto aos limites que eu digo é quanto ao número...

E2.21 - Limite/dificuldade eu acho assim: recurso financeiro, porque a gente depende de um convênio com a prefeitura, tem uma concessão com a prefeitura, então é verba da prefeitura, assinatura de convênio, número de pacientes que a gente pode, os usuários que a gente pode atender.

E7.66 - Nesse momento eu acho que os limites é assim, essa coisa da possibilidade de você crescer com essa população você fica ainda amarrada à questão da, junto à Secretaria Municipal da Saúde.

E9.42 - Eu diria assim, que os limites são impostos pela própria burocracia e pela parte financeira do projeto, porque nós temos uma quantidade de pessoas, que a gente pode ter e que é viável pra gente trabalhar com elas, visto que já existe um acordo feito com, então a gente não tem tanta facilidade de abrir vagas, por conta da própria saúde.

E9.49 - Então pra mim a maior dificuldade seria isso, a gente conseguir fazer tanto em tão pouco tempo e com tão pouco dinheiro. E ainda a gente achar que ainda é pouco, porque tem tanta gente esperando pra entrar no mesmo esquema.

Portanto, a falta de investimentos na infra-estrutura, nos recursos materiais e humanos é considerada como um limite à possibilidade de crescimento do serviço e de produção na oficina, conforme frases a seguir:

E10.32 - Umas das dificuldades que a gente tem é em relação ao espaço físico, é uma dificuldade que a gente tem lá na oficina. Tem dia que a gente tem muita encomenda e a gente não consegue pegar tudo por falta de espaço mesmo pra estar produzindo.

E9.57 - Mas, vai do acordo que se faz com secretarias, pra ter mão de obra pra fazer isso, com a equipe que está é difícil, porque está todo mundo sobrecarregado, e mais ou menos fazendo já tudo que pode, mas se houver essa possibilidade acho que seria muito bom.

E10.38 - Então a dificuldade também da questão de monitores, de auxílio para estar ajudando na produção.

E7.68 - Então eu acho que esse é um limite que todo crescimento, toda vez que você vai pensar em crescer, esbarra nisso, porque assim pra você aumentar uma oficina pra, depende de recursos humanos, depende de aumentar a alimentação. 
Essa dependência do Estado, contraditoriamente, é vista pelos entrevistados como limitação à sustentabilidade e à auto-gestão das oficinas:

E9.43 - As oficinas se elas conseguirem se sustentar, a gente teria mais facilidade de abrir outras vagas, porque pela rede não é uma coisa assim tão simples, teria que haver outras conversas.

E11.78 - A gente tem objetivo também de pagar uma bolsa melhor, de ser uma oficina auto suficiente, que consiga bancar todas as coisas da oficina sozinha tipo funcionário, a gente gostaria, mas não é possível, quer dizer, talvez seja possível, nesse momento não é possível.

Sobre as possibilidades das oficinas de trabalho do NOT, os entrevistados apontaram primordialmente o crescimento do serviço por meio da ampliação da capacidade de atendimento e da capacidade de produção:

E9.52 - Eu acho que tem todas as possibilidades de entrar em qualquer mercado e de atender muitas demandas, a gente não tem pernas nem estrutura no momento pra tanta coisa que pode vir.

E11.50 (possibilidades) - a gente tem tentado assim, atingir um mercado maior, que são arquitetos, então ela, existe uma possibilidade muito grande, de ter uma oficina maior, de atender, atender mais pessoas, de crescer, de crescer assim realmente.

E11.53 - Então acho que uma das maiores possibilidades da oficina é aumentar esse número de vagas, mas pra aumentar esse número vagas, a gente precisa vender o nosso produto, porque senão não adianta a gente ter um monte de pessoas dentro da oficina e não conseguir pagar uma bolsa razoável. Existe uma frustração muito grande entre os oficineiros quando isso não acontece.

Com base na análise do processo de trabalho em saúde e do processo de produção nas oficinas, onde pudemos identificar os elementos gerais que constituem o modo de estruturação do serviço NOT, na visão dos coordenadores, bem como as contradições encontradas, dispomos de melhores condições para passar à análise de algumas concepções que fundamentam esses processos de trabalho para garantir os produtos finais, em outras palavras, para atingir os resultados previstos pelo serviço. Nesse sentido, consideramos importante analisar as concepções sobre reabilitação psicossocial, trabalho e cooperativismo que norteiam o projeto e as práticas do serviço NOT, segundo os coordenadores das oficinas de trabalho. 


\section{CONCEPÇÃO DE REABILITAÇÃO PSICOSSOCIAL, TRABALHO E COOPERATIVISMO SOCIAL}

\subsection{REABILITAÇÃO PSICOSSOCIAL}

De acordo com a revisão de literatura, a necessidade de reabilitação no campo da saúde surgiu no contexto do pós-guerra como necessidade de reprodução da força de trabalho, consumida tanto pelo aumento da produtividade quanto pelas duas grandes guerras, de onde retornaram os indivíduos que tinham necessidade de serem reinseridos no mundo do trabalho.

No campo específico da saúde mental, o termo reabilitação foi empregado nos principais processos de reforma psiquiátrica deflagrados nos EUA e na Europa. A desospitalização promovida por esses processos resultou na necessidade de reabilitação da população de usuários que estavam distribuídos pelos grandes hospitais psiquiátricos e que apresentavam uma complexidade de demandas relativas à sua reinserção social.

A concepção de reabilitação implementada no contexto do processo de desinstitucionalização da Psiquiatria Democrática Italiana foi profundamente crítica às demais experiências de psiquiatria reformada de tipo comunitário que se caracterizavam essencialmente pela desospitalização como resposta à demanda econômica da época com relação à redução de custos e ao incremento de força de trabalho determinadas, portanto, pelas idéias neoliberais que predominavam a ordem capitalista. Tratava-se, sobretudo, da resposta técnica a uma demanda econômica (Basaglia, 1971).

Como vimos, a determinação das necessidades humanas, particularmente referidas à saúde, estão diretamente ligadas às concepções do processo saúde-doença, que, por sua vez, são resultantes do modo de produção e reprodução da vida em cada período histórico.

Partindo dessa premissa teórica do pensamento marxista, utilizaremos como referência de análise, a concepção de reabilitação 
psicossocial apresentada inicialmente pelos reformadores italianos, que foi sendo dialetizada pela experiência brasileira de reforma psiquiátrica. Não se trata de uma concepção fechada e rígida, mas, ao contrário, de uma concepção que está em constante processo de desconstrução/invenção, parafraseando Amarante (1996), e que se fundamenta no campo psicossocial e no horizonte estratégico de ruptura com o paradigma psiquiátrico e de desinstitucionalização como emancipação.

Entretanto, para efeito de análise e contraposição devemos apresentar sinteticamente, sem a pretensão de aprofundamento, alguns modelos de reabilitação psicossocial utilizados no campo da saúde mental que se assemelham às concepções dos sujeitos desta pesquisa.

Cabe ressaltar que tais concepções identificadas nos discursos não aparecem de forma clara e diferenciada, mas ao contrário, mesclam-se e confundem-se em diversas teorias e práticas, corroborando com a análise sobre a produção científica acerca das experiências de reabilitação psicossocial no eixo trabalho (Nascimento, Pinho, Taleikis, 2006).

De acordo com a literatura cientifica que aborda a temática da reabilitação psicossocial na saúde mental ${ }^{28}$, é consenso de que a noção de reabilitação tradicionalmente refere-se à restituição a um estado anterior e/ou restituição à normalidade do convívio social ou de atividades profissionais.Fundamentada nessa noção, a reabilitação foi utilizada por muito tempo como forma de restituição social do indivíduo, especialmente com o propósito de seu retorno ao mundo do trabalho. No caso da saúde mental, o trabalho foi utilizado como um recurso tanto de diagnóstico, terapêutico e como elemento indicador de cura. $\mathrm{Na}$ psiquiatria, essa concepção resultou na proposta de ressocialização e reintegração social do louco, principalmente pela utilização do trabalho como um instrumento normatizador, disciplinador e controlador. Neste caso, a concepção de saúde-doença é definida como quebra das regras de sociabilidade, sendo a cura voltada à readaptação social, não apenas pela abolição das condutas

${ }^{28}$ A esse respeito ver, Amin e Silva Filho (2000), Saraceno (2001), Pitta (2001), Benetton (2001) e Basaglia (1971). 
inaceitáveis, mas pela produção de novas características corporais, sentimentais e morais (Costa, 1989 apud Barros, 2001). O critério adaptação - desadaptação define-se como meio de avaliação do comportamento normal e patológico, na qual o corpo sadio ou doente é apenas um instrumento para o trabalho, devendo ser disciplinado e reabilitado. Tais concepções alinham-se, portanto, ao pensamento positivista predominante na área da saúde (Barros, 2001).

Sendo assim, reabilitar, de acordo com essa lógica, significa recuperar a habilidade dos sujeitos acometidos por alguma doença ou distúrbio, que produziu uma limitação ou perda (desabilitação), gerando, por conseguinte, uma deficiência (desvantagem). Essa deficiência é uma condição que se refere à organização social e não ao sujeito e sua desabilitação (Saraceno, 2001).

Em sua obra, Saraceno (2001) apresenta quatro modelos conceituais e operativos importantes da chamada reabilitação psiquiátrica, com os quais confronta-se na elaboração de uma nova proposta de reabilitação psicossocial, que no entanto, não foi definida pelo autor como uma teoria, mas como questionamentos e diretrizes fundamentais à reformulação dessa estratégia, em consonância com os princípios éticos que orientam a proposta da desinstitucionalização como emancipação.

Nesse sentido, vamos apresentar os elementos simples constitutivos de alguns modelos que servirão de referência para análise das concepções de reabilitação psicossocial presentes nos discursos dos entrevistados, que não são identificadas por eles como modelos, mas pelas suas conceituações aproximam-se desses modelos teóricos e práticos, que, por sua vez, agrupamos em dois blocos segundo sua finalidade última: o primeiro apresenta os modelos alinhados ao paradigma psiquiátrico, que denominamos reabilitação psicossocial como adaptação social; e o segundo, relacionado às reformulações profundas desenvolvidas pela desinstitucionalização italiana, que denomina-se reabilitação psicossocial como cidadania. 


\subsubsection{Reabilitação Psicossocial como Adaptação Social}

Um modelo deste bloco que identificamos nas frases temáticas tratase do modelo de treinamento de habilidade social, que se origina na perspectiva behaviorista apresentada principalmente por autores norteamericanos: Liberman, Wallace, Bellack, Antony e Farkas. O modelo conceitual dessa concepção é o bio-psico-social que explica a desabilidade dos distúrbios psíquicos como resultado de quatro elementos fundamentais: a vulnerabilidade, o stress, o "coping" e a competência (Saraceno, 2001).

Em linhas gerais, esse modelo sustenta que a vulnerabilidade individual, de natureza psicobiológica, seria agravada por eventos da vida estressantes e imprevisíveis como a exposição prolongada à tensões nos ambientes familiares, sociais ou de trabalho que sobrecarregariam as habilidades pessoais de enfrentamento dessas situações, revelando-se por conseguinte em sintomas psicóticos. Portanto, a reabilitação promoveria duas estratégias de intervenção: o desenvolvimento de habilidades sociais do paciente e o desenvolvimento dos recursos ambientais.

O conceito preciso de habilidades sociais difere entre os autores desse modelo, mas refere-se basicamente aos comportamentos externos do sujeito, relacionados ao seu funcionamento social, que seriam alvo de diagnóstico e treinamento no interior do setting educativo-terapêutico com o objetivo final de assegurar níveis cada vez mais elevados de adaptação social. Embora considere a importância da participação de familiares e amigos em contextos de vida real e o direito de escolha do cliente, esse modelo simplifica o âmbito social, de trabalho e de aprendizagem, acreditando que essas habilidades sociais treinadas poderão ser transpostas às situações de vida real do paciente (Saraceno, 2001).

E6.7 - eu acho que a oficina, ela, o nosso objetivo é esse, assim, a questão do convívio entre as pessoas, ela melhorar as suas questões de habilidade.

E6.8 - Habilidade em todos os sentidos da vida, assim, desde a atividade em si, ser uma pessoa produtiva, quanto das relações, voltar a se relacionar, a ter amigos, então, eles falam muito que acaba tendo uma família ali dentro da oficina...

Outro modelo alinha-se com os modelos psico-educativos, que não apresentam limites precisos com a abordagem comportamentalista do 
modelo anterior. Os próprios expoentes de ambos os modelos (Liberman, Falloon, Leff, Vaugh) defendem a integração dos princípios do treinamento de habilidades sociais e da psico-educação na perspectiva terapêutica. Ambos têm como referencial o modelo bio-psico-social que localiza a vulnerabilidade no indivíduo e na interação com fatores de stress ambiental, em especial, nas relações familiares (Saraceno, 2001).

Os estudos que estão na base desse modelo tratam das Emoções Expressas (EE), que, em linhas gerais, buscam estabelecer as variáveis relevantes à adaptação social dos psicóticos em processo de desospitalização e também identificam os fatores de recaída. Para essa proposta, as EE estariam relacionadas aos aspectos verbais e não-verbais da comunicação entre pacientes e familiares, fatores considerados de risco para recaídas: comentários críticos, hostilidade, hiperenvolvimento emotivo e empatia (Siciliani, Burti, 1991 apud Saraceno, 2001).

Portanto, a finalidade da intervenção psico-educativa dirige-se a diminuição ou impedimento das recaídas, configurando um objetivo terapêutico e reabilitador. Utilizando intervenções educativas destinadas às famílias, organizadas em níveis de complexidade, que estabelecem regras básicas à comunicação para a convivência, as diferentes estratégias propostas por estes modelos consideram o núcleo familiar um importante recurso reabilitador.

Esses modelos além de ignorar o nível social do funcionamento do indivíduo na prevenção de recaídas, não apresentam o caráter específico da reabilitação, uma vez que estão reduzidos à orientação destinada aos familiares dos pacientes (Saraceno, 2001).

$\mathrm{Na}$ análise dos discursos encontramos algumas fragmentos que se aproximam desse modelo, conforme abaixo:

E9.78 - porque é necessário haver um deslocamento dos postos dentro da família, e já se acomodou, e a areia já está acomodada ali, e eles preferem não mexer. Isso é interessante de se trabalhar, porque é um trabalho que a gente faz...

E9.80 - O mesmo preconceito que a gente tem encontra na sociedade, você também encontra na família com relação ao seu próprio irmão, filho, seja lá o que for, mãe que fala: ah fui sair com tal pessoa, que é o paciente digamos, e fala pra ele: só que você não fala nada, não faz nada e fica bem quieto, pra ninguém 
perceber que você é louco, entendeu? Então quer dizer, são coisas que a família não está ajudando em nada nessa parte.

A reabilitação como prática de natureza educacional, além de objetivar a diminuição de recaídas, pretende a melhora de diversas funções elementares como higiene e vestuário até as mais complexas como o trabalho, tendo como finalidade última a convivência adequada dos pacientes com suas limitações (Amiel, Gittelman, 1992 apud Amim, Silva Filho, 2000).

E9.62 (transformação na vida) - o próximo passo que eles costumam ter é em relação às vestimentas, então eles começam a se vestir melhor...

E11.62 - Começam a se arrumar, vão ao cabeleireiro, conseguem pagar uma manicure, se arrumar, cabelo, então muda roupa, então dá uma mudada assim muito grande.

A lógica deste modelo considera a reabilitação uma etapa final subordinada ao tratamento, uma vez que trata das conseqüências, do que vem depois da doença e dos sintomas (responsabilidade da terapia), e seu objetivo estaria relacionado à boa convivência do sujeito com sua doença e sua incapacidade (Castelfranchi apud Amin, Silva Filho, 2000).

E9.10 (proposta da oficina) - Então a partir do momento em que eles ingressam na oficina você consegue perceber que as crises diminuem, elas ficam mais passadas, quando elas vêm, elas são mais fáceis de lidar com a pessoa, e da pessoa lidar com ela mesma em crise.

E9.45 - E isso por um lado auxilia muito no próprio tratamento deles, porque existe uma troca interessante, existe um crescimento deles também como pessoa, de se aceitarem, de se respeitarem...

E5.26 - são os limites, é onde nas oficinas, a gente aprende a trabalhar com os limites, cada um tem um limite, você respeita o limite de cada um dentro da atividade que vai ser executada...

E5.27 - hoje não é tanto problema, mas assim, um dos problemas que a gente teve no início era mostrar pra cada um, que todo mundo pode fazer alguma coisa, mas cada um dentro do seu limite.

A articulação com o tratamento também está presente na proposta de reabilitação de Mark Spivak. O desenvolvimento das competências sociais do paciente, fundamento desse modelo, teria como finalidade a garantia de uma continuidade terapêutica.

E1.196 - É eu penso que uma política que deve ser ampliada, implementada, porque contribui com o tratamento. 
E6.57 - mas outras coisas estão acontecendo o tempo todo, então, eu acho que o terapêutico permeia o tempo todo, com o grupo.

Tendo como objeto a cronicidade psiquiátrica, a proposta de Spivak considera que a falta de competência da pessoa em satisfazer as suas próprias exigências e daquelas com quem interage resultaria na dessocialização e na progressiva diminuição da articulação social, a partir do distanciamento do paciente com relação às pessoas significativas e do autoisolamento (Saraceno, 2001).

E5.76 - Eu acho que é um dos maiores valores que a oficina consegue é essa interação deles.

E6.61- Às vezes as pessoas chegam lá, meio quietas, com uma história de doença de muitos anos e acabam se soltando mais, criando esse vínculo com o grupo...

Nesse sentido, a finalidade da reabilitação estaria relacionada à neutralização dos processos crônicos, especialmente quanto à interação social, por meio da avaliação das incompetências e do desenvolvimento de comportamentos socialmente competentes com objetivo de adaptar o funcionamento do paciente conforme as normas socialmente compartilhadas.

E11.64 - E são muitas, são muitas coisas assim que acontecem. De pessoas que mudam, pessoas que não saiam de casa pra nada, que ficavam o dia todo dentro de um quarto fechado, olhando pro teto, e de repente começa a sair de casa, pegar ônibus, a conviver mais com outras pessoas, que seja no ônibus, que seja na rua, que vai ter que fazer, tem uma melhora do seu quadro muito grande, de uma maneira muito bonita.

O modelo de Spivak enfatiza a dimensão interpessoal como base para a elaboração de intervenções ressocializantes, a partir da avaliação das deficiências particulares do indivíduo com seu meio, articulando cinco áreas: habitação, trabalho, familiares e amigos, cuidado de si e independência, atividade social e recreativa.

A interação trabalhador-paciente é compreendida como uma forma de mediação por atividade específica que permite a aprendizagem dos comportamentos socialmente competentes.

Nesse processo de aprendizado, os componentes de suporte teriam como objetivo a aceitação do paciente como ele é, demonstrada pela atitude de permissividade do trabalhador, independente das formas de seu 
comportamento. Por outro lado, a não confirmação das expectativas desviantes - sentimentos de impotência e fracasso -, bem como a recompensa dos comportamentos competentes seriam intervenções dirigidas à mudança do paciente para seu envolvimento em papéis sociais normais na comunidade externa, e também para redução de freqüência nos programas de reabilitação, mantendo essa experiência como um ponto de referência.

E1.172 - E aí esse contato do CAPS é até às vezes pra esclarecer qual que é o projeto terapêutico, que no caso, da construção, a maioria das pessoas são alcoolistas ou dependente químico então é sempre um processo de resgatar os vínculos com o trabalho, os vínculos familiares que estão destruídos, quando ele chega aqui pra gente, geralmente são aqueles que estão assim é com tudo detonado, ou está na rua, ou está em pensão porque não está com a família.

E9.70 - Como pessoa dentro de um planeta, Terra, e que ele tem um espaço, ele tem o direito de usar esse espaço, e ele tem a capacidade de usar, tanto quanto qualquer outro, e eles têm uma garantia de que tem alguém perto, pra hora que eles precisarem, que eles não souberem o que fazer, eles tem alguém a quem perguntar e a quem recorrer.

Contraditoriamente, essa ressocialização do indivíduo com o contexto, acaba resultando no desaparecimento do segundo termo, e, portanto, numa intervenção "só e exclusivamente na pessoa, no paciente, para readequá-lo de qualquer maneira e o mais possível às demandas e expectativas do contexto, o qual não é minimamente posto em discussão" (Castelfranchi, 1993 apud Saraceno, 2001, p.52).

O modelo de Spivak, por conseguinte, está focalizado na adaptação social do paciente às normas do contexto, que, todavia, não sofre nenhuma crítica no sentido de sua modificação para a proposta da ressocialização. Sendo assim, essa proposta alinha-se com a lógica médica, psiquiátrica sobre a reabilitação.

E10.13 - A reabilitação na verdade que eu estou querendo dizer, é uma forma do tratamento da doença...

A integração entre psiquiatria e reabilitação psicossocial também é defendida por autores como Bachrach (1992 apud Amin, Silva Junior, 2000), que considera um terreno comum entre elas. Nessa proposta de reabilitação, a noção de indivíduo é central, uma vez que esta pressupõe as 
necessidades particulares das pessoas. $O$ objetivo da reabilitação estaria relacionado à promoção da auto-estima e resgate da auto-confiança com relação as potencialidades produtivas.

O reingresso no trabalho como finalidade da reabilitação partindo da redução das incapacidade (evolução do conceito desenvolvido por Wing e Morris), diferenciadas em primária, mais ligada à patologia; secundária, relacionada à melhor compreensão da doença pelo paciente; e terciária ou social, na qual a melhoria da rede social, a redução do estigma e a legitimação do paciente em diversos contextos de vida, resultaria no objetivo final da melhoria da qualidade de vida.

As propostas reabilitadoras que se fundamentam na incapacidade, em geral, concebem esta última como uma condição permanente, na qual a intervenção deve propiciar o aprendizado ou reaprendizado dos comportamentos necessários à reintegração no contexto, este último considerado como um simples suporte da reabilitação, não sendo alvo, portanto, de questionamentos quanto aos comportamentos e papéis esperados pela sociedade.

E4.8 - ...vai aparecer aonde está o buraco, aonde ele está com o problema e aonde a gente pode estar ajudando.

Nessa concepção, o reabilitador deve então reconhecer sua relação com a psiquiatria, configurando a reabilitação como um apoio para sua prática. Os autores desse modelo defendem essa integração com o tratamento psiquiátrico na reabilitação, cujas práticas de natureza educacional visam, sobretudo, a melhoria do funcionamento social (Amiel, Gittelman,1992 apud Amin, Silva Filho, 2000).

\begin{abstract}
O objeto e razão de existir da reabilitação é a incapacidade. Reabilitar significa reduzir as possibilidades de recaída e superar um déficit crônico. A reabilitação depende do tratamento e desenvolve funções de apoio e complemento. A reabilitação pode contribuir para a eficácia de todas as terapias, sendo concebida como um prosseguimento, uma etapa sucessiva, uma estratégia a ser usada num segundo momento. (Amim, Silva Júnior, 2000, p. 118).
\end{abstract}

Os estudos sobre a cronicidade dos distúrbios esquizofrênicos, também influenciaram Luc Ciompi a refletir sobre a relevância dos processos psicossociais no resultado da reabilitação. Nesse sentido, Ciompi enfatizava o valor do prognóstico no sucesso da reabilitação, especialmente com 
referência as relações interpessoais no contexto de trabalho e as expectativas do futuro por parte do paciente, dos familiares e dos terapeutas.

E7.6 - ...é de tentar levar esse sujeito a se acreditar no que ele tem um potencial, que ele tem um lado que a gente pode resgatar e fazendo um trabalho no sentido assim, dessa assistência...

Os estudos desenvolvidos por Ciompi e colaboradores sobre a influência das expectativas na reabilitação, sobretudo de familiares e técnicos, revelaram a conexão entre as modalidades de estruturação e evolução do campo social no desenvolvimento das patologias esquizofrênicas crônicas, trazendo outras variáveis (campos, comportamentos, e funções) na conceituação do distúrbio psiquiátrico e no processo de intervenção (Saraceno, 2001).

Essa conceituação, por conseguinte, sustenta que as expectativas futuras de trabalho e de vida independente do paciente adquirem peso maior que as próprias intervenções dirigidas ao paciente, principalmente dos familiares e técnicos (Saraceno, 2001).

E6.63 - E acho que isso muda muito com as famílias. A gente já fez reunião de familiares, que eles trazem isso: nossa meu filho se curou depois que veio pra cá.

E3.74 - O retorno que a família dá, que os profissionais dos centros de saúde ou CAPSs dão.

A reabilitação neste modelo é entendida como um processo gradual, na qual se deve intervir, sobretudo, na modificação das expectativas dos atores envolvidos, na perspectiva da reinserção, mais completa possível, na vida social e produtiva normal (Ciompi e col., 1987 apud Saraceno, 2001).

E9.68 - E a última mudança mais, que demora mais tempo, e que você também consegue ver, é em relação à expectativa que a pessoa tem com relação a sua própria vida.

E9.69 - É uma pergunta que eles não fazem, e com o tempo passando na oficina, eles começam a arriscar coisas do amanhã, e depois começam a apostar no amanhã, e no fim, eles começam, alguns, a investir no amanhã

E9.79 - Você tem que colocar a família junto, mostrar, de preferência família acompanhar a evolução dele, pra não ser uma coisa tão chocante assim...

Embora o modelo de Ciompi enfatize a importância do contexto social na elaboração de programas de reabilitação, o campo social nos modelos apresentados fica circunscrito ao espaço micro-social onde o sujeito está 
inserido, cujas intervenções limitam-se à orientação das pessoas envolvidas no manejo das situações adequadamente, servindo como um referencial normativo para reinserção do paciente.

Partindo do pressuposto que a doença mental é resultante de uma incapacidade do sujeito em ajustar-se às demandas de seu meio social, em virtude de uma vulnerabilidade individual, a finalidade última dessas propostas reabilitativas converge para a adequação dos comportamentos e respostas do paciente no sentido de sua máxima integração aos papéis sociais. O contexto social configura um ideal de adequação, embora entendido como um dos elementos que interferem na evolução das doenças mentais, acaba por ser naturalizado como uma realidade incontestável, que não precisa ser problematizada ou criticada, e portanto, transformada.

E5.6 - Eu acho que a oficina é um meio. Ele vem se reabilita e deveria sair.

E1.198 - tem pessoas que lógico, eu entendo que estão aqui que estão participando por uma questão de passagem, eu acho que muitos alcoolistas se reorganizam, enfim ficam um período sem beber e conseguem retomar a vida.

As instituições psiquiátricas, embora tenham sido nos últimos anos alvo de questionamentos especialmente acerca de sua centralidade no tratamento da doença mental, ainda cumprem a função normativa de ordenar a desordem do louco, legitimando o seu papel social de controle dos desviantes e reproduzindo as regras sociais do mundo real, que justificam a exclusão do louco ameaçador como forma de proteção, mas também do louco como vítima da sociedade ameaçadora. Trata-se de uma ambigüidade e de círculo vicioso, onde a única alternativa do louco é a submissão a essa mesma racionalidade que tanto o exclui quanto o protege (Saraceno, 2001).

\footnotetext{
O doente mental, fechado no espaço apertado da sua individualidade perdida, oprimido pelos limites que the foram impostos pela doença, é forçado pelo poder institucionalizante da internação a objetivar-se nas próprias regras que o determinam, em um processo de aparvalhamento e de restrição de si que originalmente sobreposto à doença - não é sempre reversível (Basaglia,1964 apud Saraceno, 2001, p.62).
}

Nesse sentido, a função ordenadora da instituição manicomial se manifesta no espaço, no tempo, no conjunto de normas e de ritos que contêm naturalmente essa ordem, legitimando e reproduzindo a necessidade 
de adaptação social do doente mental para a manutenção da instituição (particular), expressão da organização social (totalidade). A reabilitação, portanto, teria como objetivo último a reinserção social dos indivíduos desviantes à ordem social, por meio de instrumentos de intervenção voltados à regulação da ordem institucional, seguindo a mesma lógica que predomina o tratamento, como uma continuidade deste (Saraceno, 2001).

E4.38 - Eu acho que não são duas coisas distintas o tratamento e a oficina é uma coisa só. É uma continuidade, uma dá continuidade à outra.

Logo, a utilização do trabalho nesses modelos, cumpre a mesma função ordenadora que traz em si a mesma ambigüidade da ordem do patrão e do pai, exercitando duas funções - paternidade e domínio - que excluem a hipótese da dúvida, e acabam por reproduzir a razão burguesa (Saraceno, 2001).

E1.190 - Ele tem um problema, está demenciadíssimo, tem um problema seríssimo de memória que está piorando muito, e ele fala que o monitor é o patrão, então assim é só como exemplo...

E7.100 - O X que está contratado, ele está trabalhando, aí de vez em quando ele vem aqui, ele chama a $X$ de mãe: cadê a mãe? Aí procura, e extremamente responsável, nunca mais fez uso de bebida.

Concluindo, esses modelos que se baseiam nas incapacidades decorrentes do sofrimento mental, apresentam o treinamento de habilidades como um processo gradual, no qual o paciente deverá aprender sucessivamente como comportar-se adequadamente, especialmente no interior das relações sociais de trabalho, conforme abaixo:

E4.24 - E assim ele vai aprendendo, sucessivamente, pra que ele possa depois estar apto, a ter aprendido todas as atividades, pra poder trabalhar, ser inserido novamente no mercado.

E11.7 - eu acho que a proposta principal é fazer com que esse grupo realmente possa se manter, dentro da oficina, de maneira saudável, com um relacionamento social de cada um assim legal, estável, e realizando, as suas atividades, diariamente.

Considerando que as incapacidades, as inabilidades, as faltas, sejam variáveis que determinam a desabilidade e cronicidade dos transtornos psiquiátricos, esses modelos propõem intervenções reabilitadoras de natureza terapêutica e pedagógica, que objetivam a redução ou eliminação de fatores que alimentam a vulnerabilidade individual, especialmente com 
relação à inserção produtiva. Portanto, acreditam que o treinamento de habilidades e de comportamentos adequados às expectativas sociais pode resultar na reinserção social, no sentido da adaptação social. Esses modelos, portanto, alinham-se ao paradigma psiquiátrico tradicional positivista que concebe a loucura como uma doença, cujas intervenções terapêuticas e reabilitadoras devem dirigir-se ao ajustamento social do indivíduo, onde a capacitação para o trabalho torna-se um instrumento pedagógico voltado à adaptabilidade social:

E10.14 (reabilitação como tratamento e capacitação) - muitas vezes quando a pessoa chega na triagem ou na própria internação, com uma dificuldade muito grande da inserção no mercado de trabalho, então a reabilitação seria estar ensinando uma nova atividade, um novo trabalho, ensinando um trabalho diferente.

E10.15 - Na verdade a culinária, muita gente escolhe acho que por ser uma coisa que a maioria sabe fazer, mexer com alimento, mas também estar aprendendo um novo trabalho.

E11.71 - Olha, já teve oficineiros que saíram, que é legal, porque a gente prepara essas pessoas, de uma certa maneira, pro mercado, com as regras, livro-ponto, horário de chegada, horário de saída, o relacionamento grupal, como trabalhar em grupo, a importância de prazo, entrega, qualidade, então essas pessoas lidam com tudo isso...

As limitações desses modelos são devidas aos impedimentos do modo de produção atual que não oferece oportunidades de inserção ao ciclo produtivo, dificultando a finalidade da reabilitação em reintroduzir os usuários ao mercado de trabalho formal e à vida normal. Entretanto, algumas frases evidenciam um alinhamento com a ideologia dominante que ocultando a realidade como determinada pelas formas sociais de exploração e de dominação política (Chauí, apud Barros, 2001), responsabiliza os indivíduos pelas dificuldades de inserção no mundo do trabalho formal:

E5.9 - A gente sabe que isso não é possível, mas se a oficina pudesse ter esse espaço de passar e ir pro mercado seria interessante.

E5.7 - O que a gente não consegue, é fazer que cem por cento saia...

Embora os discursos apontem identificações com os modelos adaptativos, constatamos a influência da proposta de reabilitação psicossocial como cidadania. 


\subsubsection{Reabilitação Psicossocial como Cidadania}

A proposta de reabilitação psicossocial dirigida à cidadania problematiza as variáveis dos programas reabilitadores, dentre eles, o sujeito ao qual se dirigem as intervenções, o objeto de trabalho. As informações acerca desse sujeito, na qual se poderiam identificar necessidades, demandas e possibilidades, em geral, são organizadas na forma de diagnóstico psiquiátrico que se refere essencialmente à condição psicopatológica, além de algumas informações sobre suas habilidades e seu contexto familiar. Essa necessidade do diagnóstico psiquiátrico que como vimos recorta a existência do sujeito em sua doença demonstra um alinhamento com a função ideológica de controle social, além de manter a unidade e identidade médica sobre outros saberes. Contudo, as pessoas reais bem pouco se adaptam às categorias psiquiátricas definidas pelo diagnóstico (Saraceno, 2001).

Sendo assim, a reabilitação psicossocial nessa nova orientação, deve considerar que as informações que o sujeito carrega consigo são um patrimônio e estão relacionadas à vida do paciente e não à sua doença, buscando portanto o re-encontro com essa existência, parafraseando Basaglia, colocando a doença entre parênteses.

E10.12 (reabilitação) - acho que é o trabalho, é a pessoa...

E7.30 - E quando você fala de reabilitação psicossocial, esse social é muito grande, porque o sujeito vem pra tua oficina, ele não vem só pro trabalho, ele traz a família, ele traz o vizinho, ele traz, começa o namoro dentro da oficina.

Nesse sentido, constatamos também a preocupação dos coordenadores com relação ao resgate do contato com o usuário, entendido como sujeito de razão, de necessidades, de capacidades, de direitos e de desejos:

E7.94 - essas são as possibilidades de resgate de sujeito, de vida, de sentido, de alegria, de querer, de fazeres...

E7.34 - Então, eu acho que essa situação, essa proposta da oficina é assim, é toda uma disponibilidade pra receber o sujeito e a partir daquela entrada pra dentro da oficina, de você encaminhar tudo na medida do possível que ele traz enquanto demanda, enquanto sujeito, no seu sofrimento psíquico, enquanto sujeito, cidadão quer readquirir aquilo que ele perdeu, ele precisa ser acreditado nisso. 
E7.50 - ela participou da oficina, ela tinha um sonho, queria, o sonho dela era fazer faculdade, a gente batalhou junto e conseguimos uma bolsa de estudo de técnica de enfermagem, ela faz técnica e hoje ela trabalha fora.

A reabilitação psicossocial que objetiva a elevação do usuário à condição de cidadão pressupõe a intervenção em três eixos principais: o habitar, a rede social e o trabalho. A rede social configura a possibilidade de estabelecimento de relações interpessoais que possibilitem um aumento da troca subjetiva e material nos contextos de vida real e não apenas restritos à instituição (Saraceno, 2001). Ampliar essa rede social torna-se, portanto, uma intervenção reabilitadora que visa à participação nas relações sociais, como se observa nas frases abaixo:

E5.23 - Também conseguem reestruturar suas relações afetivas e emocionais através da convivência com os outros oficineiros.

E5.74 - Nas oficinas eles se interagem com os outros oficineiros, criam redes de relações de amizades e vínculos afetivos, saem juntos nos finais de semana, se visitam em casa, se preocupam quando um oficineiro esta doente, ficam tristes quando morre alguém da família de um deles, participam de aniversário de filhos, almoçam no domingo na casa dos pais dos oficineiros.

E5.75 - eles têm uma rede muito grande de relações fora daqui. Então eu acho que isso é um ganho muito grande, além do dinheiro, essa relação, é esse vínculo que eles fazem entre eles é bem legal e bem interessante.

E5.73 - Então, eu acredito que as oficinas de trabalho são um grande ganho pra vida dos oficineiros, não somente no que tange à geração de renda, mas também na rede de relações sociais.

A autonomia dos usuários é compreendida como uma condição fundamental à desinstitucionalização e à cidadania, finalidade das intervenções reabilitadoras desinstitucionalizantes. Entretanto a referência à autonomia, em geral, está vinculada à idéia de capacidade singular dos sujeitos em participar vitoriosamente do jogo social, sendo assim a reabilitação referida à essa noção de autonomia busca o melhoramento dos atributos pessoais danificados. Na proposta de reabilitação voltada à cidadania, a autonomia vincula-se à participação dos sujeitos de maneira equivalente, modificando as regras do jogo, "de maneira que desse participem fracos e fortes, em trocas permanentes de competências e interesses" (Saraceno, 2001, p.113). 
$\mathrm{Na}$ análise dos discursos, identificamos a noção de autonomia referida à modificação do papel social por meio das relações estabelecidas no processo de produção da oficina, na qual se estimula a solidariedade e a cooperação entre os participantes, como verificamos a seguir:

E2.29 - Começa a fazer uma rede de convivência de contato, criar ou ter mais autonomia e ter assistência e o cuidado, da gente, que estar sempre com eles, do próprio grupo, que às vezes um auxilia o outro.

E8.36 - Porque vai amadurecendo, vai ocupando um outro espaço na sociedade, ganho de autonomia, que é inverter o papel do cidadão.

E7.9 - dessa produção a gente vai trabalhando autonomia, cidadania, direito, convivência, solidariedade que não são coisas muito simples assim...

A cidadania, como uma finalidade da reabilitação psicossocial, não pode ser entendida como simples restituição de direitos, mas como reconhecimento do usuário como sujeito de razão e de vontade, respeitando suas diferenças (em contraposição a conceito liberal da igualdade) e promovendo sua participação em contextos de vida real (Oliveira, 2004).

E7.39 - uma grande arte é você lidar com as diferenças, e aí você fazer também uma avaliação do que ele consegue produzir, lidando com as diferenças, tentando manter a cidadania que é um direito, tentando valorizar que ele tem uma possibilidade de aprender, mas ele tem um limite.

E7.40 - Como você avaliar o processo de aprendizagem dentro de um processo de trabalho, cuidando dessa diferença.

E6.6 - Porque ele era alguém que já sabia bastante coisa, que tinha, já tinha trabalhado com a questão de eletricista, assim, então ele pegou essa função na oficina, que era uma coisa que ele desempenhava bem, que ele gostava. Aí depois, acho que ele ficou dois anos na oficina, e depois desses dois anos ele conseguiu um emprego, estar trabalhando fora assim.

A relação entre cidadania e saúde mental foi estudada por muitos autores do campo da reforma psiquiátrica brasileira ${ }^{29}$, que discutem a existência de uma concepção liberal da cidadania nos discursos antimanicomiais, propondo uma superação desse conceito, na qual a cidadania está associada apenas à melhoria da assistência (humanização), para mudanças mais profundas nas relações sociais, dirigidas à construção

${ }^{29}$ A esse respeito, ver Birman (1992), Bezerra Jr. (1992) e Delgado (1992). 
de um novo lugar social/ cultural para o sofrimento mental. Essa necessidade de reformulação da cidadania aparece nos fragmentos a seguir:

E3.38 (transformação na vida)- ...e a efetiva reabilitação psicossocial, resgatando o convívio social, sua posição na sociedade, com voz, com direito entre todos.

E7.11 - E todo um trabalho, no sentido assim, de tentar, porque ele já tem história da evolução da psiquiatria, ele já era sempre o excluído que tinha que ser retirado da convivência porque ele atrapalhava.

E11.66 - E pessoas que tiveram a vida transformada ali de pouquinho em pouquinho, e que hoje conseguem falar, conseguem até mesmo brigar por uma melhor bolsa, exigir mais, fazem cobranças, que conseguem lutar pelos seus direitos que conseguem fazer mais exigências, até mesmo dentro de sua casa, conseguem se colocarem mais, então, é uma transformação assim gradual, mas que acontece.

Essa transformação do papel social, finalidade da reabilitação social, é compreendida pelos entrevistados, como uma mudança cultural sobre a capacidade produtiva das pessoas com sofrimento mental por meio da produção nas oficinas:

E4.30 - Porque hoje em dia nós não somos vistos mais como: Ah vamos dar um serviço pro coitadinho, pro louco.

E7.12 - Então, assim, poder ofertar que existe uma possibilidade de que ele se sinta melhor com isso que foi colocado pra ele. Que ele consiga ver, que ele possa se apresentar de uma outra forma, através da produção, de um fazer...

O reconhecimento como sujeito produtivo e responsável nas relações sociais, em especial nas relações familiares é apontado como uma proposta reabilitadora, coerente com as necessidades dos usuários. Nesse sentido, a intervenção reabilitadora concebe o sofrimento mental não mais como sinônimo de incapacidades e incompetências, que geram uma vulnerabilidade individual e aprofundam a cronicidade da doença mental.

Logo, essas dificuldades ou desabilidades devem ser contextualizadas, e o efeito habilitador só pode ocorrer no interior das dinâmicas relacionais. Sendo assim, as intervenções reabilitadoras são entendidas como conjunto de estratégias orientadas a aumentar essas oportunidades de troca, a promover "a abertura dos espaços de negociação para o paciente, para a família, para a comunidade circundante e os serviços 
que se ocupam do paciente" (Saraceno, 2001, p.113). As frases a seguir revelam a identificação com essa proposta:

E8.35 - Ah possibilidades de crescimento, do oficineiro ser reconhecido, de poder sustentar a própria família, reconhecer a paternidade de uma filha, que isso se deu dentro de uma oficina.

E9.67 - Então a família dá bastante esse tipo de retorno pra gente.

E7.83 - Como que eles são voltam pra família, inseridos de uma outra forma, aqueles que eram problemáticos, passam até a ajudar na casa.

Nessa perspectiva, o trabalho não é considerado como recurso normativo que visa à adaptação social, mas um instrumento que permite o resgate ou a consciência da capacidade produtiva, negando, portanto, o paradigma psiquiátrico que promoveu o estatuto de incapacidade e utilizou o trabalho, valor moral de condenação à ociosidade, com o propósito de reeducação às normas sociais e de exploração da força de trabalho no interior das instituições psiquiátricas.

E7.86 - Então assim, o resgate da auto-estima, dessa capacidade de produção, de uma outra inserção dentro da família, dentro da comunidade.

Entretanto, o que permite essa transformação do sentido do trabalho na reabilitação social em contraposição à ideologia do trabalho no tratamento moral (terapia, norma moral, entretenimento, exploração da mão de obra), e também às modernas técnicas de reabilitação que em síntese propõem a substituição da desabilidade pela habilitação, por "novas e refinadas técnicas de adestramento ao trabalho" (Saraceno, 2001, p. 79), está relacionado à inversão proposta pela desinstitucionalização, que afirma a possibilidade da troca de oportunidades materiais (direito ativo ao exercício do mercado) como condição primordial de exercício do direito à relação: o negócio precede o ócio.

E6.59 - A gente vê que tem pessoas que falam: ah depois que eu entrei na oficina minha família passou a me ver de outra maneira, antes eu era um doente, hoje eu sou um trabalhador, hoje eu sou o provedor até da minha casa, eu ajudo nas despesas, posso comprar minhas coisas.

E1.201 - a gente fala ah oficinas de trabalho, a maioria das pessoas que vem pro projeto, que às vezes estão há mais tempo, ficam bastante tempo, eles saem de casa e vem pra trabalhar. 
E7.87 - Muitos deles não falam que eles são pacientes, eles falam que, veio pra trabalhar, que são oficineiros, entendeu? Então é uma outra inserção, um outro sentido de vida pra eles.

E11.58 (transformação na vida) - Amplia totalmente a rede social dessas pessoas, começam a contribuir com a conta de água, de luz, ao qual muitos eram considerados pela família assim, ah esse daí...

E11.59 - É um peso não contribui em nada, quantos falam que não existe assim, ah minha família acha que eu sou um imprestável ou que eu não sirvo pra nada. E quando começa a trabalhar que começa a ajudar financeiramente, ajuda pra caramba.

Esse aumento real da contratualidade dos oficineiros, isto é, a possibilidade de posse de recursos para trocas sociais e, portanto, para a cidadania social, por meio do trabalho nas oficinas, também opera uma transformação no uso do trabalho pela psiquiatria tradicional, especialmente no trabalho desvalorizado e não remunerado. O trabalho concebido não apenas como resposta à necessidade, mas como espaço de produção de sentido e valores subjetivos e de troca (Saraceno, 2001) é evidenciado pelas frases como um instrumento de reabilitação capaz de transformar a identidade e a vida concreta do usuário:

E7.99 (usuária na reunião) - aí ela traz aquelas questões assim de uma clareza de quem, quero saber, qual é o meu direito. Então isso assim, é uma transformação na vida mesmo.

E11.65 - Falas assim: ah, eu não era ninguém antes, agora eu pareço gente, agora eu sou uma pessoa mais importante, me sinto mais feliz, mais realizado.

E7.95 (transformação na vida) - frases dos pacientes assim: agora posso comprar a televisão pro meu filho, coisas assim.

E11.56 - Porque a gente recebe pessoas que tinham perdido totalmente o contato com regras, a importância de realizar algo e ser valorizado, de poder contribuir dentro de um orçamento familiar, de poder pagar um cinema, poder ir numa lanchonete ou qualquer coisa, assim, que pra gente é tão comum e normal, mas que pra muitas dessas pessoas não era mais. Só tinham contato com o grupo de atendimento e tudo mais, uma vez por semana ou mais.

E1.193 - Eu acho que ela dá esse suporte e é um espaço importante. E acho que a geração de renda, que ajuda nas trocas sociais, na circulação na sociedade enfim também são possibilidades sem tamanho.

Nesse sentido, na análise temática pudemos identificar a aproximação das concepções dos entrevistados com a proposta de reabilitação psicossocial que objetiva a transformação da vida material e 
subjetiva dos usuários, a partir da promoção da autonomia e da capacidade produtiva que, por sua vez, desenvolvem o protagonismo dos sujeitos:

E9.60 - você vê que estão vindo assim, sem noção, às vezes sem um suporte necessário da família, então com muito poucos recursos de tomar conta de si próprio e talvez até de se reconhecer como sujeito.

E9.66 - então assim, muda o referencial deles, eles passam a fazer parte de uma história, onde eles também são personagens. $E$ parece que eles se enxergam dessa forma também.

E9.72 - pra chegar onde está agora que é o fato assim de falar: eu estou guardando dinheiro pra comprar uma casa, ou assim vou por uma dentadura, porque eu espero arrumar um namorado, porque talvez fique mais fácil de arranjar um namorado, posso arrumar um emprego melhor, posso arrumar qualquer coisa, e assim, vou por uma dentadura porque eu mereço mesmo, entendeu? Eu posso, eu quero e eu vou fazer, e pronto.

E7.98 - Tem o jornal Candura que eles fazem um trabalho, tem a rádio, então se apresentar de uma outra forma, de um outro sentido.

Esse protagonismo também se verifica na ampliação do repertório de interesses dos usuários que se traduz também no aumento e diversificação da linguagem e da comunicação, enriquecendo tanto suas capacidades e conhecimentos quanto suas relações interpessoais, conforme frases abaixo:

E9.63 (transformação na vida) - começam a comer um pouco melhor, começam a ter prazer em certas coisas, pensar em outros assuntos...

E9.64 (transformação na vida) - passam a ter outro vocabulário, a facilidade com que pode ser inserida a conversa empresarial com eles é muito interessante, porque rapidamente ele começam a falar em termos de números, de valores, o que menos tem noção, também fala com outras palavras a mesma coisa: nós trabalhamos tanto e eu ganhei tão pouco; quer dizer, alguma coisa ele está captando.

E9.65 - E há uma mudança grande também que a gente observa através do relato da família, que quando as pessoas chegam em casa, no final do dia, antigamente eram pessoas apáticas, que falavam assim: tomei meu remédio, não tomei meu remédio, estou passando bem, estou passando mal, e agora já vem com um outro tipo de abordagem em termos de cores, de novidades, de festas, de passeios, e fala: ah fui no cinema assisti um filme, e a gente fez uma peça, hoje a gente está introduzindo uma cor nova na oficina, trabalhava com tantas cores...

E9.73 - Então essas descobertas deles no dia a dia, é muito enriquecedor pra gente, cada vez que eles tem essa percepção e verbalizam isso de alguma forma ou externalizam é bastante interessante, eu acho que vale a pena todo o esforço. 
Entretanto, o lugar onde se realizam os programas reabilitadores, configura uma das variáveis fundamentais à qualidade do serviço cuja finalidade do processo de trabalho é a reabilitação psicossocial. Logo, o serviço deve caracterizar-se pela multiplicidade de lugares/oportunidades comunicantes e pelo intercâmbio de recursos que devem estar disponíveis tanto aos usuários quanto aos operadores. Além das pessoas (usuários, familiares e operadores) consideradas como recurso do serviço, outro recurso importante para os programas de reabilitação é a comunidade, concebida como "uma fonte inexaurivel de recursos existentes e potenciais, tanto humanos quanto materiais" (Saraceno, 2001, p. 101).

Sendo assim, evidenciamos uma contradição entre os dois lugares onde se realizam as oficinas de trabalho do serviço - o serviço de saúde e a loja -, que repercute na visão e no comportamento dos oficineiros. $O$ fato de algumas oficinas de trabalho funcionarem no espaço do hospital, antigo manicômio, que se localiza distante do centro da cidade, mesmo após o processo de reformulação da assistência, pode resultar numa resistência desse usuário em freqüentar esse espaço, identificado ainda como um lugar de internação, de violência, de isolamento e de exclusão. As marcas dessa segregação e estigmatização permanecem vivas na história das pessoas com sofrimento mental, embora os espaços físicos tenham sofrido alterações, como observamos nos fragmentos abaixo:

E8.42 (espaços de produção) - Porque lá ainda tem a cultura do hospital, do antigo manicômio, eles carregam muito dessas experiências, os espaços em que era a internação, onde eram trancados.

E8.43 - Têm muitos aqui que nem chegaram a passar por esse período, por essa fase, antes da reforma psiquiátrica, mas vivenciaram em outros hospitais, de serem trancados, super medicados, por uma violência.

E8.44 - E eles têm trauma e eles enxergam ainda o Candido como esse espaço, embora mudou muito os espaços, principalmente o modo de tratar, de ver as pessoas, mas eles não aceitam, porque tem essa cultura, tem o espaço, os prédios estão lá construídos, as coisas não mudaram totalmente.

E8.45 (espaços de produção) - Eles passaram a se vestir melhor quando vieram pra cá, se comportar melhor, mudou a postura. 
A possibilidade de circulação em outros lugares da cidade, "em cenários de vida reais, onde se trabalha, se ganha, se troca e se consome" (Saraceno, 2001, p. 141) permite a desidentificação da vida com a doença e, segundo os fragmentos de texto, uma maior valorização dos oficineiros em relação aos seus aspectos saudáveis:

E8.40 - E vindo aqui pra loja então, por que até então a gráfica o pessoal todo funcionava lá em Sousas, o evento foi criado aqui mesmo. Eu acho que deu outro status pra eles, porque antes eles iam pro Cândido Ferreira em Sousas, no serviço de saúde, trabalhar, hoje eles vem pra loja, pro Armazém das Oficinas na região do Cambuí, que é uma região nobre de muito comércio bonito, então acho que tudo isso é resultado positivo, acho que está valorizando o oficineiro.

E4.57- E uma coisa bem importante também dentro da oficina, que eu gosto muito de lembrar é que a gente trabalha também a saúde deles, e não partindo do princípio que eles são doentes.

E4.58 - Então a gente trabalha assim a saúde, o que é possível ele fazerem? E não com o que não é possível eles fazerem, entendeu? Então eu acho que fica mais fácil, eu acho que eles se valorizam mais.

E4.59 - então é a valorização do que eles tem de bom.

Essas intervenções promovem também a redução do impacto do sofrimento mental na qualidade de vida dos usuários e a reconstrução de suas histórias de vida, finalidades da reabilitação psicossocial pelo trabalho, identificadas nos fragmentos abaixo, que se alinham à proposta de reabilitação psicossocial voltada à desinstitucionalização:

E4.60 - Porque a doença, querendo ou não, já tem um médico, já tem um terapeuta, que tenta amenizar os sintomas da doença. Mas é que a gente também tem a possibilidade de trabalhar com a saúde deles, a melhora da qualidade de vida deles.

E7.93 (usuário que se cortava com os vidros) - ...eu pego na oficina eu lembro de você, eu pego no vidro eu lembro de você e aí eu não quero me cortar.

E7.101 - Não tem mais sentido, muda, eu não preciso mais porque tem outras coisas foram colocadas pra mim, não é mais os sintomas...

E7.96 (transformação na vida) - Primeiro eles trouxeram a historia de vida deles, então primeiro eles só contaram quem eles eram. Depois, aí eles conseguiram contar como que era estar na oficina, quando eles conseguiram falar deles na oficina, da profissão, de ser, ela foi tendo uma evolução. Aí eles iam, falavam, de sair daqui pra um trabalho, eles falavam do medo, como é que eu vou me comportar numa entrevista, como é que eu vou estar, como é que eu respondo, como é que eles vão me olhar? 
O conceito de reabilitação, ao longo do tempo, adquiriu significações diferenciadas e complexas. Devem estar presentes diversos níveis de ação, mas confluindo para emancipação e promoção de autonomia pessoal, caso contrário, a reabilitação é mistificação (Rotelli apud Barros, 1994).

A noção de reabilitação utilizada no processo de desinstitucionalização italiana relaciona-se à reconstrução das histórias de vida, buscando a recuperação ou a criação de vínculos e condições materiais, sociais e emocionais, possibilitando portanto a ruptura da lógica da reprodução da dependência. "Trata-se de encontrar soluções concretas para cada indivíduo, uma vez garantidos seus direitos essenciais como moradia, liberdade e trabalho" (Barros, 1998, p. 94-5).

\section{2. TRABALHO E DESINSTITUCIONALIZAÇÃO}

Para os reformistas italianos, o tema do trabalho foi fundamental ao processo de transformação tanto do aparato manicomial quanto da desinstitucionalização e da reinserção social. $O$ trabalho sempre foi central nas instituições psiquiátricas, como já vimos, entretanto com finalidades terapêuticas e de exploração. No processo de transformação da lógica manicomial, a questão central se tornou a superação do uso da atividade como ludoterapia, ergoterapia, tratamento moral, que se justificavam a partir do valor educativo, moral e social (sem ser econômico) bem como pelo afastamento dos pensamentos mórbidos pela ocupação, combatendo a inércia e o vazio responsáveis pelo isolamento da pessoa às suas idéias doentias (Barros, 1998).

A ergoterapia de Herman Simon propunha um sistema de reeducação por meio do trabalho-ocupação que tanto contribuía com a manutenção da instituição como determinava uma relação de dependência e objetivação. $O$ trabalho, portanto, era utilizado com essa dupla finalidade: a manutenção da instituição pela exploração e uma forma de re-educação às normas do mundo externo, configurando-se, portanto, como um critério de avaliação da evolução da doença, ou seja, um critério de cura e um critério de alta (Barros, 1998). 
No entanto, o trabalho, nessa lógica institucional, não apenas serve ao paciente como também age contra ele, uma vez que ao fazê-lo trabalhar a instituição também se beneficia desse trabalho, e sendo assim continua a segregar o paciente, impedindo seu retorno à vida normal (Zadini, Debernardi, 1973 apud Barros, 1998).

\begin{abstract}
A ergoterapia, apesar de sua filosofia originária delinear os objetivos 'terapêuticos', nas instituições se transformava em trabalho alienado (não reconhecido e não pago), sobretudo lá onde era indispensável à reprodução da própria instituição. Kleinmeier afirma que, nos EUA, até 1960, 'trabalhadores-chave' não eram demitidos, porque assim, bem 'reabilitados' pela terapia ocupacional, eram mais úteis no manicômio que fora (Saraceno, 2001, p.133).
\end{abstract}

Dessa maneira, a passagem da ideologia ergoterápica em direção ao exercício da cidadania, necessariamente passa pela problematização do sentido do trabalho nas propostas reabilitadoras, que, no entanto, não se configura num processo evolutivo linear, mas num processo dialético de avanços e recuos, carregado de conflitos e contradições.

\title{
4.2.1. Trabalho Normatizador (alienado)
}

Embora, o tema trabalho, na maior parte dos textos discursivos alinhe-se à concepção da reabilitação psicossocial como cidadania, encontramos contradições e falta de clareza conceitual em relação ao sentido do trabalho, que não desvalorizam o projeto das oficinas de trabalho, mas apenas confirmam a teoria marxista com relação à unidade e luta dos contrários, que caracteriza os movimentos de mudança em direção a uma nova forma. Nesse caminhar dialético, elementos da velha forma não desaparecem simplesmente, mas é sobre essa base que se constrói o novo, portanto, essas contradições não impedem ou negam o movimento, ao contrário, fazem parte indissociável desse processo de transformação que, no entanto precisam ser superadas por um salto de qualidade.

Além do mais, essas concepções estão coerentemente fundamentadas na missão institucional do serviço, cujos objetivos relacionam-se com a reabilitação psicossocial, por meio da geração de renda e capacitação profissional, sem desconsiderar as questões 
terapêuticas, que são assistidas também pela equipe de profissionais da saúde mental.

Dessa maneira, o sentido da utilização do trabalho nas oficinas do NOT, corrobora com as concepções apontadas anteriormente sobre a reabilitação psicossocial, sendo apresentado pelos entrevistados com variadas significações.

Em primeiro lugar, encontramos frases em que a utilização do trabalho foi associada à intervenção terapêutica, uma vez que o espaço onde se realiza a produção da oficina é também definido como um setting terapêutico, protegido e acolhedor, como se vê nas frases abaixo:

E1.203 - então acho que isso viabiliza também isso, que ao mesmo tempo que a gente procura ser um espaço também acolhedor, de tratamento. A gente tenta o tempo todo deixar claro que aqui é o espaço de trabalho também, então assim tem demandas que a gente não acolhe na oficina, vai pro seu espaço de tratamento, psicoterapia, aqui é o espaço de trabalhar...

E7.97 - Porque aqui eu sei como vocês me vêem, o grupo, como é que eu estou aqui, como que a gente está, mas lá fora não é assim. Então de poder falar disso, de poder lidar, de situar de uma outra forma.

Em outros fragmentos, o trabalho, dentro desse espaço mais protegido, foi associado a uma intervenção "curativa" que possibilitaria uma melhora da doença mental, e consequentemente, uma redução do número de internações, como depreendido das frases a seguir:

E6.66 - E muitos deles já saíram, foram pro mercado de trabalho, outros estão na parceria, outros continuam lá, mas você vê que não internaram mais, que conseguiram estabilizar assim, que estão bem mesmo assim.

E11.11 - a gente vê pessoas que antes tinham assim, internações constantes, internações direto, uma presença mais diariamente aonde elas faziam atendimento, e a partir do momento que você começam a ter essa relação de trabalho diário e tudo mais, isso diminui..

O trabalho, nessa mesma lógica, possibilita a convivência entre iguais e a circulação em outros espaços, entretanto restritos às relações e aos espaços institucionais como se infere das frases abaixo:

E4.7 - Então eu acho que diariamente nós temos situações assim, do convívio social mesmo deles, onde aparece muito a proposta do trabalho que é onde a gente pode estar ajudando eles. 
E11.57 - E quando essas pessoas começam a trabalhar, e só o fato de já vim pegar um ônibus diariamente, vir pra cá, ter contato com um grupo de pessoas totalmente diversificado.

Nessa perspectiva, o trabalho aparenta ser sinônimo de atividade e de ocupação, cuja finalidade terapêutica associa-se ao estabelecimento de hábitos e rotinas disciplinadoras, considerados necessários à convivência adequada e ao respeito às regras sociais, como verificado nas frases abaixo:

E2.27 (transformação na vida) - Pelo que a gente vê aqui no dia a dia, é um desenvolvimento de atividade.

E3.12 - porque muitos perderam o hábito do trabalho, outros nunca adquiriram, sempre, não tendo horários pra levantar e tudo mais.

E2.4 (cotidiano) - horário das atividades as tarefas desenvolvidas, o trabalho em grupo, o horário de descanso entre as atividades que proporcionem satisfação entre os oficineiros, como o café da manhã também e o horário de almoço.

E11.10 (proposta da oficina) - conseguir inserir elas dentro da oficina de trabalho, onde vão ter contato, novamente toda com uma estrutura de trabalho, regras, relação social, conseguir com que essas pessoas possam ficar dentro desse espaço de maneira saudável, organizada, e que se sintam bem, como acontece com a maioria...

A questão do hábito do trabalho é discutida por Marx (1890) como um elemento do processo de acumulação primitiva, que possibilitou o desenvolvimento do modo de produção capitalista. Segundo o autor, no processo de expropriação e expulsão da população rural, surgiram algumas legislações que combatiam a vagabundagem, buscando enquadrar os indivíduos na disciplina exigida pelo sistema de trabalho assalariado. A princípio, empregou-se um "terrorismo legalizado" (Marx, 1890, p.854) de açoitamento, de marcação com ferro em brasa e de tortura.

Com o tempo, esses mecanismos de repressão e condenação à ociosidade que impediam a venda livre da força de trabalho, foram se diluindo e com a progressão da produção capitalista, "desenvolveu-se uma classe trabalhadora que por educação, tradição e costume aceitava as exigências daquele modo de produção como leis naturais evidentes" (Marx, 1890, p. 854).

A organização do processo de produção capitalista em seu pleno desenvolvimento quebra a resistência dos trabalhadores, naturalizando esse modo de produzir e suas regras, criando, portanto, um hábito, um costume, 
uma educação que serve para subordinar de forma sutil, sem o uso da força, os trabalhadores, que sem outra alternativa de sobrevivência, precisam vender sua força de trabalho ao capital, acabando por aceitar suas relações de produção como naturais. Tanto essa coação surda quanto a superpopulação relativa que mantém a lei da oferta e procura de trabalho, e, portanto, o salário em harmonia com as necessidades de expansão do capital, consolidaram o domínio do capitalista sobre o trabalhador (Marx, 1890).

Sendo assim, o hábito do trabalho pode ser entendido como forma de normatização, de adestramento, de subordinação ao modo hegemônico de produção e às regras das relações sociais de trabalho.

No campo da saúde mental, essa mesma lógica moral de condenação à ociosidade e de controle e disciplina pelo trabalho segundo as normas sociais, fundamentou o chamado tratamento moral, que como abordamos anteriormente, servia muito mais ao manicômio e à ordem social do que ao paciente, este explorado e oprimido pela obrigatoriedade do trabalho institucional, que tinha uma função moral, pedagógica e terapêutica (no sentido da normatividade). As frases abaixo demonstram uma aproximação com esse paradigma:

E2.28 - sair do ócio, que às vezes tem oficineiro que a gente escuta assim que não saia de casa, que só ficava deitado o dia inteiro, comendo ou que não conversava com ninguém.

E7.82 - Isso é impressionante, assim, como que é tem um valor pra eles, um compromisso com o horário, um compromisso com o fazer, um compromisso com estar aqui, mas assim, você precisa de trabalhar a relação para poder ter isso.

Não se trata de negar o valor do trabalho para o sujeito, e seu efeito central na vida, porém este não pode ser associado à disciplina e ao controle para a manutenção da ordem social, mesma lógica que justificou o isolamento e exclusão da loucura como antônimo de produtividade. Nesse sentido, o valor do trabalho parece estar em si mesmo, como cifra do valor das pessoas. Nessa perspectiva, somente o fato de trabalhar já indicaria uma melhora do sujeito, coadunando com o valor ético e moral do trabalho, e desconsiderando o sentido desse fazer para o sujeito e as circunstâncias na qual se realiza esse trabalho. O sentido do trabalho nessa lógica é similar 
ao tratamento moral, que como vimos o trabalho era considerado critério de diagnóstico, era utilizado como terapêutica no sentido da adaptação social, que resultaria por sua vez num critério de cura e de alta, quando o sujeito disciplinado, controlado e educado para o trabalho poderia regressar ao convívio social e ao mundo produtivo.

Entretanto a inclusão no mundo do trabalho tornou-se uma tarefa complexa, visto que cada vez mais parcelas significativas da população são alijadas do ciclo produtivo, seja por não conseguirem entrar na normalidade de uma vida de trabalho ordenada (Leonardis, Mauri, Rotelli, 1995), seja pela drástica redução dos postos de trabalho que assistimos na atual crise do capital.

E4.26 - Mas a gente percebe que, o mercado ele não absorve. Nem as pessoas ditas normais, tanto as pessoas que tem algum tipo de problema mental, de saúde mental.

Entretanto essa limitação do mercado de trabalho formal, que abordamos anteriormente, parece ser entendida apenas como uma restrição individual à reinserção no mundo do trabalho, amplificada para as pessoas com sofrimento mental, desconsiderando a totalidade da questão do trabalho na sociedade capitalista, na qual a crise de acumulação vêm se traduzindo na precarização das relações de trabalho para ampliação da mais valia e garantia dos lucros do capital. Esse fenômeno cíclico do modo de produção capitalista com relação à superpopulação relativa torna essencial a existência de uma reserva de mão-de-obra para baixar os salários e aumentar a jornada, e assim, elevar a exploração da classe trabalhadora.

Logo, o ocultamento dessa dimensão estrutural do trabalho se traduz na permanência da valorização do trabalho assalariado como um objetivo a ser atingido pelas intervenções assistenciais, na qual a inserção no mercado de trabalho formal torna-se um resultado desejado, como se vê nos fragmentos abaixo:

E7.91 (usuário que usava álcool) - Tem pessoas que estão contratadas na oficina. Hoje está contratado, ele conseguiu superar...

E7.90 - isso é de uma riqueza muito grande de ser contratado, de você trabalhar na home care na UNIMED...

E5.4 - Então acho que era mais legal assim que é casos de sucesso, têm alguns outros que estão inseridos no mercado de 
trabalho, mas eu acabo acompanhando por no máximo quatro meses..

A análise temática permitiu identificar ainda uma concepção de trabalho protegido, na qual o espaço institucional seria mais tolerante às características do sujeito com sofrimento mental do que o mercado de trabalho formal, como se vê nas frases abaixo:

E11.63 - Então essas transformações que são legais, com esse grupo de pessoas que começam a trabalhar dentro desse espaço mais protegido.

E11.72 - ...dentro da oficina de trabalho, mas elas se sentem mais protegidas aqui.

Essa questão do trabalho protegido ou assistido não é uma simples caracterização dos projetos de trabalho, mas uma forma de entender o trabalho do ponto de vista da assistência, ou seja, a partir dos serviços, que atualmente pode apresentar-se de diversas maneiras: 0 trabalhoestacionamento das oficinas protegidas, onde se trata de passar o tempo com alguma atividade artificial, separada da vida real, que infantiliza as pessoas; o trabalho-prêmio, para quem consegue e merece participar de um programa de reabilitação; o trabalho-normal e normativo, das inserções laborais; o trabalho-pedagógico, como terapia de normalização; o trabalhosolidário, de certas cooperativas que reproduzem vínculos de lealdade; o trabalho-ocupacional, que reduz o trabalho ao posto e a auto-estima à honesta fadiga pelo salário (Leonardis, Mauri, Rotelli, 1995).

Todas essas formas de trabalho assistido são compatíveis com a lógica do mercado na sociedade, onde predomina o valor do trabalho em si e na qual as relações de produção estão subordinadas ao modo de produção capitalista. Nesse sentido, a organização da produção nas oficinas baseia-se também nos modos de produção social, reproduzindo o trabalho como produção de mercadorias vendáveis, baseado na divisão social do trabalho, configurando-se em trabalho alienado.

E9.47 (possibilidades) - E outro ponto é a gente trabalhar a produção, a organização da oficina como se fosse uma pequena empresa mesmo.

E9.48 - Às vezes nem tão pequena assim, porque gira muita peça, muitos itens, muito dinheiro, muito pedido, muita, muito trabalho.

E2.37 - A gente funciona como um restaurante comercial, aqui dentro, se quiser vir uma pessoa de fora comer, funciona assim. 
E2.56 - a gente tem uma rotina de trabalho-trabalho, porque não tem como fugir disso, porque têm que entregar refeição, eles tem que ter higiene.

A alienação como vimos é resultado das relações que se estabelecem no modo de produção capitalista, manifestando-se no tipo de relação que o trabalhador estabelece com o produto de seu trabalho (q se mostra estranho a ele e o domina) como também no interior do processo de trabalho, cujo parcelamento também divide os indivíduos que isolados se vêem alienados da natureza, de si mesmos, de seu ser genérico e do homem ${ }^{30}$ (Mângia, 2003).

Nesse sentido, a alienação, termo emprestado de Pinel, corrobora com o isolamento social dos sujeitos individualizados, que se vêm responsáveis pelo seu sofrimento, devido a sua doença ou incapacidade, desconsiderando que as razões dessa exclusão social não são naturais, mas determinadas historicamente.

\subsubsection{Trabalho Reabilitador (Emancipado)}

Nas propostas reabilitadoras que tem por horizonte a desinstitucionalização torna-se essencial questionar os valores institucionais e transformar as representações sociais sobre o sofrimento mental com relação ao estatuto de incapacidade e periculosidade. Trata-se de restituir ao sujeito o direito à subjetividade e à autonomia, por meio da validação de sua potencialidade produtiva, enfatizando aquilo que a pessoa pode fazer (Barros, 1994). As frases a seguir confirmam essa finalidade:

E2.33 - é uma valorização deles, como pessoas.

E6.16 - Tem gente que está há 10 anos na oficina, e que lá é o lugar dela, lá é o trabalho dela, é o que ela gosta de fazer.

E3.36 (transformação na vida) - Assemelha-se ao ser humano que descobre o mundo do trabalho, o efeito pra estima, pra auto-estima, autoconfiança, o prazer da produção, da remuneração, da igualdade frente à família.

E4.51 - Porque a partir do momento que ele vem pro NOT, que ele tem um horário pra entrar, um horário pra sair, que ele é tratado

${ }^{30}$ A esse respeito ver Mângia (2003). 
como um trabalhador, com dignidade, dentro das capacidades dele, a gente respeita os limites. Então eu acho que isso já é um ganho enorme.

Nesse sentido, o trabalho também é apontado como uma possibilidade de transformação da identidade de doente para trabalhador, no sentido da mudança do papel social, que segundo os discursos, é objetivada pela produção de peças e prestação de serviços de qualidade, conforme frases abaixo:

E1.202 - acho que o ser humano quando pensa no trabalho, acho que o lugar de trabalho a gente acaba sendo reconhecido pelo trabalho, e a falta dele... é uma identidade... e a falta dele pra essas pessoas, acho que tem prejuízo na auto-estima...

E6.62 - quando elas conseguem fazer uma peça e fica bonito eles também se valorizam por isso, se sentem úteis, e vê que conseguiu fazer uma coisa bonita, que vai vender, que vai retornar dinheiro pra oficina, então pra eles é importante também.

E7.14 - eles vão, passam a ver que a partir desse produto eles se colocam de uma outra forma, tanto por exemplo, desse grupo de trabalho, que é dentro da família, dentro da sociedade...

E4.31 - eles contratam a gente pela qualidade do nosso serviço, e o nosso valor também, o que a gente cobra é compatível com o mercado.

Esse reconhecimento pela capacidade produtiva e pela qualidade dos produtos é identificado como um aspecto transformador da percepção dos usuários sobre si mesmos, sobre sua auto-imagem, especialmente na relação com a família e com a sociedade, segundo fragmentos abaixo:

E7.17 - ...interessante que teve um encontro no Rio de Janeiro eles foram, foram no shopping, e no shopping viram os produtos feitos da oficina.

E7.18 - Então, você passa a ser reconhecido por aquilo que você produz, ou teu colega produz o que te representa...

E7.84 - Eles se vêm diferente...

E7.85 - A loja é muito bonita. Então assim, eles entram, o peito até ergue, assim sabe, se sente orgulhoso: Nossa esse aqui é o papel que eu fiz que está aqui?

E8.32 - Porque aqui eles produzem, são reconhecidos, têm uma bolsa legal que sustenta a família, eles ganharam muitas coisas, conquistaram muitas coisas aqui na oficina.

Contraditoriamente, embora as frases acima apontem para mudanças positivas dos usuários em direção à valorização da sua capacidade, 
prevalece a idéia de que somente o homem produtivo no trabalho pode ser digno, pode ter valor. Se o homem não produz segundo a lógica capitalista, ou seja, se ele não é considerado produtivo, perde sua humanidade. Tal visão corrobora com a ideologia burguesa na qual o trabalho produtivo humaniza e sem ele o sujeito perderia sua identidade de trabalhador, perdendo seu vinculo com os iguais e tornando-se um ser inútil à sociedade. Isso constitui um aspecto da alienação do trabalho, como vimos, o estranhamento.

O estranhamento ocorre quando 0 trabalhador não se reconhece no produto de seu trabalho, que se torna uma mercadoria estranha a ele. A mercadoria esconde o trabalho nela contido, ou seja, a ação transformadora do trabalhador, passando a ter uma existência própria, possuindo características humanas enquanto o trabalhador se desumaniza.

Alguns entrevistados aparentam acreditar que as mercadorias produzidas pelos usuários teriam o poder de inclusão social por meio da divulgação ou comercialização meio do mercado de consumo (circulação da mercadoria):

E7.16 (a oficina) - ela foi sendo, fazendo a reinserção social, através dos produtos que foram colocando, sendo colocados no mercado...

E8.39 - E eu acho que incluindo o produto no mercado, a gente está incluindo o usuário de uma certa forma na sociedade.

Outra significação do trabalho diz respeito à possibilidade de inclusão social a partir da recuperação da contratualidade, ou seja, da posse de recursos para trocas sociais, de acordo com as frases abaixo:

E1.200 - E aí isso assim que viabiliza a transformação da vida, pessoas que conseguem contribuir com a renda familiar e aí todas essas blá, blá, blás que a gente já sabe que são os benefícios da pessoa estar incluída numa situação de trabalho...

E4.53 - E lógico, que tem a parte da renda, que muitos não têm beneficio, não tem uma condição financeira nenhuma, adequada, e aí vivem mesmo com o dinheiro da bolsa oficina.

E5.24 - Tem a oportunidade de conseguir uma renda que os auxiliem em suas necessidades materiais. Eu acho que esses são os ganhos que eles têm.

E5.51 - é um trabalho que às vezes é bem exaustivo, mas que traz um bom retorno pra eles, financeiramente. 
O trabalho como necessidade para produção e reprodução da vida também aparece nos fragmentos quando referidos às falas dos usuários, demonstrando que para estes últimos o trabalho tem um sentido principal de geração de renda para aquisição de bens indispensáveis à melhoria da qualidade de vida:

E11.69 - E também acho que uma melhor condição de vida, que elas ganham com essa oportunidade.

E2.35 - eu acho que eles gostam muito disso, porque eles podem comprar as coisinhas deles e tudo, dependendo do valor...

E7.88 - são possibilidades de contar o que comprou com o dinheiro, o quê mudou na casa, o quê foi comprando.

E2.62 - Claro que o dinheiro é bom pra eles, porque eles compram aqui na cantina, eles compram roupa, todas essas coisas, saem, vão cortar cabelo.

E10.56 - eu acho que em relação à transformação da vida, eu acho que é uma melhora geral, eles conseguem pagar uma pensão de melhor qualidade, conseguem comprar algumas coisas pra eles mesmos, então, na parte financeira...

Esse sentido da utilização do trabalho não apenas como meio de sustento e auto-realização, mas que permite uma ampliação do poder contratual dos usuários, reitera sua importância como estratégia de reabilitação psicossocial para a cidadania. Como abordamos anteriormente é a possibilidade dessas trocas materiais no mercado que garante o direito à relação, é o negócio que precede o ócio (Saraceno, 2001). As frases abaixo se alinham com essa concepção da reabilitação psicossocial no eixo trabalho:

E8.33 (limites/dificuldades) - E a gente tem que garantir que vai ter uma bolsa sabe, não que a gente têm que garantir, mas a gente sabe que ele está contando com esse dinheiro.

E8.62 - e isso não é uma tarefa simples, porque às vezes você está com uma correria, com uma produção e o grupo pede o tempo todo que haja trabalho...

E7.95 (transformação na vida) - frases dos pacientes assim: agora posso comprar a televisão pro meu filho.

E11.60 - Parece que não, mas o valor de receber o dinheiro por algo que realizou, pra eles é importantíssimo.

E8.68 - às vezes uma bolsa, que a gente até considera baixa, que você pagou praquele oficineiro toda a família fica grata, como aquilo foi importante, há uma mudança sabe, na postura dele, no comportamento, é muito grato, gratificante. 
Considerando os discursos mencionados, a percepção dos usuários com relação ao trabalho nas oficinas difere da natureza terapêutica apontada pelos entrevistados. Os usuários não querem perder horas de trabalho para ir ao serviço de tratamento, pois isso implicaria na diminuição do valor da bolsa, uma vez que essas horas não são contabilizadas. Para eles a participação na oficina de trabalho permite uma modificação na sua condição econômica que se reflete nas suas relações sociais, especialmente com a família.

E3.1 (proposta da oficina) - são várias situações que a gente pode estar descrevendo, mas à medida que $X$, que já está com a gente há mais de 10 anos, chega pra gente agora, nestes últimos dois anos e diz assim: "Meu pai está desempregado, sou eu quem pago luz, água e sustento a família, não quero licença terapêutica, eu me sinto nervoso em casa, eu quero trabalho".

E10.28 - Às vezes eles preferem não ir no CAPS, ou não ir no centro de saúde, não fazer o tratamento, porque eles vão em horário comercial, no horário que eles estariam aqui na oficina, mas, como a gente conta horas, no final do mês a bolsa é calculada através das horas que eles trabalharam...

E10.29 - eles acham que não vale a pena ir no CAPS, perder uma tarde de trabalho, uma tarde de horas que seria calculada no final do mês, então tem que pegar no pé pra ir sim, porque senão tem gente que não vai não.

E2.59 - a gente nota também que pra eles, eles levam muito em consideração o valor da bolsa.

E2.60 - ganhar alguma coisa, importa muito, então às vezes eles não querem ir no tratamento pra ficar mais, pra bolsa aumentar mais, eles querem ser melhor pra avaliação ser melhor e pra eles ganharem mais.

Nessa perspectiva o trabalho pode ser compreendido como um recurso de reabilitação psicossocial que permite a inclusão social das pessoas com sofrimento mental, garantindo o respeito às suas diferenças e às suas necessidades e, portanto, dirigindo-se à conquista de sua cidadania:

E1.192 - Eu acho que possibilita a inclusão social, eu acho que oferece um lugar, e dá um espaço de pertencimento, então a gente vê casos que eu posso chamar de casos de sucesso, pessoas que vem pra oficina, que chegam numa situação de estar como morador de rua, com os vínculos familiares todos destruídos, e aí a pessoa consegue retomar, consegue trabalhar e até vai que consegue arrumar um emprego, e retoma a vida.

E1.199 - mas a maioria dos psicóticos que a gente tem no projeto hoje são pessoas que dificilmente conseguiriam um emprego no mercado formal de trabalho, então eu acho que tem que existir esse espaço pra acolher essas pessoas, que são pessoas que tem 
capacidade de produzir sim, só que precisa estar num espaço onde elas possam se expressar, que não tenha a competição que tem no mercado formal de trabalho, que está só pensando em quanto ele vai produzir, então a gente tem pessoas que conseguem fazer muita coisa, mas que tem o seu ritmo, e aí acho que espaços que respeitem isso tem que existir na saúde mental.

Os fragmentos de texto acima nos permitem ainda aproximar essa concepção de trabalho como alternativa de inclusão social das pessoas em situação de desvantagem social na perspectiva também do cooperativismo social e da economia solidária, que compartilha dos mesmos princípios éticos na elaboração de experiências alternativas de trabalho para a inclusão social das pessoas com dificuldades de inserção no mercado de trabalho formal.

\subsection{COOPERATIVISMO SOCIAL: TRABALHO E DESINSTITUCIONALIZAÇÃO}

A criação de cooperativas durante 0 processo de desinstitucionalização italiana permitiu o desenvolvimento da lógica do trabalho anti-institucional. Nesse processo, o estatuto jurídico do trabalhador louco evidenciou uma contradição e uma potencialidade, resultando na supressão da finalidade terapêutica dos estatutos da cooperativa e assim os pacientes puderam juridicamente constituir-se como sócios (Saraceno, 2001).

A cooperativa nesta lógica significava a possibilidade de ultrapassar os limites institucionais do processo de desinstitucionalização dirigindo-se ao mundo externo, ao mundo real, aos cenários de vida real, seguindo o princípio no qual desinstitucionalizar é reabilitar o contexto (Rotelli,1990 apud Saraceno, 2001).

A desinstitucionalização não deve, porém, e não pode ser praticada só no interior da instituição fechada (o manicômio): essa é prática de desarticulação e de análise dos mecanismos sociais, políticos, psicológicos que "ligam", ou melhor, "separam" a história do indivíduo dos âmbitos em que ela é obrigada a declinar em nome da manutenção desses mesmos âmbitos. Nesse sentido, a dupla conceitual desinstitucionalização-reabilitação que vale no hospital psiquiátrico vale em qualquer lugar, enquanto em toda a parte se re-propõe a necessidade de "desinstitucionalizar - reabilitar o contexto" (Saraceno, 2001, p. 132-3). 
Entretanto, esse movimento configurou num novo conflito polarizado entre 0 trabalho mais independente e 0 trabalho protegido, na qual este último embora configure maior potencial reabilitativo é caracterizado pela baixa rentabilidade econômica, correndo o risco ainda de manter a pobreza de recursos e a dependência institucional (Saraceno, 2001).

A passagem da situação mais protegida ao mercado livre do trabalho, apresenta alguns obstáculos aos modelos de reabilitação através do trabalho, que muitas vezes, reproduzem a ideologia do trabalho como terapia, norma moral, entretenimento e algumas vezes exploração, como por exemplo, o modelo anglo-saxão vocational rehabilitation, cuja finalidade relaciona-se à reinserção no mundo do trabalho, na perspectiva da adaptação ao mercado de trabalho (Saraceno, 2001). O fragmento abaixo aponta para um desses obstáculos: a dificuldade de interação social, entendida como fruto da vulnerabilidade individual:

E11.73 - Então muitas vezes a gente gostaria, a gente vê que tem algumas pessoas que poderiam arrumar emprego fora, jovens, pessoas muito novas, que estão com o quadro psíquico estabilizado e que poderiam, mas que não vão pro mercado lá fora por medo, não tem coragem de ir arrumar um emprego realmente por medo, de perder essa coisa mais protegida.

Outros modelos de reabilitação como o modelo francês de readaptacion, propõe a reinserção ao trabalho por meio de contratos de formação ou vagas de trabalho, financiados pela previdência social ou por contratadores de trabalho. De qualquer maneira, trata-se de um setting de trabalho mais tolerante, que exige menor habilidade e competência social (Saraceno, 2001) e, portanto, desqualifica e discrimina o trabalho dos vulneráveis, o que acaba por reforçar o estatuto da incapacidade e a necessidade de tutela dos doentes mentais. $O$ fragmento abaixo apresenta semelhanças com essa perspectiva, por não questionar o problema da relação entre trabalho e doença mental:

E11.76 - ...eu sou terapeuta ocupacional, minha tolerância vai ser muito maior, eu vou ouvir, eu vou entender quando está em crise, porque esse é o objetivo, também conseguir entender essas pessoas que tem um monte de problemas, que estão em crise, dentro desse espaço, o que não acontece lá no mercado lá fora, de jeito nenhum.

No decorrer do processo de invenção de estratégias desinstitucionalizantes pela Psiquiatria Democrática Italiana, a cooperativa 
se constituiu como o oposto da lógica exploradora do trabalho dependente e como uma forma concreta de solidariedade. Para Rotelli tratava-se de desinstitucionalizar o próprio trabalho, de reconstruir a exatidão da necessidade, separando o par trabalho/salário, ou seja, invertendo a lógica do trabalho explorado do paradigma psiquiátrico tradicional em direção à reabilitação psicossocial na qual o trabalho e o lucro são pontos de partida e não de chegada (Saraceno, 2001).

Com a evolução dessa estratégia da cooperativa, surgiu mais tarde, a idéia de "empresa social", que em linhas gerais, representava o desafio de criar uma empresa de reprodução social, a serviço da autonomia dos seus membros nas trocas sociais e nas relações institucionais, objetivando tanto a independência econômica quanto a independência subjetiva (Barros, 1994).

Nesse sentido, a empresa social buscava conciliar a ativação do potencial humano e de qualificação da imagem de quem adoece com o respeito àquilo que a pessoa pode fazer, sem, no entanto, prejudicar a qualidade dessa produção. Sua função também estava ligada à superação do assistencialismo, por meio da redução ou eliminação dos mecanismos de dependência institucional, em direção à reativação da riqueza das trocas sociais.

\begin{abstract}
Em outras palavras, trata-se de definir uma nova ética em cujo espaço seja possível reciclar tudo aquilo que seria descartável na lógica de uma ordem excludente. Dessa forma, realimentar a riqueza de uma organização complexa através de um conjunto de iniciativas políticas, administrativas, técnicas, culturais, operativas e afetivas que permitam recolocar os excluídos no circuito da vida e fazê-los sair da exclusão que foi por eles mesmos incorporados (Barros, 1994, p.103-104).
\end{abstract}

Nessa lógica, portanto, a cooperativa é compreendida como uma estratégia de formação e de trabalho por meio da constituição de um espaço de colaboração, de auto-organização e de promoção da autonomia, cuja finalidade última é a participação social. Entretanto, não se constitui uma tarefa fácil à transformação da visão assistencialista presente na relação reabilitação/inserção, como afirma o fragmento a seguir:

E1.26 - mais a questão de estar ali, fazer sozinho. Esse tem sido mais no individual. Não conseguimos até hoje nenhum grupo que fale: não, a gente vai ficar por conta disso e vamos tocar isso, esse contrato e não precisa do Cândido entendeu? Nem da associação. É sempre essa dependência. 
Segundo os entrevistados, os obstáculos dessa inversão da lógica do trabalho institucional são determinados tanto pela desabilidade individual dos usuários (falta de autonomia e incompreensão da proposta cooperativista), quanto pela necessidade de assistência, como observamos nos fragmentos de texto abaixo:

E1.191 - por mais que a gente converse, que tenha curso de cooperativa assim, é um trabalho que eu acho tem que ser... essa capacitação tem que ser contínua, você fala numa roda numa semana, passa duas semanas, volta de novo no mesmo assunto, parece que não tem fim assim: "Porque eu ganhei pouco, porque descontou o dia que eu fui no CAPS, porque não paga a hora de tratamento...". Sempre tem essas questões que voltam é...

E1.188 - Outra questão que acho que é mais interna que é a pouca autonomia dos oficineiros pra gestão assim, eu falei só da cultura, eu acho que além da cultura, tem a questão da baixa autonomia, a gente não recebe assim uma população que tem muito esse... é uma população que espera mais, que quer um trabalho, precisa de um trabalho, mas de um trabalho protegido... precisa de alguém que defina às vezes, e pedem muito.

Outras dificuldades da organização de cooperativas apontadas pelos entrevistados estão relacionadas às questões econômicas, como a falta de financiamento e de sustentabilidade, e às questões jurídicas, como a dificuldade de regulamentação legal das cooperativas sociais:

E1.186 - Aí pensando nas dificuldades e nos limites externos, eu acho que falta financiamento pra proposta de oficinas de trabalho e geração de renda...

E1.187 - falta uma legislação que dê conta de dar um respaldo pra essa prática, então assim hoje a gente não tem a lei, a organização jurídica de cooperativas sociais não está regulamentada, e acho que principalmente isso.

E11.79 - Olha sobre a cooperativa a gente já discutiu em outros momentos, já vimos uma vez a possibilidade de se tornar, mas ainda a gente viu que não era viável, por trâmites burocráticos e então a gente viu que não era viável, por enquanto.

A origem das cooperativas sociais, como vimos, remonta à experiência de reforma psiquiátrica italiana, que entre outras transformações, ocupou-se das questões jurídicas que envolviam 0 enfrentamento da reclusão social dos doentes mentais.

A lei italiana 180/78, conhecida por Lei da Reforma Psiquiátrica ou Lei Basaglia, foi resultado das ações e debates dos reformistas italianos e também da conjuntura política do período compreendido entre 1968 e 1978, quando os movimentos sociais (estudantis e operários) exigiam o 
alargamento da base democrática do Estado em termos legislativos. Tratase, portanto, de uma lei que foi determinada pela mobilização social e política dos atores envolvidos, oriunda da necessidade das transformações culturais em curso na realidade concreta, especialmente no campo da psiquiatria, e que objetivavam, sobretudo, eliminar as leis do passado à medida que estas eram impeditivas dessas mudanças (Amarante, 1992).

Mesmo considerando a importância da mudança jurídica, cabe ressaltar que trata-se de apenas uma etapa - necessária, mas não exclusiva -, desse processo de transformação cultural, organizativa e administrativa na gestão das estruturas (Rotelli apud Amarante, 1992).

Essa transformação operada no campo jurídico influenciou também o movimento da reforma psiquiátrica brasileira, que após anos de debates em torno do Projeto de Lei Paulo Delgado, conseguiu aprovar a Lei 10216/01, marco legal da reorientação da assistência em saúde mental no país, abrindo caminho para outras reformulações jurídicas que em linhas gerais, objetivavam a transformação da atenção à saúde mental, debatendo sobre a questão dos direitos de cidadania dessa população, especialmente com relação ao estatuto da incapacidade e periculosidade do doente mental, que historicamente foram associados à loucura pelo paradigma psiquiátrico manicomial (Barros, 1994).

A agressividade, violência e imprevisibilidade são atributos
historicamente associados à doença mental, mas que na prática da
reforma, desde a comunidade terapêutica aos serviços territoriais,
tem demonstrado que, na verdade, também a agressividade pode
ser dialeticamente trabalhada e transformada. Também as
infindáveis maneiras de expressão do sofrimento são reduzidas, por
definição, a uma única possibilidade de expressão: o
comportamento agressivo e violento. Ao mesmo tempo, não é dada
a violência manifesta de um determinado indivíduo a possibilidade
de defesa elucidando as razões do ato transgressor. (Barros, 1994,
p.138).

Dessa maneira, as intervenções e debates em torno da questão jurídica no contexto das mudanças culturais promovidas pela Psiquiatria Democrática Italiana, aprofundou-se ao longo desse processo, dando origem à lei das cooperativas sociais, que como já abordamos, tornou-se uma estratégia fundamental à desinstitucionalização e à inclusão social por meio do trabalho. 
No Brasil, a lei das cooperativas sociais, inspirada na lei italiana, surgiu da mesma necessidade de aprofundar o processo de reformulações da reforma psiquiátrica brasileira, em direção à construção de políticas públicas para a inclusão social pelo trabalho. Originalmente derivada do trabalho com pacientes psiquiátricos, essa lei estendeu seu alcance a outras pessoas em desvantagem social (Damiano, 2007).

A lei 9.867 , de 10/11/99, ou Lei de Cooperativas Sociais, fundamentase na promoção da pessoa em desvantagem social cuja inserção no mercado de trabalho foi limitada ou obstaculizada pelo modo de produção capitalista e pelo estigma social. Sua finalidade diz respeito ao:

\begin{abstract}
...interesse geral da comunidade em promover a pessoa humana e a integração social dos cidadãos, incluindo entre suas atividades a organização e gestão de serviços sócio-sanitários e educacionais e o desenvolvimento de atividades agrícolas, industriais, comerciais e de serviços (Damiano, 2007, p.204).
\end{abstract}

Baseada nas formulações do movimento cooperativista, as cooperativas sociais pretendem oferecer oportunidades de treinamento profissional e condições de trabalho adaptadas às dificuldades dessas pessoas, estimulando sua inserção no mundo produtivo, por meio de formas alternativas de produção baseadas na cooperação, e apoiadas em benefícios fiscais e administrativos.

Em síntese, o conceito de cooperativa é definido por:

uma sociedade de pessoas e não de capitais; apóia-se na ajuda mútua dos sócios; possuiu um objetivo comum e pré-determinado de afastar o intermediário e propiciar o crescimento econômico e a melhoria da condição social de seus membros, os quais possuem na união a razão de sua força; possui natureza civil e forma própria, regulada por lei especial; destinam-se a prestar serviços aos próprios cooperados (Mauad, 1999, p. 33).

A cooperativa social, embora suas particularidades, orienta-se pelos mesmos princípios das cooperativas, submetendo-se à normação da Lei das cooperativas tradicionais, mas com caráter beneficente, regida nos termos do artigo 44, II do Código Civil, sendo, portanto, pessoa jurídica de direito privado (Damiano, 2007).

Pela legislação, o enquadramento da situação de desvantagem social é condição para a associação da pessoa, sendo que a cessação dessa situação acarretará o seu desligamento da cooperativa social. É permitida a 
participação de voluntários na condição de associados, que podem prestar serviços à cooperativa, entretanto sem vínculo empregatício conforme art. 13 da Lei 9.608, de 18 de fevereiro de 1998.

No campo da saúde mental, essas diretrizes legais tornam-se obstáculos à constituição de cooperativas sociais no que se refere à participação de pessoas que não necessariamente se enquadram na definição de desvantagem, que deve ser atestada por laudo médico, como também à questão da capacidade civil de seus sócios, que em alguns casos são tutelados ou curatelados. Outra questão diz respeito à perda de benefícios previdenciários quando os usuários se tornam cooperados, passando à condição de segurado obrigatório da Previdência Social, o que inviabiliza a adesão dos usuários por receio de arriscar-se a perder tais benefícios (Alcântara, 2007).

Outro obstáculo diz respeito à tributação da cooperativa social que está baseada na mesma regra das cooperativas comuns, na qual $35 \%$ de sua arrecadação total destinam-se ao pagamento de impostos e composição de fundos (Alcântara, 2007). Nesse sentido, a autora defende a necessidade de revisão e reformulação da lei e das diretrizes do cooperativismo social, para diminuição e eliminação das barreiras que dificultam a transformação dos projetos de geração de renda, como o NOT, em cooperativas sociais.

$\mathrm{Na}$ análise dos dados, outras diferenças referidas entre a organização das oficinas de trabalho e a proposta das cooperativas sociais baseiam-se na capacidade de vagas limitadas no caso das cooperativas que não são sociais:

E1.51 - Que aí entra na questão da influência na geração de renda... as pessoas vão falar "é uma cooperativa", as cooperativas normais, que não são sociais, então as pessoas não pegam. Se eles precisam de dez pedreiros e tem dez pedreiros, não cabe mais nenhum. Se precisar de um eletricista e já tem aquele um, não admite mais nenhum naquela cooperativa, o nosso aqui, apesar de funcionar neste modo, a gente acaba incluindo mais pessoas do que seria aquela vaga... necessidade.

Outra questão considerada impeditiva à transformação da organização das oficinas de trabalho refere-se às relações interpessoais no interior do processo de trabalho. Na visão do entrevistado, é essencial a participação de profissionais da saúde na intermediação entre o grupo de 
usuários e entre esse grupo e o contexto social. Nesse sentido, enfatiza a necessidade do apoio de políticas públicas que possibilitem a assistência dessa população:

E1.52 - Eu acredito que, se a gente for pensar na cooperativa social, que eu acho que não funciona sem o respaldo do Estado, sem esta parceria aí que hoje a gente tem com a Saúde, ou com a assistência de qualquer outro, eu acho que sem isto fica difícil funcionar, a cooperativa normal para essa população, eu acho difícil.

E1.53 - Sem ter este subsídio, sem ter este vínculo, eu acho que dá um outro lugar para o projeto, para estar nesta Oficina, é o fato de ter um coordenador, de ter um monitor que acompanha as atividades, que lida com as relações, que faz essa intermediação aí das relações entre o grupo, da relação do grupo com o externo.

E1.54 - então eu acho que a gente tem muito vezes que ir ali no condomínio e falar para o Síndico... olha pega leve, quando você tiver alguma coisa para o usuário você fala para mim primeiro. Às vezes a coordenadora liga dizendo que eles reclamam que o Sindico é estúpido: a gente até acaba fazendo esta ponte. "Porque eu vou dar um murro na boca dele se ele vier falar comigo de novo" E a gente fala: não, não precisa fazer isso, quer reclamar, reclama com o monitor, reclama com a gente, fala isso, reclama com a gente, fala isso, se tiver nervoso tira as calças e pisa em cima, mas não vai falar bobagem porque o cara é meio estúpido... então essa ponte, eu acho que é fundamental...

Essas dificuldades da organização das cooperativas justificam a necessidade de acompanhamento de pessoas mais qualificadas, que, embora realizem uma intervenção no sentido da reabilitação psicossocial, acabam por reforçar a idéia da incapacidade das pessoas com sofrimento mental em comportar-se adequadamente nas interações sociais, e podem reproduzir a lógica assistencial e de dependência institucional, conforme textos abaixo:

E1.56 - . Eu vejo assim, nos grupos que a gente acompanha, acompanha assim entre aspas, observa o funcionamento que estão na Assistência Social aqui de Campinas, tem a Caritas que trabalha aqui em vários grupos, o pessoal da Assistência que tem os grupos de geração de trabalho e renda, são grupos que não tem esse profissional. O profissional da assistência às vezes vai uma vez por mês e no dia a dia não tem ninguém que trabalha as relações das pessoas, então as pessoas discutem um com outro e vão embora. Às vezes eles brigam vão embora e no outro dia a gente pergunta: "O que aconteceu ontem, vamos conversar, traz para o grupo, o que foi? Ah é que eu não gostei do que ele falou... Acaba dando um suporte para as pessoas e para o grupo e estas pessoas acabam ficando mais tempo e não abandonam.

E157 - Os problemas que eles têm lá, quando a gente discute, são os mesmos que a gente tem aqui. A diferença é que aqui a gente 
tem alguém que lida com isso e lá ninguém lida. Então assim, o presidente da cooperativa, são senhoras, donas de casa. Então não tem quem lide com isto. No dia a dia, com estas questões que sempre aparecem. Então são as mesmas.

E1.58- São as relações pessoais e que como não tem um chefe, também, estas relações de trabalho...

E1.59 (sobre chefe) - Ele não resolve, ele não tem a figura que é no imaginário e que aí a coisa anda, agora na cooperativa não tem, todo mundo é igual, e ninguém é igual, as diferenças aparecem e aí quem é que lida com isso?

A superação da lógica do trabalho protegido em relação à "lógica do assistido", na qual o usuário pouco participa ou pouco se apropria, constituise num desafio complexo para a promoção da autonomia e da autosuficiência, condições necessárias ao protagonismo dos usuários, que devem ser problematizadas pelos projetos de geração de renda e trabalho cujo horizonte estratégico seja a desinstitucionalização e a cidadania das pessoas com sofrimento mental (Nicácio, 2006).

Como abordamos anteriormente, as dificuldades e contradições que surgem nas relações sociais de produção, na maioria das vezes, são determinadas fundamentalmente pela organização do processo de trabalho, cujo modelo predominante tanto na ideologia dominante quanto na consciência social, inclusive dos usuários, familiares e profissionais, baseiase na forma capitalista onde 0 trabalho tornou-se essencialmente assalariado, parcelado e alienado.

Os entrevistados também fazem referência aos princípios do cooperativismo como a adesão livre e voluntária dos associados na organização da cooperativa de maneira coletiva e democrática, que ao invés do lucro, objetivo das empresas capitalistas, visa um interesse comum: a geração de renda para satisfação de suas necessidades (ITCP COPPE UFRJ, 2007). Esta diferença essencial está presente nas frases abaixo:

E7.10 - Ou seja, a partir da minha necessidade, consciência de convivência de uma geração de renda, eu perceber que eu preciso do outro pra poder atender aquilo que me traz até aqui.

E2.55 - na verdade, o intuito é trabalhar no sistema de cooperativa...

Outro princípio do cooperativismo, que orienta a organização dos empreendimentos solidários, relaciona-se à autogestão baseada na 
cooperação do trabalho e no respeito às diferenças como forma de superação do individualismo e da competição (Singer, 2002). Esses valores éticos foram apontados pelas frases abaixo como características do trabalho nas oficinas:

E4.61 - É um trabalho coletivo.

E4.66 - Mas aqui não, aqui são mais pessoas, a gente tem outro foco também, então a gente divide tudo, e é um trabalho grupal mesmo...

E4.67 - inclusive quando a gente percebe que não está acontecendo essa união é onde vai acontecendo os problemas, que aí a gente reforça de novo com todo mundo: gente, nós somos uma equipe, vamos ajudar.

E4.68 - Eles têm os problemas, lógico, mas eles trabalham em grupo.

E4.62 - Existem alguns que não gostam de trabalhar com o grupo, então eles ficam um pouco mais afastados, mas em si é um trabalho coletivo, um depende do outro: é um trabalho coletivo.

E5.28 - Então tem alguns que vão avançar mais, e têm outros que não, então, dentro do limite dele: o que é que ele pode fazer? $E$ dentro do que ele pode fazer ele é útil.

A solidariedade e a democracia são valores éticos que também orientam as ações de formação e educação dos sócios da cooperativa, conforme princípio do cooperativismo internacional. Essa condição de educação nas cooperativas sociais está presente nas caracterizações do processo de trabalho nas oficinas, de acordo com a frase abaixo:

E5.64 - isso pra mim não é mais uma coisa que me preocupa, é uma coisa que a oficina já vai no automático, então, antigamente eu via produto por produto e chamava e conversava e mostrava e identificava com eles o que estava ruim.

Além da educação, formação e informação dos associados, a participação econômica dos associados, princípio que define a contribuição igualitária dos associados para a formação do capital da cooperativa e do rateio das despesas gerais, configuram-se como características fundamentais das cooperativas, como também a garantia de autonomia e de independência em relação às outras cooperativas, instituições públicas e privadas, a cooperação entre as cooperativas e 0 interesse pela comunidade.

Os princípios do cooperativismo internacional, movimento que no Brasil é conhecido por Economia Solidária, buscam romper com as relações 
sociais de produção hegemônicas que se fundamentam na distinção entre duas classes sociais: os proprietários e os trabalhadores.

A empresa solidária nega a separação entre trabalho e posse dos meios de produção, que é reconhecidamente a base do capitalismo. A empresa capitalista pertence aos investidores, aos que forneceram o dinheiro para adquirir os meios de produção e é por isso que sua única finalidade é dar lucro a eles, o maior lucro possível em relação ao capital investido. O poder de mando, na empresa capitalista, está concentrado totalmente (ao menos em termos ideais) nas mãos dos capitalistas ou dos gerentes por eles contratados (Singer, 2002, p.83)

Retomando a formulação marxista, os trabalhadores vendem sua força de trabalho na forma de salário e o resultado de seu trabalho não lhes pertence, pois é de propriedade do patrão, que por sua vez, é proprietário dos meios de produção. Tanto esse modo de produção que transforma o trabalho em mercadoria e que permite a produção da mais valia, quanto o próprio processo de produção, que se caracteriza pela divisão social do trabalho, representam em síntese a alienação da classe trabalhadora e o domínio do capital sobre esta. Em um círculo vicioso, o trabalhador explorado e alienado, ao consumir sua força de trabalho e ao submeter-se às exigências das relações sociais de produção adoece física e mentalmente, necessitando em seguida reabilitar sua capacidade para retornar ao ciclo produtivo, como alternativa única de produção e reprodução da vida. Como já vimos, surge daí a necessidade de políticas assistenciais que se dirigem à reprodução social da força de trabalho para amenizar os efeitos da exploração capitalista e garantir a produtividade e continuidade do capital.

O movimento cooperativista surgiu nos primórdios do capitalismo industrial, como resposta à pobreza e ao desemprego decorrente do processo de industrialização, no início do século XIX. Baseados nos valores do socialismo, os trabalhadores das cooperativas objetivavam recuperar trabalho e autonomia econômica (Singer, 2002). Entretanto a suposta origem revolucionária do cooperativismo enfatizada por Singer, na verdade, caracterizava-se pela reação defensiva dos trabalhadores e também constituía a base do socialismo utópico, que para Marx e Engels, tratava-se de uma proposta reformista (Germer, 2006). 
Essa crítica deve-se ao fato de que Singer desconsidera o fato de que a luta contra o capitalismo na ocasião era concebida como uma luta restrita ao campo econômico, uma vez que os trabalhadores desconheciam a conexão entre a esfera econômica e a da ideologia, da política, da cultura e da estrutura social. Portanto, a origem das cooperativas não provém de uma motivação revolucionária e foram organizadas de maneiras distintas e com objetivos diferenciados (Germer, 2006).

Mesmo com as críticas quanto ao reformismo do cooperativismo, que para os autores marxistas, não representa um projeto de emancipação dos trabalhadores, uma vez que desconsidera a necessidade da luta de classes e superação do capitalismo, o próprio Marx assinala a importância da organização das fábricas-cooperativas por demonstrarem a possibilidade dos trabalhadores em assumir o controle da produção:

...as fábricas-cooperativas [...] demonstram que a produção em
grande escala e em consonância com o avanço da ciência moderna
pode ser realizada sem a existência de uma classe de patrões que
utiliza o trabalho de uma classe de mãos (hands) que, para produzir
frutos, os meios do trabalho não precisam ser monopolizados como
meio de dominação e de exploração contra o próprio operário; e
que [...] o trabalho assalariado é apenas uma forma social
transitória e inferior, destinada a desaparecer diante do trabalho
associado (Marx, 1975 apud Germer, 2006, p. 207).

De qualquer maneira, a evolução das sociedades, segundo o marxismo, se caracteriza pela história das transformações promovidas pelos seres humanos em diversos momentos históricos, que são resultantes dos movimentos dialéticos de superação das contradições inerentes à realidade, à totalidade. Nesse sentido, em que pese às críticas mencionadas, consideramos os processos de transformação como movimentos dialéticos resultantes das práticas e teorizações dos sujeitos envolvidos, participantes e protagonistas dessas mudanças.

Diante do exposto, consideramos que a associação de pessoas sob a forma de autogestão, ou seja, pela propriedade coletiva dos meios de produção e pelo controle democrático de todas as decisões do processo de trabalho nas cooperativas ou nos empreendimentos solidários, tornam essas alternativas de produção - não apenas de mercadorias ou de serviços, mas de promoção de autonomia e protagonismo social, baseadas em relações 
solidárias e cooperadas -, uma possível estratégia de reabilitação psicossocial e de inclusão social pelo trabalho, particularmente às pessoas com sofrimento mental. Evidentemente que para isso, se faz necessário aprofundar a reflexão e o debate sobre as potencialidades dessas experiências com relação ao respeito às diferenças e ao exercício do direito ao trabalho, como também sobre os obstáculos reais à constituição e à sustentação das cooperativas sociais e ainda, no âmbito estrutural, sobre os seus limites no que se refere à transformação mais profunda do trabalho no sentido da emancipação humana, que pressupõe a superação do modo de produção capitalista. 
CONSIDERAÇÕES FINAIS 


\section{CONSIDERAÇOES FINAIS}

...yo he preferido hablar de cosas imposibles, porque de lo posible se sabe demasiado.

Silvio Rodrigues.

Viver dialeticamente as contradições do real, como defendia Basaglia, configura-se num desafio de superação em vários sentidos: subjetivos, objetivos, relacionais, filosóficos, sociais, culturais e políticos. Se pensarmos a totalidade dialeticamente, constataremos a existência de contradições e conflitos em unidade ao mesmo tempo em conflito, corroborando com a primeira lei da dialética: a lei da unidade e luta dos contrários. Isso pressupõe uma primeira superação difícil de operar, a da lógica formal e positivista, que hegemonicamente vem moldando a consciência social.

A matriz positivista também modelou o saber psiquiátrico numa concepção mecanicista, copiada das ciências naturais, que se fundamenta no nexo causal entre os fenômenos, desconsiderando ou reduzindo as contradições presentes nos elementos biológicos, psicológicos e sociais da experiência humana (Basaglia, 1979). Essa maneira de conceber o mundo acarretou um reducionismo, uma objetivação do homem, que, neste caso particular, teve conseqüências drásticas às pessoas que apresentavam algum tipo de sofrimento mental. Ainda hoje permanece a concepção da loucura, originária do nascimento da psiquiatria, como sinônimo de periculosidade, de incapacidade, de invalidação, de custódia e de marginalização social.

O pensamento científico, como uma das expressões da superestrutura, reflete também a organização social de cada momento histórico, podendo carregar tanto uma tendência revolucionária de transformação social quanto uma tendência reacionária de manutenção do status quo. Portanto, a ciência não pode ser vista como algo natural nem neutro, mas determinado histórica e socialmente. Como fenômeno também está submetido às transformações históricas promovidas pelos seres humanos.

A história da psiquiatria é a história do conjunto de normas, que podem ser compreendidas como uma dialética entre indivíduo e grupo, 
subjetividade e coletividade, ou seja, entre homem e organização. A vida em sociedade se baseia na instituição de regras para a convivência social, cuja norma é o limite à individualidade dado pela coletividade, pela organização. Entretanto se esse indivíduo não participa da definição dessas normas, enquanto expressão de suas necessidades e dos outros, o limite será dado sempre pelo outro, no caso da organização capitalista, pela classe dominante, sendo reduzido à "condição de corpo dominado, corpo alienado e explorado por aquilo que o organiza" (Basaglia,1979, p. 278).

\begin{abstract}
A dialética entre indivíduo e organização deveria exprimir-se como dialética entre um corpo orgânico que seja apropriado pelo sujeito em sua organicidade junto ao grupo, donde, orgânico na construção das respostas às necessidades próprias e às do grupo, e um corpo social que seja a soma de sujeitos participantes da própria organização, e da organização das respostas às necessidades próprias e às do grupo. Corpo orgânico e corpo social seriam, nesse caso, expressão de uma subjetividade individual contida numa subjetividade coletiva (Basaglia, 1979, p. 278).
\end{abstract}

Entretanto, o que ocorre no sistema produtivo capitalista hegemônico é a redução desse corpo orgânico a corpo por meio da expropriação da força de trabalho humana e consequentemente sua exploração. O trabalhador não produz para si mesmo nem define as condições dessa produção, o produto de seu trabalho é apropriado por outro, e sua força de trabalho torna-se uma mercadoria cada vez mais desvalorizada pelo mercado, submetida às condições precárias de trabalho e de existência, transformando o trabalhador explorado num ser alienado de si e de sua espécie.

A alienação oculta o movimento dialético dos fenômenos, escondendo o fato de que as forças de mudanças vão acumulando lentamente na reprodução social, o que dificulta a consciência dos seres humanos sobre o movimento dialético da história e colabora na naturalização da realidade. Os momentos de transformação, embora comumente não percebidos como tal, são portanto resultantes de um processo de acúmulo operado pelos seres humanos em sua vida cotidiana, em especial em suas relações sociais de produção, em seu trabalho. (Gonçalves, 1992).

Dessa maneira, é imprescindível a transformação das consciências para a superação das contradições e para a transformação da realidade. Todavia, a transformação da consciência social como força propulsora de 
transformações sociais deve conter certa dose de protesto social, podendo expressar-se desde uma mera denúncia à implementação de práticas transformadoras da realidade (Fonseca, Egry, Bertolozzi, 2006).

No campo da saúde mental, as propostas reformadoras implantadas recentemente, cada qual com suas características próprias, partiram do questionamento e da crítica do modelo manicomial, propondo-se a conduzir mudanças na maneira da sociedade em lidar com a loucura. Como vimos estas propostas na realidade apresentam variações que vão desde a limitada humanização da assistência e reinserção adaptada às normas sociais até uma mudança mais profunda dessa relação histórica entre a loucura e a sociedade nos aspectos mais estruturais.

Com relação às mudanças no campo da Reforma Psiquiátrica Brasileira em direção ao processo de desinstitucionalização como emancipação, cabe aos usuários, familiares, trabalhadores em saúde mental, protagonistas dessas transformações, o estabelecimento de relações com os movimentos sociais que buscam recusar a opressão daqueles que não tem poderes para opor-se.

Os técnicos, por sua vez, devem usar o seu saber e poder, implícito ao papel de instrumentos de domínio, para inverter essa relação de controle, explicitando os processos de dominação para que a classe oprimida se aproprie desse conhecimento e possa recusar esse mecanismo. Não se trata de "limitar-se à eterna tarefa do intelectual burguês que ensina ao oprimido o caminho de sua libertação" (Basaglia, 1974, p.236), o que significa a perpetuação da distância e da dominação, mas de mostrar na prática o uso concreto da ciência burguesa sobre a dominação da classe subordinada, para que esta última tome consciência de todos os mecanismos de opressão, e possa recusá-los.

Trata-se portanto de refletir também sobre a função das instituições e dos processos de trabalho que definem o modelo assistencial. Nesse sentido, a construção de uma práxis transformadora no campo da saúde constitui-se no desafio inicial de discriminar as práticas de saúde verdadeiramente humanas das práticas de saúde alienada, considerando os fundamentos ontológicos da tríplice relação entre homem, natureza, e 
trabalho, para encontrar "os fundamentos ontológicos que permitam designar por saúde um certo conjunto de aspectos dessa tríplice relação em seu desdobramento histórico" (Gonçalves, 1992, p. 26).

O Modo Psicossocial preconiza uma definição de saúde numa perspectiva que a contextualize em relação a uma concepção de sociedade, entendida como conjunto de interesses contraditórios articulados, considerando a própria luta por saúde, tanto entendida como estado das condições de vida, quanto entendida como reivindicação de cuidados de saúde, como componente da própria definição de saúde. A especificidade da saúde mental, no Modo Psicossocial, define-se pela participação da dimensão sociocultural como intrínseca ao próprio processo de subjetivação (Costa-Rosa, Luzio, Yasui, 2001).

O processo de trabalho de atenção psicossocial, entretanto, não está livre de contradições e conflitos internos, uma vez que desafia os atores a construir consensos sobre as concepções teóricas e metodológicas e sobre as práticas que delas derivam. A problematização sobre a questão do poder e do controle também se torna tarefa fundamental no sentido de desconstruir valores éticos, morais e ideológicos que cercam a concepção da loucura na sociedade atual e inventar uma nova relação com esse fenômeno baseada na liberdade e na emancipação, considerando a ideologia dominante como determinante não apenas da ordem social, mas também das instituições, das concepções e valores daqueles que nela operam, os trabalhadores de saúde.

A superação dos mecanismos de controle dos loucos improdutivos pelas propostas de reabilitação psicossocial no eixo trabalho pressupõe também a conscientização acerca do papel das instituições psiquiátricas e também o trabalho na estrutura social atual.

Sendo o trabalho um componente vital para a transformação da consciência social no sentido da superação da alienação e da construção de um projeto emancipatório dos trabalhadores, trata-se de compreendê-lo como um espaço privilegiado em que se pode verificar na prática a ação desses mecanismos de opressão e controle social, e ao negá-los buscar 
também construir novas relações, seguindo os princípios cooperativistas de auto-gestão e tendo como horizonte a emancipação.

O trabalho, nessa perspectiva, torna-se um recurso estratégico de negação da alienação e subordinação, que pode constituir-se nessa práxis, visto que ao trabalhar os sujeitos não apenas modificam a natureza, mas modificam a si mesmos. Nesse processo estabelecem relações com outros sujeitos, identificando-se enquanto sujeito coletivo, cujas necessidades humanas (não mais individuais e alienadas) poderão ser alvo de um projeto coletivo de transformação em direção a emancipação humana.

Sendo assim, a modificação dos processos de trabalho de forma coerente com os resultados desejados, não apenas produtos ou serviços de qualidade, mas, sobretudo a possibilidade de uma práxis transformadora de todos os sujeitos envolvidos, técnicos, usuários, familiares, comunidade, desmistifica a questão da reabilitação psicossocial identificada com a desinstitucionalização como emancipação, que deixa de ser uma mera utopia, demonstrando sua efetividade e eficácia na transformação da vida dos sujeitos, em especial das pessoas com sofrimento mental, elo mais frágil dessa relação. Alguns dirão que isso é impossível, mas esse movimento dialético constitui a essência de todos os fenômenos e seu caminho não está definido, dependerá da ação concreta dos sujeitos que dele participam.

\footnotetext{
Trabalhar/cuidar é um processo dinâmico que inclui os sujeitos (profissionais e usuários) numa dialética. Emancipação é também um processo dialético: construímos a nós mesmos, nos emancipamos no trabalho: usuários e profissionais. O trabalho/ cuidado emancipatório, característico da atenção psicossocial, não se realiza pelo uso de uma determinada técnica, nem pela realização num determinado lugar, ou pela qualificação profissional de quem o realiza, ou pela especificidade de quem é atendido. Ele ocorre pela desalienação de todos os envolvidos (usuários e profissionais) (Oliveira, 2006, p. 701).
}

Como todo processo de mudança, caberá aos sujeitos a superação acumulativa das contradições até atingir o salto de qualidade, quando o ser passa a ser outro, quando surge a nova qualidade, que não aparece como num passe de mágica, mas resulta de um processo de sucessivas mudanças quantitativas que num determinado momento provocam uma mudança de qualidade, por meio de um movimento espiral que não nega a 
qualidade anterior, mas preserva seus resultados positivos no surgimento do novo (Egry, 2006).

Podemos considerar que o serviço NOT encontra-se no bojo desse movimento de superação, no contexto também das transformações operadas pela chamada Reforma Psiquiátrica Brasileira, perseguindo a negação da invalidação social histórica da loucura em direção ao reconhecimento social desta experiência tão humana quanto qualquer outra, e, portanto, digna de cuidado, proteção e eliminação das barreiras que a impedem de participar da sociedade de forma equânime, respeitando suas diferenças e suas potencialidades.

As contradições encontradas na análise desta experiência nos permitem inferir que a presença nos discursos de conceitos e intervenções conflitantes e por vezes antagônicas, com relação às propostas de reabilitação-desinstitucionalização dos usuários da saúde mental, correspondem às diferentes concepções do processo saúde-doença mental, que distinguem o modo asilar e modo psicossocial e que por sua vez determinam o modo de produzir saúde desses modelos assistenciais.

O problema da reabilitação do doente mental torna-se agora o problema do mascaramento das ideologias que de tempos em tempos o encobre e ao mesmo tempo é produzido à sua imagem e semelhança. A doença se transforma, de tempos em tempos, do que é originalmente - uma das contradições humanas contidas entre a vida e a morte - visto que vem definida, de tempos em tempos, para ser identificada, então, na instituição para ela designada (Basaglia, 1971).

Nesse sentido, uma contradição essencial que configura tanto 0 projeto institucional quanto o modo de estruturação e organização do processo de trabalho em saúde no serviço estudado diz respeito à diferenciação entre o campo da assistência e da produção, historicamente separados em dimensões distintas, mas articuladas pela dimensão estrutural, que co-existem nos serviços assistenciais que desenvolvem projetos ou oficinas de trabalho no campo da saúde mental.

A articulação entre esses dois campos num mesmo espaço institucional define todo o processo de trabalho em saúde bem como 0 processo de trabalho nas oficinas, que muitas vezes se mostram divergentes 
e conflitivos tanto para os trabalhadores da saúde quanto para os usuários trabalhadores, os oficineiros, em primeiro lugar sobre a sua identidade.

No caso dos coordenadores, essa dupla função ligada à assistência e ao controle da produção na oficina produz um conflito de prioridades, ora mais dirigida ao sujeito com sofrimento mental ora ao andamento da produção. Já para os sujeitos ao qual se destinam as intervenções, estes preferem ver-se como trabalhadores comuns ao invés de serem identificados como usuários de saúde mental, entretanto a relação estabelecida com a instituição e seus operadores não lhes permite superar essa contradição.

Essa contradição se apresenta também com relação ao estatuto do doente mental e a instituição que lhe foi outorgada, o hospital psiquiátrico, responsável por cuidá-lo e protegê-lo dos preconceitos sociais, ao mesmo tempo por afastá-los e reduzir o risco de sua inadequação social. Assim, a instituição psiquiátrica sempre esteve a cargo dessa função social em tratar, punir e curar pelo trabalho ao mesmo tempo em proteger a ordem social dos desvios e dos desviantes por meio do isolamento e do tratamento moral.

Logo, a utilização do trabalho nas propostas de reabilitação psicossocial pelas reformas psiquiátricas pressupõe uma reflexão critica dessa função social e do sentido do trabalho nos projetos de geração de renda e trabalho ou nos projetos de reinserção ao mundo da produção.

A discussão sobre o trabalho protegido ou assistido e o trabalho mais independente não é recente, como vimos nos estudos de Saraceno, mas todavia se faz presente nessas experiências, não apenas pelo receio dos oficineiros em perder essa proteção e dependência institucional como por parte dos coordenadores em confundir seu papel de cuidador da saúde, mas também pelas dificuldades que envolvem a produção das pessoas em desvantagem, especialmente com relação à sua habilidade ocupacional.

Como vimos, grande parte dos oficineiros não necessariamente chega ao serviço com algum conhecimento ou habilidade técnica, requerendo a princípio um treinamento em serviço, que no entanto, por vezes não é suficiente para superar algumas limitações decorrentes da baixa escolarização, das precárias condições de vida, e dos agravamentos decorrentes do sofrimento mental ou da medicação como prejuízos 
intelectuais e físicos. A questão da habilidade dos oficineiros torna-se um obstáculo, na maioria das vezes superável, contudo causando dificuldades ou prejuízos à produção das oficinas. Essa desabilidade individual também produz diferenças de valoração da capacidade produtiva entre os oficineiros, que se expressa nas diferentes funções e níveis de remuneração.

A superação dessas contradições exige um acompanhamento diário dos coordenadores e a utilização de um trabalhador intermediário (o monitor), responsável pelo treinamento dos oficineiros e supervisão do processo de produção, uma vez que os coordenadores muitas vezes não dispõem de conhecimentos ou habilidades técnicas necessárias à gestão do negócio e ao controle da produção.

Essa divisão de tarefas como abordamos configura uma organização trabalho baseada no parcelamento, correspondente com a divisão social do trabalho e com o trabalho alienado, que reproduz as relações e estruturas de poder hegemônicas da sociedade. Aqui novamente a questão do controle do processo de trabalho assemelha-se ao poder psiquiátrico, que consistia numa relação de subordinação e dominação do usuário pelo saber-poder dos operadores, contradizendo com a proposta de gestão democrática do processo de trabalho referida pelo serviço.

A auto-gestão caracteriza o processo de trabalho dos agentes coordenadores, mas não se amplia para o interior do processo de produção nas oficinas, uma vez que a existência de espaços de discussão coletiva é insuficiente à garantia de participação democrática nas decisões mais importantes da produção, especialmente com relação às questões financeiras como o valor da bolsa-oficina.

Como vimos a auto-gestão e a horizontalização das relações são condições necessárias ao processo de desinstitucionalização voltado à cidadania e a superação da alienação no trabalho, que no entanto, são obstaculizadas pelo trabalho assistido, protegido ou dependente, que contraditoriamente são mais favoráveis à reabilitação psicossocial dos sujeitos com sofrimento mental. Essa contradição foi identificada pelo próprio serviço que definiu dois tipos de público ao qual correspondem duas finalidades e dois processos de trabalho como abordamos anteriormente. 
A superação dessas contradições ou pelo menos a tentativa de superação de algumas delas, foi apontada pelos italianos pela proposição do dispositivo denominado empresa social que associaria a assistência com a produção, transformando o sentido do trabalho como também as relações e os contextos onde ele se realiza. Na empresa social, o sentido do trabalho pressupõe a superação do trabalho assalariado e do trabalho institucional, possibilitando o encontro de múltiplos intercâmbios, contaminações, sinergias entre os dois mundos da produção e da assistência, entre os que tem trabalho garantido e os vulneráveis, entre a acumulação de riquezas e a disseminação da misérias. (Leonardis, Amauri, Rotelli, 1995, p.9).

$\mathrm{Na}$ empresa social o sentido do trabalho e da produção dirigem-se não apenas a produção de mercadorias ou serviços compatíveis com o mercado de consumo, mas à reprodução social a partir das possibilidades de empreendimento, de trabalho e de intercâmbio social. A empresa social é, em efeito, uma estratégia produtiva, mas cujo lugar de eleição é o social, a reprodução, a assistência, a redistribuição (Leonardis, Amauri, Rotelli, 1995, p.13).

Opostamente à ergoterapia e ao tratamento moral, o sentido do trabalho na proposta da empresa social não consiste em trabalhar mas em empreender e nas condições econômicas, organizativas e relacionais para fazê-lo. O tratamento por sua vez não é pra normatizar mas para reconstituir a confiança e o respeito de si, a integridade e complexidade das pessoas, porque a liberdade, a autonomia e a responsabilidade somente se desenvolvem e se ampliam com o uso.

No entanto, a autonomia e a desalienação dos usuários só pode estar associada à autonomia e à desalienação dos trabalhadores. A autonomia dos trabalhadores e dos usuários por sua vez associa-se à superação dos modos de existência e funcionamento das instituições que são características do Modo Asilar. A organização da instituição de saúde mental como dispositivo segundo a mesma lógica das instituições típicas do modo capitalista de produção produz uma série de efeitos refletidos na sua 'produção', que são desastrosos e às vezes letais. 
momento histórico da intermediação da instituição nas práticas de Atenção) da relação dos trabalhadores de saúde mental e dos usuários. Mas o melhor começo será, sem dúvida, reconhecer essa intermediação e desvendar-lhe a anatomia para descobrir as operações que são necessárias para fazer esse intermediário trabalhar a favor da ética que preconizamos em nossas práticas de atenção (Costa-Rosa, Luzio, Yasui, 2001, p.21/2).

Essa necessidade de reflexão e problematização dos saberes e práticas reabilitadoras pelo trabalho foi apontada pelos entrevistados, demonstrando uma disponibilidade e interesse nesse processo de negação/desconstrução/invenção de novas práticas que permitam o respeito à singularidade bem como à coletividade dos oficineiros na busca pela satisfação de suas necessidades.

Nesse processo de transformação, avaliamos a necessidade de superação dessas contradições e de alguns obstáculos das propostas de reabilitação psicossocial pelo trabalho que se dirigem à cidadania e que se identificam com o processo de desinstitucionalização como emancipação. Dentre eles, destacamos:

- a dificuldade de acesso ao serviço, limitada tanto pelo número de vagas, pelos critérios de inserção, quanto pela localização afastada do centro da cidade;

- a necessidade de envolvimento maior dos familiares, espaço microsocial fundamental à mudança na qualidade das relações;

- a necessidade de participação comunitária não apenas para as trocas materiais, mas para as trocas sociais fundamentais à contratualidade;

- a necessidade de criação de outros espaços de capacitação e trabalho situados nos cenários de vida real, onde se consome, se produz, se reproduzem as relações, onde se vive.

- a necessidade de participação efetiva dos oficineiros no controle e na definição de todas as etapas do processo de trabalho nas oficinas, condição fundamental à superação da dependência institucional, da alienação e da utilização do trabalho como mecanismo de adaptabilidade e controle social em direção à promoção da autonomia e da participação social. 
- a necessidade de capacitação técnica e formação política de todos os sujeitos envolvidos no sentido da conscientização dos elementos que determinam a invalidação da loucura e das formas de superação dessa condição, que pressupõe o esclarecimento dos mecanismos de controle institucional e social e a discussão coletiva das formas de enfrentamento dessa situação, que em última instância passa pela transformação social.

- a experimentação de outras formas de remuneração e de organização da produção como proposta pelo cooperativismo social, onde os oficineiros possam configurar-se como sócios, incluindo ainda pessoas comuns, que também sofrem com a redução dos postos de trabalho, promovendo, por conseguinte, sua participação social na condição de cidadãos, cientes dos seus direitos e deveres, e protagonistas de sua própria história, enquanto sujeito coletivo, deixando claro que se trata ainda de uma etapa desse processo de acumulação quantitativa.

- a superação da lógica normatizante, disciplinadora, exploradora, parcelada e alienante da utilização do trabalho nas propostas reabilitadoras, em forma e conteúdo, pela utilização do trabalho como práxis coletiva que possa caminhar em direção a uma nova relação da sociedade com a loucura, pautada no respeito às diferenças, na validação social e na desinstitucionalização como emancipação.

Evidentemente que todas as questões apontadas acima não se constituem em tarefas fáceis e exclusivas dos coordenadores ou administradores do NOT, trata-se de uma reflexão derivada da análise desta realidade particular que pretende alcançar a temática da reabilitação psicossocial voltada à desinstitucionalização como emancipação cuja finalidade última é a inclusão social pelo trabalho.

Logo, cabe aos sujeitos envolvidos e interessados nessa temática a reflexão e elaboração de estratégias que possibilitem a eliminação dos obstáculos e a superação das contradições que caracterizam as propostas de reabilitação psicossocial ou de inclusão social pelo trabalho no campo da 
saúde mental. Tanto os trabalhadores da saúde quanto os usuários e familiares devem protagonizar debates e intervenções transformadoras, envolvendo também outros autores não necessariamente ligados à saúde mental, transpondo os limites dessa discussão ainda circunscrita ao campo da saúde.

São os trabalhadores que colocam em práticas as mudanças propostas pelas políticas sociais, contudo, somente a participação efetiva dos usuários poderá transformar a relação de tutela e dominação que caracterizou a história da psiquiatria e de seus aparatos de controle em direção à sua libertação e emancipação humana. Nesse sentido, podemos caminhar na direção de uma práxis na qual a emancipação passe a constituir de fato uma restituição do mundo humano e das relações humanas ao próprio homem. 


\section{REFERÊNCIAS}




\section{REFERÊNCIAS}

Alcântara LC. Economia solidária e oficinas de trabalho na saúde mental.In: Merhy EE, Amaral H, organizadores. A reforma psiquiátrica no cotidiano II. São Paulo: Aderaldo \& Rothschild; 2007. p. 151-181.

Amarante PDC. A lei 180 e a reforma psiquiátrica italiana - história e análise atual. Entrevista com Franco Rotelli, Trieste, 1992 In: Bezerra Junior B, Amarante $\mathrm{P}$, organizadores. Psiquiatria sem hospício: contribuições ao estudo da reforma psiquiátrica. Rio de Janeiro: Relume-Dumará; 1992. p. 9198.

Amarante PDC, coordenador. Loucos pela vida: a trajetória da reforma psiquiátrica no Brasil. Rio de Janeiro: Fiocruz; 1995.

Amarante PDC. O homem e a serpente: outras histórias para a loucura e a psiquiatria. Rio de Janeiro: Fiocruz; 1996.

Amarante PDC. Saúde mental e atenção psicossocial. Rio de Janeiro: Fiocruz, 2007.

Antunes R. Os sentidos do trabalho: ensaio sobre a afirmação e a negação do trabalho. $1^{\underline{a}}$ ed. São Paulo: Boitempo; 1999.

Aranha e Silva AL; Fonseca RMGS. Processo de trabalho em saúde mental e o campo psicossocial. Rev. Lat-Am Enferm. 2005;13(3):441-9.

Armazém das Oficinas [on line], disponível em http://www.armazemoficinas.com.br/ , acessado em 15/02/2009.

Barros DD. Habilitar - reabilitar...: o rei está nu? Rev Ter Ocup. 1991;2(2/3):100-4.

Barros DD. Jardins de Abel: desconstrução do manicômio de Trieste. São Paulo: EDUSP; 1994.

Barros S; Aranha e Silva AL; Oliveira MAF. Inclusão social de pessoas com transtornos mentais severos e persistentes: um desafio pedagógico. Rio de Janeiro: IPUB. 2000;19:171-81. 
Barros S; Egry EY. O louco, a loucura e a alienação institucional: o ensino da enfermagem psiquiátrica sub judice. Taubaté: Cabral; 2001.

Basaglia F. A psiquiatria alternativa: contra o pessimismo da razão, o otimismo da prática. Conferências no Brasil. São Paulo: Brasil Debates; 1979.

Basaglia, F. Escritos selecionados em saúde mental e reforma psiquiátrica. Rio de Janeiro: Garamount, 2005. A utopia da realidade. p. 225-36.

Basaglia, F. Escritos selecionados em saúde mental e reforma psiquiátrica. Rio de Janeiro: Garamount, 2005. O circuito do controle: do manicômio à descentralização psiquiátrica. p.237-57.

Basaglia F. Scritti (1968-1980): dall'apertura del manicomio alla nuova legge sull'assistenza psichiatrica. Torino: Guilio Eunaudi;1982. Riabilitazione e controllo sociale. P. 199-208. Tradução livre por Ana Luisa Aranha e Silva. Texto apresentado ao Comitê Internacional Contra o Sofrimento Mental, Helsinki; 1971.

Benetton MJ. Terapia ocupacional e reabilitação psicossocial: Uma relação possível? In: Pitta A. reabilitação psicossocial no Brasil. São Paulo: Hucitec, 2001, p. 143-49.

Bezerra BJ. Cidadania e loucura: um paradoxo? In: Bezerra BJ. Amarante P. organizadores. Psiquiatria sem hospício: contribuições ao estudo da reforma psiquiátrica. Rio de Janeiro: Relume-Dumará; 1994. p. 113-126.

Birman J. A cidadania tresloucada: notas introdutórias sobre a cidadania dos doentes mentais. In: Bezerra BJ. Amarante P. Organizadores. Psiquiatria sem hospício: contribuições ao estudo da reforma psiquiátrica. Rio de janeiro: Relumé-Dumará; 1992. p. 71-90.

Brasil. Ministério da Saúde. Secretaria de Atenção à Saúde. SVS/CNDST/AIDS. A Política do Ministério da Saúde para Atenção Integral a Usuários de Álcool e Outras Drogas. Ministério da Saúde. $2^{\underline{a}}$ ed. rev. ampl. Brasília: Ministério da Saúde, 2004.

Brasil. Ministério da Saúde. Secretaria de Atenção à Saúde. Coordenação Geral de Saúde Mental. Reforma psiquiátrica e políticas de saúde mental no 
Brasil. Documento apresentado à Conferência Regional de Reforma dos Serviços de Saúde Mental: 15 anos depois de Caracas. OPAS. Brasília; 2005.

Brasil. Ministério da Saúde. Secretaria de Atenção à Saúde. Departamento de Ações Programáticas Estratégicas. Saúde Mental e Economia Solidária: Inclusão Social pelo Trabalho. Brasília: Ministério da Saúde; 2006.

Brasil. Ministério da Saúde. Secretaria de Atenção à Saúde. Relatório de Gestão 2003-2006: saúde mental no SUS: acesso ao tratamento e mudança do modelo de atenção. Brasília: Ministério da Saúde; 2007.

Campos CJG. Método de análise de conteúdo: ferramenta para a análise de dados qualitativos no campo da saúde Rev Bras Enferm, Brasília (DF) 2004; 57(5):611-4.

Campos FCB. O modelo da reforma psiquiátrica brasileira e as modelagens de São Paulo, Campinas e Santos. [tese] Campinas: Unicamp; 2000.

Canguilhem, G. O normal e o patológico. $2^{\mathrm{a}}$ ed. Rio de Janeiro: Forense; 1982.

Canoni, S. Michel Foucault. E a persistência do poder psiquiátrico. Ciên Saúde Col; 2009;14(1):95-103.

Cappelle MCA; Melo MCOL; Gonçalves CA. Análise de conteúdo e análise de discurso nas ciências sociais. Rev Adm UPLA; 2003;5(1).

Caraciolo JMM, Shimma E, organizadoras. Adesão da teoria a prática: experiências bem sucedidas no Estado de São Paulo. São Paulo: Centro de Referência e Treinamento DST/Aids; 2007.

Castel R. A ordem psiquiátrica: a idade de ouro do alienismo. São Paulo: Graal; 1978.

Castel R. As metamorfoses da questão social: uma crônica do salário. Petrópolis: Vozes; 1998. 
Cayres CO; Domitti AC; Carnevalli MEC; Bianchini V. O desafio da reabilitação profissional. In: Harari A; Valentini W. Organizadoras. A reforma psiquiátrica no cotidiano. São Paulo: Hucitec, 2001. p. 105-112.

Chauí M. Convite à filosofia. São Paulo: Ática; 1995.

Constituição da República Federativa do Brasil. 42ed. atual. ampl; 2009.

Costa-Rosa A, Luzio CA, Yasui S. As conferências nacionais de saúde mental e as premissas do modo psicossocial. Saúde em Debate. Rio de Janeiro; $2001 ; 25(58): 12-25$

Leonardis O; Mauri D; Rotelli F. La empresa social. Buenos Aires: Edicones Nueva Visión; 1995.

Delgado PGG. As razões da tutela: psiquiatria, justiça e cidadania do louco no Brasil. Rio de Janeiro: Te Corá; 1992.

Delgado J. A loucura na sala de jantar. Santos, s/e; 1991. Reflexões na cidade sem manicômios. p.11-26.

Dejours C. A banalização da injustiça social. Rio de Janeiro: FGV; 1999.

Dicionário Jurídico [on line], disponível em http://www.direitonet.com.br, acessado em 29/11/2007.

Domitti ACP, Carnevalli MEC, Bianchini VAS. Núcleo de oficinas de trabalho. Campinas: Serviço de Saúde Dr. Cândido Ferreira; 2001. [on line] disponível em http://www.candido.org.br, acessado em 09/09/2007.

Engels F. Carta a Bloch de 21/22 de setembro de 1890. In: Engels, F; Marx, K. Obras escolhidas, v.3. São Paulo: Alfa-Ômega, s/d. p. 284-286.

Engels F. Dialéctica da natureza. Lisboa: Presença, s/d. p. 49-56. 
Engels $F$. Sobre o papel do trabalho na transformação do macaco em homem. [1876]. In: Engels, F; Marx K. Obras escolhidas, v.2. São Paulo: Alfa-Ômega, s/d. p. 267-280.

Egry EY. Compreendendo a dialética na aproximação com o fenômeno saúde doença. In: Egry EY; Cubas MR. O trabalho da enfermagem em Saúde Coletiva no cenário CIPESC. Curitiba: Associação Brasileira de Enfermagem; 2006.

Fiorin JL. Linguagem e ideologia. São Paulo: Ática; 1990.

Fiorin JL. Elementos da análise de discurso. São Paulo: Contexto; 2006.

Fiorin JL. Para entender o texto: leitura e redação. São Paulo: Ática;1992.

Foucault M. Ditos e escritos I. Problematização do sujeito: Psicologia, Psiquiatria e Psicanálise. Rio de Janeiro: Forense; 1999.

Foucault M. História da loucura na idade clássica. São Paulo: Perspectiva; 1978.

Fromm E. Conceito marxista do homem. Rio de Janeiro: Zahar; 1983.

Germer C. A "economia solidária": uma crítica marxista. Outubro. 2006;14:194-214.

Goffman E. Prisões, manicômios e conventos. São Paulo: Perspectiva; 1974.

Goldberg IJ. Reabilitação como processo - O Centro de Atenção Psicossocial. In: Pitta A. Reabilitação psicossocial no Brasil. $2^{a}$ ed. São Paulo, Hucitec; 2001; p. 33-47.

Gonçalves RBM. Práticas de saúde: processos de trabalho e necessidades. Faculdade de Medicina. Universidade de São Paulo; 1992/Mimeografado. 
Guanais MAB. Do significado aos sentidos do trabalho: dizeres de sujeitos em oficinas protegidas.[tese] Campinas: Pontifícia Universidade Católica; Instituto de Psicologia e Fonoaudiologia; 2000.

Guerra AMC. Oficinas em saúde mental: percurso de uma história, fundamentos de uma prática. In: Costa CM; Figueiredo AC; Oficinas terapêuticas em saúde mental: sujeito, produção e cidadania. Rio de Janeiro: Contra Capa; 2004. p. 23-58.

lasi ML. As metamorfoses da consciência de classe. São Paulo: Expressão Popular; 2006.

lasi ML. Ensaios sobre consciência e emancipação. São Paulo: Expressão Popular; 2007.

Incubadora Tecnológica de Cooperativas Populares. COPPE. Rio de Janeiro, Universidade Federal do Rio de Janeiro; 2007.

Kojève A. Introdução à leitura de Hegel. Rio de Janeiro: Contraponto: EDUERJ; 2002.

Leal EM. Trabalho e reabilitação psiquiátrica fora do contexto hospitalar. In: Costa, CM.; Figueiredo, A C; Oficinas terapêuticas em saúde mental: sujeito, produção e cidadania. Rio de Janeiro: Contra Capa 2004. p. 11-22.

Leão A. As práticas de inclusão social: o desafio para os serviços de saúde mental. [dissertação]. São Paulo: Escola de Enfermagem da USP; 2006.

Leonardis O, Mauri D, Rotelli F. La empresa social. Buenos Aires: Nueva Vision; 1995.

Lefebvre H. Lógica formal/lógica dialética. Rio de Janeiro: Civilização Brasileira;1979.

Lessa S. História e ontologia: a questão do trabalho. Crítica Marxista. 2005;20: 70-89. 
Lima JC. O trabalho autogestionário em cooperativas de produção: o paradigma revisitado. Rev Bras de Ciências Sociais. 2004;19(56):45-74.

Machado R. Danação da norma: a medicina social e constituição da psiquiatria no Brasil. Rio de Janeiro: Graal; 1978.

Mângia EF. Alienação e trabalho. Rev. Ter. Ocup. 2003;14(1):34-42.

Mângia EF. Psiquiatria e tratamento moral: o trabalho como ilusão de liberdade. Rev. Ter. Ocup. 1997;8(2/3):91-7.

Marx K. Manuscritos econômico-filosóficos. Lisboa: Edições 70; 1975. O trabalho alienado. p. 157-172.

Marx K. O capital: crítica da economia política. Livro Primeiro. O processo de produção do capital. Vol I. Rio de Janeiro: Civilização Brasileira S.A; s/d.

Marx K. O capital: crítica da economia política. Livro Primeiro. O processo de produção do capital. Vol II. Rio de Janeiro: Civilização Brasileira S.A.; 1890.

Mauad MJL. Cooperativas de trabalho: sua relação com o direito do trabalho. São Paulo: LTr; 1999.

Minayo MC de S. O desafio do conhecimento: pesquisa qualitativa em saúde. 9ª ed. São Paulo: Hucitec;2006.

Nascimento EF; Pinho PH; Taleikis PU. Projetos de inserção laborativa em saúde mental: uma análise da produção científica de 1995 a 2006. [monografia]. São Paulo. Escola de Enfermagem da USP; 2006.

Nicácio MF. Organizadora. Desinstitucionalização. São Paulo: Hucitec;1990.

Nicácio MF. Utopia da realidade: contribuições da desinstitucionalização para a invenção de serviços de saúde mental [tese]. Campinas: UNICAMP; 2003. 
Nicácio MF. In: Brasil. Ministério da Saúde. Secretaria de Atenção à Saúde. Departamento de Ações Programáticas Estratégicas. Saúde Mental e Economia Solidária: inclusão social pelo trabalho. Brasília: Ministério da Saúde; 2005.

Onocko R; Amaral M. Cândido Ferreira: experimentando uma mudança institucional. In: Merhy EE; Onocko R. Organizadores. Agir em saúde: um desafio para o público. $2^{\circ}$ ed. São Paulo: Hucitec; 2002. p. 353-372.

Oliveira AGB; Alessi NP. Cidadania: instrumento e finalidade do processo de trabalho na reforma psiquiátrica. Ciênc Saúde Col. 2005;10(1):191-203.

Oliveira AGB. Reflexão sobre trabalho e cuidado em atenção psicossocial. Esc Anna Nery R Enferm 2007;10(4):694 - 702.

Organista JHC. O debate sobre a centralidade do trabalho. São Paulo: Expressão Popular; 2006.

Pires D. A estrutura objetiva do trabalho em saúde. In: Leopardi MT. Organizadora. Processo de trabalho em saúde: organização e subjetividade. Florianópolis: Programa de Pós Graduação em Enfermagem/UFSC; PapaLivros; 1999. p. 25-48.

Pires D. Reestruturação produtiva e trabalho em saúde no Brasil. $2^{\circ}$ ed. São Paulo: Confederação Nacional dos Trabalhadores em Seguridade Social CUT; Annablume; 2008.

Pitta A. Reabilitação psicossocial no Brasil. São Paulo: Hucitec; 2001. O que é reabilitação psicossocial no Brasil, hoje? p. 19-26.

Prefeitura Municipal de Campinas [on line], disponível em http://www.campinas.sp.gov.br, acessado em 09/09/2007.

Rotelli F. Empresa Social: construindo sujeitos e direitos. In: Amarante P. Organizador. Ensaios: subjetividade, saúde mental, sociedade. Rio de Janeiro: Fiocruz; 2000.

Rotelli F. Superando o manicômio: o circuito psiquiátrico de Trieste. In: Amarante PDC. Organizador. Psiquiatria social e reforma psiquiátrica. Rio de Janeiro: FIOCRUZ; 1994. p. 149-170. 
Rotelli F; Leonardis O; Mauri D. Desinstitucionalização uma outra via. A reforma psiquiátrica italiana contexto da Europa Ocidental e dos "Países Avançados". In Nicácio MF. Organizadora. Desinstitucionalização. São Paulo: Hucitec;1990. p. 17-60.

Rezende H. Política de saúde mental no Brasil: uma visão histórica. In: Tundis AS; Costa NR. Cidadania e loucura: políticas de saúde mental no Brasil. Petrópolis: Vozes; 1987, p. 15-74.

Sánchez Vasquez A. Filosofia da práxis. Buenos Aires: CLACSO; São Paulo: Expressão Popular; 2007.

Santos BS. A reinvenção solidária e participativa do Estado. Seminário Internacional Sociedade e a Reforma do Estado. Coimbra: Faculdade de Economia da Universidade de Coimbra - Centro de Estudos Sociais; s/d.

Saramago J. A caverna. São Paulo: Companhia das Letras; 2000.

Saraceno B. Libertando identidades: da reabilitação psicossocial à cidadania possível. Belo Horizonte/ Rio de Janeiro: Te Cora; 2001.

Silva ALA. O projeto copiadora do CAPS: do trabalho de reproduzir coisas à produção de vida [dissertação]. São Paulo (SP); Escola de Enfermagem da USP; 1997.

Sistema Único de Saúde. Conselho Nacional de Saúde. Comissão Organizadora da III CSM. Relatório Final da III Conferência Nacional de Saúde Mental. Brasília: Ministério da Saúde; 2002.

Souza PCZ. O trabalho como possível: o caso das pessoas com "transtornos mentais graves" [doutorado] Rio de Janeiro: UERG; 2006.

Secretaria Municipal de Saúde [on line], disponível em http://antigo.campinas.sp.gov.br, acessado em 29/01/09.

Serviço de Saúde Dr. Cândido Ferreira [on line], disponível em http://www.candido.org.br, acessado em 09/09/2007. 
Silva Filho JF. A medicina, a psiquiatria e a doença mental. In: Tundis AS; Costa NR. Cidadania e loucura: políticas de saúde mental no Brasil.

Petrópolis: Vozes; 1987, p.75-102.

Silva Filho JFC; Amim V. Reabilitação: da ergonomia à clinica. In:

Organização do Trabalho e Saúde Mental. Rio de Janeiro:IPUB, 2000: ํo 2 (4ํe ed):115-128.

Strutti C. La empresa social. Bogotá: Programa PTREV; 1997.

Tikanori R. Contratualidade e reabilitação psicossocial. In: Pitta A.

Reabilitação psicossocial no Brasil. $2^{\underline{a}}$ ed. São Paulo, Hucitec; 2001, p. 5559.

UNISOL Brasil Central de Cooperativas e Empreendimentos Solidários [on line], disponível em http://www.unisolbrasil.org.br, acessado em 29/11/2007.

Vasconcelos, EM. O poder que brota da dor e da opressão: empowerment, sua história, teorias e estratégias. São Paulo: Paulus; 2003.

Vaz MRC. O trabalho em saúde: expressão viva da vida social. In: Leopardi MT. Organizadora. Processo de trabalho em saúde: organização e subjetividade. Florianópolis: Programa de Pós Graduação em Enfermagem/UFSC: Papa-Livros; 1999. p. 57-70.

Zauhy C; Mariotti H. Acolhimento: o pensar, o fazer, o viver. Secretaria Municipal da Saúde. São Paulo; 2002. 
ANEXOS E APÊNDICES 


\section{ANEXOS E APÊNDICES}

\section{Anexo 1: Parecer do Comitê de Ética em Pesquisa da Escola de Enfermagem da USP (CEP-EEUSP)}

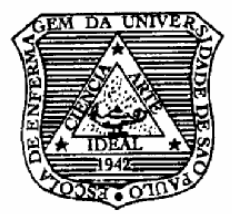

UNIVERSIDADE DE SÃO PAULO

ESCOLA DE ENFERMAGEM

Av. Dr. Enéas de Carvalho Aguiar, 419 - CEP 05403-000

? Fone: 3061-7548 - Fax: 3061-7548

C.P. 41633 - CEP 05422-970 - e-mail: edipesq@usp.br

São Paulo, 20 de março de 2008.

II. ${ }^{\mathrm{ma}} \mathrm{Sr}^{\mathrm{a}}$

Paula Urzúa Taleikis

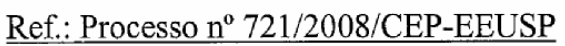

Prezada Senhora:

Em atenção à solicitação referente à análise do projeto "Saúde Mental e Trabalho: a cooperativa social como estratégia de Reabilitação Psicossocial”, informamos que o mesmo foi considerado aprovado pelo Comitê de Ética em Pesquisa da Escola de Enfermagem da Universidade de São Paulo (CEP/EEUSP).

- Analisado sob o aspecto ético-legal, atende às exigências da Resolução n 196/96 do Conselho Nacional de Saúde.

Esclarecemos que após o término da pesquisa, os resultados obtidos deverão ser encaminhados ao CEP/EEUSP, para serem anexados ao processo.

Atenciosamente,

navie fel firnander

Prof. ${ }^{\text {a }}$ Dr. ${ }^{a}$ Maria de Fátima Prado Fernandes Coordenadora do Comitê de Ética em Pesquisa da Escola de Enfermagem da Universidade de São Paulo 
Anexo 2: Parecer da Comissão de Ética do Serviço de Saúde Dr. Cândido Ferreira

SERVIÇO DE SAÚDE DR. CÂNDIDO FERREIRA

COMISSÃO DE ÉTICA MÉDICA

PARECER N 10/2008

Acerca do pedido de parecer desta Comissão para REALIZAÇÃO DE UM PROJETO DE PESQUISA.

Título: SAÚDE MENTAL E TRABALHO: A cooperativa social como estratégia de Reabilitação Psicossocial.

Solicitante: Paula Urzúa Taleikis

Orientação: PROFa.DRa. Sônia Barros

Projeto de pesquisa apresentado ao Exame de Qualificação do Programa de Pós-graduação em Enfermagem - mestrado pela USP - Universidade de São Paulo, São Paulo, SP.

Foram enviados à este Comissão de Ética Médica cópia do projeto de pesquisa referido acima, assim como cópia do Processo $n^{\circ}$ 721/2008 /CEP- EEUSP, do Comitê de Ética em Pesquisa da Escola de Enfermagem da Universidade de São Paulo, aprovando a pesquisa do ponto de vista ético-legal.

Esta pesquisa pelos dados apresentados a esta Comissão de Ética Médica encontra-se dentro dos princípios preconizados para a realização de um projeto que envolva seres humanos, em especial em situação de vulnerabilidade. Foram analisados os documentos em anexo, em especial o Termo de Consentimento Livre e Informado que se encontra dentro das recomendações da Resolução 196/96 do CNS, Conselho Nacional de Saúde.

Nada consta que impeça, portanto, sua realização.

Campinas, 12 de junho de 2008.

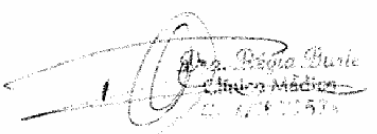

Dra. Régia Maria Burle Figueiredo

Médica Clínica

Presidente da Comissão de Ética Médica do SSCF. 


\title{
Anexo 3: Pedido de Autorização Institucional
}

\author{
Pedido de autorização institucional \\ Universidade de São Paulo \\ Escola de Enfermagem
}

São Paulo, 16 de Junho de 2008.

IIma.sra. Heloísa Novaes de Miranda Amaral Coordenadora do Cândido Escola

Vimos solicitar autorização para Paula Urzúa Taleikis, aluna do programa de Pós-Graduação em Enfermagem da Escola de Enfermagem da Universidade de São Paulo, para realizar a pesquisa intitulada "Saúde Mental e Trabalho: a cooperativa social como estratégia de Reabilitação Psicossocial" (título provisório), que tem por finalidade a obtenção de título acadêmico, nível mestrado.

$\mathrm{Na}$ oportunidade, esclarecemos que, conforme projeto anexo, a pesquisa será realizada com os profissionais técnicos de nível superior e os monitores do Núcleo de Oficinas de Trabalho.

A pesquisa tem por finalidade contribuir com a discussão sobre as cooperativas sociais como estratégias de reabilitação psicossocial no eixo trabalho, dentro do contexto do processo da desinstitucionalização no campo da Reforma Psiquiátrica e da Economia Solidária, refletindo criticamente sobre as iniciativas desenvolvidas em municípios.

Os objetivos são: 1)Analisar os conceitos sobre Reabilitação Psicossocial, Trabalho e Cooperativa Social dos coordenadores e técnicos de um Programa de geração de rendas para usuários de serviços de saúde mental à luz da proposta de desinstitucionalização; 2)Identificar os elementos simples constitutivos da organização do processo de trabalho no Núcleo de Oficinas de Trabalho. 3)Identificar os limites e possibilidades da transformação do projeto de trabalho em cooṕerativas sociais no campo da saúde mental no sentido de constituir-se numa alternativa de trabalho cooperado às pessoas em desvantagem social.

Agradecendo antecipadamente, colocamo-nos à disposição para quaisquer esclarecimentos que forem necessários.

Atenciosamente,

Profa. Dra. Sônia Barros

Professora Doutora do Departamento de enfermagem Materno-Infantil e Psiquiátrica da Escola de Enfermagem da Universidade de São Paulo

P) Ilma.sra. Coordenadora do Cândido Escola

Serviço de Saúde Dr. Cândido Ferreira

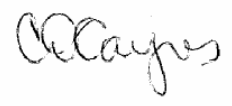




\title{
Anexo 4: Declaração
}

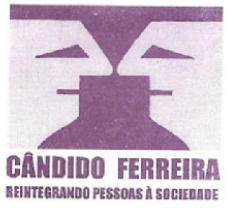

\author{
SERVIÇO DE SAÚDE DR. CÂNDIDO FERREIRA \\ Órgăo de Utilidade Pública: Federal no 48991/60, Estadual 561/61, Municipal 3936/0 e Inscr. Municipal no 100.685-1 \\ Registrado no Serviço Social do Estado de Săo Paulo sob o n $561 / 61$ \\ Rua Antônio Prado, 430 - Vila lório - Fone: PABX: 3758-8600 \\ Cep 13.106-042- Sousas - Campinas - SP \\ http://www.candido.org.br
}

DECLARAÇÃO

Declaro para os devidos fins institucionais que a aluna do Programa de Pós-Graduação da Escola de Enfermagem da Universidade de São Paulo, PAULA URZÚA TALEIKIS, está devidamente autorizada a desenvolver a pesquisa intitulada "Saúde Mental e Trabalho: a cooperativa social como estratégia de Reabilitação Psicossocial" (título provisório) junto ao Núcleo de Oficinas e Trabalho do Serviço de Saúde Dr. Cândido Ferreira, com acompanhamento e supervisão da Profa. Dra. Sônia Barros.

Campinas, 02 de Junho de 2008

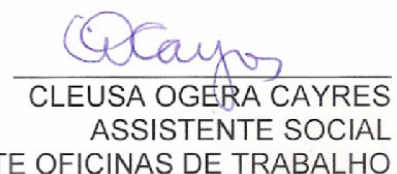


Apêndice 1: Termo de Consentimento Livre e Esclarecido

\section{Termo de Consentimento Livre e Esclarecido}

I. Dados de identificação do sujeito da pesquisa

Nome do entrevistado

II. Dados sobre a pesquisa:

Título da pesquisa: Saúde Mental e Trabalho: a cooperativa social como estratégia de Reabilitação Psicossocial.

Pesquisadora: Paula Urzúa Taleikis

Cargo/Função: Aluna do Programa de Pós-Graduação da Escola de Enfermagem da Universidade de São Paulo - nível mestrado - Área de Concentração Enfermagem psiquiátrica. CRP: 06/62662-5.

Orientadora: Prof ${ }^{\mathrm{a}} \mathrm{Dr}^{\mathrm{a}}$ Sônia Barros

III. Registro das explicações da pesquisadora ao participante da pesquisa:

O presente estudo tem por finalidade contribuir com a discussão sobre as cooperativas sociais como estratégias de reabilitação psicossocial no eixo trabalho, dentro do contexto do processo da desinstitucionalização no campo da Reforma Psiquiátrica e da Economia Solidária no Brasil.

A coleta de dados será realizada por meio de entrevistas semiestruturadas e observação participante. Solicitamos para isso que você responda algumas questões. Sua participação é voluntária e você não é obrigado a participar desse estudo, tendo o direito de sair da pesquisa a qualquer momento que quiser, sem que isto the cause qualquer prejuízo. Você poderá fazer qualquer pergunta acerca do estudo e da sua participação nele, e se tiver alguma dúvida, será esclarecida no decorrer da pesquisa. Os dados referentes a essa pesquisa serão gravados, posteriormente serão transcritos e analisados, porém o seu anonimato será preservado e nem seu nome ou qualquer outro dado que o identifique será revelado, nem mesmo na fase de conclusão e publicação desse estudo. Todos os dados relativos ao estudo serão guardados em local seguro. Se 
necessário, entre em contato com a pesquisadora pelo telefone (11) 92415300 ou por e-mail: paulataleikis@hotmail.com.

IV. Garantias do sujeito da pesquisa: Você tem o direito de a qualquer tempo ter acesso às informações, inclusive para esclarecer eventuais dúvidas. Tem liberdade para retirar em qualquer momento o seu consentimento e deixar de participar da pesquisa, sem que isso the cause qualquer prejuízo. Tem assegurado sua privacidade, seu sigilo e confidencial idade.

V. Consentimento livre e esclarecido

"Declaro que após convenientemente esclarecido pelo pesquisador e ter entendido o que me foi explicado, consinto em participar da presente pesquisa".

São Paulo, de 2008.

Assinatura do sujeito da pesquisa

Assinatura do pesquisador

Assinatura do Orientador

Fone para contato com o Comitê de Ética da Escola de Enfermagem da Universidade de São Paulo: 11- 30617548 
Apêndice 2: Roteiro de Entrevista (Gerente do NOT)

\section{Roteiro da Entrevista}

\section{Quanto à estrutura das Oficinas de Trabalho:}

1. Número de técnicos e monitores, e suas funções;

2. Número de oficineiros e funções;

3. Estrutura física / dimensões

4. Recursos materiais disponíveis

\section{Quanto à organização diária das Oficinas de Trabalho:}

4. Modelo de gestão;

5. Objetivo do serviço;

6. Critérios de admissão e permanência;

7. Coesão e integração do serviço com a comunidade e atores envolvidos;

8. Inserção nos circuitos assistenciais e sociais (parcerias);

9. Relação do serviço com os projetos terapêuticos reabilitativos individuais dos oficineiros (como são formulados);

10. Como se dão as relações de trabalho entre coordenadores, técnicos e oficineiros? Existe algum tipo de hierarquia? Qual o papel do coordenador numa oficina? $\mathrm{E}$ dos técnicos? Monitores? Oficineiros?

11. Qual a relação do NOT com os outros serviços da Rede de Saúde Mental do Município de Campinas?

12. Como o NOT se insere nas políticas públicas do município?

13. Como se organiza o trabalho nas Oficinas? Quem, como e quando se definem as atividades a serem desenvolvidas?

14. Quais são os espaços de discussão sobre o processo de trabalho (avaliação e levantamento de principais problemas e soluções). 
Apêndice 3: Roteiro da Entrevista (coordenadores das oficinas)

\section{Roteiro da Entrevista}

Nome:

Data de Nascimento:

Sexo:

Naturalidade:

Estado Civil:

Escolaridade:

Cursos de atualização:

Função:

Atividades Desenvolvidas:

Tempo de Trabalho no NOT

Experiências Anteriores:

Questões:

a. Descreva uma situação que, do seu ponto de vista, expresse a proposta da oficina.

b. Comente como se dá o processo de inserção e de permanência do usuário na oficina

c. Em sua opinião, quais seriam os limites/dificuldades e possibilidades das oficinas de trabalho?

d. Como você avalia as oficinas de trabalho na transformação da vida dos oficineiros? 